This report was funded by the Bonneville Power Administration (BPA), U.S. Department of Energy, as part of BPA's program to protect, mitigate, and enhance fish and wildlife affected by the development and operation of hydroelectric facilities on the Columbia River and its tributaries. The views in this report are the author's and do not necessarily represent the views of BPA.

For copies of this report, write to:

Bonneville Power Administration

Division 0 F Fish and Wildlife - PJ

P.0. Box 3621

Portland, OR 97208 
IDAHO HABITAT EVALUATION

FOR OFF-SITE MITIGATION RECORD

Annual Report 1988

IDAHO DEPARTMENT OF FISH AND GAKE

\author{
Prepared for \\ Robert Austin, Contracting Officer's Technical Representative \\ U.S. Department of Energy \\ Bonneville Power Administration \\ P.O. Box 3621 \\ Portland, OR 97208 \\ Contract No. DE-A179-84BP13381 \\ Project $83-7$ \\ March 1990
}


REPORT SECTIONS

Page

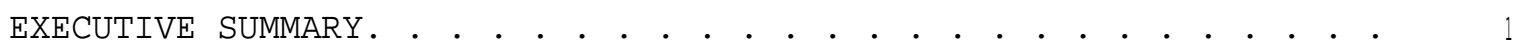

PART I. IDAHO HABITAT EVALUATION FOR OFF-SITE MITIGATION RECORD.

R.J. Scully, E.J Leitzinger, and C.E.Petrosky . . • • . . I-l

PART II. INTENSIVE EVALUATION AND MONITORING OF CHINOOK SALMON

AND STEELHEAD TROUT PRODUCTION. CROOKED RIVER AND UPPER

SALMON RIVER SITES. R.B. Kiefer and K. Forster . . . . . II-1 


\section{EXECUTIVE SURMARY}

Project 83-7 was established under the Northwest Power Planning Council's 1982 Fish and Wildlife Program, Measure 704 (d) (1) to monitor natural production of anadromous fish, evaluate BPA habitat improvement projects and develop a credit record for off-site mitigation projects in Idaho.

The Idaho Department of Fish and Game (IDFG) has been monitoring and evaluating existing and proposed habitat improvement projects for steelhead and chinook in the Clearwater and Salmon subbasins since 1984. Projects included in the monitoring are funded by, or proposed for funding by, the Bonneville Power Administration (BPA) under the Northwest Power Planning Act as off-site mitigation for downstream hydropower development on the Snake and Columbia Rivers. This monitoring project is also funded under the same Authority.

A mitigation record is being developed to use actual and potential increases in smolt production as the best measures of benefit from a habitat improvement project. Determination of full benefit from a project depends on presence of adequate numbers of fish to document actual increases in fish production. The depressed nature of upriver anadromous stocks has precluded attainment of full benefit of any habitat project in Idaho. Partial benefit is credited to the mitigation record in the interim period of run restoration.

Project 83-7 is divided into two subprojects: general and intensive monitoring. Primary objectives of the general monitoring subproject (Scully, et al. 1990) are to determine natural production increases due to habitat improvement projects in terms of parr production and to determine natural production status and trends in Idaho. The second objective is accomplished by combining parr density data from monitoring and evaluation of BPA habitat projects and from other IDFG management and research activities. The primary objective of the intensive monitoring subproject (Kiefer and Forster 1990) is to determine the relationships between spawning escapement, parr production, and smolt production in two Idaho streams: the upper Salmon River and Crooked River. Results of the intensive monitoring will be used to estimate mitigation benefits in terms of smolt production and to interpret natural production monitoring in Idaho.

\section{Project Benefits}

Project benefits to date, estimated in terms of parr produced, averaged 122,874 chinook and 14,618 steelhead from 1986 to 1988 (Summary Tables 1 and 2). None of the habitat projects have yet realized their full potential due to low escapements and a time lag in physical habitat and population responses. Barrier removal, off channel development, and instream structure and sediment reduction projects contributed 70, 4, 22 and $4 \%$ of the total parr benefits, respectively. A number of uncertainties exist regarding effectiveness of instream structures. Sediment reduction projects are still in progress, and anticipated benefits are yet to accrue. 
Summary Table 1. Total abundance of steelhead parr (ages-lt and $-2+)$ attributed to benefits of implemented projects, 1985-1988.

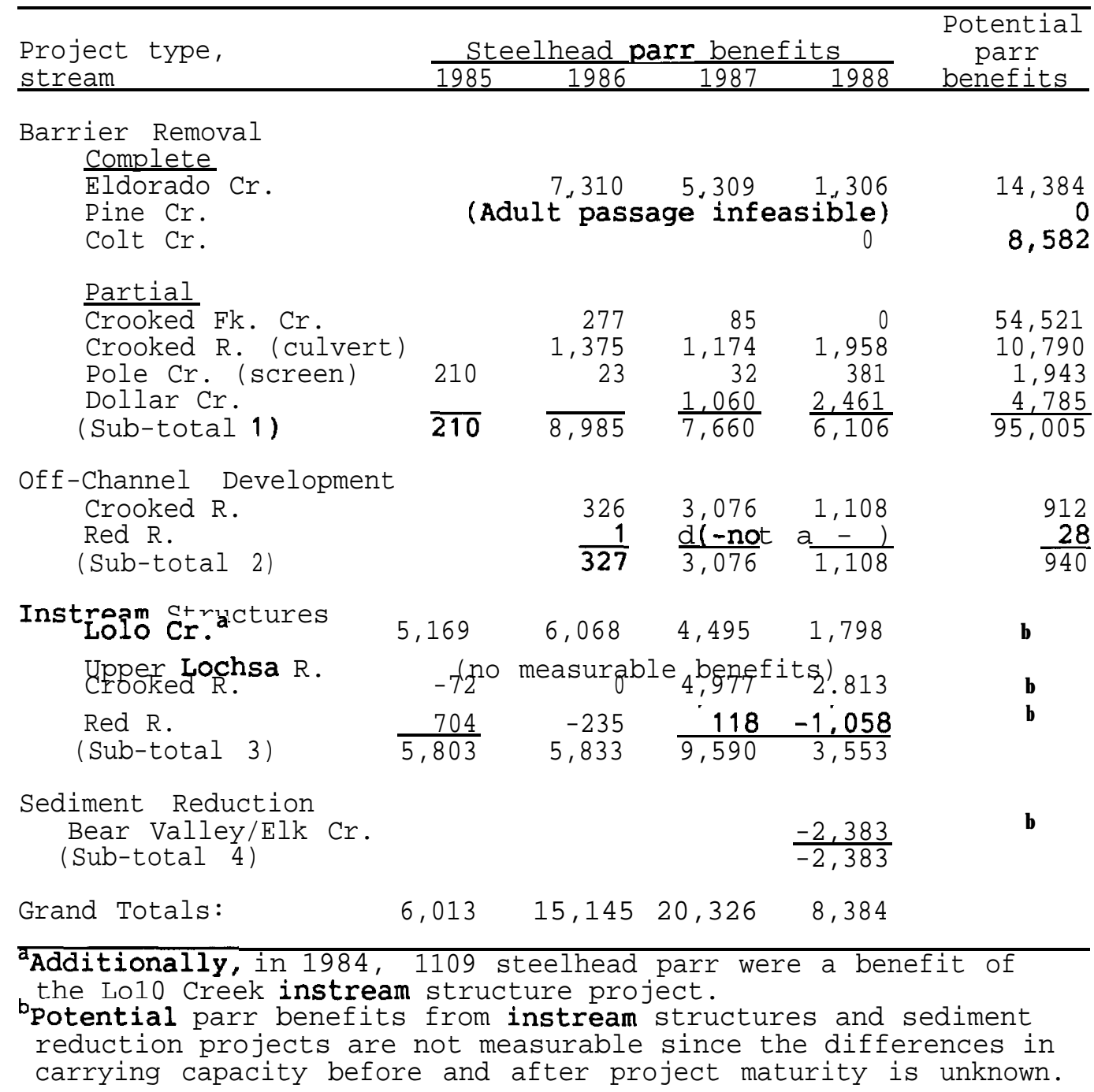


Summary Table 2. Total abundance of chinook parr (age-0+)

attributed to benefits of implemented projects, 1985-1988.

\begin{tabular}{|c|c|c|c|c|c|}
\hline $\begin{array}{l}\text { Project type, } \\
\text { stream }\end{array}$ & $\frac{\mathrm{Ch}}{1985}$ & $\frac{\text { nook parr }}{1986}$ & $\frac{\text { benefits }}{1987}$ & 1988 & $\begin{array}{l}\text { Potential } \\
\text { parr } \\
\text { benefits }\end{array}$ \\
\hline \multirow{2}{*}{$\begin{array}{l}\text { Barrier Removal } \\
\text { Complete } \\
\text { Eldorado } \mathrm{Cr} . \\
\text { Crooked } \mathrm{Fk} . \mathrm{Cr} . \\
\text { Johnson } \mathrm{Cr} . \\
\text { Boulder } \mathrm{Cr} . \\
\text { Meadow } \mathrm{Cr} . \\
\text { Knapp Cr. } \\
\text { Partial } \\
\text { Crooked R. . } \\
\text { (culvert) } \\
\text { Pole Cr. (screen) } \\
\text { Dollar Cr. } \\
\text { (Sub-total 1) }\end{array}$} & 7,206 & $\begin{array}{l}30,206 \\
17,600 \\
23,711 \\
28,112\end{array}$ & $\begin{array}{r}13,328 \\
32,600 \\
17,700 \\
0\end{array}$ & $\begin{array}{r}5,936 \\
17,700 \\
52,086 \\
1,560 \\
15,000 \\
63\end{array}$ & $\begin{array}{r}110,478 \\
57,248 \\
294,750 \\
82,504 \\
39,036 \\
84,040\end{array}$ \\
\hline & $\begin{array}{r}5,351 \\
0 \\
12,557\end{array}$ & $\begin{array}{r}3,707 \\
0\end{array}$ & $\begin{array}{r}740 \\
0 \\
64,370\end{array}$ & $\begin{array}{r}7,061 \\
8 \\
38 \\
99,452\end{array}$ & $\begin{array}{r}18,562 \\
14,962 \\
7,255 \\
708,835\end{array}$ \\
\hline $\begin{array}{l}\text { Off-Channel Developme } \\
\text { Crooked R. } \\
\text { Red R. } \\
\text { (Sub-total }\end{array}$ & & $\begin{array}{l}4,119 \\
215 \\
4,339\end{array}$ & $\begin{array}{l}209 \\
(- \text { no } \\
209\end{array}$ & $\begin{array}{r}5,865 \\
\text { data-) } \\
5,865\end{array}$ & $\begin{array}{r}37,123 \\
\frac{216}{37,339}\end{array}$ \\
\hline Instrâm Structures & 10,788 & $-23,823$ & 29,891 & 8,990 & a \\
\hline $\begin{array}{l}\text { Upper I I chsa R. } \\
\text { Red R. }\end{array}$ & $\begin{array}{c}-5,121 \text { ho } \\
9,291\end{array}$ & $\begin{array}{c}\text { measurabl } \\
9,526\end{array}$ & $\begin{array}{c}\text { le bepgfit } \\
19,052\end{array}$ & $\begin{array}{r}6,852 \\
21,874\end{array}$ & a \\
\hline$($ Sub-total 3) & $\overline{14,958}$ & $-1 \overline{5,183}$ & $\overline{51,035}$ & $\overline{37,716}$ & \\
\hline $\begin{array}{c}\text { Sediment Reduction } \\
\text { Bear Valley/Elk } \\
\text { (Sub-total 4) }\end{array}$ & & & & $\frac{17,489}{17,489}$ & a \\
\hline Grand Totals: & 27,515 & 92,487 & 115,614 & 160,522 & \\
\hline
\end{tabular}

apotential parr benefits from instream structures and sediment reduction projects is not measurable since the difference in carrying capacity before and after project maturation is unknown. 
Benefits of habitat improvement will depend largely on improved main stem flow and passage conditions. Under poor main stem flow conditions, many chinook populations could face extinction with or without habitat improvement. Under marginal flow conditions, improved egg-to-smolt survival from habitat improvement, such as sediment reduction, could make the difference between extinction and a viable, depressed population. Under good flow conditions, habitat projects that increase egg-to-smolt survival or carrying capacity will contribute to productivity and harvest potential of wild and natural populations.

\section{General Monitoring}

Major findings from parr density monitoring are:

I. Chinook parr densities were highest in C channel (meandered), and steelhead parr densities were highest in B channel (confined) stream sections.

2. Carrying capacity was estimated for chinook parr in excellent $C$ channel habitat to be $108 / 100 \mathrm{~m}^{2}$, and for steelhead parr in excellent $B$ channel habitat to be $20 / 100 \mathrm{~m}^{2}$.

3. Wild chinook parr densities and estimated egg-to-parr survival rates in Salmon River tributaries were significantly reduced at high sediment levels.

4. Differential supplementation levels in other streams masked sediment effects on chinook parr densities.

5. The relationship between sediment and steelhead parr densities was weak because of steelhead preference for high gradient, B channel streams which tend to flush sediments.

6. Chinook and steelhead parr densities were 13.5 and 9.3 times higher in control streams not grazed by cattle than in the heavily grazed, highly sedimented Bear Valley/Elk Creek drainage, respectively.

7. During 1985-88 chinook and steelhead parr densities averaged 15.3 and $27.2 \%$ of carrying capacity, respectively, and demonstrated no annual trend.

8. During 1985-88 the percent of carrying capacity for chinook parr averaged 11.8 in wild (indigenous) production areas and 17.4 in natural (hatchery influenced) production areas.

9. Reproduction curves for chinook parr and redd densities indicated that escapements were well below detectable density dependent effects. 
10. During 1985-88, the percent of carrying capacity for steelhead parr in four classes wild A-run, wild B-run, natural A-run, and natural B-run, were: $72.9,11.7,27.6$, and 37.1 , respectively.

11. Chinook fry stocked into vacant habitat had a 20\% survival rate to the parr stage (range 11-33\%), and generally survived better in high quality streams.

\section{Intensive Monitoring}

Intensive studies were begun in 1987 in the upper Salmon River and Crooked River (South Fork Clearwater River tributary) to determine the relationships between spawning escapement, parr production, and smolt production. The studies incorporate data from general monitoring and rely on weirs to trap adults and scoop traps to trap juvenile migrants. PIT tags (Passive Integrated Transponder) are being inserted into juvenile fish to determine parr-to-smolt survival rates. They also provide other basic information, such as smolt migration timing, effects of flow and passage conditions on smolt survival, upstream migrational timing, etc. PIT tags can provide a major key to extrapolating survival rates between fish populations in streams with different stocks, habitat types, instream flow regime, and sediment levels.

This was the first year (1988) in the upper Salmon River (USR) that a brood year (BY) of spring chinook was studied from spawning escapement (1986) to the parr stage (1987) and, in part, to the smolt stage (spring 1988). For USR Arun steelhead, the first estimates for the full cycle of tributary rearing will be made after the 1989 smolt migration. Construction delays for the Crooked River (CR) adult trap and weir have precluded direct counts of spawning escapements of spring chinook and B-run steelhead. The first estimates for CR chinook and steelhead parr-to-smolt survival will be made after the 1989 and 1990 smolt migrations, respectively.

Major findings of the intensive monitoring study are:

1. Estimated egg-to-parr survival rates for USR chinook in BY 1986-87 averaged 5.2\%, lower than in similar streams due in part to low summer flows in 198788 and an apparently large, unquantified emigration of fry after emergence.

2. USR chinook egg-to-parr survival varied by supplementation method with adult, fry, and eyed-egg outplants averaging 32\%, 16\%, and $0.4 \%$, respectively.

3. Egg deposition and total parr abundance have been estimated for USR steelhead, however better definition of age and size of parr is necessary to define egg-to-parr survival by brood year.

4. Estimated egg-to-parr survival rate for CR chinook in BY 1987 was 19-28\%, depending on assumptions used to partition survival of supplemented fry from natural fry. 
5. Lack of the adult weir and valid steelhead redd counts precluded estimation of egg-to-parr survival for CR steelhead through 1988.

6. The magnitude of fall outmigration was higher in the USR than in CR for chinook and steelhead. Fall 1988 outmigrants accounted for $64 \%$ and $21 \%$ of the chinook parr population and 48\% and 3\% of the steelhead parr population in USR and $\mathrm{CR}$, respectively.

7. PIT-tagged chinook and steelhead from the USR were detected at Lower Granite Dam at rates of $4.0 \%$ and $4.1 \%$, respectively, in spring 1988 . The first detections of PIT-tagged CR fish will occur in spring 1989.

8. Parr-to-smolt mortality for chinook and steelhead parr PIT-tagged above the S45 diversion on the USR was four and three times higher, respectively, than mortality of parr tagged below the diversion because of dewatering in late August and september when the parr emigrate from summer rearing areas.

9. Off-channel ponds connected to $\mathrm{CR}$ through BPA habitat improvement reared high densities of chinook parr, and the strategy was recommended for rehabilitation of other streams degraded by dredge mining.

10. The $\mathrm{S} 45$ and Alturas Lake Creek diversions blocked the majority of adult chinook from reaching the low gradient headwater streams where we have observed high egg-to-parr survival, 


\author{
Part I \\ Subproject I \\ IDAHO HABITAT EVALUATION \\ FOR OFF-SITE MITIGATION RECORD
}

Annual Report 1988

\author{
Prepared by \\ R.J. Scully, Senior Fisheries Research Biologist \\ E.J. Leitzinger, Fisheries Technician \\ and \\ C.E. Petrosky, Staff Biologist \\ IDAHO DEPARTMENT OF FISH AND GAME
}

Prepared for

Robert Austin, Contracting Officer's Technical Representative U.S. Department of Energy

Bonneville Power Administration

Division of Fish and Wildlife

P.0. Box 3621

Portland, OR 97208

Contract No. DE-A179-84BP13381

Project $83-7$

November 1989 
Physical Habitat . . . . . . . . . . . . . . . . . I-3

Parr Density Monitoring. • . • . . . . . . . . . . • I-6

Anadromous Fish Introduction . . . . . . . . . . . . I I-8

Steelhead Rearing Potential . . . . . . . . . . . . I I-8

Chinook Rearing Potential . . . . . . . . . . . . . I-8

Chinook Reproduction Curves . . . . . . . . . . . . . I-IO

Chinook Egg-to-Parr Survival . . . . . . . . . . . . I-10

Partial Project Benefits . . . . . . . . . . . . . • I-10

Data Base Management and Statistical Analyses . • • • . I-13

RESULTS $\quad$ •

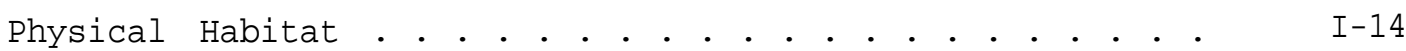

Substrate Sand and Parr Densities . . . . . . . . . . . I-18

Chinook Parr . . . . . . . . . . . . . . . . . . I-18

Steelhead Parr . . . . . . . . . . . . . . . I I-19

Bear Valley/Elk Creek verses Control Streams . . . I-19

Parr Density Monitoring . . . . . . . . . . . . . • I-22

Steelhead Parr Monitoring . . . . . . . . . . • I-22

Steelhead Classification . . . . . . . . . I I-22

Drainage and Group Categories . . . . . . . I-28

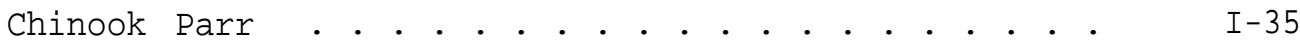

Wild verses Natural Production . . . . . . . I-35

Class and Drainage Cells . . . . . . . . . I-39

Parr Densities in Main Stem Corridors . . . . . . . I I-44

Steelhead Rearing Potential . . . . . . . . . . . . . . I-44

Chinook Rearing Potential . . . . . . . . . . . . . . I-47

Chinook Reproduction Curves . . . . . . . . . . . . . I-47

Chinook Egg-to-Parr Survival . . . . . . . . . . . . . I-55

Partial Project Benefits . . . . . . . . . . . . . . I I-59

Expected Benefits from Flow/Passage and Habitat

Improvement . . . . . . . . . . . . . . . I I-59

Crooked River, Red River, and Lo10 Creek . . . I-65

DISCUSSION • • • • • • • • • • • • • • • • • • • • • • • • • •

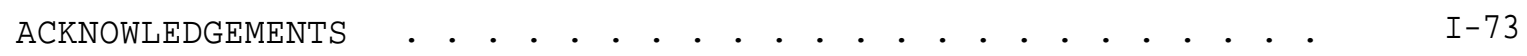

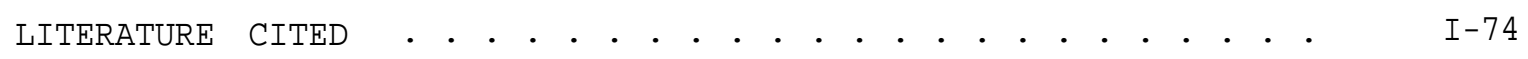

APPENDIXA . . . . . . . . . . . . . . . . . . . . . . . . . . . . . . . . . . 
TABLE OF CONTENTS (Cont.)

Page

APPENDIXB

APPENDIXC

\section{IIST OF TABLES}

Table 1. Schedule of BPA project implementation (I) and evaluation activities ( $\mathrm{P}=$ pretreatment evaluation, $\mathrm{M}=$ monitoring, and $\mathrm{E}=$ post-treatment evaluation) in Idaho, 1983-1988. . . . . . . . . . . . . . . I-4

Table 2. Number of sections where steelhead and chinook parr were monitored by BPA Project 83-7 and the IDFG management and research programs from 1984 through 1988

Table 3. Chinook fry stocking summary for rearing-potential investigations, upper Lochsa River tributaries, 1988 . . . . . . . . . . . . . . . .

Table 4. Spawning ground survey reaches and parr monitoring sections of the Salmon River and tributaries used to develop chinook reproduction curves, brood years

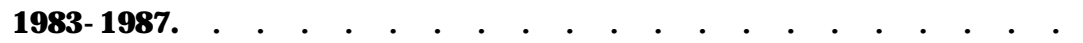

Table 5. Mean and maximum chinook density by sediment class for $C$ channel monitoring sections statewide and in the Middle Fork Salmon River (MFSR) drainage, 1984.88..

Table 6. Mean and maximum ages-1+ and $-2+$ steelhead parr density by sediment class for B channel monitoring sections statewide and in the Middle Fork Salmon River (MFSR) drainage, 1984-88 . . . . . . . .

Table 7. Annual means, standard errors and sample sizes for densities and percent carrying capacities (PCC) of ages-1+ and -2+ steelhead parr combined and for densities of age-l+ steelhead alone. . . . . . . . 
Table 8. Annual mean densities (number/100 $\mathrm{m}^{2}$ ) of five classes of age-1+ and $-2+$ steelhead parr in $B$ channels from 1985 through 1988. • . , . . . . . .

Table 9. Annual mean densities of wild A-run and wild $B$-run steelhead parr for all (both $B$ and $C$ channels) monitoring sections and the annual ratio of wild A-run to wild B-run densities from 1985 to1988. . . . . . . . . . . . . . . . . . .

Table 10. Results of one-way analyses of variance on age-l+ wild steelhead mean densities for all wild A-run and B-run parr and for those groups in B channels only • • • • • • • • • • • • • • • • • • • • • • • •

Table 11. Mean densities (number/100 $\mathrm{m}^{2}$ ) and sample sizes (in parentheses) of age-1+ and $-2+$ steelhead parr in 12 cells encompassing Idaho's anadromous fish waters, in B channels. . . . . . . . . . . . . . . . .

Table 12. Mean annual densities (number/100 $\mathrm{m}^{2}$ ) of age-l+ steelhead parr in B channels from 1985 through 1988. There were highly significant differences between mean cell densities within each year . • .

Table 13. Streams, stratum-section locations, channel types, years sampled and densities recorded for ages-1+ and -2+ steelhead parr for samples where densities have exceeded 75\% of rated carrying capacities in streams with B-run steelhead stocks. . . . . . .

Table 14. Number of monitoring sections for four classes of chinook salmon parr. . . . . . . . . . . . .

Table 15. Mean annual chinook densities (number/100 $\mathrm{m}^{2}$ ) and percents of carrying capacity for all monitoring sections and separately for $B$ and $C$ channel sections. Probabilities of mean values being significantly different between years and between classes are included . . . . . . . . . . . . . .

Table 16. Mean chinook parr densities (number/100 $\mathrm{m}^{2}$ ) and percent carrying capacities (PCC) for chinook parr in 13 class/drainage cells, from 1985 through 1988. Sample sizes are in parentheses . . . . . . 
Table 17. Mean annual densities of age-0+ chinook parr in individual drainage cells from 1985 through 1988 in

C channels . . . . . . . . . . . . . . .

Table 18. Mean chinook and steelhead densities (number/100 $\mathrm{m}^{2}$ )

from 1985 to 1988 in corridor sections of three

main stem rivers and in monitoring sections of the

same drainages... . . . . . . . . . . . . . . .

Table 19. Mean annual densities of chinook and steelhead parr in main stem corridor snorkeling sites of three major Idaho drainages. . . . . . . . . . . . .

Table 20. Monitoring sections where densities (number/100 $\mathrm{m}^{2}$ ) of steelhead parr (ages-1+ and $-2+$ ) exceeded 75\% of rated carrying capacity in $\mathrm{B}$ and $\mathrm{C}$ channels. . . . .

Table 21. Mean density and percent of carrying capacity (PCC) for steelhead and chinook parr in samples where density exceeded $75 \%$ of rated carrying capacity (CC)

Table 22. Monitoring sections where densities (number/100 $\mathrm{m}^{2}$ ) of chinook parr (age-0+) exceeded 75\% of rated carrying capacity in $\mathrm{B}$ and $\mathrm{C}$ channels. . . . . . .

Table 23. Regression coefficients, significance levels (prob.) and coefficients of determinations $\left(x^{2}\right)$ for linear and Beverton-Holt hyperbolic reproduction curves for parr density samples where percent surface substrate sand was $\leq 303,30-40 \%$ and $>40 \%$. The relations are between the parental redd.s/ha (P) and the recruited parr $/ 100 \mathrm{~m}^{2}(\mathrm{R})$. . . . . . . .

Table 24. Mid August parr survival from mid May fry releases of chinook salmon into seven Idaho streams from 1986 to1988 . . . . . . . . . . . . . .

Table 25. Summary of chinook parr density (number/100 $\mathrm{m}^{2}$ ) 13 to 15 weeks after stocking near four sites, upper Lochsa River, August 1988. . . . . . . . . . . . . .

Table 26. Total abundance and fry-to-parr survival estimates for age-0 chinook, at four stocking sites, upper Lochsa River, August 1988. . . . . . . . . . . . 


\section{LIST OF TABLES (Cont.)}

\section{$\underline{\text { Paqe }}$}

Table 27. 1988 mid August chinook parr survival estimates from the September 1987 eyed-egg plants and adult releases . . . . . . . . . . . . . . .

Table 28. Wild/natural chinook egg to parr survival estimates by $\div$ sand categories. The analysis assumes a fecundity of 5,900 eggs/female and 1.5 redds/female . . . . . . . . . . . . . . . .

Table 29. Total abundance of steelhead parr (ages-1+ and -2+) attributed to benefits of implemented projects, 1985-1988. (See Appendix B for calculations and assumptions)

Table 30. Total abundance of chinook parr (age-0+) attributed to benefits of implemented projects, 1985-1988. (See Appendix B for calculations and assumptions) . . . .

Table 31. Project benefits in terms of adult spawners and terminal harvest from projects that increase eggto-smolt survival. Benefits were estimated from subbasin planning, existing monitoring data, and different smolt-to-adult return rates (SAR) for various main stem flow/passage conditions. . . . .

Table 32. Project benefits in terms of adult spawners and terminal harvest from projects that add habitat or increase carrying capacity. Benefits were estimated from subbasin planning, existing monitoring data, and different smolt-to-adult return rates (SAR) for various main stem flow/passage conditions. . . . .

Table 33. Two way ANOVA results for the instream structure evaluations on Crooked River, Red River, Lolo Creek separately and repeated measures analysis on all streams combined, 1985-1988. . . . . . . . . . .

Table 34. Existing and potential weir site for monitoring passage of adult anadromous fish in Idaho. . . . . . 


\section{LIST OF FIGURES}

$\underline{\text { Paqe }}$

Figure 1. Idaho's anadromous fish waters showing major drainages of the Clearwater, Salmon and Snake River subbasins. . . . . . . . . . . . . . . . .

Figure 2. Hypothetical schedule for estimating partial and full benefits of a project (in terms of parr) from monitoring and evaluation programs. . . . . . .

Figure 3. Chinook fry stocking sites, upper Lochsa River

tributaries . . . . . . . . . . . . . ,

Figure 4. Mean width, depth and gradient for $B$ and $C$ channels in monitoring sections . . . . . . . . . . . . .

Figure 5. Percentages of the different habitat types in B and C channel monitoring sections . . . . . . . .

Figure 6. Percentages of the different substrate categories in $\mathrm{B}$ and $\mathrm{C}$ channel monitoring sections . . . . . .

Figure 7. Average annual densities of chinook and steelhead parr in the heavily sedimented Bear Valley/Elk Creek drainage and Middle Fork Salmon River control streams . . . . . . . . . . . . .

Figure 8. An annual comparison of mean parr densities of both chinook (age-O+) and steelhead (ages-1+ and -2+) in $B$ and C channels. . . . . . . . . . . . .

Figure 9. Present distribution of wild A-run and B-run steelhead production areas in Idaho. . . . . . .

Figure 10. Annual density ratios of wild A-run:wild B-run steelhead by channel type, for ages-1+ and $-2+$, 1985-1988

Figure 11. Mean annual densities of age-1+ and $-2+$ wild steelhead parr in two A-run areas and three B-run areas, in B channels, 1984-1988... . . . . . . . . .

Figure 12. Mean annual densities of age-1+ and $-2+$ natural steelhead parr in three $A$-run areas and three B-run areas, in B channels, 1984-1988 . . . . . .

Figure 13. Present distribution of wild chinook production areas in Idaho. 
Figure 14. Mean annual densities of age-O+ chinook parr in C channels in four wild chinook production areas, 1984-1988 . . . . . . . . . . . . . . .

Figure 15. Mean annual densities of age-o+ chinook parr in four natural chinook production areas, 1984-1988 . • . .

Figure 16. Linear and Beverton-Holt regression lines for the density of chinook parr expected as redds per hectare increase. The large arrow represents our best estimate of parr carrying capacity. Scatter points represent redds/ha:parr/100 $\mathrm{m}^{2}$ data from the upper and Middle Fork Salmon River for brood years 1983-1987, for streams with $=<30 \%$ substrate surface sand. . . . . . . . . . . . . . . . .

Figure 17. Mean densities in control (C) and treatment (T) sections (and 95\% confidence limits) of chinook and steelhead relative to instream structures placed in Crooked River. Values are averages for 1985 through 1988. • . . . . . . . . . . . . . . . . .

Figure 18. Mean densities in control (C) and treatment (T) sections (and 95\% confidence limits) of chinook and steelhead relative to instream structures placed in Lolo Creek. Values are averages for 1985 through 1988. . . . . . . . . . . . . . . .

Figure 19. Mean densities in control (C) and treatment (T) sections (and 95\% confidence limits) of chinook and steelhead relative to instream structures placed in Red River. Values are averages for 1985 through

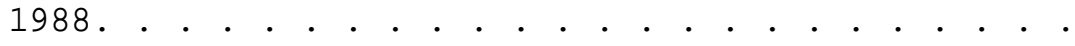


Appendix A-1. Monitoring section names and EPA stream reach locations, channel types ( $\mathrm{B}$ or $\mathrm{C}$ ), steelhead classification (wild or natural, A-run or B-run), chinook classification (wild or natural, springs or summers) and if chinook are monitored there. . . . . . . . . . . .

Appendix A-2. Main stem rivers and sections where corridor snorkeling is done. EPA reach and steelhead and chinook classifications are listed. . . . . .

Appendix A-3. Summary of hatchery chinook releases (in thousands) into natural production areas for BPA habitat project and monitoring streams, 1984-1988................ .

Appendix A-4. Summary of hatchery steelhead releases (in thousands) into natural production areas for BPA habitat project and monitoring streams, 1984-1988. . . . . . . . . . . . . . .

Appendix B-1. Proposed definition of mitigation benefits for implemented projects on Lolo Creek. . . . . .

Appendix B-2. Proposed definition of mitigation benefits for implemented projects on Eldorado Creek. . . .

Appendix B-3. Proposed definition of mitigation benefits for implemented projects on upper Lochsa River. .

Appendix B-4. Proposed definition of mitigation benefits for implemented projects on Crook Fork Creek. . .

Appendix B-5. Proposed definition of mitigation benefits for implemented projects on Colt Creek. . . . . .

Appendix B-6. Proposed definition of mitigation benefits for implemented projects on Crooked River . . . .

Appendix B-7. Proposed definition of mitigation benefits for implemented projects on Red River . . . . . .

Appendix B-8. Proposed definition of mitigation benefits for implemented projects on Pine Creek. . . . . . 
Appendix B-9. Proposed definition of mitigation benefits for implemented projects on Pole River. . . . . .

Appendix B-10. Proposed definition of mitigation benefits for implemented projects on Bear Valley and Elk

Creeks. . . . . . . . . . . . . . .

Appendix B-1 1. Proposed definition of mitigation benefits for implemented projects on Knapp Creek . . . . .

Appendix B-12. Proposed definition of mitigation benefits for implemented projects on Johnson Creek . . . . .

Appendix B-13. Proposed definition of mitigation benefits for implemented projects on Dollar Creek. . . . .

Appendix B-14. Proposed definition of mitigation benefits for implemented projects on Boulder Creek . . . . .

Appendix B-15. Proposed definition of mitigation benefits for implemented projects on Meadow Creek. . . . .

Appendix B-16. Proposed definition of mitigation benefits for implemented projects on Valley Creek. . . . . .

Appendix C. Percent surface sand and density of wild chinook and steelhead parr in established monitoring sections in the heavily sedimented Bear Valley/Elk Creek drainage and control streams in the Middle Fork Salmon River drainage, 1985-1988

Appendix

Figure 1. Ratio of mean annual chinook parr density in Bear Valley/Elk Creek drainage relative to chinook Parr densities in Middle Fork Salmon River control st reams............... 


\section{INTRODUCTION}

The Idaho Department of Fish and Game (IDFG) has been monitoring and evaluating proposed and existing habitat improvement projects for rainbowsteelhead trout oncorhvnchus mykiss, hereafter called steelhead, and chinook salmon Oncorhvnchus tshawytscha, hereafter called chinook, in the clearwater and Salmon River drainages (Figure 1) for the past five years. Projects included in the evaluation are funded by or proposed for funding by the Bonneville Power Administration (BPA) (1985) under the Northwest Power Planning Act as off-site mitigation for downstream hydropower development on the Snake and Columbia Rivers. This evaluation project is also funded under the same authority (Fish and Wildlife Program, Northwest Power Planning Council).

A mitigation record is being developed to use increased smolt production at full seeding as the best measure of benefit from a habitat enhancement project. Determination of full benefit from a project depends on completion or maturation of the project and presence of adequate numbers of fish to document actual increases in fish production. The depressed status of upriver anadromous stocks have precluded measuring full benefits of any habitat project in Idaho. Partial benefit is credited to the mitigation record in the interim period of run restoration.

According to the BPA Work Plan (BPA 1985), project implementors have the major responsibility for measuring physical habitat and estimating habitat change. To date, Idaho habitat projects have been implemented primarily by the U.S. Forest Service (USFS). The Shoshone-Bannock Tribes (SBT) have sponsored three projects (Bear Valley Mine, Yankee Fork, and the proposed East Fork Salmon River projects). IDFG implemented two barrier removal projects (Johnson Creek and Boulder Creek) that the USFS was unable to sponsor at that time. The role of IDFG in physical habitat monitoring is primarily to link habitat quality or habitat change to changes in actual and potential fish production.

Estimation of anadromous fish response to BPA habitat projects in Idaho is generally the responsibility of IDFG (BPA 1985). However, the SBT have primary responsibility for developing the mitigation record for the three projects that they have sponsored.

Approaches to monitor habitat projects and document a record of credit were developed in 1984-1985 (Petrosky and Holubetz 1985, 1986). The IDFG evaluation approach consists of three basic, integrated levels: parr density monitoring, parr standing crop evaluations, and estimation of survival rates between major fresh water life stages of chinook and steelhead. The latter level will be referred to as "intensive studies." Annual general monitoring of anadromous fish densities in a small number of sections for each project will be used to follow population trends and define seeding levels. For most projects, standing crop estimates of parr will be used to estimate smolt production based on survival rates from parr-to-smolt stages. Intensive studies (Kiefer and Forster 1990) will determine parr-to-smolt survival rates and provide other basic biological information that is needed for evaluation of the Fish and Wildlife Program. 


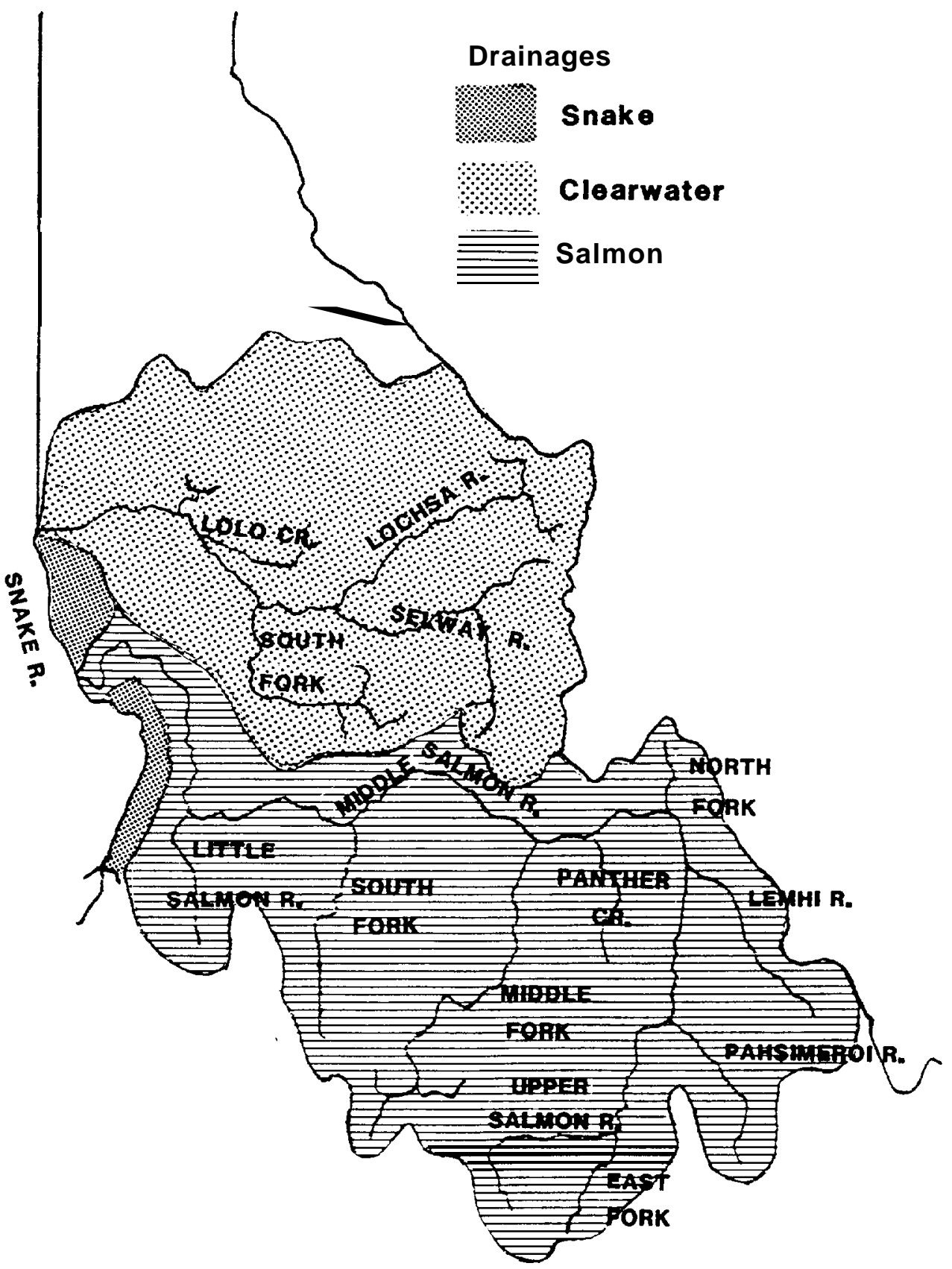

Figure 1. Idaho's anadromous fish waters showing major drainages of the Clearwater, Salmon, and Snake River subbasins. 
A physical habitat and parr density data base has been developed for BPA habitat projects in Idaho. The data will be integrated among the three evaluation levels. The schedule of BPA habitat project implementation and IDFG general monitoring-evaluation activities from 1983-1988 is presented in Table 1. A complete mitigation record will be made when three conditions are met: I) the habitat project is completed or at full maturation; 2) the fish population affected is observed at full seeding, or a full seeding level has been determined for the affected habitat type; and 3) the appropriate survival rates from summer parr stage to smolt stage have been determined from the intensive studies.

After a habitat enhancement project has been implemented and prior to the time that the aforementioned conditions have been met, IDFG will construct a partial mitigation record based on estimated increases in parr production. At a later time, the interim parr responses can be converted to estimated smolt yields. Monitoring data will be essential to establish trends and estimate partial benefits during the years that project evaluations are not conducted (Figure 2).

In 1988, the general monitoring and evaluation project focused on five areas: 1) general density monitoring; 2) anadromous fish introductions above treated passage barriers; 3) investigations into rearing potential for chinook and steelhead; 4) comparisons of percent carrying capacities of A- and B-ty'pe steelhead parr; and 5) comparisons of percent carrying capacities between wi.ld and natural stocks of both steelhead and chinook.

\section{METHODS}

\section{Physical Habitat}

The Idaho Habitat Evaluation for Off-Site Mitigation Record project has been monitoring parr densities in stream sections within the Clearwater and Salmon River drainages since 1984. Additionally, the regional fisheries programs have been monitoring parr densities in stream sections in coordination with the former project, such that parr densities are being monitored in all major anadromous fish production areas of the state. The number of sections monitored annually since 1984 is shown in Table 2.

Monitoring sections provide an annual index of anadromous fish abundance in different habitat types and drainages. The section boundaries were defined at breaks between habitat types; most sections included at least one riffle-pool sequence, and were approximately $100 \mathrm{~m}$ long. Streams, project strata, and sections were cross-referenced to the Environmental Protection Agency (EPA) reach numbering system.

Physical habitat variables were standardized and measured at least one time since 1984 in each established density monitoring section and in most other sections used in habitat project evaluations. The physical habitat variables were not measured every year in each section due to time constraints (parr 
Table 1. Schedule of BPA project implementation (I) and evaluation activities ( $\mathbf{P}=$ pretreatment evaluation, $\mathrm{M}=$ monitoring, and $\mathrm{E}=$ post-treatment evaluation) in Idaho, 1983-1988.

\begin{tabular}{|c|c|c|c|c|c|c|c|}
\hline Project & $\begin{array}{l}\text { Project } \\
\text { type }\end{array}$ & 1983 & 1984 & 1985 & 1986 & 1987 & 1988 \\
\hline Lolo Creek & IS & I & $I, P, E$ & $\mathrm{E}$ & $\mathrm{M}$ & M & M \\
\hline Eldorado Creek & $\mathrm{PA}$ & & $\mathrm{I}, \mathrm{P}$ & $I, M$ & $\mathrm{E}$ & M & $\mathrm{M}$ \\
\hline Upper Lochsa River & IS & I & $\mathbf{I}, \mathbf{E}$ & $\mathrm{M}$ & M & M & M \\
\hline Crooked Fork Creek & $\mathrm{PA}$ & & $\mathrm{I}, \mathrm{P}$ & $I, P$ & E & $\mathrm{E}$ & $\mathrm{E}$ \\
\hline Colt Creek & $\mathrm{PA}$ & & & & I & $\mathrm{M}$ & $\mathrm{M}$ \\
\hline Crooked River & $\mathrm{PA}$ & & $I, P$ & $\mathrm{M}$ & $\mathrm{E}$ & M & $\mathrm{M}$ \\
\hline & $\begin{array}{l}\text { IS } \\
\mathrm{BC}\end{array}$ & & $\mathrm{I}_{\mathrm{P}} \mathrm{P}$ & $I_{I}, P, M$ & $\begin{array}{l}E \\
E\end{array}$ & $\begin{array}{l}M \\
M\end{array}$ & $\begin{array}{l}\text { M } \\
M\end{array}$ \\
\hline & OC & & $I, M$ & $I, M$ & $\mathrm{I}, \mathrm{E}$ & $I, M$ & $I, M$ \\
\hline Red River & $\mathrm{BC}$ & I & $I, M$ & $\mathrm{M}$ & $\mathrm{M}$ & $\mathrm{M}$ & $\mathrm{M}$ \\
\hline & $\begin{array}{l}\text { IS } \\
\text { RR }\end{array}$ & $I, M$ & $\mathrm{I}, \mathrm{M}$ & $I, M$ & $\mathrm{E}$ & $\mathrm{M}$ & $\mathrm{M}$ \\
\hline Meadow Creek & $\mathrm{PA}$ & - & & & & $I, M$ & M \\
\hline Panther Creek & SP & & $\mathrm{P}$ & $\mathrm{M}$ & M & $\mathrm{M}$ & M \\
\hline Pine Creek & PA & & & & & $I, M$ & M \\
\hline Lemhi River & IF & & & $\mathrm{P}$ & $\mathrm{M}$ & $\mathrm{M}$ & $\mathrm{M}$ \\
\hline Upper Salmon River & IF & & $\mathrm{P}$ & $\mathrm{P}$ & $\mathrm{M}$ & $\mathrm{P}$ & $\mathrm{P}$ \\
\hline & $\mathrm{RR}$ & & $\mathrm{M}$ & $\mathrm{P}$ & M & $\mathrm{P}$ & $\mathrm{P}$ \\
\hline Alturas Lake Creek & IF & & $\mathrm{P}$ & $\mathrm{M}$ & M & $\mathrm{P}$ & $\mathrm{P}$ \\
\hline Pole Creek & $\mathrm{PA}$ & I & $\mathrm{M}$ & $\mathrm{M}$ & M & $\mathrm{E}$ & $\mathrm{E}$ \\
\hline & $\mathrm{RR}$ & & $\mathrm{M}$ & $\mathrm{P}$ & $\mathbf{M}$ & $\mathrm{P}$ & M \\
\hline Valley Creek & $\mathrm{RR}$ & & & $\mathrm{P}$ & M & $\mathrm{M}$ & $\mathrm{M}$ \\
\hline & $\mathrm{PA}$ & & & $\mathrm{P}$ & $\mathrm{M}$ & $\mathrm{M}$ & $I, M$ \\
\hline Bear Valley Creek & SP & & $I, P$ & $\mathrm{I}, \mathrm{P}$ & $I, M$ & M & $\mathrm{M}$ \\
\hline & $\mathrm{RR}$ & & $\mathrm{M}$ & $\mathrm{P}$ & $\mathrm{P}$ & M & $I, M$ \\
\hline Elk Creek & $\mathrm{RR}$ & & $\mathrm{M}$ & $\mathrm{P}$ & $\mathrm{P}$ & M & $I, M$ \\
\hline Marsh Creek & $\mathrm{RR}$ & & M & $\mathrm{P}$ & M & $\mathrm{M}$ & $\mathrm{M}$ \\
\hline Knapp Creek & $\mathrm{PA}$ & & $\mathrm{M}$ & $\mathrm{P}$ & M & $I, M$ & M \\
\hline Camas Creek & $\mathrm{RR}$ & & $\mathrm{M}$ & $\mathrm{M}$ & M & $\mathrm{M}$ & $I, M$ \\
\hline & $\mathrm{BC}$ & & $\mathrm{M}$ & $\mathrm{M}$ & $\mathrm{M}$ & $\mathrm{M}$ & $\mathrm{M}$ \\
\hline $\begin{array}{l}\text { Johnson Creek } \\
\text { South Fork }\end{array}$ & $\mathrm{PA}$ & & $\mathrm{I}, \mathrm{P}$ & $I, E$ & $\mathrm{I}, \mathrm{E}$ & $\mathrm{E}$ & $E$ \\
\hline Tributaries & $\mathrm{PA}$ & & & - & $I, M$ & M & M \\
\hline Boulder Creek & PA & & $\mathrm{P}$ & $I, P$ & $\mathrm{E}$ & M & E \\
\hline Loon Creek & $\mathrm{CO}$ & & & $\mathrm{M}$ & $\mathrm{M}$ & M & \\
\hline Sulphur Creek & $\mathrm{CO}$ & & $\mathrm{M}$ & $\mathrm{M}$ & $\mathrm{P}$ & M & M \\
\hline South Fork Salmon & $\mathrm{co}$ & & $\mathrm{M}$ & $\mathrm{M}$ & M & $\mathrm{M}$ & M \\
\hline
\end{tabular}

$\overline{{ }^{B C}}=$ bank-channel rehabilitation, $\mathrm{CO}=$ control stream, IF = improved flows, IS = instream structure, OC = off-channel developments, $\mathrm{PA}=$ passage, $\mathrm{RR}=$ riparian revegetation, and $\mathrm{SP}=$ sedimentation and pollution control. 


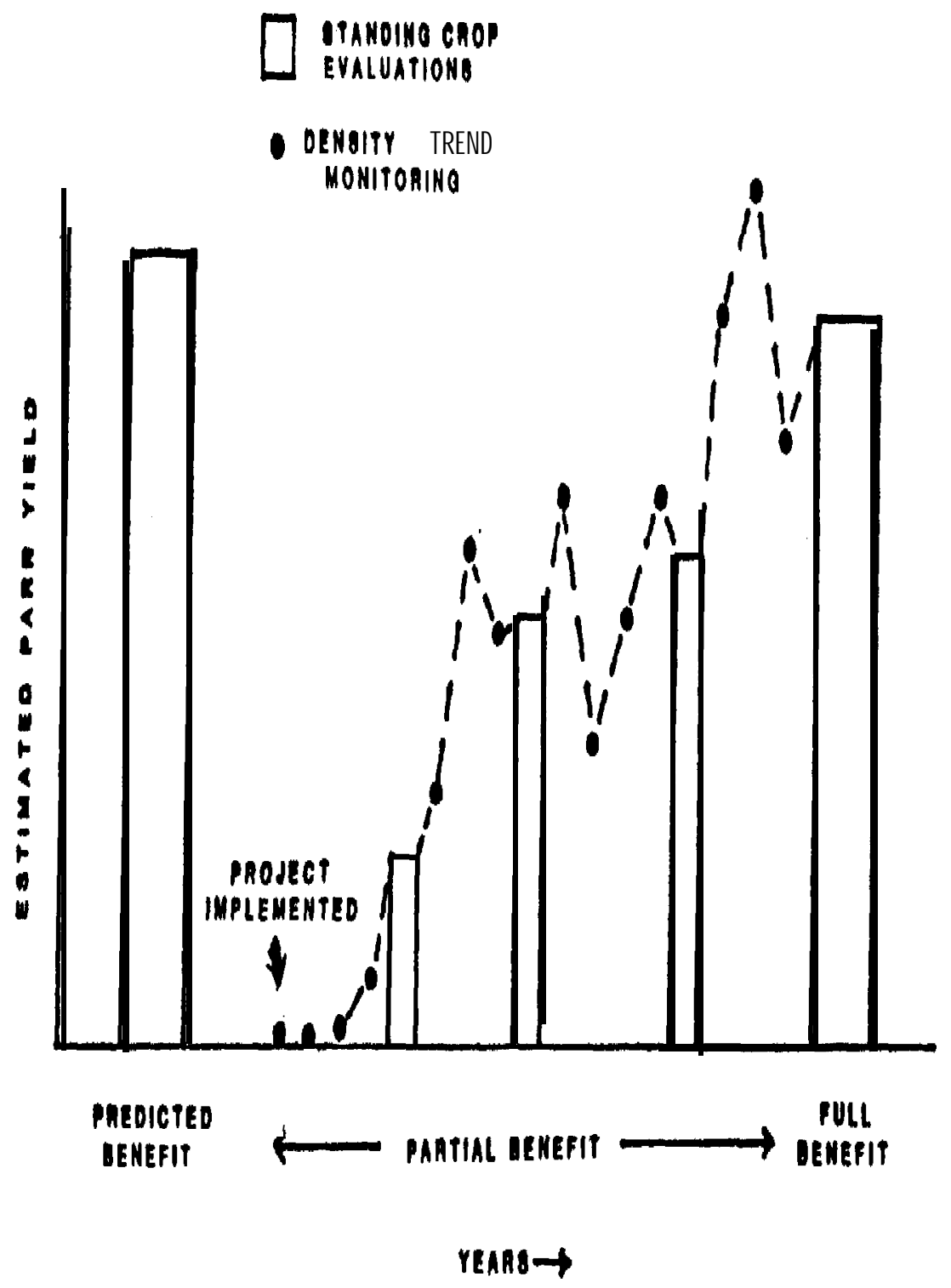

Figure 2. Hypothetical schedule for estimating partial and full benef ts of a project (in terms of parr) from monitoring and evaluation programs. 
densities in all sites need to be sampled within a two-month period from late June to the latter part of August) and because the physical habitat was relatively stable from year to year. The same physical variables were measured in the parallel IDFG-funded monitoring program. BPA and other IDFG monitoring sections are listed in Appendix A-l. IDFG has encouraged other agencies and tribes to incorporate this standardized variable list into their monitoring programs.

Physical habitat variables measured in each section were percent of pool, run, riffle, pocket water, and backwater; percent of substrate surface sand, gravel, rubble, boulder, and bedrock; section length, average width and depth, gradient, and channel type (Rosgen 1985). The techniques used to collect the physical habitat data are described in Petrosky and Holubetz (1988). Physical habitat data collected during 1984-1988 were summarized by channel type. This variable simultaneously categorizes several morphological characteristics, and was used as a primary classification to compare composition of habitat types and substrate within and between streams and to investigate chinook and steelhead rearing potential and population response to sedimentation.

The physical habitat data base will be used in conjunction with data collected by project implementors to develop the mitigation record for BPA habitat projects. Quantity and quality of habitat added and improved will be estimated. Actual and potential production of steelhead and chinook parr attributable to each project will be estimated using relationships developed from this data base.

The substrate variable, percent sand, was analyzed relative to its effects on parr densities. Parr densities for chinook in $\mathrm{C}$ channels and steelhead in B channels were examined relative to percent sand for all monitoring sections. In addition, the effects of substrate sand on parr densities in the Middle Fork of the Salmon River drainage were also analyzed separately. All major Middle Fork Salmon River tributaries have wild spring chinook populations. Most of the tributaries are in pristine watersheds, while others have been entered for mining and grazing. Thus the Middle Fork Salmon River is an excellent drainage to evaluate the effects of land use on sedimentation and chinook salmon populations.

\section{Parr Density Monitoring}

In 1984-1988, the BPA general monitoring and intensive studies established a total of 166 monitoring sections to index the annual abundance of steelhead and chinook parr in BPA habitat project streams. Steelhead parr are defined here as ages-1+ and -2+, with respective lengths of 3" to 5.9" and 6" to 8.9". The steelhead length-at-age intervals are similar to those defined metrically by Thurow (1987). Chinook parr are age-0+, with lengths less than 4". These data, and data from the parallel IDFG-funded monitoring program, were used to index trends in annual abundance, estimate rearing potential in different habitats, and develop relationships between adult escapements and juvenile fish densities. Mitigation benefits are being determined in part from density trends and habitatfish relationships developed from this data base. 
Most anadromous fish production streams in Idaho are clear and have low conductivity. In these streams, snorkeling counts by trained observers are preferred over estimates obtained from electrofishing. Comparisons of snorkel counts and electrofishing estimates in typical Idaho anadromous streams (Petrosky and Holubetz 1987) demonstrated that direct observation is an excellent method of censusing salmon and steelhead parr populations. Hankin and Reeves (1988) presented similar evidence for western Oregon streams. In larger streams, electrofishing surveys are neither practical nor reliable for juvenile fish. We obtained density estimates by snorkeling in all sections, except those in the highly conductive and slightly turbid Lemhi River, which we electrofished. Census methods and fish population field forms were presented in Petrosky and Holubetz (1986).

We snorkeled the monitoring sections with a team of divers working upstream. Crew size ranged from one for small streams to five or more for larger streams. Additional sections in large main stem rivers (Appendix A-2) were snorkeled by IDFG's fisheries management personnel. Corridors, rather than entire widths, of these main stem sections were sampled by floating from the upper to the lower end of the section. Relative parr density was based on surface area of the corridor visible to the observer. Data from these samples were analyzed and reported separately from the general monitoring sections.

The combined programs monitored sections in 100 streams, representing a variety of stocks, production types, and habitats. Parr densities were compared among all major anadromous fish drainages in Idaho during 1985-1988. We summarized steelhead and chinook parr densities by year, production type (wild or natural), and channel type. We analyzed A-run and B-run steelhead separately because of large differences in Columbia River harvest rates and escapements between the two runs.

We also estimated parr density as a percent of carrying capacity (PCC) using standardized smolt capacity ratings developed for Subbasin Planning by the Northwest Power Planning Council (NWPPC 1986). The parr density data base was merged with the NWPPC's species presence/absence data base using the common variable, EPA reach number. The NWPPC file rates each EPA reach as being poor, fair, good, or excellent habitat for rearing chinook and steelhead smolts. We converted the NWPPC smolt ratings to parr capacities to estimate PCC. Petrosky and Holubetz (1988) defined parr carrying capacity in excellent habitat as $108 / 100 \mathrm{~m}^{2}$ for chinook and $20 / 100 \mathrm{~m}^{2}$ for steelhead. The NWPPC smolt capacity rating from excellent habitat for chinook and steelhead are 90 and IO smolts/100 $\mathrm{m}^{2}$. Chinook parr carrying capacity for poor, fair, and good habitat were determined proportionally from NWPPC smolt ratings as 12,44 , and $77 / 100 \mathrm{~m}^{2}$. Steelhead parr carrying capacity was similarly estimated as 6 , IO and $14 / 100 \mathrm{~m}^{2}$, respectively. Excellent habitat for chinook would be undisturbed C channel streams, and good habitat would be in similar quality B channels. For steelhead, excellent habitat would be in undisturbed B channels, and good habitat would be in undisturbed C channels. C channels in some spring fed streams could also be classified as excellent steelhead rearing habitat. Degraded streams received ratings of fair and poor for both species depending'on the degree of disturbance and channel type.'. 


\section{Anadromous Fish Introductions}

The 1984-1988 chinook and steelhead releases into BPA project and monitoring streams are summarized in Appendices A-3 and A-4, respectively. Chinook fry were stocked by this project in 1988 to establish populations above barrierremoval projects and to evaluate chinook rearing potential in different habitats in Johnson Creek and in upper Lochsa River tributaries.

\section{Steelhead Rearing Potential}

Inferences into steelhead rearing potential in different habitats were drawn from annual monitoring of parr densities during the five years of this project. We averaged observed densities for sections with greater than $75 \%$ of the rated carrying capacity and compared these averages to the current carrying capacity ratings for poor, fair, good, and excellent habitat. The comparison demonstrated whether or not the ratings were similar to observed densities which may approach carrying capacity. This data subset was used since wild and natural steelhead escapements are generally depressed in Idaho. As an example of present depressed conditions, wild adult steelhead past Rapid River Hatchery weir in 1983-1986 averaged only 39\% of the 1968-1972 escapements (Petrosky and Holubetz 1988).

\section{Chinook Rearinq Potential}

Inferences into chinook rearing potential were drawn from annual monitoring of parr densities and from fry outplants designed to test carrying capacity in different habitats.

A subset of observed densities for sections with greater than $75 \%$ of the rated carrying capacity from 1984-1988 was created and compared to parr carrying capacity ratings. We consider most of the sections in this subset underseeded and believe the average of these observed densities represent conservative estimates of rearing potential.

Chinook fry stocking in 1988 was designed to establish populations and to estimate rearing potential in portions of Johnson Creek and upper Lochsa River tributaries: Crooked Fork, Hopeful, White Sand, and Big Flat Creeks. Johnson Creek and its tributaries, Rock and Sand Creeks, were stocked on May 9 by helicopter with a total of 195,400 McCall summer chinook fry (average 439/pound). Four sites in the upper Lochsa River were stocked by helicopter on May 10 and 11, 1988, with 283,300 Rapid River spring chinook fry (average 367/pound).

The four stocking sites in the upper Lochsa River tributaries represented a range of stream size, gradient, and channel type in nondegraded habitat (Figure 3). Number of fry stocked at each site was based on its stream width. 


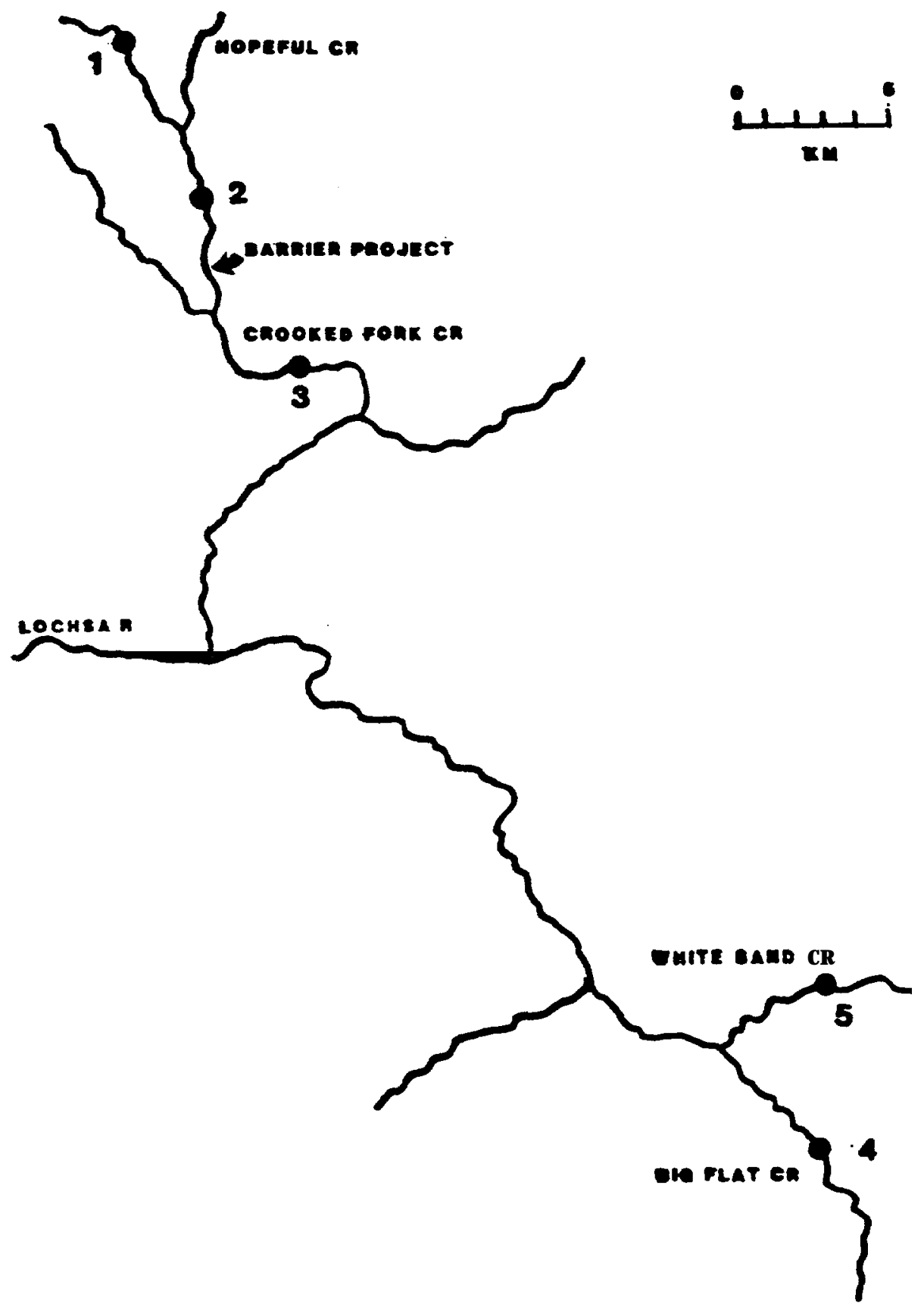

Figure 3. Chinook fry stocking sites, upper Lochsa River tributaries, 1987. 
A site estimated to be $20 \mathrm{~m}$ wide would receive four times the number of fry stocked in a $5 \mathrm{~m}$ wide site (Table 3). Based on an initial expectation of 15\% fry-to-parr survival (Petrosky and Holubetz 1988), the stocking rate in the upper Lochsa River tributaries would seed $1.16 \mathrm{~km}$ of stream at an average density of 100 parr $/ 100 \mathrm{~m}^{2}$.

To estimate survival of these fry to the parr stage, we systematically established snorkel sections at $0.5 \mathrm{~km}$ intervals beginning at each stocking site and extending $1.0 \mathrm{~km}$ upstream and $3.0 \mathrm{~km}$ downstream. We measured habitat variables and estimated fish densities during August 9-15, 1988. Petrosky and Holubetz (1988) described the procedures used to estimate total abundance and fry-to-parr survival based on systematic stratified sampling of parr densities in the established sections.

Parr migrated out of upper Johnson Creek prior to sampling in 1988. Thus, it was not possible to estimate fry-to-parr survival and chinook parr carrying capacity in Johnson Creek in 1988.

\section{Chinook Reproduction Curves}

Columbia River Basin system planning documents (NWPPC 1986) assume smolt carrying capacity of rearing habitat to be a density-dependent relationship in the form of a Beverton-Holt function (Ricker 1975). As redd densities increase, smolt (or parr) densities increase to an asymptote (carrying capacity).

Densities of age-O+ chinook from Salmon River streams in 1984-1988 were compared to densities of redds in IDFG spawning ground survey reaches of the same streams. The comparison was limited to low gradient ( $C$ channel) reaches that have a predominance of age-5 ${ }_{2}$ (age-5, two years in freshwater, three years in saltwater) spawners (Table 4). We classified the stream reaches by average percent substrate surface sand measured in the monitoring sections $(<30 \%, 30-$ $40 \%$, and $>40 \%$ ). Linear and Beverton-Holt regressions were fitted to the data.

\section{Chinook Eqq-to-Parr Survival}

A comparison was made between efficiencies of supplementation methods by stocking a known number of eyed eggs and fry in different streams. Abundance of the resulting parr were estimated the following summer. Estimated survival in hatcheries from green egg to eyed egg was assumed to be $85 \%$, and from green egg to fry 75\% (S. Huffaker, IDFG, personal communication).

\section{Partial Project Benefits}

Partial project benefits were estimated from 1985 through 1988 according to the project-specific approaches in Petrosky and Holubetz (1986) and 
Table 2. Number of sections where steelhead and chinook parr were monitored by BPA project 83-7 and the IDFG management and research programs from 1984 through 1988 .

\begin{tabular}{lcc}
\hline Year & $\begin{array}{c}\text { Number of } \\
\text { steelhead }\end{array}$ sections & $\begin{array}{c}\text { Number of } \\
\text { chinook sections }\end{array}$ \\
& & 37 \\
1985 & 189 & 139 \\
1986 & 190 & 156 \\
1987 & 225 & 178 \\
1988 & 225 & 175 \\
\hline
\end{tabular}

${ }^{a}$ Chinook sections are a subset of the steelhead sections.

Table 3. Chinook fry stocking summary for rearing-potential investigations, upper Lochsa River tributaries, 1988.

\begin{tabular}{|c|c|c|c|c|c|}
\hline \multirow{2}{*}{$\begin{array}{c}\text { Stream, } \\
\text { stocking site }\end{array}$} & \multirow{2}{*}{$\begin{array}{c}\text { Estimated } \\
\text { width }^{\mathrm{a}}\end{array}$} & \multicolumn{4}{|c|}{ Chinook frv } \\
\hline & & Number & Number/lb. & Date & Method \\
\hline $\begin{array}{c}\text { Crooked Fork Creek } \\
1 .\end{array}$ & 5.4 & 40,600 & 379 & $5 / 10 / 88$ & helicopter \\
\hline $\begin{array}{c}\text { Hopeful Creek } \\
2 .\end{array}$ & 5.9 & 62,200 & 379 & $5 / 10 / 88$ & helicopter \\
\hline Big Flat Creek & 9.0 & 72,200 & 361 & $5 / 11 / 88$ & helicopter \\
\hline Sand 4 & 14.0 & 108,300 & 361 & $5 / 11 / 88$ & helicopter \\
\hline
\end{tabular}

"Estimated from past data and aerial inspection (4/27/87).

$\mathrm{b}_{\mathrm{An}}$ additional 19,500 fry were stocked near the mouth of White Sand Creek. 
Table 4. Spawning ground survey reaches and parr monitoring sections of the Sal mon River and trlbutaries used to develop chinook reproduction curves, brood years, 1983.1987.

\begin{tabular}{|c|c|c|c|c|c|}
\hline $\begin{array}{l}\text { Sand } \\
\text { class }\end{array}$ & Stream & $\begin{array}{l}\text { Spawning Ground } \\
\text { survey reach } \\
\text { upstream/downstream }\end{array}$ & Hectares & $\begin{array}{l}\text { Mean } \\
\text { percent } \\
\text { sand } \\
\end{array}$ & $\begin{array}{l}\text { Density } \\
\text { Monitoring } \\
\text { Sections }\end{array}$ \\
\hline \multirow[t]{11}{*}{$<30 \%$} & Sal mon River & $\begin{array}{l}\text { headwaters/diversion } \\
\text { diversion/R. S. bridge } \\
\text { R. S. br. /Sawtooth weir }\end{array}$ & $\begin{array}{r}3.5 \\
19.2 \\
33.6\end{array}$ & $\begin{array}{l}19.7 \\
17.2 \\
17.2\end{array}$ & $\begin{array}{l}8 A, 8 B, 9 A, 9 B, 10 A, 10 B \\
5 B, 6 A, 6 B, 7 A, 7 B \\
3 A, 3 B, 4 A, 4 B, 5 A\end{array}$ \\
\hline & Alturas Lake $\mathrm{Cr}$. & $\begin{array}{l}\text { Al pine Cr./Alturas Lake } \\
\text { Cabin Cr. Bridge/mouth }\end{array}$ & $\begin{array}{l}2.6 \\
4.1\end{array}$ & $\begin{array}{l}29.0 \\
10.0\end{array}$ & $3^{1 A, 2 A}$ \\
\hline & Pole Creek & $\begin{array}{l}\text { headwaters/diversion } \\
\text { di version/mouth }\end{array}$ & $\begin{array}{l}3.3 \\
2.8\end{array}$ & $\begin{array}{l}16.0 \\
20.5\end{array}$ & $\begin{array}{l}1 A, 1 B, 2 A, 2 B \\
3 A, 3 B\end{array}$ \\
\hline & Valley Creek & Trap Cr./Stanley Lk. $\mathrm{Cr}$. & 8.4 & 26.0 & $3 A, 3 B$ \\
\hline & E. Fk, Salmon R. & wei $r /$ Herd Creek & 15.2 & 15.0 & 5 \\
\hline & Marsh Creek & airstrip/Cape Horn $\mathrm{Cr}$. & 8.6 & 23.7 & $4 \mathrm{~B}, 5 \mathrm{~A}, 6 \mathrm{~A}$ \\
\hline & Knapp Creek & beaver ponds / mouth & 2.1 & 27.0 & $1 \mathrm{~A}$ \\
\hline & Cape Horn Creek & Banner $\mathrm{Cr}$. / mouth & 5.1 & 13.5 & $1 A, 2 B$ \\
\hline & Beaver Creek & Bear Cr./bridge & 8.0 & 8.0 & $1 A, 3 B$ \\
\hline & Loon Creek & Cabin $\mathrm{Cr}$. / steep canyon & 4,5 & 23.5 & 1,2 \\
\hline & Camas Creek & Castle $\mathrm{Cr}$./Hammer $\mathrm{Cr}$. & 15.6 & 9.0 & 1.2 \\
\hline \multirow[t]{2}{*}{$30-40 \%$} & Bear Valley Crk. & mine/ETkCreek & 23.8 & 35.7 & $3 A, 5 A, B i g \cdot m d w$ \\
\hline & Sulphur Creek & Ranch/ I ower & 5.2 & 33.0 & $4 A, 4 B$ \\
\hline \multirow[t]{3}{*}{$\geq 40 \%$} & Valley Creek & Stanley Lk, Cr/mouth & 19.3 & 46.0 & 18 \\
\hline & Bear Valley Crk. & Elk $\mathrm{Cr}, / \mathrm{Fir} \mathrm{Cr}$. & 26.1 & 57.0 & $2 A, 2 B$ \\
\hline & Elk Creek & $\begin{array}{l}\text { W. F, El k } \mathrm{Cr}, / \text { Bearskin } \\
\text { Bearskin } \mathrm{Cr}, \text { / } \\
\text { Bear Vall ey }\end{array}$ & $\begin{array}{l}11.3 \\
14.6\end{array}$ & $\begin{array}{l}45.0 \\
46.0\end{array}$ & $\begin{array}{l}2 A, 2 B \\
1 A, 1 B\end{array}$ \\
\hline
\end{tabular}


Appendix B. The interim benefits are expressed in terms of parr production until reliable estimates of parr-to-smolt survival rates become available, beginning in 1989 .

Four general types of habitat improvement projects were evaluated: barrier removals, off-channel developments, instream structures, and sediment reduction. Barrier removals and off-channel developments were evaluated by estimating the population of affected anadromous salmonids which were rearing above the barrier removal site or within the off-channel developments. These analyses were done with stratified systematic sampling (Cochran 1963). In years when populations were not estimated, densities in the affected areas were monitored at one or more snorkeling sections.

The Clearwater and Nez Perce National Forests placed structures in Crooked River, Red River, and Lolo Creek as mitigation for habitat degradation resulting from mining, grazing, and logging activities. During the four years following these structure placements, the IDFG monitored control and treated stream sections to evaluate project benefits in terms of increased parr densities.

In some years and streams, a larger number of replicate sections were sampled to analyze responses of parr densities within a given year (Petrosky and Holubetz 1985, 1986, 1987). For this report, we analyzed monitoring data replicated annually from 1985 through 1988, from control and treatment sections in two strata (stream reaches) each of Crooked River, Lolo Creek, and Red River. We analyzed instream structures separately for each of the three streams, then grouped the streams in a second analysis. The response variables were densities of age-1+ and $\mathbf{- 2 +}$ steelhead and age-0+ chinook.

For each stream, a two-factor analysis of variance with factors of treatment and stream stratum was used to test for density differences between treated and control sections. Data were then combined from the three streams and tested with a randomized block analysis of variance with repeated measures on years. The latter analysis increased degrees of freedom, sample size, and thus the power to detect differences. Treatments evaluated consisted of boulder clusters and log weirs (sill logs) on Crooked River; boulder clusters and deflector logs on Red River; and boulder clusters, log weirs, and deflector logs on Lolo Creek.

\section{Data Base Manaqement and Statistical Analyses}

All biological and physical data from 1984 through 1988 were entered into dBase IIIt files for easy access and arrangement for various analyses. These files are now available for use by project implementors, Tribes, and natural resource agencies upon request.

Summary statistics, analysis of variance, post-hoc comparisons, and regressions were done with the statistical software SYSTAT (SYSTAT 1988). Tests of significance were all at the 95\% level. 


\section{RESULTS}

\section{Physical Habitat}

We classified the monitoring sections according to two major channel types (Rosgen 1985) and compared parr density trends within channel types. Petrosky and Holubetz (1988) demonstrated the effect of channel type on both steelhead and chinook parr densities. A comparison of parr densities in Rosgen's $\mathrm{C}$ and B channels showed that chinook densities were higher in C channels, while steelhead densities were higher in B channels. B channels are confined in steepsided valleys or canyons and have high enough gradient that most fine materials are flushed out. A significant part of the substrate composition may be comprised of boulders larger than $30 \mathrm{~cm}$ diameter. C channel streams, in contrast, meander through flat, alluvial valleys and are characterized by lower velocities and deposition of fine materials. Substrate composition in channels has a high percentage of small materials, sand, and gravel. In unstable watersheds, sand may be the predominant substrate type.

The $\mathrm{B}$ and $\mathrm{C}$ channel classifications were qualitative and allowed an observer to look at a stream and determine if it had a B or C channel without measuring sinuosity, width-depth ratio, and other variables described by Rosgen. According to Rosgen's classification, B and C channel types separate at a gradient of 1.5\%. Our channel type classification deviated slightly from Rosgen's in this respect. Of 99 monitoring sites (with measured gradients) that we classified as B channel, 64 had a gradient estimate of less than 1.5\%, whereas only 5 of 78 measured $C$ channel sections had gradients in excess of $1.5 \%$. Gradients measured for the monitoring sections may have differed slightly from the average gradient over a longer stream reach. Overall, however, the mean gradient for $B$ channels $(2.4 \%)$ was 3.4 times greater than for C channels $(0.7 \%)$, similar to Rosgen's values (Figure 4).

Mean width and depth of both channel types were similar (Figure 4), with both having a width-to-depth ratio of approximately 37 . On average, sections classified as B channels had less pool and run habitat than C channels (55\% versus 74\%, respectively) and much more pocket water $(26 \%$ versus $2 \%$, respectively) (Figure 5). Pocket water is generally formed by boulders; a substrate type not commonly exposed in low gradient, depositional C channels.

The relative importance of boulders in $\mathrm{B}$ and $\mathrm{C}$ channels is further illustrated in the summaries of substrate. B channel substrate averaged 28\% boulder, compared to $4 \%$ in C channels. Conversely, sand and gravel, materials most easily moved by stream flow, covered 71\% of $\mathrm{C}$ channel bottoms, compared to only 38\% in B channels (Figure 6). 


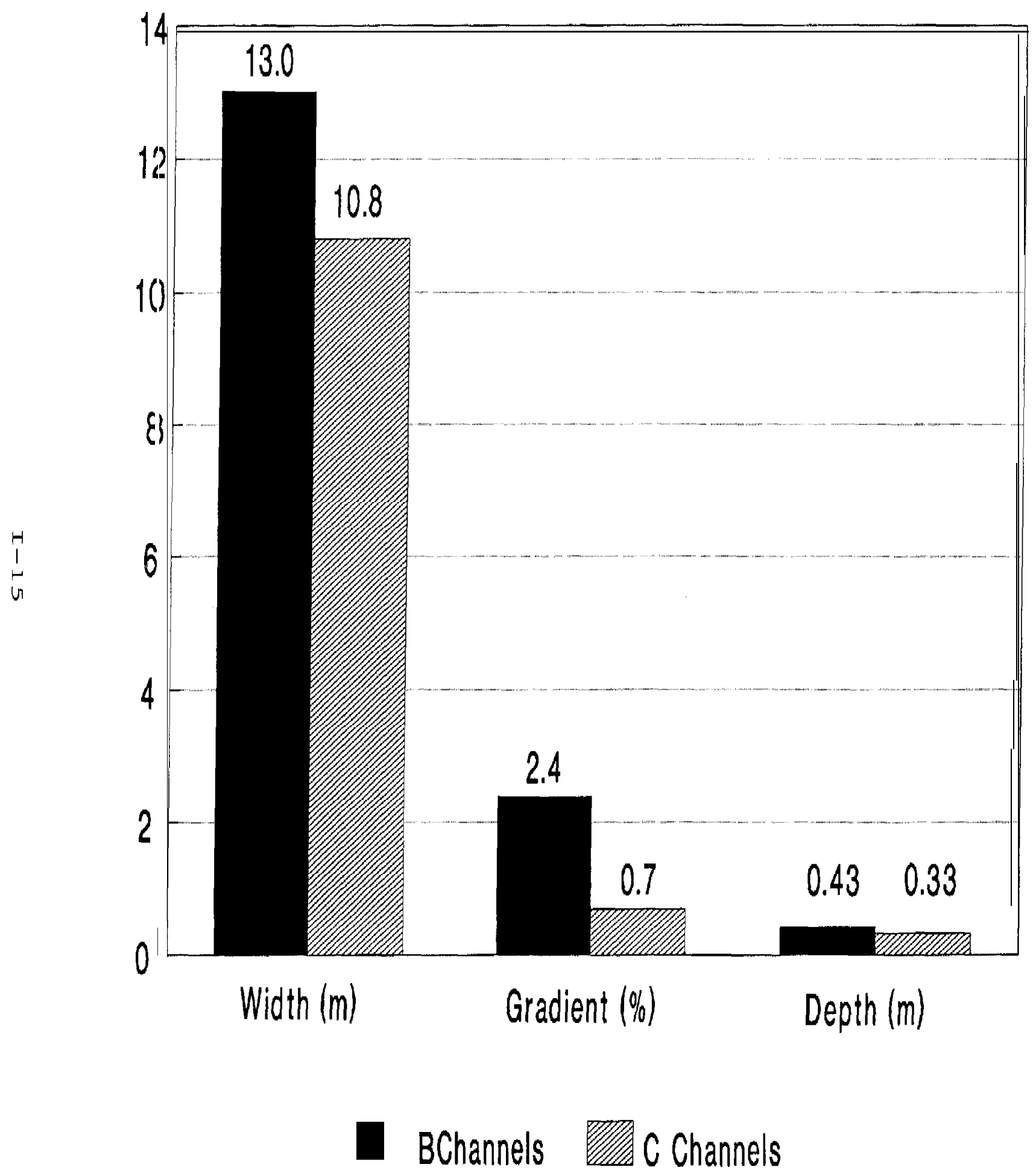

Figure 4, Mean width, depth, and gradient for B and C channels in monitoring sections, 


\section{Type B Channels}

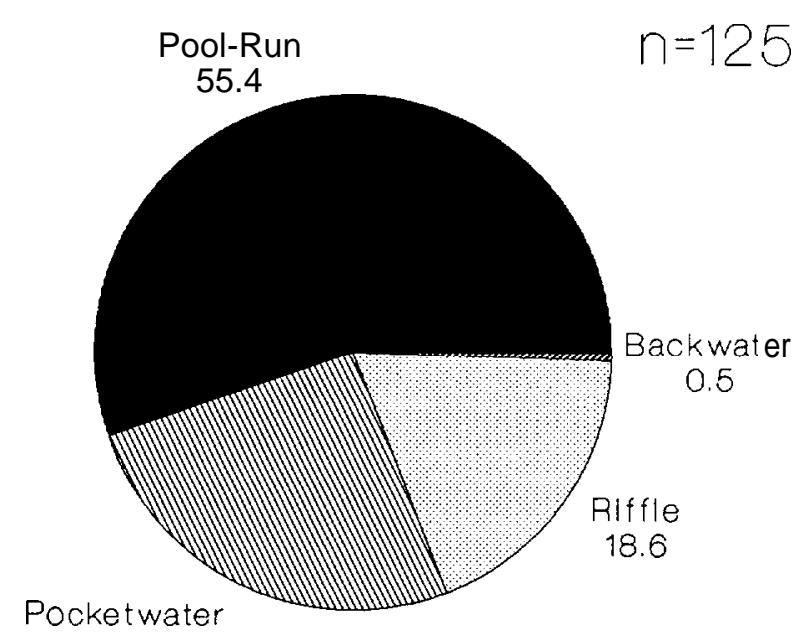

25.6

Type C Channels

$n=96$

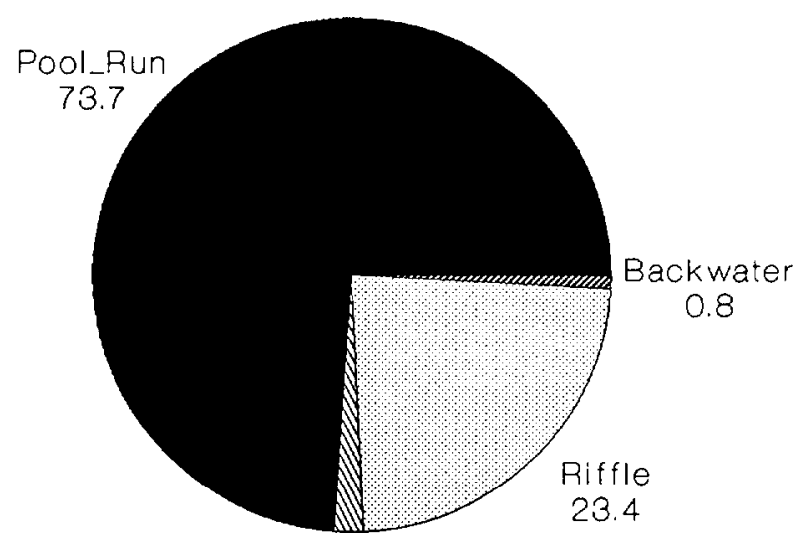

Pocketwater

1.8

Figure 5. Percentages of the different habitat types in B and C channel monitoring sections. 


\section{Type B channels}

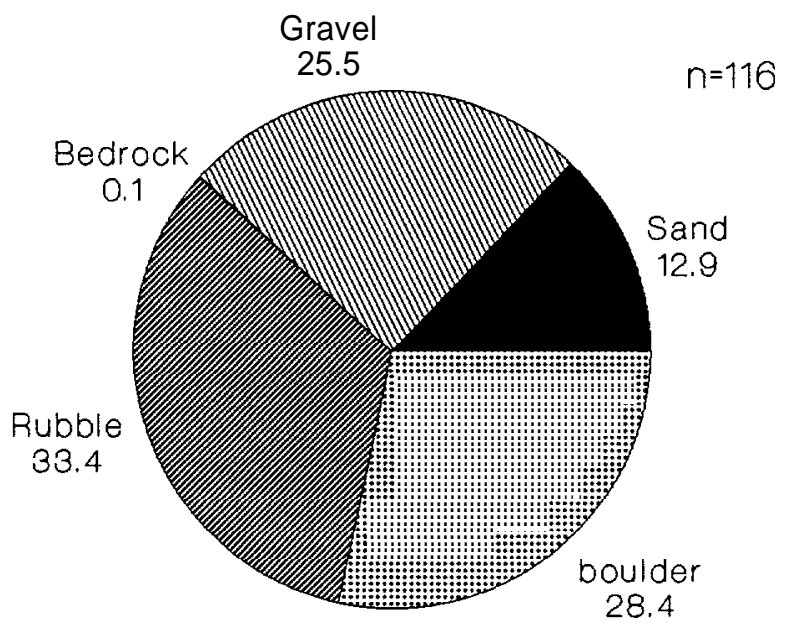

Type C channels

$n=106$

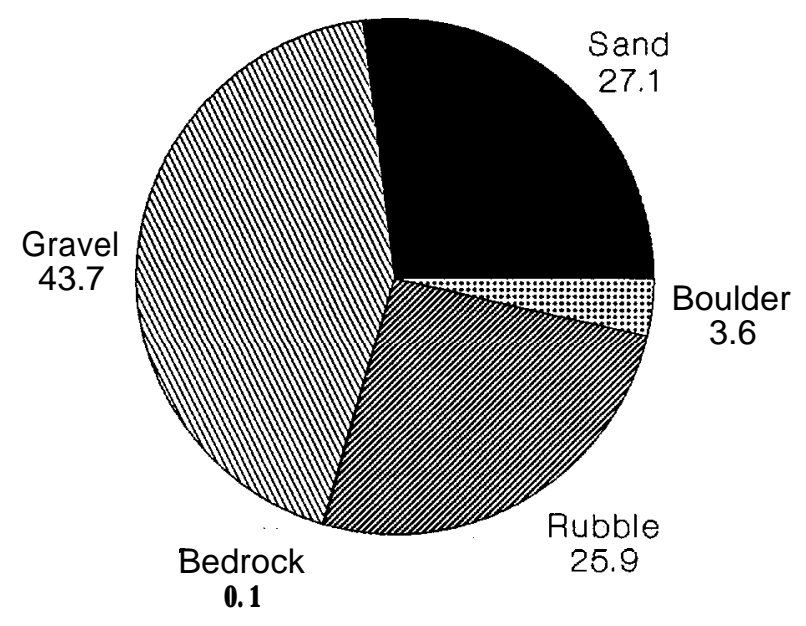

Figure 6. Percentages of the different substrate categories in $B$ and $C$ channel monitoring sections. 


\section{Substrate Sand and Parr Densities}

\section{Chinook Parr}

This project has recorded percent sand at all parr monitoring sites using the IDFG ocular method (Torquemada and Platts 1988). C channel streams, because of their low gradient, generally contain sand. However, if the amount of sand becomes excessive, chinook egg survival and percent emergence decline (Chapman 1988).

OEA $(1987 a, b)$ demonstrated in the upper Salmon River and Middle Fork Salmon River drainages direct relationships between the amount of grazing that occurred upstream from a sampling site and the percent surface sand (particles $<6.4 \mathrm{~mm}$ in diameter). Additionally, the OEA studies and Petrosky and Holubetz (1987) demonstrated inverse relationships between percent sand, percent gradient, and the density of chinook parr rearing in that stream section.

We ran one-way analysis of variance (AOV) comparisons of the effect of sand on chinook parr density. The AOV probably underestimated sediment effects however, because the tests did not account for the interactive effect of gradient on deposition of sand. Even though $\mathrm{C}$ channel sections are generally depositional areas, sections with the highest gradients (within the C channel classification) would have a positive effect on chinook density due to reduced sand, but a negative effect due to higher water velocity.

For all monitoring sections combined, the mean chinook parr density was lowest $\left(14.1 / 100 \mathrm{~m}^{2}\right.$ ) in C channel streams where percent sand was < 10\% (Table 5). This percent sand interval also had the highest average gradient $(1.0 \%)$, much higher than in the other percent sand classes (0.5-0.6\%). These higher $\mathrm{C}$ channel gradients appear to represent a transition between $B$ and $C$ channels. Mean chinook density for all $\mathrm{B}$ channels was only $5.5 / 100 \mathrm{~m}^{2}$.

Highest mean density of chinook parr for all monitoring sections combined was in the 10-20\% sand interval, with density declining at a modest rate for each $10 \%$ increase in percent sand above $20 \%$. Sections exceeding $40 \%$ sand averaged 15.9 chinook parr $/ 100 \mathrm{~m}^{2}, 67 \%$ of the highest density interval. Gradient was lowest for this interval, which without sediment effects should have been desirable for chinook parr. AOV indicated that none of the mean values were significantly different.

We also summarized sediment data by the three intervals used by OEA $(1987 a, b): 0-30 \%, 30-40 \%$ and $>40 \%$. AOV indicated no significant difference in chinook parr densities for all C channel monitoring sections among the three classes.

Maximum chinook parr densities for all C channel sections showed no significant differences between any sediment classes (Table 5). 
Unlike the data set for all C channel sections, the MFSR chinook parr densities differed significantly between sediment classes (Table 5). As sediment increased, mean and maximum MFSR densities decreased. The decline appeared to begin at sediment levels greater than 20\% surface sand. Sample variance was relatively high, so that many apparent class differences did not differ significantly.

The MFSR data subset probably best represents sediment effects on chinook parr density because more of the extrinsic variation was controlled. The statewide data included areas that were supplemented and unsupplemented, as well as within basalt and batholith (granitic) watersheds, where different physical and biological responses might be expected. The MFSR data subset was entirely from batholith streams and these wild spring chinook stocks were subjected to similar smolt passage conditions and adult harvest rates.

\section{Steelhead Parr}

We compared steelhead parr (age-1+ and $\mathbf{- 2 +}$ ) densities in different sediment classes of B channels (Table 6), similar to above comparisons for chinook parr in $\mathrm{C}$ channels. The only significant decreases in steelhead parr density occurred between the 0-10\% and the 10-20\% intervals for the statewide means. Neither mean nor maximum densities of steelhead parr in B channel monitoring sites demonstrated a relationship with changes in percent sand where percent sand exceeded $10 \%$.

No significant differences between sediment classes occurred in AOV tests for MFSR steelhead parr densities (Table 6), possibly due to small sample size for several classes. The steelhead parr data from the MFSR drainage had few samples in the sections with greatest amounts of sand. To test the hypothesis that percent sand (from $\mathbf{0 - 4 0 \%}$ ) has no effect on steelhead parr density, more samples would be needed from all areas with more than $10 \%$ sand.

\section{Bear Valley/Elk Creek verses Control Streams}

In the MFSR drainage we compared wild chinook and steelhead parr densities in monitoring sections of the heavily sedimented Bear Valley/Elk Creek drainage with sections in cleaner (control) batholith streams. Percentage of the substrate surface which was sand averaged 46\% in Bear Valley/Elk Creek and 20\% in control stream sections (Appendix C). Parr densities from these streams were analyzed by one-way analyses of variance with repeated measures on years. The SYSTAT model required that five sections which had one or more missing samples during 1985-88 be discarded from the data set since each measure must be repeated for each year. All 1984 data were removed since few sections were sampled that year. Appendix C reports only the stream sections used in the AOV. Chinook and steelhead parr densities in the control streams were significantly higher $(p<0.00)$ than for the sedimented Bear Valley/Elk Creek drainage, averaging 13.5 and 9.3 times higher, respectively (Figure 7). 
Table 5. Mean and maximum chinook density by sediment class for C channel monitoring sections statewide and in the Middle Fork Salmon River (MFSR) drainage, 1984-88.

\begin{tabular}{|c|c|c|c|c|c|c|c|c|}
\hline \multirow[b]{2}{*}{$\begin{array}{l}\frac{0}{6} \\
\text { sand }\end{array}$} & \multicolumn{4}{|c|}{ Statewide } & \multicolumn{4}{|c|}{ MF SR } \\
\hline & $\begin{array}{l}\text { Mean } \\
\text { dens }\end{array}$ & $(n)$ & $\begin{array}{l}\text { Max. } \\
\text { dens }\end{array}$ & $(n)$ & $\begin{array}{l}\text { Mean } \\
\text { dens }\end{array}$ & $(n)$ & $\begin{array}{l}\text { Max. } \\
\text { dens }\end{array}$ & (n) \\
\hline $\begin{array}{r}0-10 \\
10-20 \\
20-30 \\
30-40 \\
>40\end{array}$ & $\begin{array}{l}14.1 \\
23.6 \\
20.6 \\
18.9 \\
15.9\end{array}$ & $\begin{array}{l}(56) \\
(81) \\
(68) \\
(39) \\
(56)\end{array}$ & $\begin{array}{l}31.2 \\
33.8 \\
31.2 \\
27.4\end{array}$ & $\begin{array}{l}(14) \\
(20) \\
(11)\end{array}$ & $\begin{array}{r}26.9 \\
30.2 \\
14.9 \\
16.0 \\
1.5\end{array}$ & $\begin{array}{c}(16) \\
(19) \\
(27) \\
(12) \\
(32)\end{array}$ & $\begin{array}{r}53.0 \\
53.9 \\
22.5 \\
29.8 \\
3.6\end{array}$ & 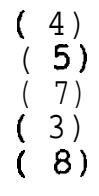 \\
\hline P & 0.16 & & 0.62 & & $0.01^{\mathrm{a}}$ & & $0.02^{b}$ & \\
\hline $\begin{array}{r}0-30 \\
30-40 \\
>40\end{array}$ & $\begin{array}{l}19.9 \\
18.9 \\
15.9\end{array}$ & $\begin{array}{r}(205) \\
(39) \\
(56)\end{array}$ & $\begin{array}{l}36.8 \\
31.2 \\
27.4\end{array}$ & $\begin{array}{l}(56) \\
(11) \\
(15)\end{array}$ & $\begin{array}{r}22.7 \\
16.0 \\
1.5\end{array}$ & $\begin{array}{c}(62) \\
(12) \\
(32)\end{array}$ & $\begin{array}{r}39.9 \\
29.8 \\
3.6\end{array}$ & $\begin{array}{l}(16) \\
(3) \\
\left(\begin{array}{c}3 \\
8\end{array}\right)\end{array}$ \\
\hline $\mathrm{P}$ & 0.54 & & 0.64 & & $0.00^{\circ}$ & & $0.04^{d}$ & \\
\hline
\end{tabular}

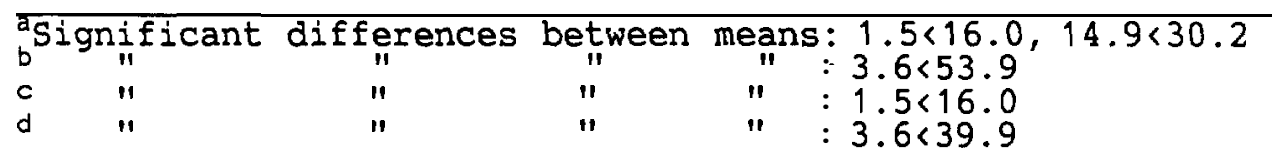

Table 6. Mean and maximum ages-1+ and $\mathbf{- 2 +}$ steelhead parr density by sediment class for $B$ channel monitoring sections statewide and in the Middle Fork Salmon River (MFSR) drainage, 1984-88.

\begin{tabular}{|c|c|c|c|c|c|c|}
\hline & \multicolumn{4}{|c|}{ Statewide } & \multicolumn{2}{|c|}{ MF SR } \\
\hline $\begin{array}{l}\frac{0}{0} \\
\text { sand }\end{array}$ & $\begin{array}{l}\text { Mean } \\
\text { dens }\end{array}$ & $(n)$ & $\begin{array}{l}\text { Max. } \\
\text { dens }\end{array}$ & (n) & $\begin{array}{l}\text { Mean } \\
\text { dens. (n) }\end{array}$ & $\begin{array}{l}\text { Max. } \\
\text { dens. }\end{array}$ \\
\hline $\begin{array}{r}0-10 \\
10-20\end{array}$ & $\begin{array}{l}7.6 \\
3.6\end{array}$ & $\begin{array}{r}(257) \\
(81)\end{array}$ & $\begin{array}{r}11.4 \\
6.5\end{array}$ & $\begin{array}{l}(74) \\
(25)\end{array}$ & $3.8 \quad(50)$ & $\begin{array}{ll}6.7 & (13) \\
9.4 & (12)\end{array}$ \\
\hline $\begin{aligned} 80 & -30 \\
& >40\end{aligned}$ & $\begin{array}{l}2.3 \\
5.1 \\
2.4\end{array}$ & $\begin{array}{l}(56) \\
(22) \\
(11)\end{array}$ & $\begin{array}{l}39.9 \\
2.9\end{array}$ & $\left(\begin{array}{r}(18) \\
3)\end{array}\right.$ & 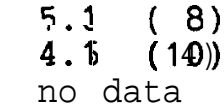 & $\begin{array}{l}2.3 \quad(3) \\
11.7 \quad(1) \\
\text { no data }\end{array}$ \\
\hline $\mathrm{P}$ & $0.00^{\mathrm{a}}$ & & $0.00^{b}$ & & 0.33 & 0.38 \\
\hline
\end{tabular}

asignificant differences between means: $3.6<7.6$ 

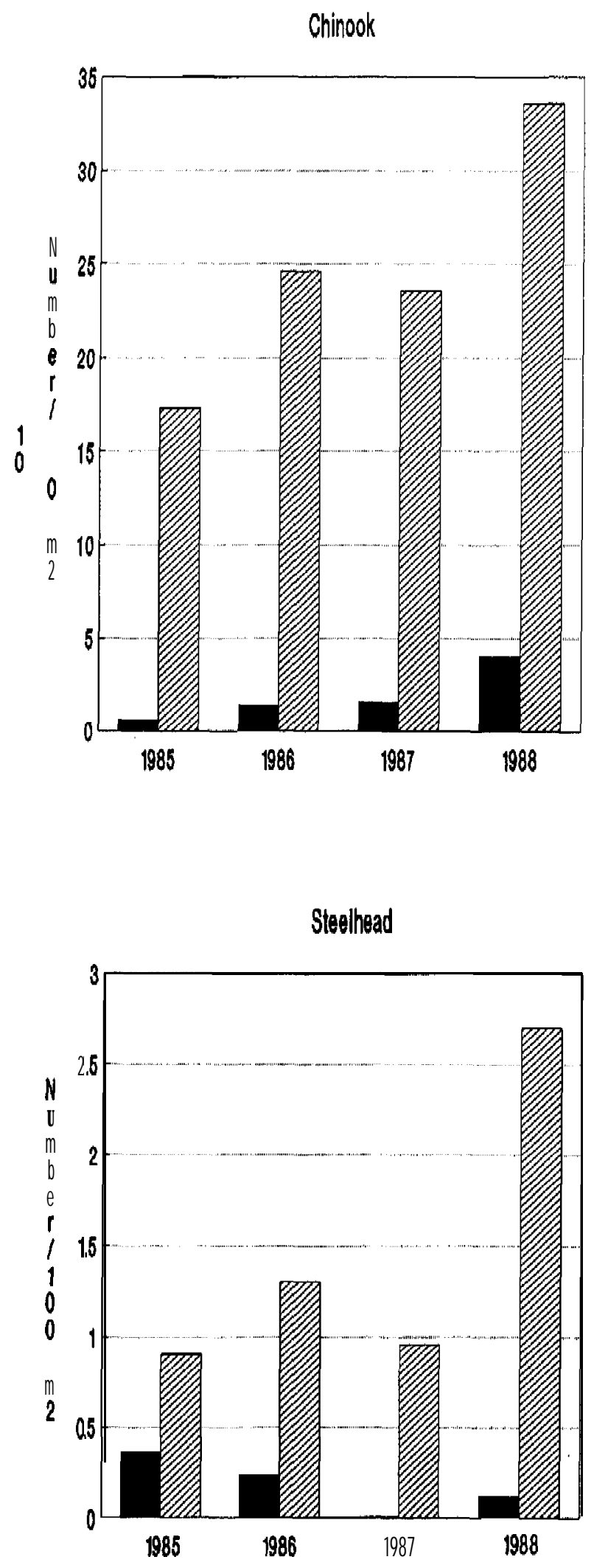

Bear Valley/Ek Cr $\mathbb{Z}$ MFSAControl Streams

Figure 7. Average annual densities of chinook and steelhead parr in the heavily sedimented Bear Valley/Elk Creek drainage and Middle Fork Salmon River control streams. 


\section{Parr Density Monitoring}

\section{Steelhead Parr Monitoring}

Mean annual steelhead parr densities ranged from 2-3 times greater in B channels than $\mathrm{C}$ channels during 1984-88 (Figure 8). Mean steelhead parr (ages$1+$ and $-2+)$ densities in $B$ channels $\left(6.1 / 100 \mathrm{~m}^{2}\right)$ and $C$ channels $\left(2.5 / 100 \mathrm{~m}^{2}\right)$, compared for all monitoring sections from 1984 to 1988 , were significantly different $(p<0.00)$. In areas where steelhead densities were low relative to carrying capacity, steelhead generally occupied preferred habitat. Thus, we suspect that differences in abundance of steelhead parr between years or between drainages may be most evident in B channels when seeding levels are low. With Idaho's generally underseeded steelhead stocks, relatively few steelhead parr inhabit the less preferred $\mathrm{C}$ channel habitat.

The density of age-l+ steelhead probably provides the best estimate of yearclass strength and spawning success the previous year. Age-0+ steelhead still may be emerging from the gravel during the summer survey period (Thurow 1987), and some of the age-2+ steelhead would have already smolted and left the stream. Mature steelhead enter Idaho in the fall and spawn the following spring. Fry emerge that summer and become age-l+ parr a year later.

Mean densities of age-1+ steelhead parr for 1984-88 differed among years ( $F=3.90$, p 0.01 ), with the 1986 density being significantly larger than densities in 1984, 1985, and 1987 (Table 7). Mean densities for ages-l+ and -2+ combined followed a similar pattern, but the only significant annual difference was between $1984\left(2.7 / 100 \mathrm{~m}^{2}\right)$ and $1986\left(7.3 / 100 \mathrm{~m}^{2}\right), \quad(F=2.71, p=0.03)$.

PCC was estimated as the observed density of ages-1+ and $-2+$ steelhead parr divided by the rated carrying capacity, multiplied by 100 . Steelhead PCC differed significantly $(F=2.74, p=0.03)$ between 1984 and 1986 in the 1984-88 analysis.

The yearly comparisons above indicate that densities of steelhead parr were lowest in 1984, increased to the highest level in $1986(7.3 / 100 \mathrm{~m} 2$ and $42.8 \%$ of carrying capacity overall), and have remained stable with an apparent but statistically insignificant decrease by 1988. This same trend is seen with just age-l+ steelhead (Table 7). Because these annual trends incorporate both supplemented and unsupplemented streams and wild and natural A-run and B-run populations, the overall means mask some relationships.

Steelhead Classification-Naturally spawning summer steelhead in Idaho are divided into two groups: A-run and B-run. These groups have been defined traditionally, for Columbia River harvest management, by run timing. A-run steelhead, by the traditional definition, ascended Bonneville Dam on the Columbia River between June 1 and August 25, while B-run steelhead passed Bonneville Dam 

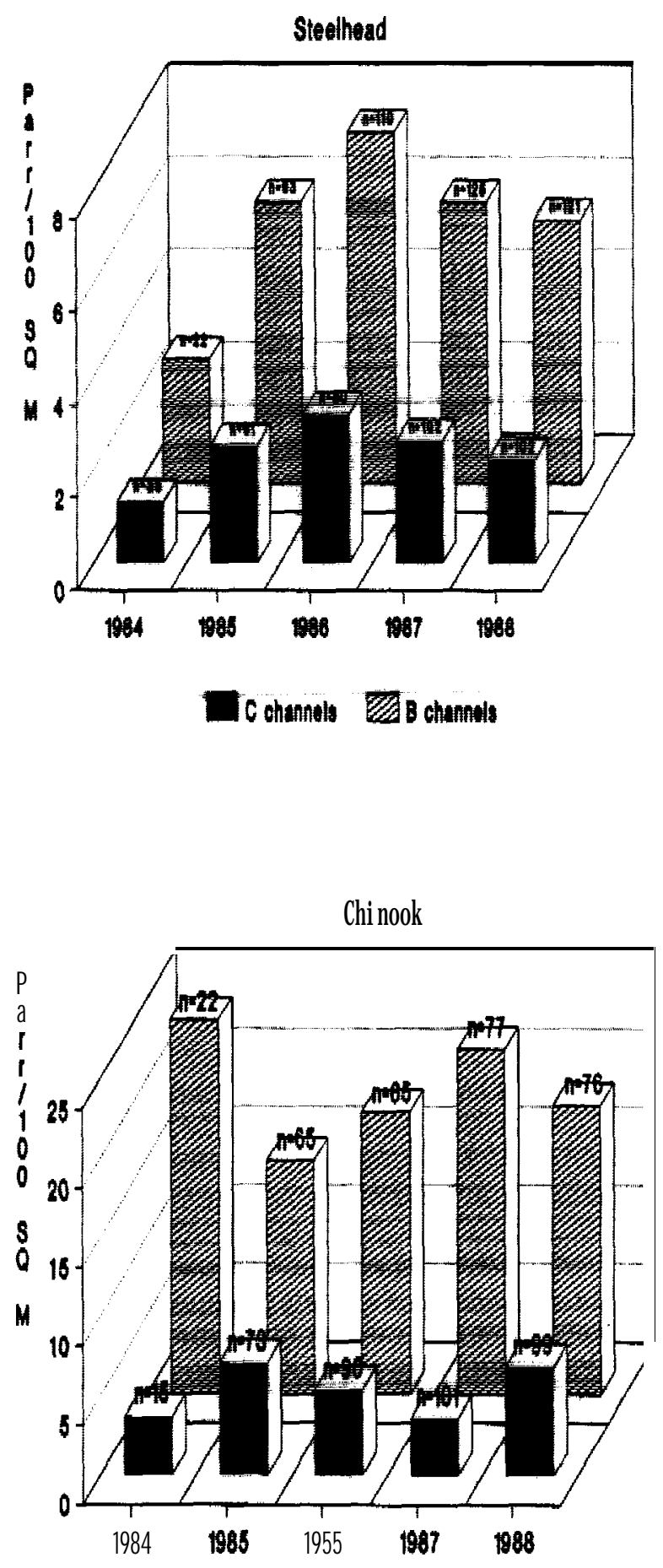

- Echannels $\square$ cchannels

Figure 8. An annual comparison of mean part densities of both chinook (age-0t) and steelhead (ages-1t and $-2+$ ) in $B$ and $C$ channels. 
August 25 and after (TAC 1989). The run-timing differentiation of these two groups has recently become less reliable, primarily due to increased runs of late-entry, hatchery, and natural A-run steelhead into the lower Columbia River.

A-run and B-run steelhead also differ in their adult age and length distributions. A-run steelhead generally have slower ocean growth and spend less time in the ocean than do B-run steelhead. Most A-run steelhead leave the ocean after only one year, while most B-run steelhead spend two years at sea. These differences between runs in time spent in the ocean and ocean-growth rate causes most adult A-run steelhead to be less than $31 \mathrm{l}(77.5 \mathrm{~cm})$ fork length and most B-run steelhead to exceed this length ( $\mathrm{K}$. Ball, IDFG, Personal communication). B-run steelhead predominate in the Clearwater River drainage upstream from Bedrock Creek (RM 25) and in the Middle Fork and South Fork Salmon River drainages. Historically, B-run steelhead may have occupied the upper Salmon River drainage as well (T.C. Bjornn, University of Idaho, personal communication). All other anadromous fish rivers and tributaries in Idaho are classified as A-run. Introduction of B-run steelhead from the Clearwater River's Dworshak Hatchery has occurred in other Salmon River tributaries in recent years, with special emphasis in establishing a population in the East Fork of the Salmon River. The present distribution of wild A-run and B-run steelhead production areas are shown in Figure 9.

Idaho steelhead are further classified as either wild or natural, where wild denotes indigenous, unsupplemented populations. Natural steelhead, in contrast, denote some hatchery background (IDFG 1985). Thus, there are four naturally spawning classes of summer steelhead in Idaho: wild A's, wild B's, natural A's, and natural B's. A fifth class could be called natural AB's, where B-run steelhead from hatcheries have been introduced into streams already containing A-run steelhead.

Mean densities in $B$ channels of these five classes differed significantly ( $p<0.01)$ in 1985-88. The smallest density was for wild B's and the largest density was for wild A's, with the other three classes having intermediate densities (Table 8 ).

The same comparison on an annual basis demonstrated significant differences among class means each year from 1985 through 1988. (The wild A-run class was not sampled in 1984.) The difference in mean density of wild B-run and wild Arun steelhead parr was large and significant in each annual comparison. Annual densities were 3.5 to 6 times greater in wild A-run than wild B-run areas.

The relative densities of wild B-run and wild A-run steelhead parr was even more striking when both $B$ and $C$ channel data were considered together (Table 9, Figure IO). Annual densities were 5 to 8 times greater in wild A-run areas than wild B-run areas. This greater differentiation when both channel types were considered together emphasizes that a relatively smaller percent of wild B-run steelhead parr were being forced out of B channels into available but less desirable C channels.

One-way analyses of variance were used to test for annual density differences for both wild A-run and wild B-run steelhead. Analyses were done 


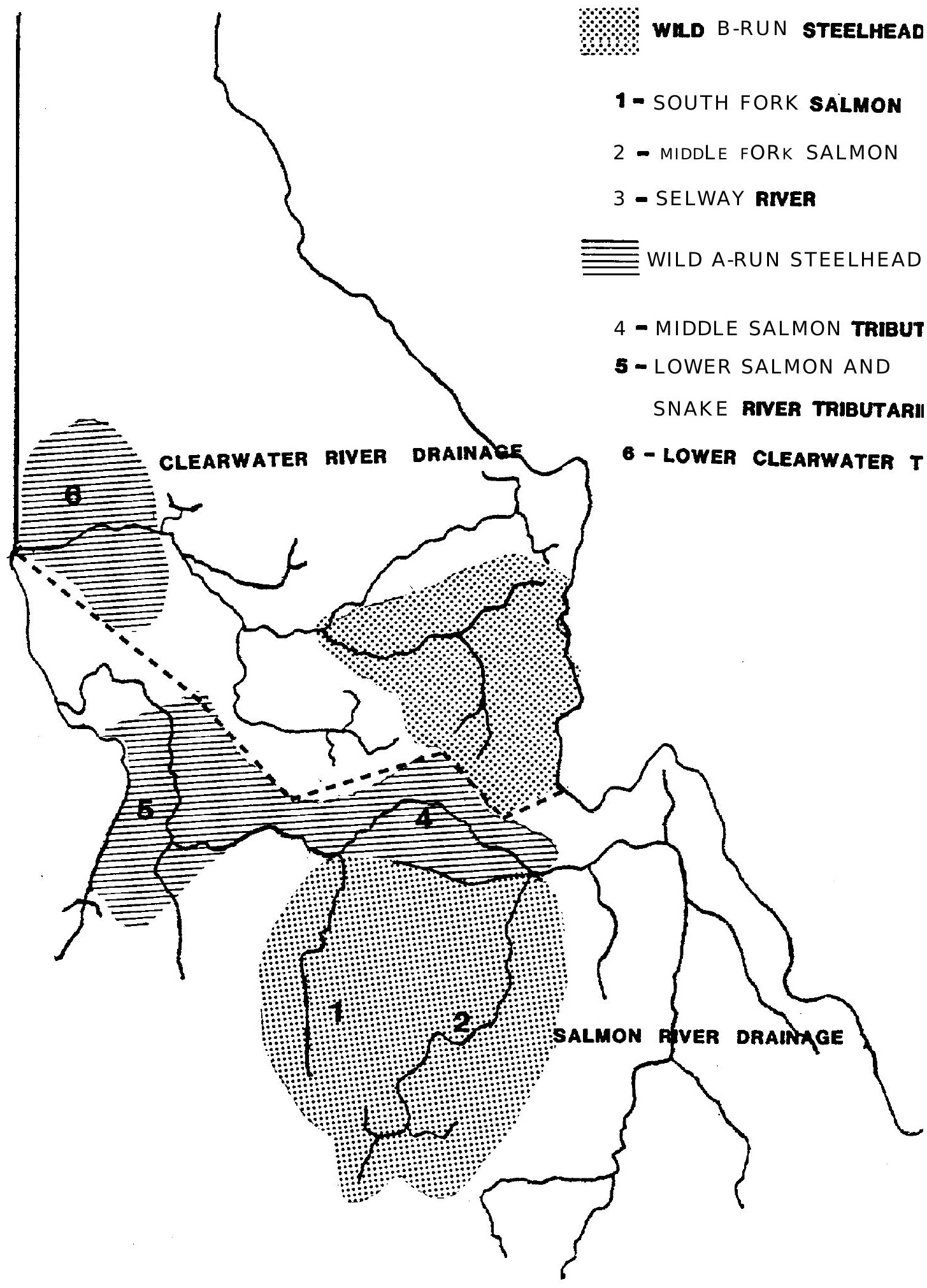

Figure 9. Present distribution of wild A-run and B-run steelhead production areas in Idaho. 
Table 7. Annual means, standard errors and sample sizes for densities and percent carrying capacities (PCC) of ages-It and $-2+$ steelhead parr combined and for densities of age-l+ steelhead alone.

1987

$\frac{\text { Age }-1+\&-2+}{\text { Densities }}$

means

$\mathrm{SE}$

2.7

5.4

7.3

5.4

5.6

0.7

0.8

0.8

0.6

0.6

PCC

$\begin{array}{lrrrrr}\text { Means } & 16.1 & 31.4 & 42.8 & 31.2 & 33.9 \\ \text { SE } & 4.2 & 4.3 & 4.2 & 3.6 & 3.6\end{array}$

Age-1+only

Densities

Means

$\mathrm{SE}$

1.7

3.3

5.2
0.6

3.3

4. 1

n

22

91

108

121

119

Table 8. Annual mean densities (number/100 $\mathrm{m}^{2}$ ) of five classes of age-1+ and -2+ steelhead parr in B channels from 1985 through 1988 .

\begin{tabular}{|c|c|c|c|c|c|}
\hline$\underline{\text { Class }}$ & 1985 & 1986 & 1987 & 1988 & $\begin{array}{l}1985-88 \\
\text { Mean }\end{array}$ \\
\hline Wild B's & 2.6 & $\begin{array}{l}3.5 \\
5.7\end{array}$ & 2.4 & 2.9 & $\begin{array}{l}1.9 \\
4.9\end{array}$ \\
\hline $\begin{array}{l}\text { Nat. } \mathbf{A B}^{\prime} \mathbf{S} \\
\text { Nat. } \mathbf{A}^{\prime} \mathbf{S} \\
\text { Wild } \mathbf{A}^{\prime} \mathbf{S}\end{array}$ & $\begin{array}{r}7.0 \\
6.7 \\
11.3\end{array}$ & $\begin{array}{r}8.4 \\
9.5 \\
15.0\end{array}$ & $\begin{array}{r}6.8 \\
3.8 \\
14.3\end{array}$ & $\begin{array}{r}6.7 \\
10.1 \\
10.4\end{array}$ & $\begin{array}{r}6.8 \\
4.9 \\
12.8\end{array}$ \\
\hline $\mathrm{P}$ & to. 01 & $\mathrm{co} .01$ & to. 01 & $\mathrm{co} 0.01$ & $\mathrm{Co} .01$ \\
\hline
\end{tabular}




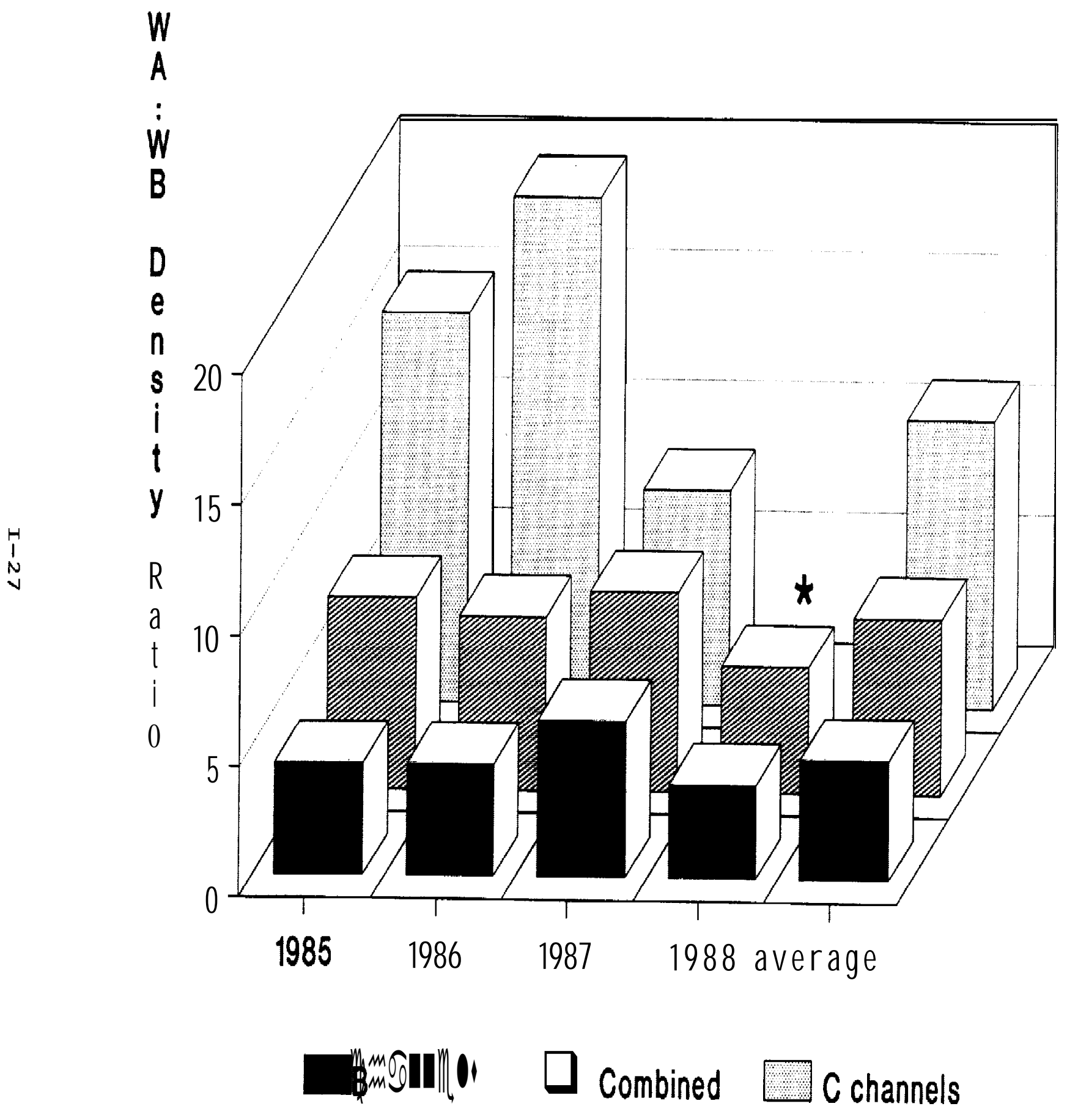

*missing wild group A data

Figure 10. Annual density ratios of wild A-run:wild B-run steelhead by channel type, for ages-1t and 2t, 1985-1988. 
for wild rather than natural steelhead, since wild populations should show the clearest trend in response to spawning escapements.

To eliminate the masking effect on density of parr from two consecutive brood years (age-1+ and $-2+$ ) parr, the analyses were done only on age-1+ parr which generally account for $2 / 3$ of the age-1+ and $-2+$ density. Mean annual densities of wild A-run steelhead ranged from $10.4 / 100 \mathrm{~m}^{2}$ to $15.0 / 100 \mathrm{~m}^{2}$ during 1985-88 (Table 9). Wild B-run steelhead densities ranged from $1.5 / 100 \mathrm{~m}^{2}$ to 2.3/100 $\mathrm{m}^{2}$ during 1984-88. Within groups, densities did not differ significantly among years at the 0.05 level using one-way analysis of variance (Table IO).

Drainacre and Group Catesories-We partitioned steelhead streams into 12 divisions or cells, considering classes (wild and natural, and A-run and B-run combinations) and drainages. The cells were:

\section{Wild B-run}

1. Selway River and its tributaries.

2. Middle Fork Salmon River tributaries.

3. South Fork Salmon River and its tributaries.

\section{Natural B-run}

4. Lochsa River and its tributaries.

5. South Fork Clearwater River tributaries.

6. Lolo Creek and its tributary, Eldorado Creek.

\section{Natural AB}

7. Little Salmon River and its tributary, Hazard Creek; Slate Creek and the East Fork Salmon River.

\section{Natural A-run}

8. Upper Salmon River and its tributaries.

9. North Fork Salmon, Pahsimeroi, and Lemhi Rivers and the latter's tributaries, and Panther Creek and its tributary, Moyer Creek.

10. Snake River tributaries of Captain John and Granite Creeks and the Little Salmon River tributary of Boulder Creek.

\section{Wild A-run}

11. Middle Salmon River tributaries of Bargamin, Chamberlain, Horse, and Sheep Creeks.

12. Snake River tributaries of Sheep and Wolf Creeks; the lower Clearwater River tributary of Big Canyon Creek; the lower Salmon River tributary of Whitebird Creek; and the Little Salmon River tributary of Rapid River.

Mean densities and sample sizes for age-1+ and $-2+$ steelhead parr in each cell for 1984 through 1988 in B channels are presented in Table 11. No annual 
Table 9. Annual mean densities of wild A-run and wild B-run steelhead parr for all (both $B$ and $C$ channels) monitoring sections and the annual ratio of wild A-run to wild B-run densities from 1985 to 1988 .

\begin{tabular}{lcccc}
\hline & 1985 & 1986 & 1987 & 1988 \\
\hline $\begin{array}{l}\text { Mean Wild A } \\
\text { Density }\end{array}$ & 11.2 & 15.0 & 13.6 & 10.4 \\
$\begin{array}{l}\text { Mean Wild B } \\
\text { Density }\end{array}$ & 1.5 & 2.3 & 1.7 & 2.2 \\
$\begin{array}{l}\text { Wild A:Wild B } \\
\text { Density Ratio }\end{array}$ & 7.3 & 6.6 & 8.2 & 4.8 \\
\hline
\end{tabular}

Table 10. Results of one-way analyses of variance on age-l+ wild steelhead mean densities for all wild A-run and B-run parr and for those groups in B channels only.

\begin{tabular}{|c|c|c|c|}
\hline $\begin{array}{l}\text { Group } \\
\text { Analvsed } \\
\end{array}$ & $\begin{array}{c}\text { Years } \\
\text { Compared }\end{array}$ & $\begin{array}{l}\text { Probability of } \\
\text { Wisher F-value }\end{array}$ & Significance \\
\hline $\begin{array}{l}\text { All wild } \mathbf{A}^{\prime} \mathbf{s} \\
\text { All wild B's }\end{array}$ & $\begin{array}{l}1985-88 \\
1984-88\end{array}$ & $\begin{array}{l}0.198 \\
0.091\end{array}$ & $\begin{array}{l}\text { NS } \\
\text { NS }\end{array}$ \\
\hline $\begin{array}{l}\text { B channels } \\
\text { Wild B's in }\end{array}$ & $1985-88$ & 0.280 & NS \\
\hline B channels & $1984-88$ & 0.537 & NS \\
\hline
\end{tabular}


Table 11. Mean densities (number/100 $\mathrm{m}^{2}$ ) and sample sizes (in parentheses) of age-1+ and $-2+$ steelhead parr in 12 cells encompassing

Idaho's anadromous fish waters, in B channels.

\begin{tabular}{|c|c|c|c|c|c|}
\hline $\begin{array}{ll}\text { Cell Class } \\
\end{array}$ & 1984 & 1985 & 1986 & 1987 & 1988 \\
\hline 1. & & $1.2(10)$ & $0.8 \quad(9)$ & (13) & (12) \\
\hline 2. & & $3.6(17)$ & $5.0 \quad(20)$ & (19) & (18) \\
\hline 3. & $3.6 \quad(3)$ & $0.3 \quad(1)$ & $3.0 \quad(13)$ & (13) & (15) \\
\hline
\end{tabular}

Natural B-run
4.
3.7 (3)
0.9 (5)
1.0 (5)
$1.2(5)$
$2.4 \quad(5)$
5.
$0.4(5)$
$1.5(7)$
$6.6 \quad(10)$
6.0 (8)
8.0 (19)
6.
$6.4(2)$
3.3 (4)
$8.0(6)$
6.9 (6)
6.1 (6)

Natural $\mathbf{A B}^{\prime} \mathbf{S}$

7.

$\begin{array}{llll}7.0 & (7) \quad 8.4 \quad(7)\end{array}$

6.7 (9)

10.1 (3)

Natural A-run

$\begin{array}{ccccccccccc}\text { 8. } & 0.3 & (4) & 2.3 & (11) & 3.5 & (6) & 0.4 & (17) & 1.9 & (17) \\ 9 . & 0.4 & (2) & 5.1 & (5) & 4.0 & (5) & 2.7 & (5) & 3.7 & (5) \\ 10 . & 7.2 & (3) & 13.7 & (8) & 18.4 & (7) & 11.7 & (8) & 20.0 & (6)\end{array}$

Wild A-run
11.
$\begin{array}{llllllll}5.6 & (7) & 13.3 & (10) & 15.8 & (10) & 8.2 & (8)\end{array}$
12.
$\begin{array}{llllllll}15.8 & \text { (9) } & 16.6 & (10) & 12.8 & \text { (10) } & 13.9 & \text { (5) }\end{array}$ 
trend in wild steelhead density was apparent during the period (Figure 11). There was an obvious difference, however, in the densities of wild A-run and wild B-run steelhead, which was consistent among cells for each classification. The three wild B-run cells had consistently low densities, while both wild Arun cells had consistently higher densities.

There was no consistent difference between natural A-run and natural B-run steelhead parr densities (Figure 12) because differences in supplementation masked differences in escapement. There was no obvious density trend through time in any cell. The natural A-run cell (10) from the snake River tributaries of Sheep and Captain John Creek and the Little Salmon River tributary of Boulder Creek has had little direct supplementation, and densities there were similar to those in wild A-run streams.

With the exception of the upper Salmon River, the areas with highest densities generally had A-run steelhead. One-way analysis of variances done separately for each year from 1985 through 1988 showed highly significant differences between cells of age-l+ steelhead in B channels (Table 12). Density of wild A's from the Snake, lower Salmon, and Clearwater Rivers were always significantly greater than any of the three drainages containing wild B's. Densities of natural A's from the Snake and lower Salmon Rivers were also significantly greater than densities in wild B drainages, except in 1987. All A-run steelhead drainages, except for the upper Salmon River, generally had higher densities than wild B steelhead drainages.

Densities of natural A-run steelhead parr in the upper Salmon River may be depressed for several reasons. The former Sunbeam Dam, near the mouth of the Yankee Fork, may have eliminated part of the genetic component of the upriver steelhead run that arrived at the dam when extreme high or low river discharges created a migration barrier. The stock of A-run steelhead used to supplement the upper Salmon River was not the indigenous stock, but rather was taken from the Snake River in Hells Canyon, just prior to the elimination of that stock's spawning and rearing area by the construction of Idaho Power's Hells Canyon dam complex. The donor stock may have had ecological requirements not well satisfied by the high elevation of upper Salmon River drainage. Finally, much of the upper Salmon River watershed is intensively managed for cattle production and suffers the associated negative effects of riparian grazing and irrigation withdrawals (Kiefer and Forster 1990).

Although none of the mean densities for B-run steelhead approach the highest densities seen for A-run steelhead, the difference appears to be due to escapements rather than to group-specific carrying capacities. Maximum densities for combined age-1 + and -2+ B-run steelhead parr in some natural productions areas of the South Fork Clearwater River drainage and some wild production areas of the Middle Fork Salmon River drainage have approached or exceeded the theoretical maximum density of $20 / 100 \mathrm{~m}^{2}$ in $\mathrm{B}$ channels and $14 / 100$ $\mathrm{m}^{2}$ in C channels (Table 13).

The extremely depressed densities in all wild B-run drainages exist even in pristine drainages and despite termination of sport harvest of wild steelhead in Idaho in the Salmon and Snake Rivers in 1982 and the Clearwater River in 


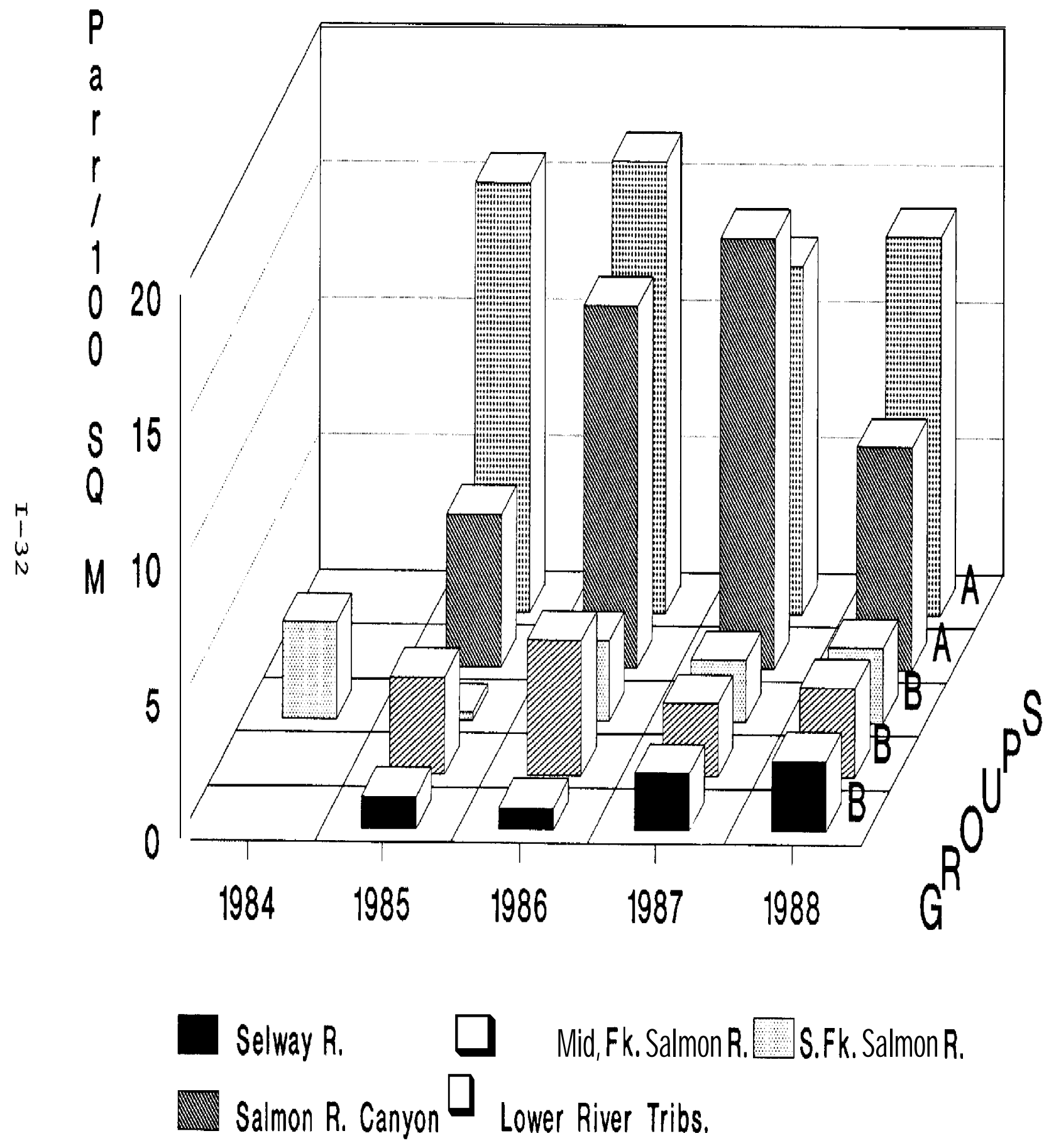

Figure 11, Mean annual densities of age-1+ and -2+ wild steelhead parr in two A-run areas and three B-run areas, in B channels, 1984.1988, 


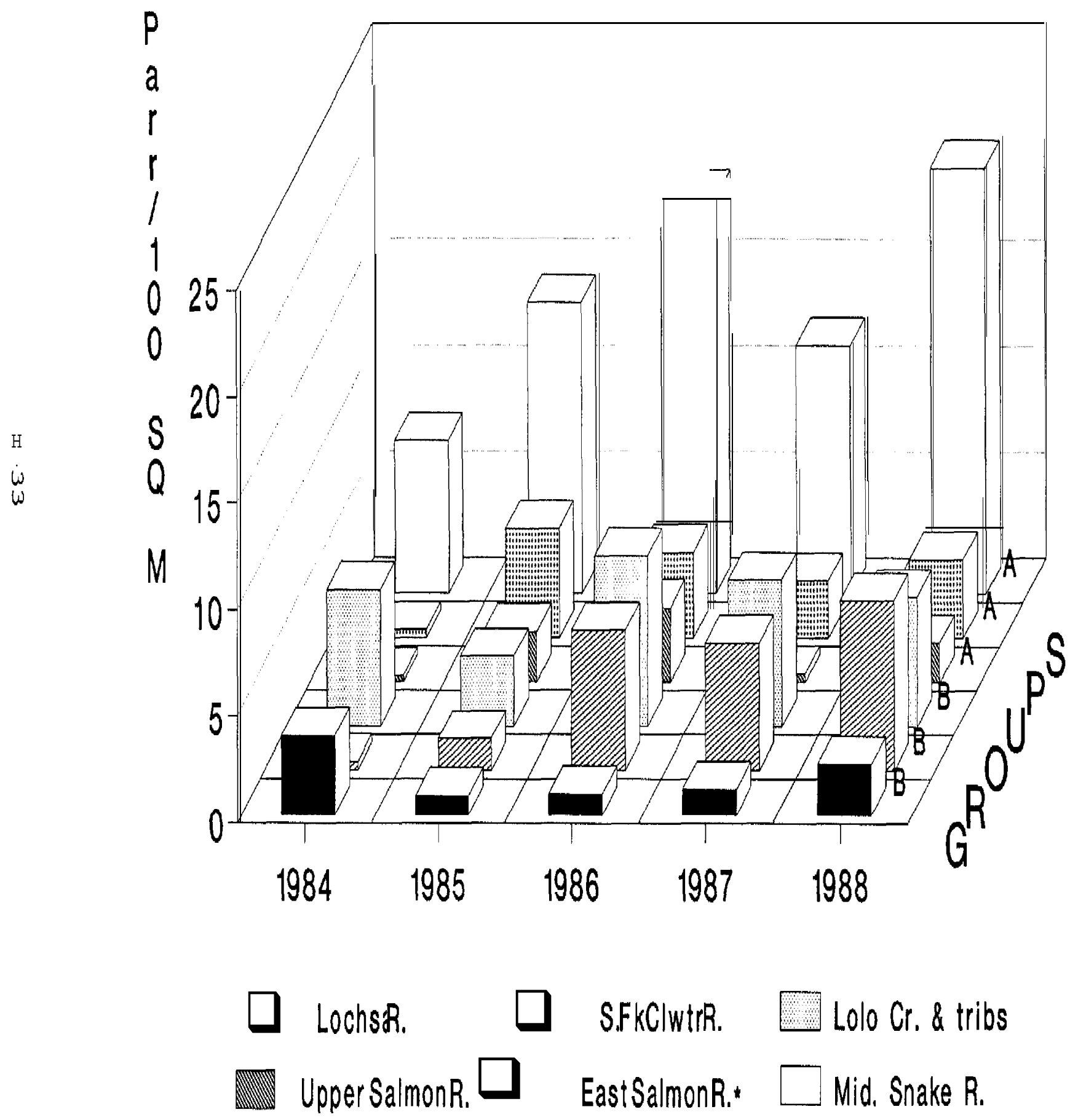

Figure 12. Mean annual densities of age-lt and -2-t natural steelhead parr in three A-run areas and three B-run areas, in B channels, 1984-1988. *The East Salmon River includes tributaries from Panther Creek through Pahsimeroi River, 
Table 12. Mean annual densities (number/100 $\mathbf{m}^{2}$ ) of age-l+ steelhead parr in B channels from 1985 through 1988. There were highly significant differences between mean cell densities within each year.

\begin{tabular}{|c|c|c|c|c|c|c|c|}
\hline \multirow[b]{2}{*}{ Cell } & \multirow[b]{2}{*}{ Drainaqe } & \multirow{2}{*}{\multicolumn{2}{|c|}{ Class }} & \multirow{2}{*}{1985} & \multicolumn{2}{|c|}{$\begin{array}{l}\frac{\text { Densities }}{1986} 1987 \\
1986\end{array}$} & \multirow[b]{2}{*}{1988} \\
\hline & & & & & 1986 & 1987 & \\
\hline 1. & Selway R. & Wild & $B^{\prime} s$ & 0.6 & 0.6 & 0.8 & 1.9 \\
\hline 2. & Salmon R., M. Fk. & $"$ & $"$ & 2.3 & 2.8 & 1.4 & 2.0 \\
\hline 3. & Salmon R., S. Fk. & $"$ & " & 1.9 & 1.9 & 1.4 & 2.0 \\
\hline 4. & Lochsa R., & Nat. & $B^{\prime} S$ & 0.3 & 0.7 & 0.8 & 1.6 \\
\hline 5. & Clearwater R, S. Fk & $"$ & $"$ & 0.8 & 6.2 & 4.7 & 7.4 \\
\hline 6. & Lolo Cr. & $"$ & $"$ & 2.0 & 7.2 & 5.5 & 5.0 \\
\hline 7. & $\begin{array}{l}\text { E. Fk \& L. Salmon } \\
\text { R. \& Slate Cr. }\end{array}$ & Nat. & $A B^{\prime} S$ & 3.6 & 5.6 & 3.7 & 7.0 \\
\hline 8. & Upper Salmon R. & Nat. & $A^{\prime} s$ & 1.7 & 2.8 & 0.2 & 1.4 \\
\hline 9. & $\begin{array}{l}\text { Pahsimeroi, Lemhi } \\
\text { N. Fk Salmon R. }\end{array}$ & $"$ & $"$ & 4.4 & 3.0 & 1.8 & 2.7 \\
\hline 10 . & $\begin{array}{l}\text { Snake \& Lower } \\
\text { Salmon R. tribs. }\end{array}$ & & $"$ & 9.7 & 13.9 & 7.9 & 12.6 \\
\hline 11. & Mid-Salmon R. Tribs & Wild & $A^{\prime} S$ & 2.0 & 6.9 & 7.0 & 5.2 \\
\hline 12 . & $\begin{array}{l}\text { Clearwater R. Tribs, } \\
\text { Hells Canyon, } \\
\text { Lower Salmon }\end{array}$ & , & $"$ & 9.0 & 12.5 & 8.8 & 9.0 \\
\hline
\end{tabular}


1986. The majority of the Selway and Middle Fork Salmon River drainages are in wilderness and have experienced only localized damage from land use practices.

\section{Chinook Parr}

Wild, indigenous chinook populations in Idaho presently occur in the entire Middle Fork Salmon River drainage, as well as in a few smaller salmon River tributaries (Figure 13). The remainder of Idaho's chinook salmon waters are classified as natural populations.

There are two races of chinook, spring and summer, which have parr that rear one year in Idaho streams. These two chinook races have similar life histories. Spawning occurs in August-September, with emergence in early spring, The parr rear one year in tributaries and main stems and smolt the following April-May. A third race, fall chinook, produce sub-yearling smolts from spawning areas in lower, main stem rivers and are not monitored by this project.

We identified four classes of chinook, wild spring, wild summer, natural spring, and natural summer, in our monitoring areas. Because of small sample sizes of summer chinook (Table 14), we pooled spring and summer chinook data and compared wild and natural chinook production.

Chinook parr prefer the pool habitat of low gradient, meandering streams (C channels). Average density of chinook parr in C channels for 1985-88 was $18.2 / 100 \mathrm{~m}^{2}, 3.5$ times greater than the mean of 5.2 in $B$ channels. PCC in $B$ and $\mathrm{C}$ channels were $9.2 \%$ and $22.4 \%$, respectively. Both of these indicated severely depressed populations. Mean PCC for B channels was significantly lower $(\mathrm{p}=0.01)$, indicating that at low seeding levels there was little need for chinook parr to occupy the less desirable B channels. Average annual density of chinook parr in C channels ranged from 14.6 in 1985 to 20.6 in 1987 with no significant differences between years $(p=0.34)$.

Wild verses Natural Production-We classified chinook monitoring data for 1985-88 as either wild or natural and did two-way AOV for both density and PCC on: 1) all sections, 2) B channel sections, and 3) C channel sections. Factors in the analyses were year and production class (wild or natural).

There were no significant differences between years for any of the six analyses (Table 15). For both density and PCC, means for natural production were significantly higher than for wild production areas for $B$ and $C$ channels combined and for B channels alone, but not for C channels alone.

These analyses imply that there has been no trend in 1985-88 of either rebuilding or decline for chinook parr density or PCC. Additionally, both density and PCC were significantly higher for natural than wild chinook parr where all sections and B channels alone were considered. Where only the preferred C channel sections were considered, differences between the wild and 


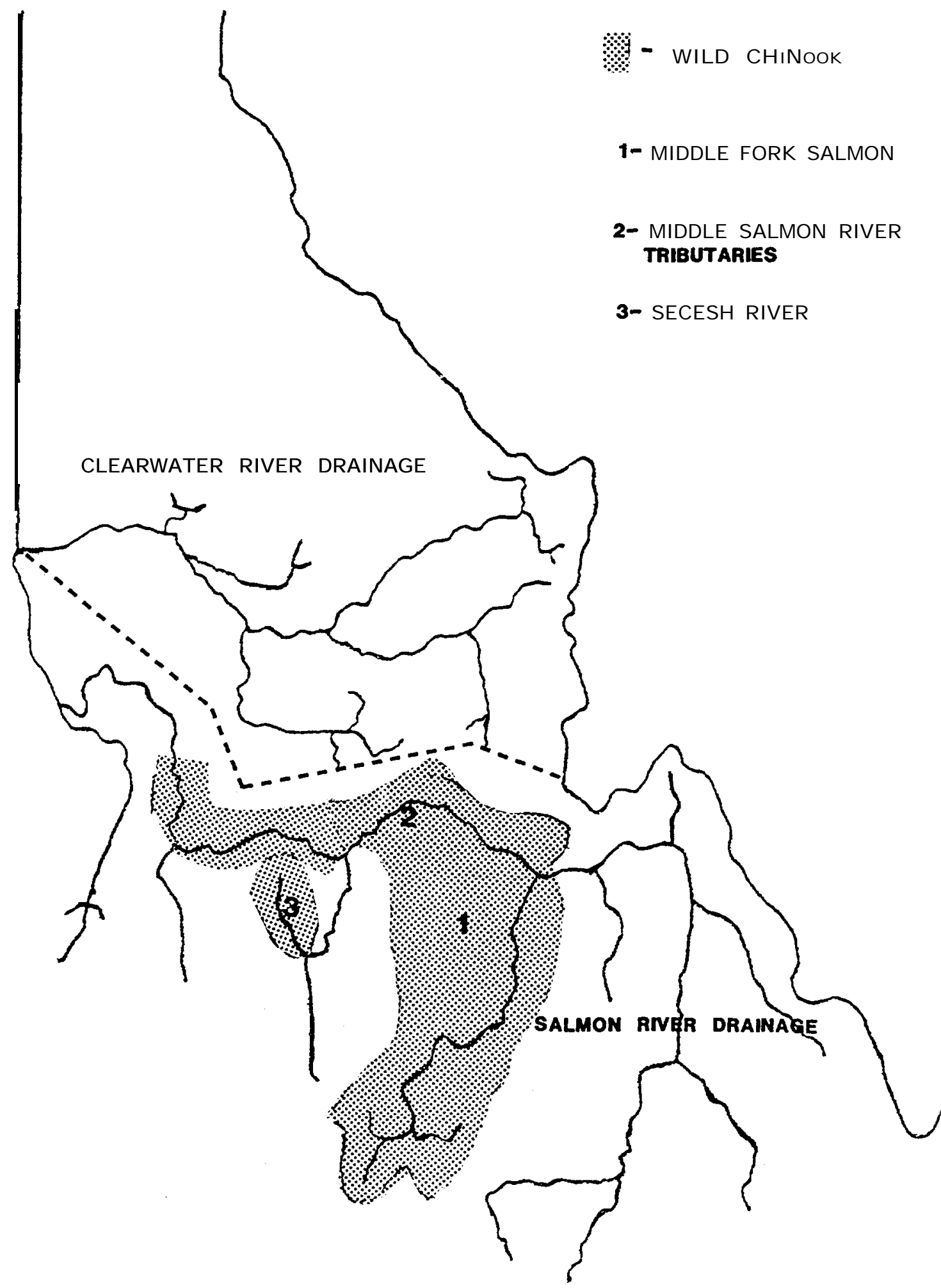

Figure 13. Present distribution of wild chinook production areas in Idaho. 
Table 13. Streams, stratum-section locations, channel types, years sampled and densities recorded for ages-1+ and $-2+$ steelhead parr for samples where densities have exceeded $75 \%$ of rated carrying capacities in streams with B-run steelhead stocks.

\begin{tabular}{lccccc}
\hline Stream & Stratum & Section & $\begin{array}{c}\text { Channel } \\
\text { Type }\end{array}$ & Year & $\begin{array}{c}\text { Ages-1+ \& -2+ } \\
\text { Density }\end{array}$ \\
\hline Loon Cr. & & L1 & B & 1986 & 17.6 \\
Big Cr. & Lower & L1 & B & 1986 & 16.2 \\
Big Cr. & Lower & L1 & B & 1987 & 16.1 \\
Crooked R. & 2 & Trt2 & B & 1987 & 19.5 \\
Crooked R. & 2 & Trt2 & B & 1988 & 15.5 \\
Relief Cr. & 2 & Relief2 & B & 1986 & 16.5 \\
Red R. & 5 & Ctrl2 & C & 1986 & 19.1 \\
Red R. & 5 & Trt2 & C & 1986 & 11.4 \\
Amer. R. & & 1 & C & 1986 & 10.7 \\
Amer. R. & & 2 & C & 1986 & 16.7 \\
Amer. R. & & 2 & C & 1987 & 14.5 \\
Meadow Cr. Mdw & & Grazed & C & 1987 & 15.0 \\
Relief Cr. & 2 & Relief & C & 1988 & 26.7 \\
\hline
\end{tabular}

Table 14. Number of monitoring sections for four classes of chinook salmon parr.

\begin{tabular}{lr}
\hline Classes & $\mathrm{n}$ \\
\hline Wild Spring Chinook & 65 \\
Wild Summer Chinook & 8 \\
Natural Spring Chinook & 107 \\
Natural Summer Chinook & 19 \\
\hline
\end{tabular}


Table 15. Mean annual chinook densities (number/100 $\mathrm{m}^{2}$ ) and percents of carrying capacity (PCC) for all monitoring sections and separately for $B$ and $C$ channel sections. Probabilities of mean values being significantly different between years and between classes are included.

\section{5}

\section{6}

\section{Densities}

All sections (mean comparisons: years $p=0.89, W / N p=0.02$ )

$\begin{array}{lrlrlrrrr}\text { Wild } & 6.7 & (60) & 7.8 & (69) & 11.0 & (75) & 9.1 & (61) \\ \text { Natural } & 12.9 & (84) & 12.1 & (92) & 11.4 & (108) & 12.3 & (119)\end{array}$

B Channels (mean comparisons: years $\mathrm{p}=0.59, \mathrm{~W} / \mathrm{N} \mathrm{p}=0.00$ )
Wild
$2.5 \quad(34)$
$2.9 \quad(41)$
$6.8 \quad(54)$
$2.0 \quad(42)$
3.1 (31)
Natural

$9.9 \quad(44)$
4.5
(63)
7.2 (73)

C Channels (mean comparisons: years $\mathrm{p}=0.29, \mathrm{~W} / \mathrm{N} \mathrm{p}=0.27$ )

$\begin{array}{lllllllll}\text { Wild } & 12.2 & (26) & 14.9 & (28) & 22.4 & (33) & 15.3 & (30) \\ \text { Natural } & 16.2 & (40) & 19.6 & (38) & 21.0 & (45) & 20.3 & (46)\end{array}$

$\underline{\text { PCC }}$

All Sections (mean comparisons: years $p=0.92, w / N p=0.00$ )
Wild
7.8
10.7
Natural
17.2
12.8
16.4
12.8
18.4

B Channels (mean comparisons: years $\mathrm{p}=0.59, \mathrm{~W} / \mathrm{N} \mathrm{p}=0.00$ )
Wild
3.8
5.6
3.7
6.0
Natural
11.5
8.4
13.2

C Channels (mean comparisons: years $\mathrm{p}=0.36, \mathrm{~W} / \mathrm{N} \mathrm{p}=0.06$ )
Wild
13.2
18.2
24.5
27.6
16.8
Natural
25.4
26.6 
natural means were not significant, although the differences for PCC was nearly significant $(p=0.06)$.

Mean annual densities for wild chinook parr in $C$ channels ranged from

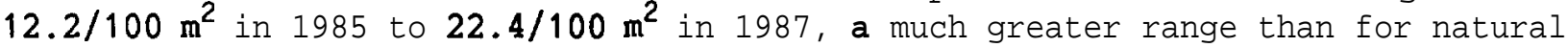
chinook parr, i.e., 16.2 in 1985 to 21.0 in 1987. Mean annual PCC for wild chinook parr in C channels ranged from 13.2\% in 1985 to 24.5\% in 1987.

Although annual differences were not significant, mean values fluctuated more for wild than natural populations. Natural population abundance was affected by varying levels of hatchery plants of fry, eggs, and adults. Densities and PCC in wild areas, in contrast, should be strongly influenced by redd density, outmigration flow/passage conditions, and harvest.

Class and Drainage Cells-We assigned Idaho's chinook production areas to 13 cells based on geographical distribution and their wild or natural status. The cells are as follows:

$\underline{\text { Cell }}$

Location/Description

1. Middle Fork Salmon R. tributaries

(without Bear Valley Cr. drainage)

2. Lower reaches of the Salmon R. Canyon

tributaries

3. All wild summer chinook areas

(from Mid. Fk, S. Fk and Main Salmon R.)

4. Chamberlain Basin

5. Bear Valley $\mathrm{Cr}$. and its tributaries

6. Upper Salmon R. and E. Fk. Salmon R.

7. Pahsimeroi, Lemhi and $\mathbf{N}$. Fk. Salmon R. and Panther $\mathrm{Cr}$.

8. South Fork Salmon River

9. Little Salmon River

10. Selway River

11. Lochsa River

12. South Fork Clearwater River

13. Lo10 Creek and tributaries
Wild/Natural

Wild

Wild

Wild

Wild

Wild

Natural

Natural

Natural

Natural

Natural

Natural

Natural

Natura 1 
The mean PCC for 1985-88 ranged from $1.5 \%$ in the wild chinook production area of lower reaches of the middle Salmon River canyon (cell 2) to $40.1 \%$ in the heavily supplemented South Fork Clearwater River tributaries (cell 12) (Table 16). However, poor and moderate levels of production were observed in both wild and natural cells (Figures 14 and 15). The lowest PCC among natural production areas occurred in the Selway (2.1\%) and Lochsa (2.9\%) drainages, both tributaries of the Clearwater River.

The entire Clearwater River drainage lost all but remnant chinook salmon populations due to inadequate adult passage facilities at the Washington Water Power (WWP) dam near the river mouth. The dam was removed in 1973 after operating 47 years. The Selway chinook population was reestablished from a combination of wild fish transfers and hatchery stocking from the 1960s until 1981, with an additional stocking in 1985 (Lindland and Bowler 1986). There was no chinook supplementation in the Lochsa drainage from 1980 through 1986. Recent Lochsa drainage fry plants were not near the parr monitoring sections and should not have influenced the observed densities.

The wild production area of Bear Valley Creek and its tributaries, Elk and Bearskin Creeks (cell 5), were affected by loss of riparian cover, stream bank instability and sedimentation resulting from cattle grazing (OEA 1987b). Additionally, placer mining, which occurred prior to the mid-1950s (Konopacky et al. 1985) contributed substantially to Bear Valley Creek sedimentation. This was the only cell in which chinook parr density was higher in B channels than in $\mathrm{C}$ channels and may reflect fish response to the extreme sedimentation in the depositional $\mathrm{C}$ channels. The Bear Valley drainage had among the lowest average chinook parr density $\left(2.2 / 100 \mathrm{~m}^{2}\right)$, and its average PCC was $4.0 \%$.

The highest PCC in natural production areas occurred in Lo10 Creek (24.8\%) and the South Fork Clearwater River tributaries (40.1\%), areas which were heavily supplemented with fry during the study. Highest mean PCC in wild production areas were in Chamberlain Basin (30.5\%) and the Middle Fork Salmon River tributaries (17.5\%), areas which have been least affected by land and water uses and contain large areas of $\mathrm{C}$ channel spawning and rearing habitat. Although there are trends apparent in the annual mean values within several of the cells (Table 17), simple linear regression of PCC on years did not produce any significant regressions among the 13 cells. There is insufficient evidence to demonstrate a trend in chinook PCC from 1985 to 1988 in any of the cells.

It is not possible to determine how populations of chinook fared in areas where intense supplementation has occurred in recent years because of continual additions of hatchery fish in natural production areas (e.g., South Fork Clearwater and South Fork Salmon rivers and Lo10 Creek). However, it is apparent that in unsupplemented or lightly supplemented drainages, the level of seeding relative to carrying capacities was extremely low.

Wild chinook populations in good to excellent habitat achieved 18-30\% of carrying capacities. In areas a few kilometers from the spawning sites, such as the lower reaches of the Salmon River canyon tributaries, few parr were 
Table 16. Mean chinook parr densities (number/100 $\mathrm{m}^{2}$ ) and percent carrying capacities (PCC) for chinook parr in $13 \mathrm{class} /$ drainage cells, from 1985 through 1988. Sample sizes are in parentheses.

\begin{tabular}{|c|c|c|c|c|}
\hline Cell & $\begin{array}{l}\text { Production } \\
\text { Class }\end{array}$ & $\begin{array}{c}\text { All } \\
\text { Sections }\end{array}$ & $\begin{array}{l}\text { B Channel } \\
\text { sections }\end{array}$ & $\begin{array}{r}\text { Channel } \\
\text { Sections } \\
\end{array}$ \\
\hline \multicolumn{5}{|c|}{ Densities } \\
\hline $\begin{array}{r}1 \\
2 \\
3 \\
4 \\
5 \\
6 \\
7 \\
8 \\
9 \\
10 \\
11 \\
12 \\
13\end{array}$ & $\begin{array}{l}\text { Wild } \\
\text { Wild } \\
\text { Wild } \\
\text { Wild } \\
\text { Wild } \\
\text { Natural } \\
\text { Natural } \\
\text { Natural } \\
\text { Natural } \\
\text { Natural } \\
\text { Natural } \\
\text { Natural } \\
\text { Natural }\end{array}$ & $\begin{aligned} 14.7 & (119) \\
0.7 & (52) \\
9.2 & (20) \\
25.1 & (10) \\
2.3 & (41) \\
10.2 & (115) \\
6.5 & (44) \\
13.9 & (44) \\
5.5 & (27) \\
1.7 & (48) \\
2.1 & (20) \\
26.2 & (80) \\
17.9 & (25)\end{aligned}$ & $\begin{array}{rc}3.9 & (59) \\
0.7 & (52) \\
2.1 & (8) \\
15.2 & (6) \\
3.3 & (3) \\
5.1 & (38) \\
5.1 & (12) \\
5.5 & (33) \\
& \\
5.5 & (27) \\
0.9 & (44) \\
19.8 & (42) \\
6.3 & (18)\end{array}$ & $\begin{array}{cc}25.3 & (60) \\
\star & \\
14.0 & (12) \\
40: 0 & (4) \\
2.2 & (38) \\
12.7 & (77) \\
7.0 & (32) \\
38.9 & (11) \\
\star & \\
11.0 & (4) \\
\star & \\
33.3 & (38) \\
47.9 & (7)\end{array}$ \\
\hline
\end{tabular}

\section{Percent of Carrving Capacities}

$\begin{array}{rlrrr} & & 7.3 & 27.6 \\ \text { a } & \text { Wild Wild } & 17.51 .5 & 1.5 & \star \\ 3 & \text { Wild } & 11.5 & 3.1 & 17.0 \\ 4 & \text { Wild } & 30.5 & 25.5 & 38.0 \\ 5 & & 4.0 & \mathbf{4} .3 & 4.0 \\ 6 & \text { Nild Natural } & 11.9 & 6.4 & 14.6 \\ 7 & \text { Natural } & \mathbf{7 . 2} & 6.6 & \mathbf{7} .4 \\ 8 & \text { Natural } & \mathbf{2 3 . 6} & \mathbf{9 . 7} & \mathbf{6 5 . 0} \\ 9 & \text { Natural } & 12.5 & \mathbf{1 2 . 5} & \star \\ 11 & \text { Natural } & 2.1 & 1.3 & 10.2 \\ 12 & \text { Natural Natural } & 40.12 .9 & 2.9 & \star \\ 13 & \text { Natural } & 24.8 & \mathbf{3 6 . 2} & \mathbf{4 4 . 4} \\ 13 & & \mathbf{1 0 . 2} & \mathbf{6 2 . 2}\end{array}$

$\star=$ No sections with $C$ channels. 


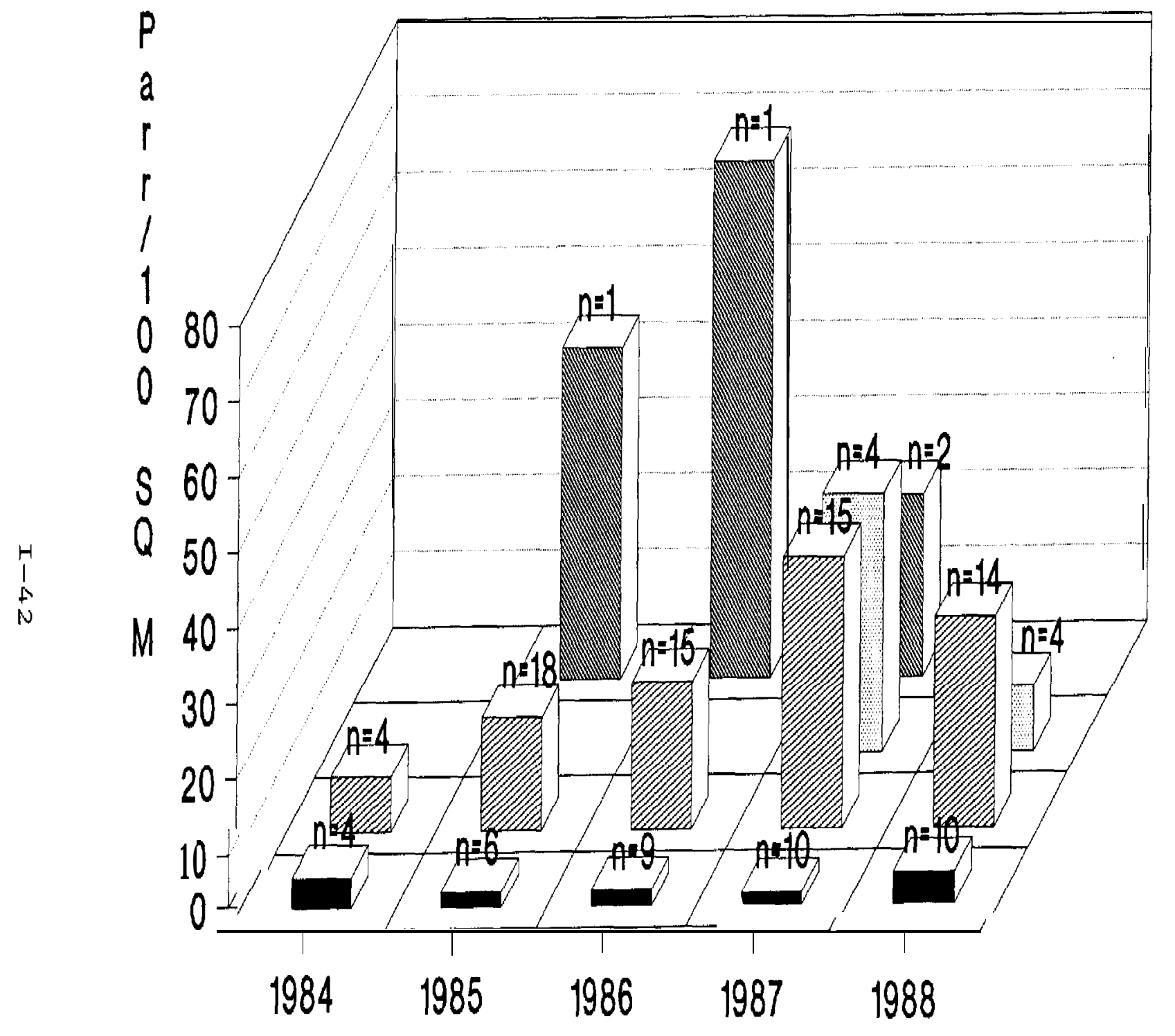

Bear Valley/Ekk Cr. $\square$ M.Fk.SalmonTribs.

$\square$ Wild Summer Chinook Chamberlain Basin

Figure 14. Mean annual densities of age-0t chinook parr in C channels in four wild chinook productionareas, 1984-1988. 

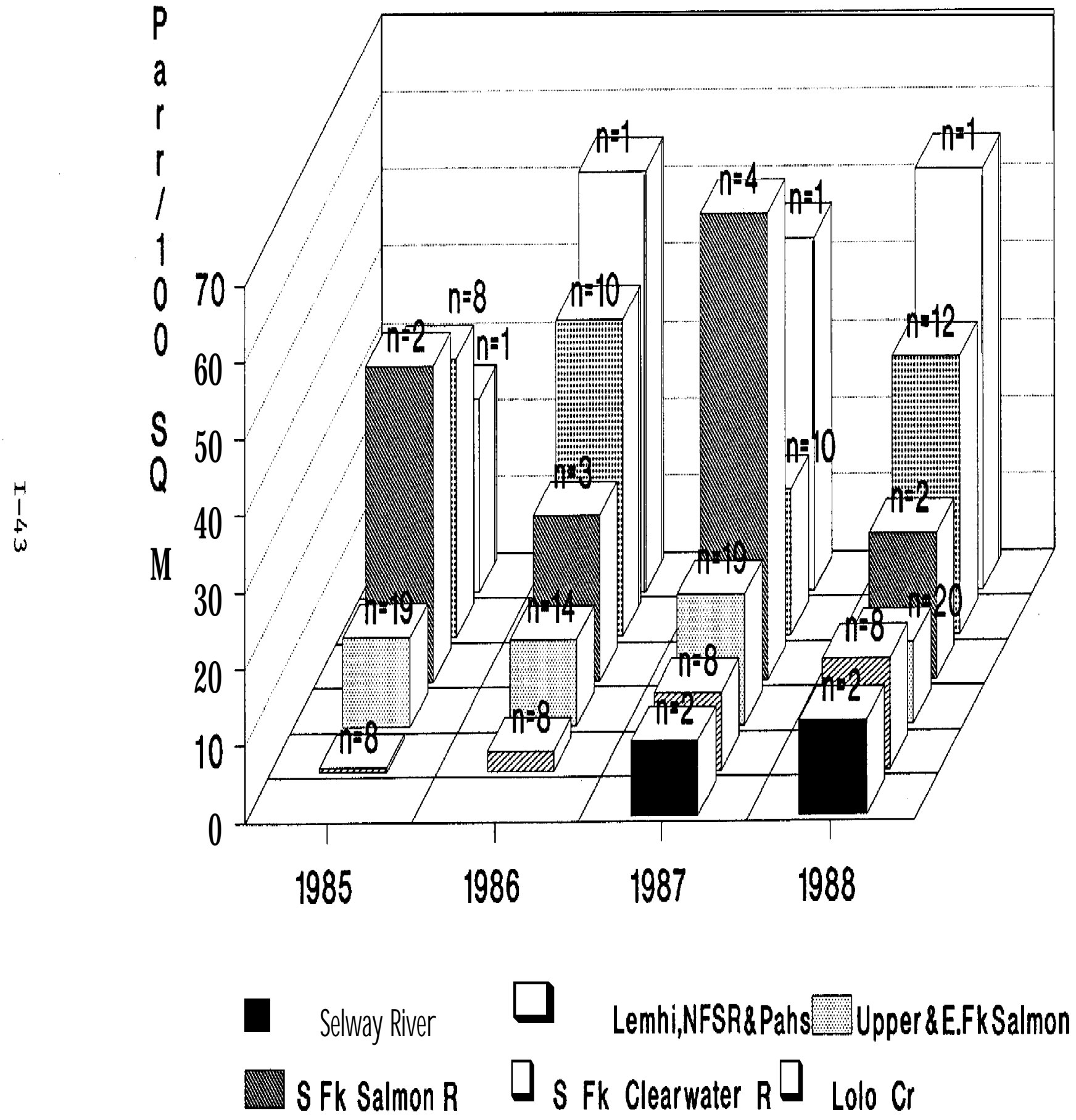

Figure 15. Mean annual densities of age-0t chinook parr in four natural chinook production areas, 1984-1988. 
observed because the low escapements precluded significant seeding of these areas.

In summary, where spawning and rearing habitat are in good condition and the indigenous genetic stock is in tact, chinook production was fair $(18-30 \%$ PCC) in localized areas. Chinook parr production was limited by low escapement, due primarily to continued poor main stem flow and passage conditions.

\section{Parr Densities in Main Stem Corridors}

Snorkel counts were made by IDFG regional management personnel in corridor sections on main stems of the Selway River and the Middle and South Forks of the Salmon Rivers during 1985-88. We compared densities in the headwater and tributary monitoring sections with the densities in main stem corridor sections. Although the snorkeling methods differed in these two stream classes, parr densities should be comparable.

Densities in the main stem rivers were much lower than in headwater and tributary sections (Table 18). Chinook densities in main stem corridors ranged from 3-10\% of those in monitoring sections, and steelhead densities in main stem corridors represented $20-107 \%$ of densities in monitoring sections.

Chinook parr densities in the main stem Selway River were generally much lower than in the main stem of the South and Middle Forks of the Salmon River. Steelhead parr densities were generally the lowest in the Selway River also, but the differences were not as great as with chinook. Sample sizes in the Selway were too small to provide precise estimates (Table 19).

Comparing the Middle and South Forks of the Salmon River, the differences in mean densities of both chinook $(p=0.003)$ and steelhead $(p=0.001)$ were highly significant. There were no significant density differences in either drainage for each species between years. The highest mean densities of both chinook and steelhead were in the South Fork Salmon River.

Although some spawning occurs in main stem rivers, the main stems are important primarily as rearing areas for parr that are produced higher in the drainage. At low escapements, we would expect extremely low parr densities because of a lack of density-dependent dispersal from the primary spawning and rearing areas. We would also expect relatively more use of main stems by steelhead than by chinook parr at low escapements because of life history differences between the two species.

\section{Steelhead Rearing Potential}

For the generally underseeded steelhead populations in Idaho, we hypothesized that a subset of the parr densities exhibiting higher densities would provide a conservative estimate of carrying capacity (CC). The steelhead 
Table 17. Mean annual densities of age-0+ chinook parr in individual drainage cells from 1985 through 1988 in C channels.

\begin{tabular}{cccccc}
\hline & & \multicolumn{4}{c}{ Chinook } \\
\cline { 2 - 5 } Cell locations & 1985 & 1986 & 1987 & 1988 \\
\hline
\end{tabular}

Wild Production Areas:

Middle Fork Salmon River

(without Bear Valley Creek)

Salmon R. Canyon utaries

(Without Chamberlain Basin)

$\begin{array}{lrrrr}\text { All wild summer chinook areas } & 0.6 & 2.2 & 27.8 & 5.3 \\ \text { Chamberlain Cr, upper basin } & 43.8 & 68.2 & 24.1 & \text { ND }\end{array}$

$\begin{array}{lrrrr}\text { Bear Valley Cr. and tribs. } & 1.8 & 1.4 & 1.5 & \mathbf{3 . 8}\end{array}$

Natural Production Areas:

Upper \& East Fk. Salmon R.

Pahsimeroi, Lemhi and

$\begin{array}{rrrr}11.7 & 11.3 & 17.1 & 10.7 \\ 0.6 & 2.6 & 10.1 & 14.5\end{array}$

North Fork Salmon rivers

South Fork Salmon River

Little Salmon River and

tribs (Boulder \& Hazard crs.)

Selway River

Lochsa River

S. Fk. Clearwater River

Lolo Creek

$\begin{array}{rrrr}16.2 & 20.8 & 38.3 & 27.8 \\ * & * & * & * \\ 0.6 & 2.2 & 27.8 & 5.3 \\ 43.8 & 68.2 & 24.1 & \text { ND } \\ 1.8 & 1.4 & 1.5 & 3.8\end{array}$

* = No sections with C channels.

ND $=$ No data.

Table 18. Mean chinook and steelhead densities (number/100 $\mathrm{m}^{2}$ )

from 1985 to 1988 in corridor sections of three

main stem rivers and in monitoring sections of the same drainages.

\begin{tabular}{|c|c|c|c|c|c|c|c|c|}
\hline \multirow[b]{2}{*}{ River systems } & \multicolumn{4}{|c|}{ Chinook densities } & \multicolumn{4}{|c|}{ Steelhead densities } \\
\hline & Corr. & $(n)$ & Mon. & $(n)$ & Corr. & $(n)$ & Mon. & $(n)$ \\
\hline S. Fk. Salmon R. & 1.4 & $(26)$ & 14.1 & $(56)$ & 1.7 & (26) & 1.6 & 190 \\
\hline Salmon R. & 0.3 & $(125)$ & 10.8 & (176) & 0.4 & $(125)$ & 2.0 & $(184$ \\
\hline Selway River & 0.1 & (10) & 1.7 & $(48)$ & 0.5 & (IO) & 1.8 & $(48$ \\
\hline
\end{tabular}


Table 19. Mean annual densities of chinook and steelhead parr in main stem corridor snorkeling sites of three major Idaho drainages.

\begin{tabular}{|c|c|c|c|c|}
\hline Drainages & 1985 & 1986 & 1987 & 1988 \\
\hline \multicolumn{5}{|c|}{$\underline{\text { Chinook Parr Densities and (sample sizes) }}$} \\
\hline S. Fk. Salmon R. & ---- & $0.9(9)$ & $2.9(8)$ & $0.6 \quad(9)$ \\
\hline M. Fk. Salmon R. & $<0.1(25)$ & $0.5 \quad(51)$ & $0.5(20)$ & $0.3 \quad(29)$ \\
\hline Selway River & $0.1(2)$ & $<0.1(1)$ & $<0.1(6)$ & $0.5(1)$ \\
\hline \multicolumn{5}{|c|}{ Steelhead Parr Densities and (sample sizes) } \\
\hline S. Fk. Salmon R. & ---- & $1.6(9)$ & $1.7(8)$ & $1.8 \quad(9)$ \\
\hline M. Fk. Salmon R. & $0.4 \quad(25)$ & $0.4 \quad(51)$ & $0.4 \quad(20)$ & $0.6 \quad(29)$ \\
\hline Selway River & $0.2(2)$ & $0.2(1)$ & $0.7 \quad(6)$ & $0.4 \quad(1)$ \\
\hline
\end{tabular}


CC ratings of $6, \mathbf{1 0}, \mathbf{1 4}$, and 20 for ages-1+ and $\mathbf{- 2 +}$ parr for poor, fair, good, and excellent rearing habitat were compared with a subset of monitoring sections where densities exceeded 75\% of the rated CC (Table 20). The average densities from the subset exceeded the rated carrying capacity for each rating by an average of $25 \%$ (Table 21 ). This suggests that steelhead carrying capacity ratings are near the true $\mathrm{CC}$ and are conservative.

\section{Chinook Rearing Potential}

We hypothesized for chinook, as for steelhead, that a subset of higher chinook parr densities would provide a conservative estimate of carrying capacity. Chinook CC ratings of 12, 44, 77, and 108 for poor, fair, good, and excellent habitat were compared with a subset of monitoring sections where densities exceeded 75\% of the rated carrying capacity (Table 22). There were no densities with poor ratings which exceeded the criterion. Densities in fair and good habitats averaged $116 \%$ of the rated capacity. However, the average density for excellent habitat was only 86\% of the rating (Table 21). In order to further evaluate the CC for chinook parr in excellent habitat, we averaged chinook parr density in both monitoring and evaluation sections (where chinook fry were stocked in excess during May) where parr density exceeded 75\% of the rated carrying capacity in excellent habitat. Average density of 57 samples from July and August was 116 parr $/ 100 \mathrm{~m}^{2}$, or $107 \%$ of the rated carrying capacity. As was observed with steelhead, the parr density ratings for chinook appear slightly conservative.

\section{Chinook Reproduction Curves}

The chinook salmon reproduction curves for the upper and Middle Fork Salmon River and tributaries were further developed using redd counts from 1987 and parr densities from 1988 in 20 monitoring sections. This increased the data set to 88 observations, including redd counts from 1983 through 1987 and parr densities from 1984 through 1988. All sections were in unstocked, C channel habitats. To reduce potential leverage of outliers at low escapements, we included only observations where parr density (R) exceeded $1 / 100 \mathrm{~m}^{2}$ and $P / R>1$, where $P=$ redds/ha.

The data set was incomplete, however, since only eight exceeded 5 redds/ha and only two observations, 10 redds/ha. Thus, the critical part of the relationship is missing where parr densities approach carrying capacity. This would not be so important if a linear relationship existed between redd and parr density, but the actual relationship will be a curve, where additional parr/100 $\mathrm{m}^{2}$ decrease for each incremental increase in redds/ha until an asymptote is reached (i.e. the carrying capacity). Such a curve is appropriate when there is a ceiling in parr abundance imposed by available spawning or rearing habitat (Ricker 1975). In the 1960s, redd densities in Marsh Creek, a stream within the present data set, averaged 18.7 redds/ha (Petrosky and Holubetz 1988) and 
Table 20. Monitoring sections where densities (number/100 $\mathrm{m}^{2}$ ) of steelhead parr (ages-1+ and $-2+$ ) exceeded $75 \%$ of rated carrying capacity in $B$ and $C$ channels.

St ream

Na me

* Channel Type B

BIG CANYON C

BIG CANYON C

BIG CANYON C

BIG CANYON $C$

SALMON R, S FK E FK

ELDORADO CR

ELDORADO CR

ELDORADO CR

ELDORADO CR

ELDORADO CR

CROOKED R

CROOKED R

CROOKED R

CROOKED R

CROOKED R

CROOKED R

CROOKED R

CROOKED R

CROOKED R

LOLO CR

LOLO CR

MEADOW CR

MONUMENTAL C

SAL MONR

SALMON R

WHI TEBIRD CR

$B I G C R$

$B I G C R$

BOULDER CR

BOULDER CR

BOULDER CR

CAPTAIN JOHN CR

CAPTAIN JOHN CR

CHAMBERLAI N CR

CHAMBERLAIN CR

CHAMBERLAIN CR

CHAMBERLAIN CR

GRANITE CR

GRANITE CR

GRANITE CR

GRANITE CR

GRANITE CR

GRANITE CR

\begin{tabular}{|c|c|c|c|c|c|c|}
\hline & \multicolumn{5}{|c|}{ Observed } \\
\hline & & & & Steel head & Rated & Percent \\
\hline & & Channel & & Parr & Carrying & Carrying \\
\hline Strata & Section & Type & Year & Density & Capacity & Capacity \\
\hline
\end{tabular}

\begin{tabular}{|c|c|c|c|}
\hline & & 5 & 1988 \\
\hline & & B & 1987 \\
\hline & & B & 1986 \\
\hline & 1 & B & 1985 \\
\hline & 3 & B & 1987 \\
\hline ABOVE & IHG & B & 1986 \\
\hline ABOVE & 1HG & B & 1987 \\
\hline BELOW & $1 \mathrm{~B}$ & B & 1987 \\
\hline BELOW & 15 & B & 1988 \\
\hline BELOW & $1 \mathrm{~B}$ & B & 1986 \\
\hline I & CONTROLI 1 & 5 & 1988 \\
\hline I & SILL.LOG.B & 5 & 1988 \\
\hline II & CONTROL2 & B & 1986 \\
\hline II & TREAT1 1 & B & 1988 \\
\hline II & TREAT 2 & B & 1988 \\
\hline II & TREAT 2 & 5 & 1987 \\
\hline II & TREAT2 & 8 & 1986 \\
\hline III & CANYON3 & B & 1988 \\
\hline III & CANYON4 & B & 1988 \\
\hline DOWNSTREAM & DS 6 & B & 1986 \\
\hline UPSTREAM & RUN7 & 5 & 1987 \\
\hline CANYON & MI LEPOST2 & B & 1987 \\
\hline & MON3 & 5 & 1985 \\
\hline 10 & A & B & 1988 \\
\hline 10 & A & 5 & 1986 \\
\hline & 1 & B & 1986 \\
\hline LOWER & L1 & B & 1986 \\
\hline LOWE R & L1 & 5 & 1987 \\
\hline BELOW & 3 & B & 1988 \\
\hline BELOW & 5 & 5 & 1986 \\
\hline BELOW & 5 & 5 & 1987 \\
\hline & & 5 & 1986 \\
\hline & 2 & 5 & 1986 \\
\hline & L1 & B & 1987 \\
\hline & L1 & B & 1986 \\
\hline & L2 & B & 1987 \\
\hline & 12 & B & 1986 \\
\hline & 1 & B & 1985 \\
\hline & & B & 1988 \\
\hline & 2 & B & 1988 \\
\hline & 2 & B & 1985 \\
\hline & 3 & B & 1986 \\
\hline & 3 & B & 1988 \\
\hline
\end{tabular}

$\begin{array}{rrr}4.85 & 6 & 80.83 \\ 9.70 & 6 & 161.67 \\ 8.48 & 6 & 141.33 \\ 16.97 & 6 & 282.83 \\ 9.17 & 10 & 91.70 \\ 11.08 & 10 & 110.80 \\ 7.88 & 10 & 78.80 \\ 7.55 & 10 & 75.50 \\ 12.59 & 10 & 125.90 \\ 8.65 & 10 & 86.50 \\ 11.16 & 14 & 79.71 \\ 13.06 & 14 & 93.29 \\ 13.96 & 14 & 99.71 \\ 14.49 & 14 & 103.50 \\ 15.54 & 14 & 111.00 \\ 19.50 & 14 & 139.29 \\ 13.66 & 14 & 97.57 \\ 14.34 & 14 & 102.43 \\ 14.90 & 14 & 106.43 \\ 16.47 & 14 & 117.64 \\ 11.29 & 14 & 80.64 \\ 11.62 & 14 & 83.00 \\ 13.40 & 14 & 95.71 \\ 12.63 & 14 & 90.21 \\ 15.67 & 14 & 111.93 \\ 23.79 & 14 & 169.93 \\ 16.22 & 20 & 81.10 \\ 16.07 & 20 & 80.35 \\ 17.73 & 20 & 88.65 \\ 23.80 & 20 & 119.00 \\ 20.21 & 20 & 101.05 \\ 23.37 & 20 & 116.85 \\ 29.44 & 20 & 147.20 \\ 30.28 & 20 & 151.40 \\ 17.61 & 20 & 88.05 \\ 33.70 & 20 & 168.50 \\ 16.85 & 20 & 84.25 \\ 19.37 & 96.85 \\ 24.78 & 123.90 \\ 15.76 & 18.80 .00 \\ 22.41 & 20 \\ 24.00 & & \\ 36.00 & & \end{array}$




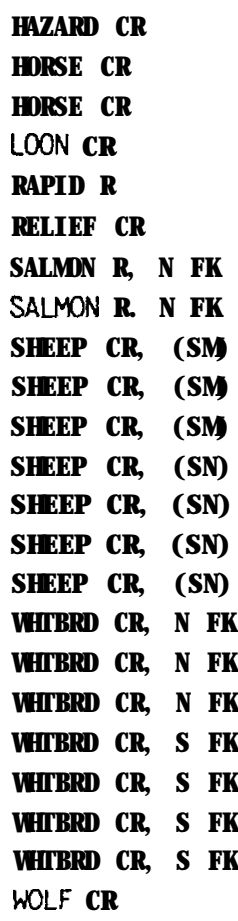

HAZ1
LI
L2
L1
RAP2
RELI EF.CR2
DAHLONEGA
DAHLONEGA
L2
L2
L2


2
2
2
3
3
3
4
1

2
$v$
$v$
$v$

B

CONTROL 2

CONTROL 2

TREAT 2

2

CHA2

GRAZED

BRA

3

9

LEM 1

LEMI

ABOVE

LEM2

LEM2

LEM2

ABOVE

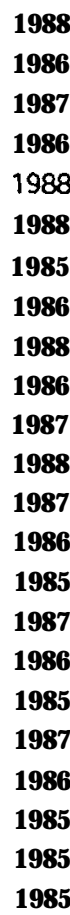

19. 44

20.62

18.98

17.58

21.84

15.87

24,33

15,22

16.00

27.17

29.35

22.13

30.33

31.97

21.31

16.26

29.08

19.46

26.01

31,44

27.46

19.01

17.54

10.40

19.05

7.93

11. 39

10.72

16.67

14.51

15. 92

14.95

14.21

11.11

39.43

19.52

15. 12

20.00

16.74

16.70

15.54

17. 24

61.60

32.80

80.00

26.69

1988
97.20

103. 10

94.90

87.90

109.20

79.35

121.65

76. 10

80.00

135.85

146.75

110.65

151.65

159.85

106.55

81,30

145.40

97.30

130.05

157.20

137.30

95.05

87.J0

104.00

190.50

79.30

113.90

76.57

119.07

103.64

113.71

106.79

101.50

79.36

197.15

97.60

75.60

100.00

83.70

83.50

77. 70

86.20

308.00

164.00

400,00

LOWER $\quad C \quad 1987$

133,45 
Table 21. Mean density and percent of carrying capacity

(PCC) for steelhead and chinook parr in

samples where density exceeded $75 \%$ of rated carrying capacity (CC).

\begin{tabular}{lllll}
\hline Species & CC & Density & PCC & $n$ \\
\hline
\end{tabular}

Steelhead

$\begin{array}{rrrr}6 & 10.0 & 167 & 4 \\ 10 & 10.6 & 106 & 10 \\ 14 & 14.5 & 104 & 23 \\ 20 & 24.4 & 122 & 52\end{array}$

Chinook

\begin{tabular}{rcrr}
12 & -- & -- & 0 \\
44 & 57.4 & 131 & 9 \\
77 & 77.8 & 101 & 17 \\
108 & 93.4 & 86 & 5 \\
\hline
\end{tabular}


Table 22. Monitoring sections where densities (number/100 $\mathrm{m}^{2}$ ) of chinook parr (age-0+) exceeded 75\% of rated carrying capacity in $B$ and C channels.

St ream
Name

** Channel Type B

BOULDER CR

CHAMBERLAIN CR

RED R

RED R

CROOKED R

CROOKED R

RED R

CROOKED R

* Channel Type $C$ LOON CR

SALMON R, S FK MONUMENTAL CR, W FK

SALMON R, S FK

SALMON R, S FK

SALMON R

CROOKED R

RED R

RED R

CROOKED R

CROOKED R

CROOKED R

LOLO CR

RED R

SALMON R

LOLO CR

AMERI CAN R

LOLO CR

CAPE HORN CR

SALMON R

ALTURAS LK CR

MARSH CR

SALMONR

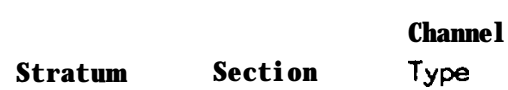

$\begin{array}{lll}\text { BELOW } & \text { 5 } & \text { B } \\ & \text { CHA1 } & \text { B } \\ \text { II } & \text { TREAT2 } & \text { B } \\ \text { II } & \text { CONTROL2 } & \text { B } \\ \text { I } & \text { SILL.LOG.B } & \text { B } \\ \text { I } & \text { BOULDER.B } & \text { B } \\ \text { II } & \text { TREAT2 } & \text { B } \\ \text { II } & \text { CONTROL2 } & \text { B }\end{array}$

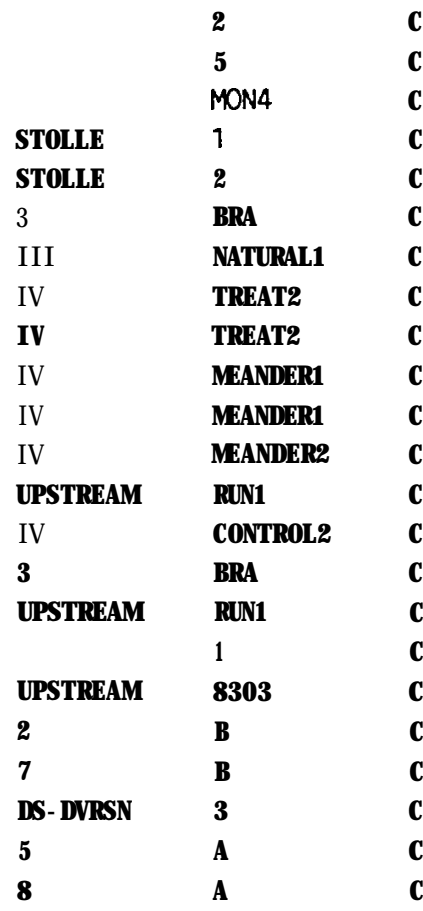

$\begin{array}{rr}\text { Chinook } & \text { Rated Percent } \\ \text { Parr } & \text { Carrying Carrying } \\ \text { Density } & \text { Capacity Capacity }\end{array}$

40.89
34.34
75.42
39.00
57.21
78.94
48.13
90.18

$44 \quad 92.93$

1987

1986

1985

1985

1988

1988

1987

1985

1986

1987

1987

1985

1987

1987

1986

1985

1988

1985

1986

1986

1986

1985

1986

1988

1988

1987

1987

1984

1984

1987

1984

$\begin{array}{rrr}44.82 & 44 & 101.86 \\ 97.22 & 44 & 220.95 \\ 121.22 & 77 & 157.43 \\ 74.96 & 77 & 97.35 \\ 91.46 & 77 & 118.78 \\ 88.76 & 17 & 115.27 \\ 59.67 & 17 & 71.49 \\ 57.94 & 17 & 75.25 \\ 63.49 & 77 & 82.45 \\ 91.87 & 17 & 119.31 \\ 93.42 & 77 & 121.32 \\ 66.80 & 77 & 86.75 \\ 70.71 & 77 & 91.83 \\ 77.78 & 17 & 101.01 \\ 70.65 & 17 & 91.75 \\ 69.70 & 17 & 90.52 \\ 74.83 & 77 & 97.18 \\ 58.31 & 77 & 75.73 \\ 96.81 & 108 & 89.64 \\ 97.76 & 108 & 90.52 \\ 81.92 & 108 & 75.85 \\ 89.32 & 108 & 82.70 \\ 100.96 & 108 & 93.40\end{array}$


the maximum redd density recorded in the $1960 \mathrm{~s}$ was $36.6 /$ ha there were no corresponding parr density data from those years.

Unfortunately,

Acknowledging these data limitations, we present the following models, not as representations of the actual reproduction curves for the Upper and Middle Fork Salmon River chinook stock, but to describe the analyses which will lead to such a representation and to show what information we have and what is still needed.

The chinook redd and parr data were separated into three data sets based on substrate surface sand in the areas where parr densities were collected. The sand class intervals were $0-30 \%, 30-40 \%$ and $>40 \%$. Since sand has a negative effect on emergence of chinook fry, the number of redds/ha should be higher to achieve parr carrying capacity in sedimented streams. Two types of regression analyses were done using redds/ha (P) as an independent variable. One was linear with chinook parr (R) as the dependent recruitment variable, and the other uses the ratio $\mathrm{P} / \mathrm{R}$ as the dependent variable. The former is linear, i.e. it assumes the spawning areas have "infinite productivity," while the latter is a hyperbolic (Beverton-Holt) function which recognizes there is an upper limit, or carrying capacity. Table 23 presents the regression coefficients for both linear and hyperbolic models and their associated coefficients of determinations. Sample sizes were small for the two highest percent sand classes. Therefore, the hyperbolic relation, where percent sand exceeded $40 \%$, should be considered cautiously despite being significant $(p=0.016)$.

Although the regressions were significant for both the linear and hyperbolic models with less than 30\% surface sand, the coefficient of determination for the linear model is much higher (0.46 verses 0.19), indicating that the 1985-1988 redd densities were not approaching parr carrying capacity. Until higher densities of redds occur, the reproduction curve for redds and parr densities cannot be determined.

The linear and hyperbolic curves where sediment was low is shown in Figure 16. The carrying capacity for parr in excellent rearing habitat $\left(108 / 100 \mathrm{~m}^{2}\right.$, based on fry planting studies) is superimposed on the relationship to show where we believe the hyperbolic asymptote will occur when sufficiently high redd density data are available.

An extrapolation of the hyperbolic curve for the low sediment class would predict a carrying capacity of 87 parr $/ 100 \mathrm{~m}^{2}$ when 60 redds/ha occurred. Although data are not presently available to directly estimate the carrying capacity, the estimate of $108 / 100 \mathrm{~m}^{2}$ from fry stocking in Lochsa River tributaries and the historical high densities of 35 redds/ha may approximate carrying capacity. Both are at least five times greater than present densities.

It is encouraging that the regressions show strong differences in predicted parr densities for the different percent sand intervals. This corresponds to the observation that increased sand results in lower parr densities. For example, at 60 redds $/ 100 \mathrm{~m}^{2}$ the hyperbolic equations predict densities of 87,42 , and 5 for the low, moderate, and high sediment classes, respectively. Although the linear equations show the same inverse relationships, they predict 
Table 23. Regression coefficients, significance levels (prob.) and coefficients of determinations $\left(r^{2}\right)$ for linear and Beverton-Holt hyperbolic reproduction curves for parr density samples where percent surface substrate sand was $\leq 30 \%, 30-40 \%$ and $140 \%$. The relations are between the parental redds/ha (P) and the recruited parr/100 Jf (R).

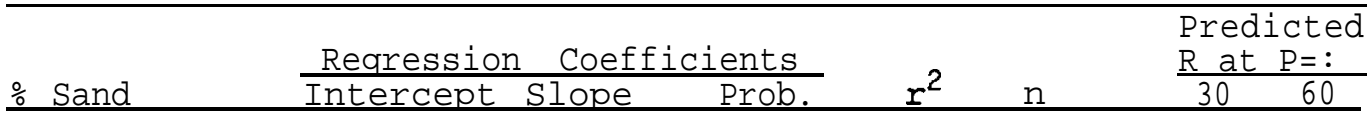

Linear:

$\begin{array}{rrrrrrrrr}0 \text { to } 30 \% & 9.05 & 4.99 & 0.000 * & 0.46 & 49 & 158 & 308 \\ 30 \text { to } 40 \% & 12.96 & 1.41 & 0.442 & 0.09 & 9 & 55 & 98 \\ >40 \% & 8.08 & -1.44 & 0.370 & 0.08 & 12 & -35 & -78\end{array}$

Bev.-Holt:

$\begin{array}{rrrrrrrr}0 \text { to } 30 \% & 0.09 & 0.01 & 0,002 " & 0.19 & 49 & 77 & 87 \\ 30 \text { T0 } 40 \% & 0.23 & 0.02 & 0.365 & 0.12 & 9 & 36 & 42 \\ >40 \% & 0.20 & 0.18 & 0.016 " & 0.46 & 12 & 5 & 5\end{array}$

$\star=$ significant at $\mathrm{p}=0.05$. 


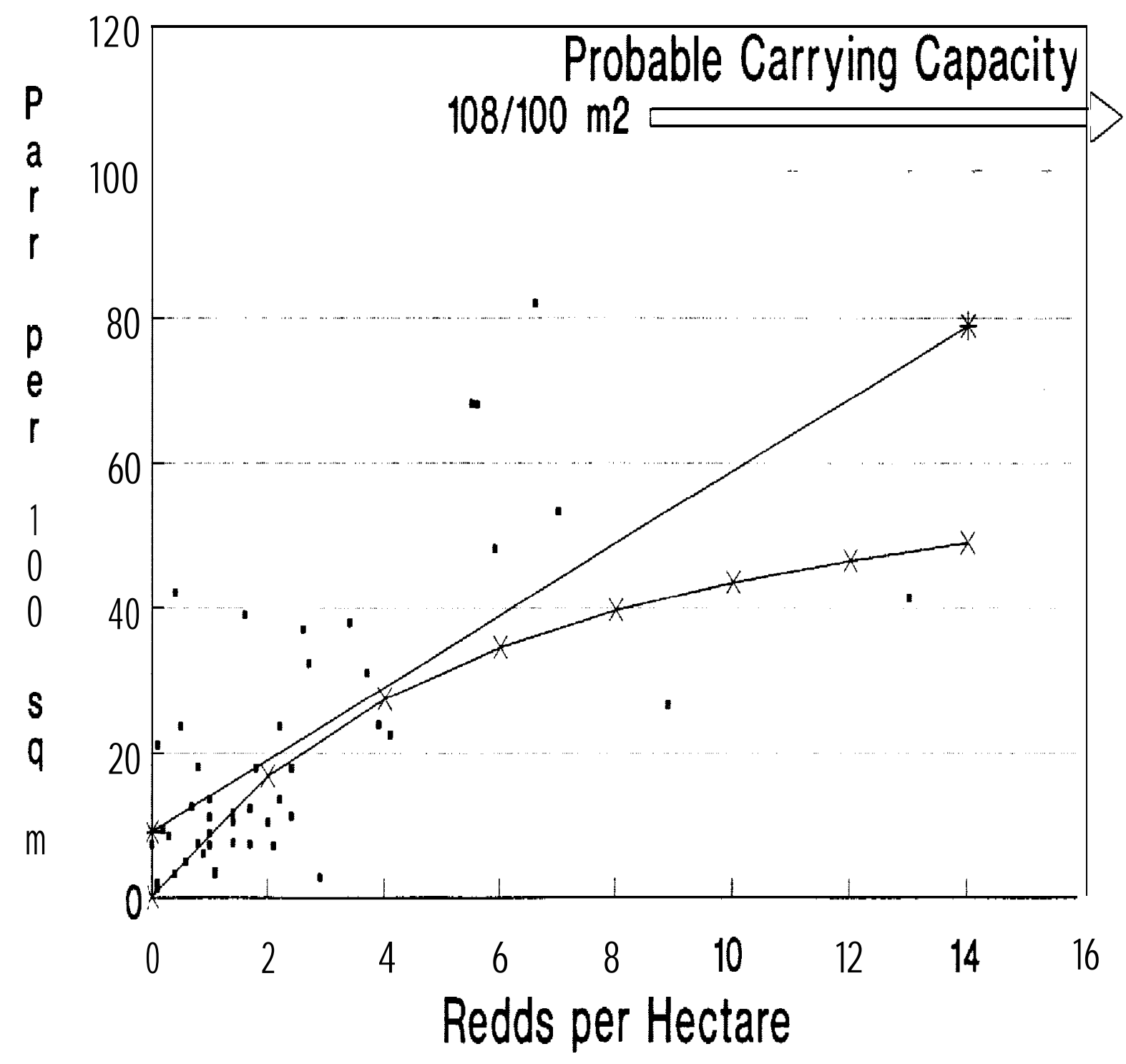

\section{* Bever ton_Holt Curve * Linear Regression}

Figure 16. Linear and Beverton-Holt regression lines for the density of chinook parr expected as redds per hectare increase. The large arrow represents our best estimate of parr carrying capacity. Scatter points represent redds/ha:parr/100 in data from the upper and Middle Fork Salmon River for brood years 1983-1987, for streams with $<30 \%$ substrate surface sand. 
unattainable high densities in the low sediment class and nonsensical negative densities in the high sediment class.

\section{Chinook Egq-to-Parr Survival}

Chinook fry have been stocked in upper Lochsa River tributaries (White Sand and Crooked Fork Creek drainages), Eldorado, Boulder, and Johnson Creeks from 1986 to 1988 to initiate populations above barrier removal projects and/or to estimate chinook parr carrying capacities.

The mean unweighted survival rate from mid-May to mid-August for the 13 fry plant evaluations was 19.8\% (Table 24). Survival ranged from 11.1 to 32.9\%. The streams stocked included both basalt and granitic geologies, as well as wilderness and multiple use drainages. Green egg-to-fry survival in Idaho hatcheries averages approximately 75\% (Steve Huffaker, IDFG, personal communication). Therefore, the actual mean survival of the supplemented fry from green egg to parr was $19.8 \times 75 \%$ or $14.9 \%$.

Chinook fry stocking in the upper Lochsa River in 1988 probably did not fully seed stream reaches in the vicinity of the stocking sites. Chinook parr densities were summarized by location and habitat to estimate summer rearing potential and fry-to-parr survival. Thirteen to I5 weeks after stocking (mid August 1988), the fry had dispersed substantially, primarily downstream from the stocking sites (Table 25). Densities within $2 \mathrm{~km}$ downstream of the stocking sites averaged $60.6 / 100 \mathrm{~m}^{2}$, (range from 38 to $112.2 / 100 \mathrm{~m}^{2}$, $60 \% \mathrm{~B}$ channel); $42.3 / 100 \mathrm{~m}^{2}$ in Hopeful Creek (range from 26.9 to $55.3 / 100 \mathrm{~m}^{2}, 80 \% \mathrm{~B}$ channel); $83.7 / 100 \mathrm{~m}^{2}$ in Big Flat Creek (range from 67.9 to $96.9 / 100 \mathrm{~m}^{2}, 100 \% \mathrm{C}$ channel); and $75.1 / 100 \mathrm{~m}^{2}$ in White Sand Creek (range from 62.7 to $100.0 / 100 \mathrm{~m}^{2}, 100 \% \mathrm{C}$ channel).

Fewer fry were available for stocking in 1988 than in 1987. This resulted in lower mean densities in the study area. There were 18,200 fewer fry stocked in upper Crooked Fork Creek, 25,800 fewer in Big Flat Creek, and 44,150 fewer in White Sand Creek in 1988.

The systematic stratified sampling design produced precise but conservative estimates of chinook parr abundance and survival (Table 26). Bounds on the error of estimation $(+2 \mathrm{SE})$ averaged $9.5 \%$ of the estimated totals for all four sites. The error of estimation was considerably higher in the B channel streams (13.6\% in Crooked Fork and Hopeful Creeks) than in the C channel streams (5.4\% in Big Flat and White Sand Creeks). Estimated chinook fry-to-parr survival (May to August) averaged 23.3\% for the four sites. Survival was lower in the B channel streams (18.0\%) compared to the C channel streams (28.7\%). Survival estimates were conservative because some parr probably dispersed outside the study area.

Chinook eyed eggs were stocked in "artificial" redds (White 1980) in four Idaho streams in the fall of 1987. Survival of eggs to mid summer parr averaged $0.7 \%$ and ranged from $0.3 \%$ to $1.2 \%$ (Table 27). Since $85 \%$ of green eggs generally survive to the eyed-egg stage in Idaho hatcheries (Steve Huffaker, IDFG, personal 
Table 24. Mid-August parr survival from mid-May fry releases of chinook salmon into seven Idaho streams from 1986 to 1988.

\begin{tabular}{|c|c|c|c|c|c|}
\hline Stream & Year & $\begin{array}{l}\text { \# stocked } \\
(\text { mid-May) }\end{array}$ & $\begin{array}{l}\# \quad \text { survive } \\
\text { mid-Augh } \\
( \pm 2 S E \text { as }\end{array}$ & $\begin{array}{l}d \text { to } \\
\text { ust } \\
\text { a \%) }\end{array}$ & $\stackrel{\frac{0}{0}}{\text { survival }}$ \\
\hline White Sand Cr. & $\begin{array}{l}1987 \\
1988\end{array}$ & $\begin{array}{l}152,200 \\
108,300\end{array}$ & $\begin{array}{l}45,064 \pm \\
26,470 \pm\end{array}$ & $\begin{array}{r}23.0 \% \\
5.9 \%\end{array}$ & $\begin{array}{l}29.6 \\
24.4\end{array}$ \\
\hline Big Flat $\mathrm{Cr}$. & $\begin{array}{l}1987 \\
1988\end{array}$ & $\begin{array}{l}97,800 \\
72,200\end{array}$ & $\begin{array}{l}22,106 \pm t \\
23,753 \pm\end{array}$ & $\begin{array}{r}13.0 \% \\
4.8 \%\end{array}$ & $\begin{array}{l}22.6 \\
32.9\end{array}$ \\
\hline Crooked Fork Cr. & $\begin{array}{l}1986 \\
1987 \\
1988\end{array}$ & $\begin{array}{r}101,100 \\
164,300 \\
40,600\end{array}$ & $\begin{array}{r}11,457 \\
32,568 \pm \\
8,860 \pm\end{array}$ & $\begin{array}{l}53.0 \% \\
25.0 \% \\
16.8 \%\end{array}$ & $\begin{array}{l}11.3 \\
19.8 \\
21.8\end{array}$ \\
\hline Hopeful $\mathrm{Cr}$. & $\begin{array}{l}1986 \\
1988\end{array}$ & $\begin{array}{l}55,100 \\
62,200\end{array}$ & $\begin{array}{l}6,131 \pm \\
8,796 \pm\end{array}$ & $\begin{array}{r}136.0 \% \\
9.0 \%\end{array}$ & $\begin{array}{l}11.1 \\
14.1\end{array}$ \\
\hline Eldorado $\mathrm{Cr}$. & 1986 & 199,000 & $30,203 \pm$ & $44.0 \%$ & 15.2 \\
\hline Boulder Cr. & 1986 & 99,900 & $28,112 \pm$ & $88.0 \%$ & 28.1 \\
\hline Johnson $\mathrm{Cr}$. & $\begin{array}{l}1986 \\
1987\end{array}$ & $\begin{array}{r}186,000 \\
34,500\end{array}$ & $\begin{array}{r}23,711 \pm \\
3,102 \pm\end{array}$ & $\begin{array}{l}43.0 \% \\
92.0 \%\end{array}$ & $\begin{array}{l}12.8 \\
13.3\end{array}$ \\
\hline \multicolumn{5}{|c|}{$\begin{array}{l}\text { unweighted mean } \% \text { survival: } \\
\text { Ir survival }(=75 \% \text { of } 19.8) \text { : }\end{array}$} & $\begin{array}{l}19.8 \\
14.9\end{array}$ \\
\hline
\end{tabular}


Table 25. Summary of chinook parr density (number $/ 100 \mathrm{~m}^{2}$ ) 13 to 15 weeks after stocking near four sites, Upper Lochsa River, August 1988.

\begin{tabular}{lllll}
\hline $\begin{array}{l}\text { Stream, } \\
\text { stocking }\end{array}$ & 1988 \\
site & Date & Stratum Section Density type gradient width(m) run & Channel Percent & Mean Pond \\
\hline
\end{tabular}

Crooked Fork Creek

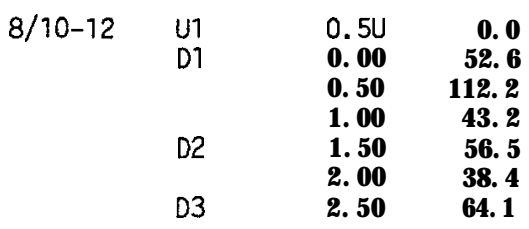

$\begin{array}{ll}\text { B } & 3.7 \\ \text { C } & 0.2 \\ \text { B } & 0.9 \\ \text { C } & 2.3 \\ \text { B } & 1.2 \\ \text { B } & 2.4 \\ \text { B } & \end{array}$

$\begin{array}{llr}3.1 & 40 & 26 \\ 3.4 & 78 & 27 \\ 3.2 & 47 & 19 \\ 3.0 & 58 & 5 \\ 3.5 & 67 & 3 \\ 4.1 & 0 & 5 \\ 4.5 & & \end{array}$

Hopeful Creek

2.

$\begin{array}{cccc}8 / 10-11 & \text { U1 } & 1.00 & 0.9 \\ & & 0.5 U & 0.0 \\ & \text { D1 } & 0.00 & 26.9 \\ & 0.50 & 42.3 \\ & 1.00 & 50.0 \\ & \text { D2 } & 1.50 & 37.2 \\ & \text { D3 } & 2.00 & 55.3 \\ & 2.50 & 28.6\end{array}$

$\begin{array}{lll}\text { U1 } & 1.5 U & 53.3 \\ & 1.0 U & 28.0 \\ & 0.5 U & 56.6 \\ \text { D1 } & 0.00 & 86.0 \\ & 0.50 & 67.9 \\ & 1.00 & 74.7 \\ \text { D2 } & 1.50 & 92.8 \\ & 2.00 & 96.9 \\ \text { D3 } & 2.50 & 54.2 \\ & 3.00 & 11.8\end{array}$

$\begin{array}{ll}C & 0.5 \\ C & 0.1 \\ C & 0.1 \\ C & 1.1 \\ C & 0.1 \\ C & 0.1 \\ C & \\ C & 0.1 \\ C & 0.3 \\ C & 0.1\end{array}$

3.6
1.9
1.2
1.8
1.4
2.8
1.9

$\begin{array}{ll}3.2 & 25 \\ 5.8 & 93 \\ 6.0 & 93 \\ 5.1 & 58 \\ 6.5 & 58 \\ 6.1 & 58 \\ 7.6 & 42\end{array}$

4
7
4
6
2
0
12

Big Flat Creek

3.
$8 / 14$

3.00

11.8

White Sand Creek

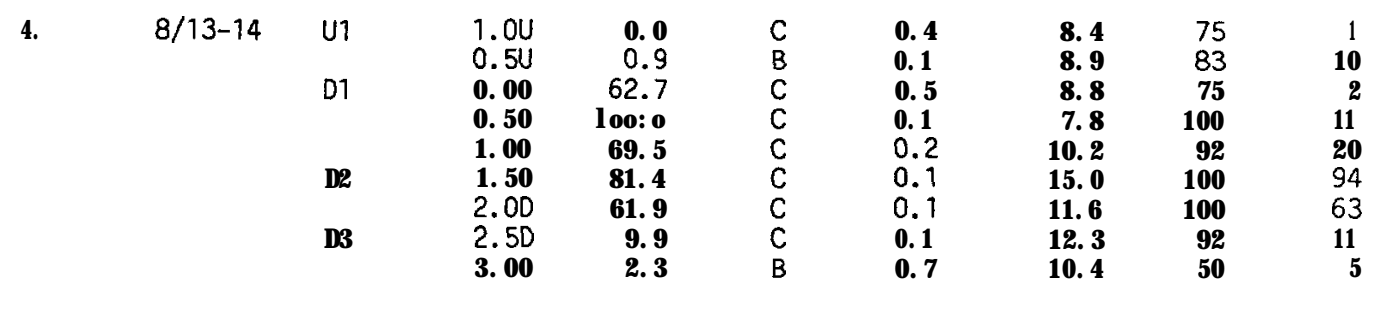


Table 26. Total abundance and fry-to-parr survival estimates

for age-0 chinook, at four stocking sites, upper

Lochsa River, August 1988.

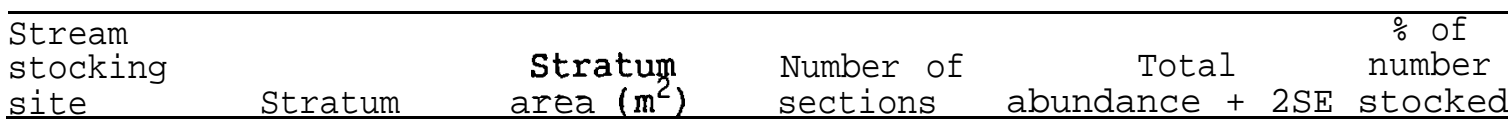

Crooked Fork Creek

1.

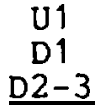

$\mathrm{U} 1$
$\mathrm{D} 1$
$\mathrm{D} 2-3$

Total:

\section{6,400}

7,015

13,415
1
3
3

$\underline{3}$

7 $\begin{array}{r}0 \pm 0 \\ 4,438 \pm 2,767 \\ 3,719 \pm 1,070 \\ \hline\end{array}$

$8,157 \pm 1,367$
10.9

9.2

$21.8 *$

Hopeful Creek

2 .

$$
\begin{aligned}
& \begin{array}{ll}
\text { U1 } & 4,500 \\
\text { D1 } & 8,800
\end{array} \\
& \text { D2 } \\
& 10,250
\end{aligned}
$$

$$
\begin{aligned}
& 2 \\
& 3 \\
& 3
\end{aligned}
$$

8

$$
\begin{gathered}
19 \pm 38 \\
3,495 \pm 1,194 \\
4,135 \pm 1,610 \\
7,649 \pm 792
\end{gathered}
$$$$
<0.1
$$

\begin{tabular}{|c|c|}
\hline $\begin{array}{l}\text { U1 } \\
\text { D1 } \\
\text { D2 } \\
\text { D3 } \\
\end{array}$ & $\begin{array}{l}10,781 \\
17,900 \\
16,375 \\
11,350 \\
\end{array}$ \\
\hline lotal: & \\
\hline
\end{tabular}$$
5.6
$$$$
\underline{6.6}
$$$$
\text { 14. } 1 \text { * }
$$

Big Flat Creek

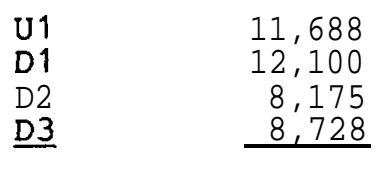

Total:
3.

4.

White Sand Creek

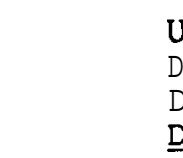

\begin{tabular}{ll}
3 & $3,899 \pm 2,843$ \\
3 & $9,220 \pm 1,278$ \\
2 & $7,751 \pm 337$ \\
2 & $2,883 \pm 3,700$ \\
\hline
\end{tabular}

12.8

10.7

$\underline{4.0}$

10

$23,753 \pm 1,151$
2

3

2

$\underline{2}$

9

0.1

12.8

11.0

0.6

$11,875 \pm 3,235$
$692 \pm 852$

24.4

= Estimate includes chinook in that portion of Crooked Fork Creek below the mouth of Hopeful Creek. Chinook from both creeks dispersed and reared in this area. 
communication), the actual survival estimate from green egg to mid-summer parr was $0.7 \times 85 \%$ or $0.6 \%$.

Egg-to-Parr survival for wild and natural chinook spawning was estimated in the upper Salmon River and the Middle Fork of the Salmon River tributaries (Table 28). Assuming an average fecundity of 5,900 eggs and 1.5 redds per female, mean egg-to-parr survival for all streams combined was 15.2\%, similar to that for fry planting. If the highly sedimented Bear Valley and Elk Creek data were excluded, resulting in a set of streams similar in *quality to those where fry planting evaluations occurred (Table 24), then egg-to-parr survival from wild/natural spawning was superior to that from fry planting (21.1\% versus 14.9\%). If we assumed only one redd per female (a conservative value) then the above comparison would change to $14.1 \%$ verses $14.9 \%$.

\section{Partial Proiect Benefits}

Of the four types of habitat improvement projects evaluated barrier removals, off-channel developments, instream structures, and sediment reduction, the former has had the greatest benefit in terms of numbers of parr produced. From 1986 through 1988, 52\% of steelhead and 72\% of chinook parr produced as project benefits were the result of barrier removals (Tables 29 and 30).

The efficiency of barrier removal projects can be very high when large areas of spawning and rearing habitat are located above the barrier. For example, the Johnson Creek project made $395,000 \mathrm{~m}^{2}$ of rearing area available to chinook. Unfortunately, there are few areas remaining where barrier removals would open up such large areas.

Parr production from all habitat projects are summarized in Tables 29 and 30. During the 1986 through 1988 interval, total parr production attributable to habitat improvement projects averaged 122,874 chinook and 14,618 steelhead. The 1989 annual report will define project benefits in terms of smolt production and expected adult returns, as well as parr production.

Success of some BPA-funded projects will depend on concurrent land management improvements. BPA sediment reduction projects in the Bear Valley/Elk Creek drainage can likely be ineffective unless accompanied by improvements in cattle grazing management and revegetation (Petrosky and Holubetz 1988). With improved land management and sediment reduction, however, we expect large benefits due to increased egg-to-parr survival and carrying capacity from these projects.

\section{Expected Benefits from Flow/Passage and Habitat Improvement}

The ongoing habitat improvement projects in the Salmon and clearwater drainages can not, by themselves, increase depressed anadromous stocks from their present low levels to ones with abundant surpluses. Even Middle Fork 
Table 27. 1988 mid August chinook parr survival estimates from the September 1987 eyed-egg plants and adult releases.

\begin{tabular}{ccc}
\hline & & Eyed-egg to parr \\
Stream & Year & $\frac{0}{0}$ survival +2 SE \\
\hline Boulder $\mathrm{Cr}$. & 1988 & $1.1 \pm 0.7$ \\
Beaver Cr. & 1988 & $0.3 \pm 0.5$ \\
Panther Cr. & 1988 & $1.2 \pm 1.3$ \\
Clear Cr. & 1988 & $0.3 \pm 0.3$ \\
eyed-egg to parr survival: & $\overline{\mathbf{x}}=0.7 \%$ \\
egg-to-eyed egg survival: & $\underline{85 \%}$ \\
green egg-to-parr survival: & $\overline{\mathbf{x}}=0.6 \%$ \\
\hline
\end{tabular}

Table 28. Wild/natural chinook egg to parr survival estimates by $\frac{\circ}{0}$ sand categories. The analysis assumes a fecundity of 5,900 eggs/female and 1.5 redds/female.

\begin{tabular}{|c|c|c|c|c|c|}
\hline $\begin{array}{ll}\% & \text { Surface } \\
& \text { Sand } \\
\end{array}$ & Stream & Year & & $\frac{\circ}{0}$ & Survival \\
\hline \multirow[t]{2}{*}{$<30 \frac{8}{\circ}$} & $\begin{array}{l}\text { Marsh Cr. } \\
\text { Salmon R. }\end{array}$ & $\begin{array}{l}1985 \\
1985\end{array}$ & & & $\begin{array}{r}32.5 \\
25.5 \\
\end{array}$ \\
\hline & & & $\bar{x}$ & $=$ & 29.0 \\
\hline \multirow[t]{2}{*}{$30-40 \%$} & Herd $\mathrm{Cr} .^{\mathrm{a}}$ & $\begin{array}{l}1986 \\
1987\end{array}$ & & & $\begin{array}{l}13.0 \\
13.3 \\
\end{array}$ \\
\hline & & & $\bar{x}$ & $=$ & 13.2 \\
\hline \multirow[t]{2}{*}{$>40 \%$} & $\begin{array}{l}\text { Elk } \mathrm{Cr} . \\
\text { Bear Valley } \mathrm{Cr} .^{a}\end{array}$ & $\begin{array}{l}1985 \\
1986 \\
1987 \\
1984 \\
1985 \\
1986\end{array}$ & & & $\begin{array}{l}6.2 \\
1.7 \\
1.2 \\
8.2 \\
2.2 \\
1.2\end{array}$ \\
\hline & & & $\bar{x}$ & $=$ & 3.4 \\
\hline
\end{tabular}

All habitats (Mean of sand category means): $=15.2 \%$ Mean without Bear Valley and Elk Creeks:. $=21.1 \%$

"Shoshone-Bannock tribe data on parr abundance. 
Table 29. Total abundance of steelhead parr (ages-1+ and $\mathbf{- 2 +}$ ) attributed to benefits of implemented projects, 1985-

1988. (See Appendix B for calculations and assumptions).

\begin{tabular}{|c|c|c|c|c|c|}
\hline $\begin{array}{l}\text { Project type, } \\
\text { stream }\end{array}$ & $\frac{\text { Steel }}{1985}$ & $\frac{\text { lhead pa }}{1986}$ & $\frac{\text { cr benefi }}{1987}$ & $\frac{\text { its }}{1988}$ & $\begin{array}{l}\text { Potential } \\
\text { parr } \\
\text { benefits }\end{array}$ \\
\hline $\begin{array}{l}\text { Barrier Removal } \\
\text { Complete } \\
\text { Eldorado } \mathrm{Cr} . \\
\text { Pine } \mathrm{Cr} . \\
\text { Colt } \mathrm{Cr} .\end{array}$ & (Adult & $\begin{array}{l}7,310 \\
\text { passage }\end{array}$ & $\begin{array}{l}5,266 \\
\text { infeasib }\end{array}$ & $\begin{array}{l}1,306 \\
\text { ble) }\end{array}$ & $\begin{array}{r}14,384 \\
0 \\
8,582\end{array}$ \\
\hline $\begin{array}{l}\frac{\text { Partial }}{\text { Crooked Fk. Cr. }} \\
\text { Crooked R. (culvert } \\
\text { Pole Cr. (screen) } \\
\text { Dollar Cr. } \\
\text { (Sub-total } 1 \text { ) }\end{array}$ & $\begin{array}{l}210 \\
210\end{array}$ & $\begin{array}{r}277 \\
1,375 \\
23 \\
8,985\end{array}$ & $\begin{array}{r}85 \\
1,174 \\
32 \\
1.060 \\
7,617\end{array}$ & $\begin{array}{r}0 \\
1,958 \\
381 \\
2.461 \\
6,106\end{array}$ & $\begin{array}{r}54,521 \\
10,790 \\
1,943 \\
4,785 \\
95,005\end{array}$ \\
\hline $\begin{array}{l}\text { Off-Channel Development } \\
\text { Crooked R. } \\
\text { Red R. } \\
\text { (Sub-total 2) }\end{array}$ & & $\frac{323}{32:}$ & $\begin{array}{l}3.076 \\
\frac{1-\text { no }}{3,076}\end{array}$ & $\begin{array}{r}1.108 \\
\text { data- } \\
1,108\end{array}$ & $\begin{array}{l}912 \\
\frac{28}{940}\end{array}$ \\
\hline $\begin{array}{l}\text { Instream } \mathrm{C}+\text { ractures } \\
\text { Lolo } \mathrm{Cr} \text {. }\end{array}$ & 3,410 & 4,003 & 2,965 & 1,186 & $b$ \\
\hline $\begin{array}{l}\text { Upper Lochsa R. } \\
\text { Red R. } \\
\text { (Sub-total } \\
\text { 3) }\end{array}$ & $\begin{aligned} &-72 \text { (no } \\
& 704 \\
& 4,042\end{aligned}$ & $\begin{array}{c}\text { measinrab] } \\
-235 \\
3,768\end{array}$ & 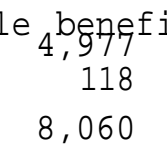 & $\begin{array}{r}\text { its) } \\
-1,813 \\
\frac{-1,058}{2,941}\end{array}$ & $\begin{array}{l}b \\
b\end{array}$ \\
\hline $\begin{array}{l}\text { Sediment Reduction } \\
\text { Bear Valley/Elk Cr. } \\
\text { (Sub-total 4) }\end{array}$ & & & & $\frac{-2,383}{-2,383}$ & $b$ \\
\hline Grand Totals: & 4,252 & 13,077 & 18,753 & 7,772 & \\
\hline
\end{tabular}

'Additionally, in 1984, 1,109 steelhead parr were a benefit of the Lolo Creek instream structure project.

botential parr benefits from instream structures and sediment reduction projects are not measurable since the differences in carrying capacity before and after project maturity is unknown. 
Table 30. Total abundance of chinook parr (age-0+) attributed to benefits of implemented projects, 1985-1988. (See Appendix B for calculations and assumptions).

\begin{tabular}{|c|c|c|c|c|c|}
\hline $\begin{array}{l}\text { Project type, } \\
\text { stream }\end{array}$ & $\frac{\mathrm{Ch}}{1985}$ & $\frac{\text { hinook Parr }}{1986}$ & $\frac{\text { Benefits }}{1987}$ & 1988 & $\begin{array}{l}\text { Potential } \\
\text { parr } \\
\text { benefits } \\
\end{array}$ \\
\hline $\begin{array}{l}\text { Barrier Removal } \\
\text { Complete } \\
\text { Eldorado } \mathrm{Cr} . \\
\text { Crooked } \mathrm{Fk} . \mathrm{Cr} \text {. } \\
\text { Johnson } \mathrm{Cr} . \\
\text { Boulder } \mathrm{Cr} . \\
\text { Meadow } \mathrm{Cr} . \\
\text { Knapp } \mathrm{Cr} .\end{array}$ & 7,206 & $\begin{array}{l}30,206 \\
17,600 \\
23,711 \\
28,112\end{array}$ & $\begin{array}{r}13,328 \\
32,600 \\
17,700 \\
0\end{array}$ & $\begin{array}{r}5,936 \\
17,700 \\
52,086 \\
1,560 \\
15,000 \\
63\end{array}$ & $\begin{array}{r}110,478 \\
57,248 \\
294,750 \\
82,504 \\
39,036 \\
84,040\end{array}$ \\
\hline $\begin{array}{l}\frac{\text { Partial }}{\text { Crooked R. }} \\
\text { (culvert) } \\
\text { Pole Cr. (screen) } \\
\text { Dollar Ct. } \\
\text { (Sub-total } 1 \text { ) }\end{array}$ & $\begin{array}{r}5,351 \\
0 \\
12,557\end{array}$ & $\begin{array}{r}3,707 \\
0 \\
103,336\end{array}$ & $\begin{array}{r}742 \\
0 \\
0 \\
64,370\end{array}$ & $\begin{array}{r}7,061 \\
8 \\
38 \\
99,452\end{array}$ & $\begin{array}{r}18,562 \\
14,962 \\
7,255 \\
708,835\end{array}$ \\
\hline $\begin{array}{l}\text { Off-Channel Developmen } \\
\text { Crooked R. } \\
\text { Red R. } \\
\begin{array}{ll}\text { (Sub-total } & \text { 2) }\end{array}\end{array}$ & $\frac{5,351}{5,351}$ & $\begin{array}{l}3,707 \\
2 \quad 15 \\
3,922\end{array}$ & $\begin{array}{l}742 \\
(- \text { no } \\
742\end{array}$ & $\begin{array}{r}7,061 \\
\text { data- }) \\
7,061\end{array}$ & $\begin{array}{r}37,123 \\
216 \\
37,339\end{array}$ \\
\hline Instrôiom Cr.actures & 7,116 & $-15,715$ & 29,758 & 5,930 & a \\
\hline $\begin{array}{l}\text { Upper Irockhsa R. } \\
\text { Red R. } \\
(\text { Sub-total } \\
\text { 3) }\end{array}$ & $\begin{array}{l}-5,121 \text { ho } \\
9,291 \\
\frac{11,286}{}\end{array}$ & $\begin{array}{l}\text { measurable } \\
\frac{9,526}{-7,075}\end{array}$ & $\begin{array}{l}\text { bepgfits } \\
\frac{19,052}{50,902}\end{array}$ & $\begin{array}{r}6,852 \\
21,874 \\
34,656\end{array}$ & $\begin{array}{l}\mathrm{a} \\
\mathrm{a}\end{array}$ \\
\hline $\begin{array}{l}\text { Sediment Reduction } \\
\text { Bear Valley/Elk Cr } \\
(\text { Sub-total 4) }\end{array}$ & & & & $\frac{17,489}{17,489}$ & $a$ \\
\hline Grand Totals: & 23,843 & 100,595 & 115,481 & 157,521 & \\
\hline
\end{tabular}

${ }^{a}$ Potential parr benefits from instream structures and sediment reduction projects is not measurable since the diference in carrying capacity before and after project maturation is unknown. 
Salmon River tributaries in pristine condition, such as Sulphur Creek, are not functioning at that level. Inadequate flow and passage conditions during smolt migration remains the major factor preventing the rebound of wild/natural anadromous fish in Idaho.

What some habitat projects can do, however, is increase the egg-to-smolt survival in degraded streams to normal levels. This benefit might make the difference between local populations becoming extinct or remaining marginal. This seems a necessary precaution, since there is still no plan in place to achieve the necessary main stem flows. When improved flow and passage conditions are achieved, then egg-to-smolt survival and carrying capacity increases from habitat projects will contribute to productivity and harvest potential of the wild and natural populations.

The following is a discussion of benefits expected from Middle Fork Salmon River habitat enhancement projects on Elk and Knapp Creeks (BPA project 84-24), with and without improved flows and passage conditions. It should be stressed that the Elk Creek habitat enhancements must include reduction/elimination of negative sediment and riparian conditions caused by cattle grazing to have an impact sufficient to achieve the expected survival benefits. According to the Middle Fork and Upper Salmon River Implementation Plan (Andrews and Everson 1988), "grazing allotment management reviews to incorporate improved riparian management strategies in the allotment management plans are underway and will be complete by 1991." When cattle allotments are managed to eliminate detrimental effects to anadromous fish, then the proposed sediment removal, bank stabilization, channel rehabilitation, protective fencing, and riparian revegetation will jointly result in improved egg-to-smolt survival.

As examples of how flow and passage conditions affect habitat enhancement benefits for chinook, analyses were done on the sediment reduction project in the degraded Elk Creek and the barrier removal project in the relatively pristine Knapp Creek. These analyses incorporate expected changes in smolt-to-adult return rates (SAR) which are controlled largely by flow/passage conditions, as well as expected changes in smolt capacity and egg-to-smolt survival due to habitat improvement.

The simulations indicate that the Elk Creek chinook population faces extinction with or without the project if Snake River flows (measured at Lower Granite Dam) during the peak smolt migration period average 75,000 cfs or less (Table 31). The SAR predicted at flows of 75,000 cfs would be only $0.11 \%$, and improvements in egg-to-smolt survival would not overcome the low SAR. If SAR averaged $0.36 \%$ (at the recommended minimum of 85,000 cfs), then the Elk Creek sediment reduction project and grazing management improvements could make the difference between an extinct or a marginally viable population. But the adult escapement would not be sufficient to allow a terminal harvest.

As main stem flow and SAR increase further, spawning escapements could be met and terminal harvests allowed. At an SAR of $0.98 \%$, as predicted in current models when spring flow at Lower Granite Dam averages 100,000 cfs, a spawning escapement of 873 chinook could be met, with or without the sediment reduction project. The benefit of the habitat project, with this SAR, would be an increase 
Table 31. Project benefits in terms of adult spawners and terminal harvest from projects that increase egg-to-smelt survival. Benefits were estimated from subbasin planning, existing monitoring data, and different smolt-to-adult return rates (SAR) for various main stem flow/passage conditions.

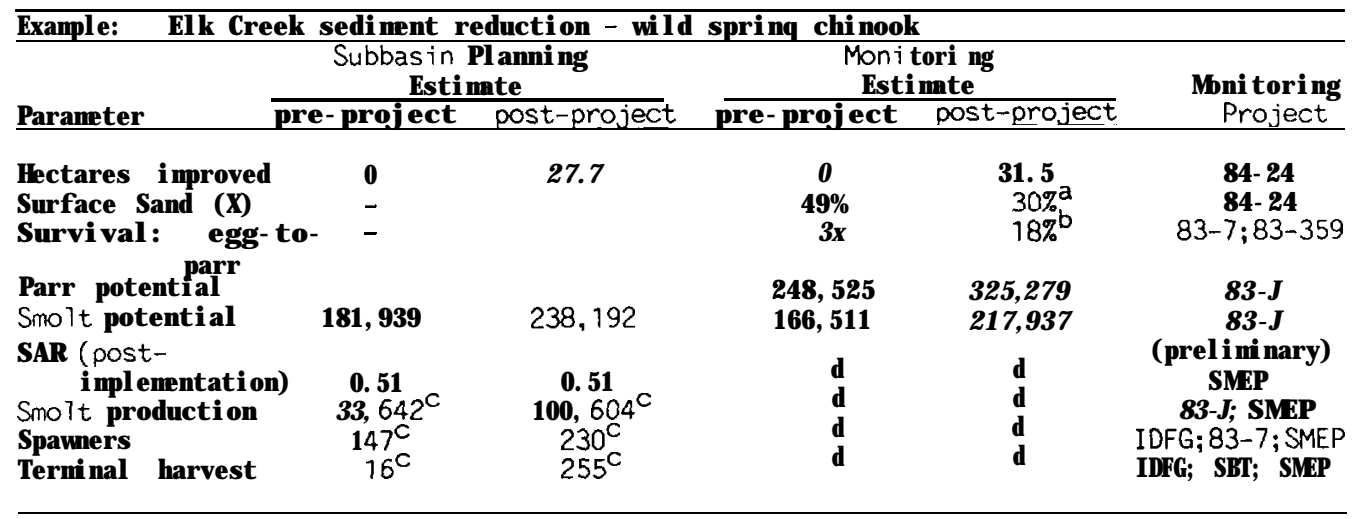

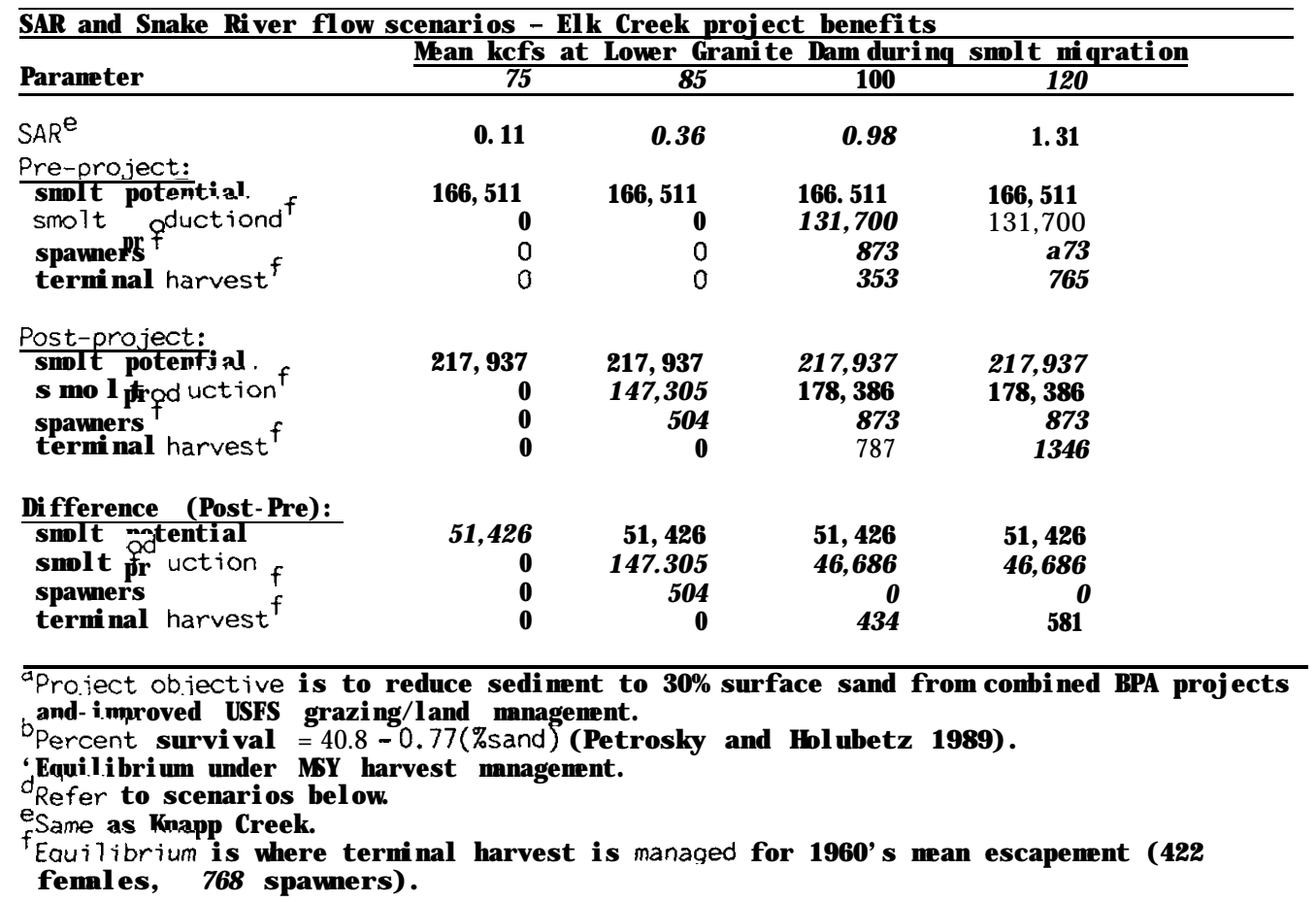


in terminal harvest from 353 to 787. At an SAR of 1.3\%, predicted for a flow of $120,000 \mathrm{cfs}$, the habitat project benefit would be an increase in terminal harvest from 765 to 1,346 .

Of the four smolt migration flow scenarios displayed in Table 31 and above, it is clear that average flow must exceed 75,000 cfs or the Elk Creek chinook population will become extinct with or without the sediment reduction project. At minimum flow $(85,000$ cfs), the project could make the difference between a marginal, unharvestable population and extinction. At some flow exceeding 85,000 cfs the sediment reduction project would begin to make the difference between having, or not having, a harvestable surplus. At higher flows, the habitat project would contribute to the harvestable surplus.

A similar scenario is shown for the Knapp Creek barrier removal project (Table 32). At 75,000 cfs, the entire Middle Fork Salmon River chinook population would face extinction. At 85,000 cfs, projections indicate that a population of 96 spawners could develop above the barrier, too few to allow a terminal harvest. At approximately 100,000 cfs the sustainable adult escapement would stabilize in excess of the optimum 173 spawners, allowing an average annual harvest of 130 chinook. As migration flows exceed 100,000 cfs, benefits would accrue as harvestable surpluses.

\section{Crooked River, Red River, and Lo10 Creek}

With but one exception, there were no significant differences in either chinook or steelhead parr densities between treatment and control sections for Crooked River, Lo10 Creek, or Red River. The exception was for chinook parr in Lo10 Creek. The results are summarized in Table 33. Mean chinook densities were higher in treated reaches, but these differences were generally not significant (Figures 17, 18 and 19). Mean steelhead densities were generally higher in treated than control sections, with the exception of Red River, where steelhead densities were higher in control sections.

\section{DISCUSSION}

The need to use parr density data to document the status of Idaho's anadromous fish stocks is apparent. The number of salmon and steelhead entering the middle Snake River (above Lower Granite Dam) can be counted and the number of hatchery and wild/natural steelhead can be tallied separately (due to the adipose fin-clip on hatchery-produced steelhead smolts) as can the A-run and Brun steelhead. Beyond this classification is much uncertainty. How many spring and summer chinook salmon are hatchery, wild, or natural? How many of the wild/natural steelhead are wild and how many are natural? In the stocks classified as natural, how much has the productivity been altered through supplementation? Are the wild/natural B-run steelhead, which are severely depressed, composed mostly of descendants of supplemented stocks in the intensely supplemented South Fork Clearwater River and East Fork Salmon River? How many 
Table 32. Project benefits in terms of adult spawners and terminal harvest from projects that add habitat or increase carrying capacity. Benefits were esti mated from subbasin planning, existing monitoring data, and different smolt-to-adult return rates (SAR) for various main stem flow/passage conditions.

\begin{tabular}{|c|c|c|c|}
\hline Eample: Knapp Creek barr & $\begin{array}{l}\text { er removal }- \text { wild } \\
\text { Subbasin Planning } \\
\text { Est i mate }\end{array}$ & $\begin{array}{c}\text { spring chinook, } \\
\text { Moni tori ng } \\
\text { Esti mate }\end{array}$ & $\begin{array}{c}\text { Moni tori ng } \\
\text { Project }\end{array}$ \\
\hline $\begin{array}{l}\text { Hectares added } \\
\text { Parr potential } \\
\text { Smolt potential } \\
\text { SAR (post-i mplementation) } \\
\text { Smolt production } \\
\text { Spawners } \\
\text { Terminal harvest }\end{array}$ & $\begin{array}{c}7.6 \\
72,000 \\
0.51 \\
57,998^{a} \\
137 a \\
144^{a}\end{array}$ & $\begin{array}{r}5,9 \\
63,720 \\
42,390 \\
b \\
b \\
b\end{array}$ & $\begin{array}{c}84.24 \\
83.7 \\
83-7 \text { (pre } 1 \text { iminary) } \\
\text { SMEP } \\
83.7 ; \text { SMEP } \\
\text { IDF; 83.7; SMEP } \\
\text { IDFG; SBT; SMEP }\end{array}$ \\
\hline
\end{tabular}

aEquilibrium under MSY harvest management.

befer- to scenarios below.

SAR and Snake River flow scenarios - Knapp Creek project benefits.

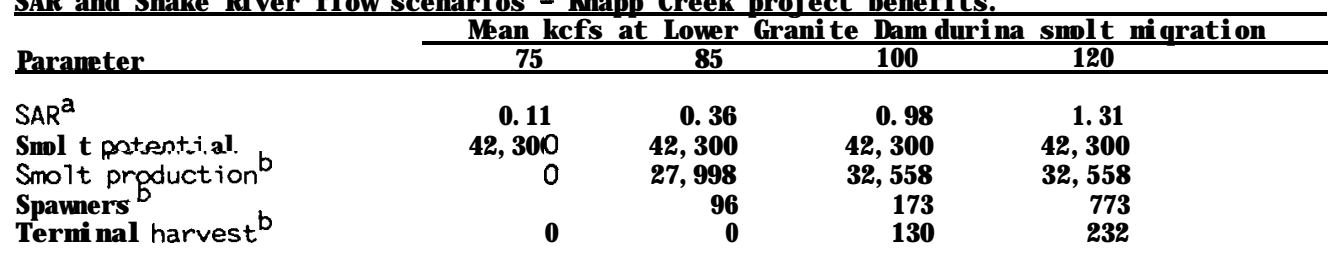

"Empirical relationship for the Middle Fork of the Salmon River wild spring chinook, 1972.1.985. SAR $=1.34 /(1+\operatorname{EXP}(12.49-0.135 *$ KCFS $))$.

bequilibrium where terminal harvest is managed for escapement to approximate the 1960's average for Marsh Creek ( 95 females, 173 adults). 

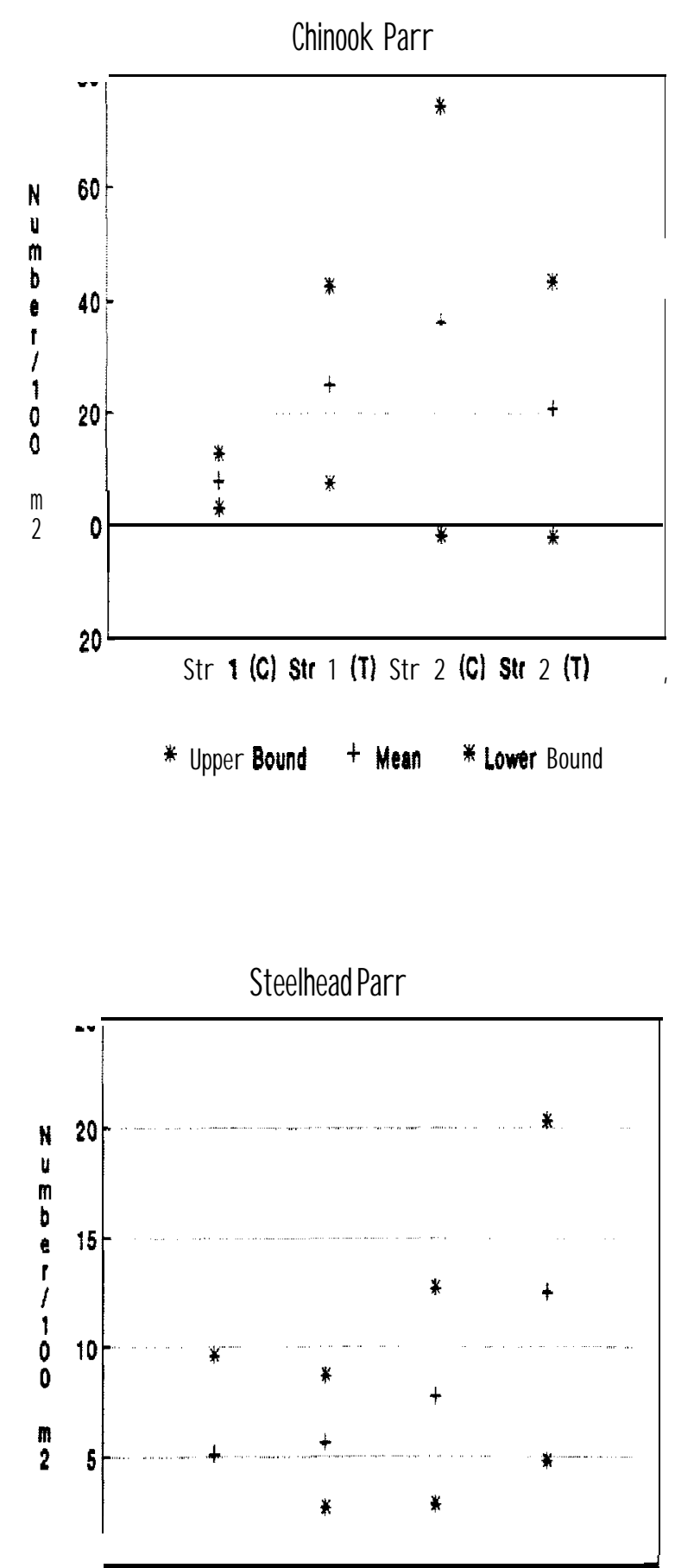

Str $1(C)$ Str 1 (T) Stt 2 (C) Str $2(T)$

* upper Bound + Mean * Lower Bound

Figure 17. Mean densities in control (C) and treatment ( $\mathrm{T}$ ) sections (and $95 \%$ confidence limits) of chinook and steelhead relative to instream structures placed in Crooked River. Values are average for 1985 through 1988. 

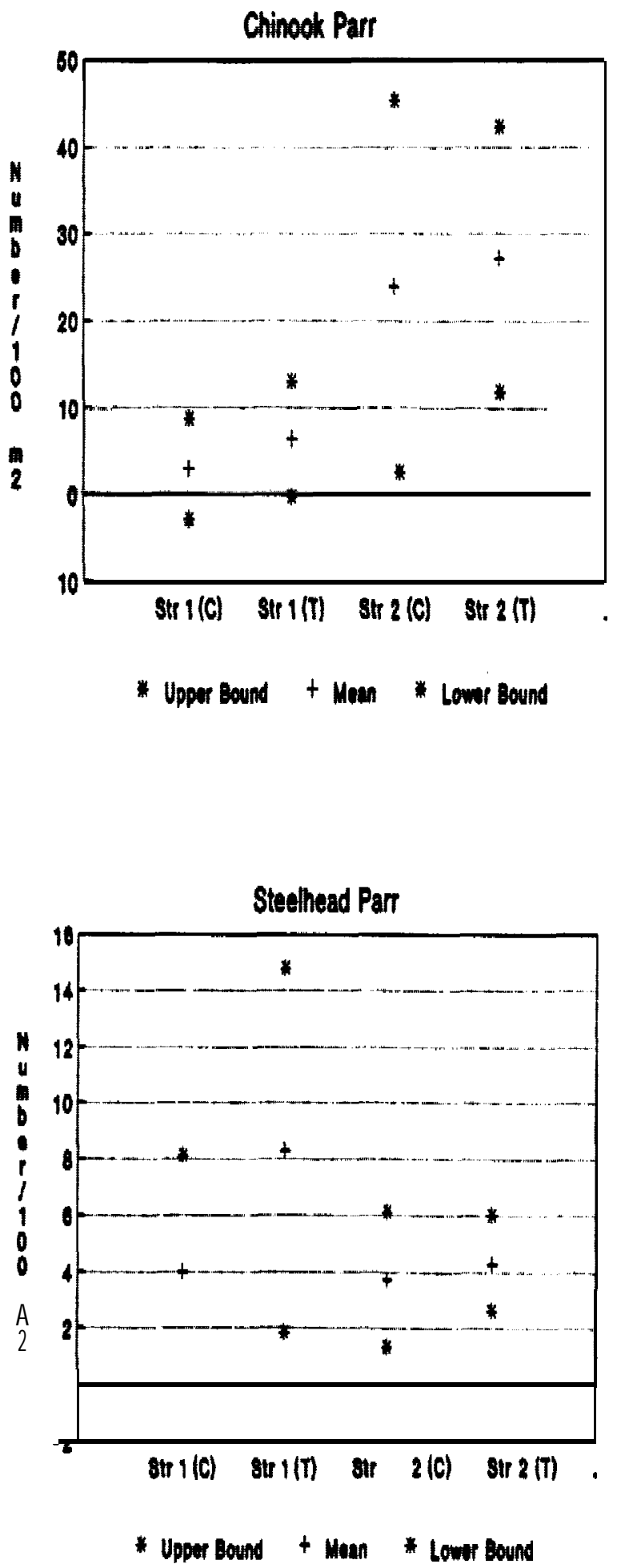

Figure 18. Mean densittes in control (C) and treatment ( $\mathrm{T}$ ) sections (and $95 \%$ confidence limits) of chinook and steelhead relative to instream structures placed in Lolo Creek. Values are averages for 1985 through 1988. 


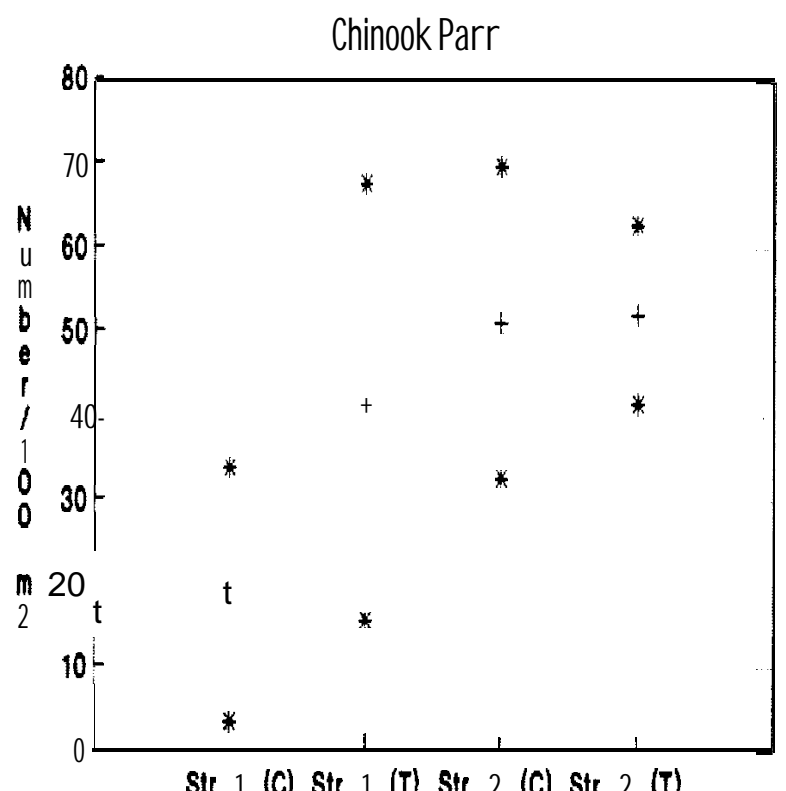

Str 1 (C) Str 1 (T) Str 2 (C) Str 2 (T)

* Upper Bound + Mean * Lower Bound

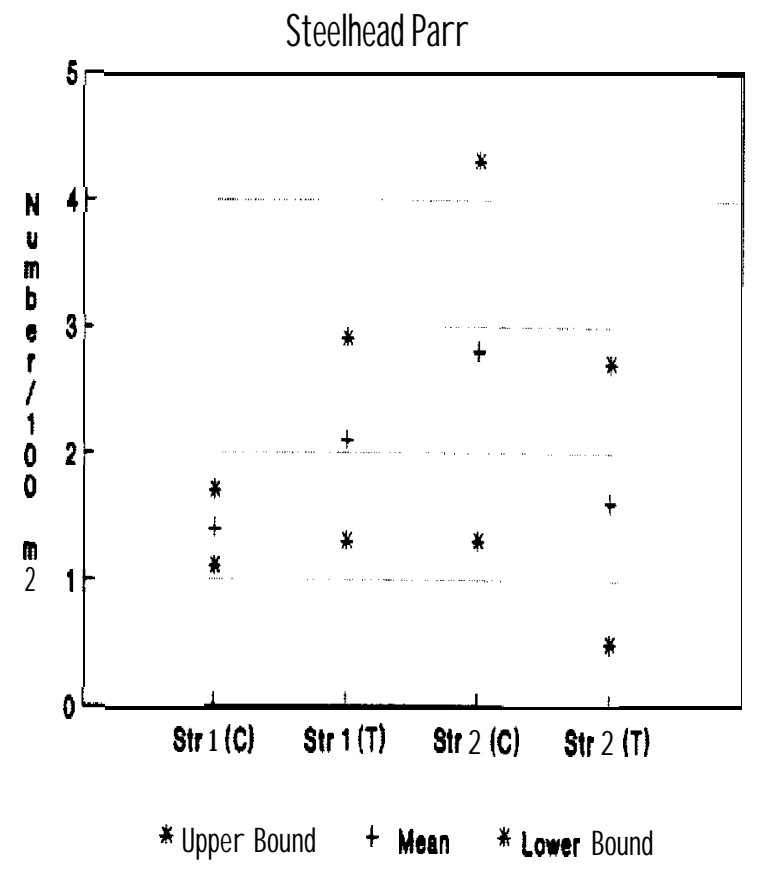

Figure 19. Mean densities in control (C) and treatment ( $\mathrm{T}$ ) sections (and $95 \%$ confidence 1imits) of chinook and steelhead relative to instream structures placed in Red River. Values are averages for 1985 through 1988. 
wild B-run spawners are escaping to the Selway River, to the Middle Fork of the Salmon River, to the South Fork of the Salmon River? If parr densities are an index of spawning escapement, then there must be very few spawners reaching these rivers. How many are not destined for Idaho waters at all, but instead are returning to the Grande Ronde and Imnaha rivers of eastern Washington and Oregon?

The Idaho Department of Fish and Game has surveyed major chinook salmon spawning grounds since before the decline of Idaho chinook populations in the 1970s. Trends in chinook redds are a good indicator of health of these populations. Unfortunately, however, parr densities were not measured when redd densities were high, so the relationship between redds and parr (reproduction curve) is not yet known. We do not know precisely how many redds are needed to achieve full smolt (or parr) capacity. How many redds are needed before a terminal fishery is justified?

Although wild/natural B-run steelhead return to several Idaho rivers, we do not know what fraction of that run is destined for each river. In contrast to chinook redd counts which occur during late summer base flows, steelhead redds must be counted during high, often turbid flows. Strong flows prevent excavated gravel from piling high, and there is little periphyton on surface gravel to aid in redd identification. Steelhead redd counting in Idaho streams has been lacking or inconsistent.

Parr densities, in contrast, can be obtained by snorkeling or electrofishing in any of Idaho's streams during the base flow months of summer.

To validate the use of parr densities as an index of adult escapement, we need to regress parr density on adult escapement of both chinook and steelhead using the Beverton-Holt or alternate models. At existing IDFG weirs, adults are counted as they enter their spawning areas. Sufficient parr density monitoring should be done at random sections above these weirs to provide precise and accurate estimates of parr densities. Some additonal weirs will be needed such that the reproduction curves for each classification of chinook and steelhead can be evaluated. Existing and recommended new weir sites are listed in Table 34 .

Although the relationship between adult escapement and parr density is yet to be quantified, there is corroborating information indicating that wild B-run steelhead stocks are at very low levels as suggested by parr density data. During the adult steelhead run years of 1985 through 1988 (for which there is data from Lower Granite Dam on the number of hatchery and wild/natural steelhead, separately by A-run and B-run), only 23\% of the run has been wild/natural and only 6\% has been wild/natural B-run steelhead (Kent Ball, IDFG, personal communication). This was an average annual run of 6,289 wild/natural B-run steelhead, which went to the three major wild B-run production drainages of the Selway River, South Fork Salmon River, and Middle Fork Salmon River. Additionally, part also returned to the heavily supplemented South Fork Clearwater River, Lolo Creek, East Fork Salmon River, and Lochsa River. Obviously, seeding level was very low for wild/natural B-run steelhead. Of great concern is to know what fraction of the limited wild/natural B-run spawners are actually wild. The genetic integrity of the B-run steelhead stocks may be 
Table 33. Two-way ANova results for the instream structure evaluations on Crooked River, Red River, Lolo Creek separately and repeated measures analysis on all streams combined, 1985-1988.

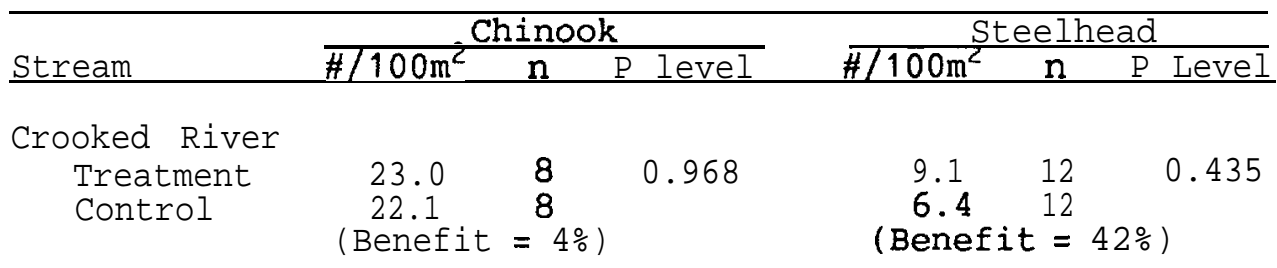

Red River

Treatment

Control

$\begin{array}{ccc}46.8 & 8 & 0.472 \\ 34.7 & 8 & \\ (\text { Benefit } & = & 35 \%)\end{array}$

$$
\begin{array}{ccc}
1.9 & 8 & 0.874 \\
2.1 & 8 & \\
\text { (Benefit } & = & -10 \% \text { ) }
\end{array}
$$

Lolo Creek

Treatment

Control

$$
\begin{array}{ccc}
20.2 & 12 & 0.033 * \\
17.0 & 12 &
\end{array}
$$

5. 612

0.421

3.812

(Benefit $=47 \%$ )

Combined

Treatment

Control

$\begin{array}{cll}28.6 & 28 & 0.733 \\ 23.5 & 28 & \\ \text { (Benefit } & = & 22 \% \text { ) }\end{array}$

5.5

$4.1 \quad 28 \quad 0.232$

4.128

(Benefit $=34 \%$ )

Table 34. Existing and potential weir site for monitoring passage of adult anadromous fish in Idaho.

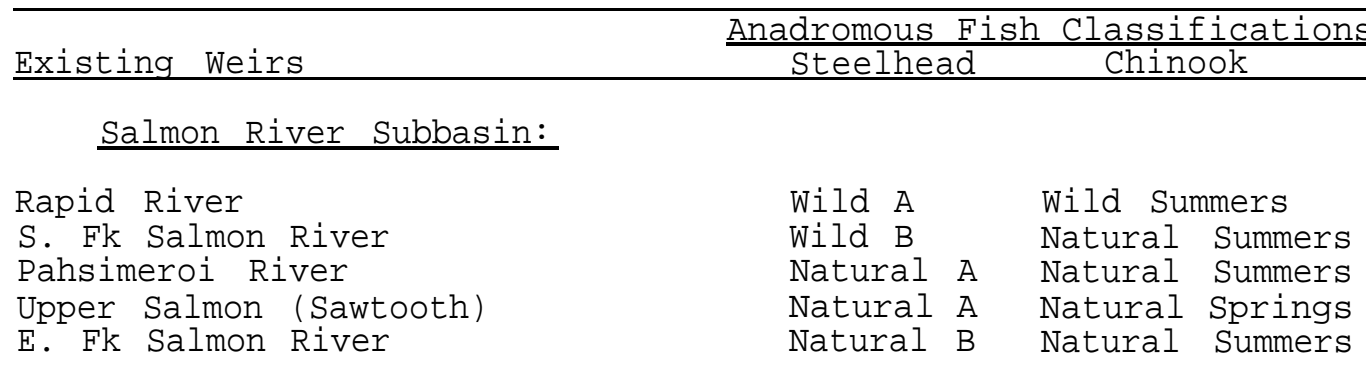

Clearwater River Subbasin:

Crooked River

Red River

Powel
Natural B Natural Springs

Natural B Natural Springs

Natural B Natural Springs

Additional weirs (potential sites)

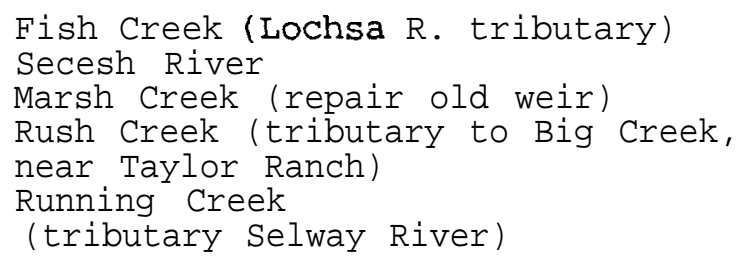

Natural Springs

Wild Summers

Wild Springs

Wild Summers (?)

Natural Springs 
endangered by continued low escapements. We need to know if the wild B-run stocks are continuing their decline, and if so, manage these stocks accordingly.

Concerning habitat enhancement projects, each year one or more project should be thoroughly evaluated. Projects selected for evaluation should be those which are complete and have been in place long enough to allow parr production benefits to accrue. Parr densities and habitat variables should be compared for pre- verses post-project and treatment verses control areas. In years when a project is not being evaluated, partial benefits will be based on changes in parr densities as estimated from a small number of monitoring sections.

The analyses done in this report on the benefits of instream structures in Lolo Creek, Red River, and Crooked River found a significant parr increase only in Lolo Creek, and there only for chinook. The analyses compared treatment and control densities, stratified by stream reaches and blocked by years over the life of the projects. A comparison was done also with strata from all three streams combined. No significant differences were found in this latter analysis. This contrasts with results of Clearwater Biostudies, Inc (1988) which found that the Lolo Creek instream structures had significant benefits for steelhead parr but not for chinook parr. Because of the inconsistent evaluation results, we give mitigation credit to increases in mean densities observed in the three streams where instream structures were evaluated. A final, conclusive evaluation is needed, based on a study design agreed upon by project implementors and evaluators in consultation with a university statistician. 


\section{ACKNOWLEDGEMENTS}

We appreciate the efforts of IDFG Regional Fisheries Managers Don Anderson, Bert Bowler, Jim Lukens, and Terry Holubetz and their assistants for conducting snorkel surveys in their respective regions during July and August of 1985-88. We also appreciate the same efforts from IDFG Research Biologists Tim Cochnauer and Bob Rohrer. Although part of the snorkel survey data were needed by these personnel, in addition to the needs of the BPA project, some data were collected specifically to complete the parr monitoring data set. 


\section{LITERATURE CITED}

Andrews, J. and L.B. Everson. 1988. Middle Fork and Upper Salmon River Habitat Improvement Implementation Plan, FY 1988-1992. BPA, Project 8424, \#DE-AI79-84BP17579. Bonneville Power Administration. Portland, OR.

Bonneville Power Administration (BPA). 1985. Columbia River Basin Fish and Wildlife Program work plan. Division of Fish and Wildlife, BPA. Portland, Oregon.

Chapman, D.W. 1988. Critical review of variables used to define effects of fines in redds of large salmonids. Transactions of the American Fisheries Society. 117:1-21.

Clearwater Biostudies, Inc. 1988. Fish habitat characteristics and salmonid abundance in the Lolo Creek study are during summer 1988. Prepared for U.S. Forest Service, Clearwater National Forest, Orofino, Idaho. P.O. No. 43-0276-8-219. 24 p. plus appendices.

Hankin, D.G., and G.H. Reeves. 1988. Estimating total fish abundance and total habitat area in small streams based on visual estimation methods. Can. J. Fish Aquat. Sci. 45:834-844.

Idaho Department of Fish and Game. 1984. Idaho anadromous fish management plan, 1984-1990 (draft). Idaho Department of Fish and Game. Boise, Id.

Kiefer, R.B. and K. Apperson. 1988. Intensive evaluation and monitoring of chinook salmon and steelhead trout production, Crooked River and Salmon River sites. Part IV in Idaho Department of Fish and Game. 1988. Idaho habitat evaluation of off-site mitigation record. Annual report, fiscal year 1987. Department of Energy, Bonneville Power Administration, Division of Fish and Wildlife.

Kiefer, R.B. and K. Forster. 1990. Intensive evaluation and monitoring of chinook salmon and steelhead trout production, Crooked River and Salmon River sites. Part II in Idaho Department of Fish and Game. 1990. Idaho habitat evaluation of off-site mitigation record. Annual report, fiscal year 1988. Department of Energy, Bonneville Power Administration, Division of Fish and Wildlife.

Konopacky, R.C., E.C. Bowles and P.J. Cernera. 1985. Salmon River habitat enhancement. Prepared for Bonneville Power Administration. Project No. 83-359. Shoshone-Bannock Tribes.

Lindland, R.L. and B. Bowler. 1986. Clearwater River Development of spring chinook and steelhead stocks Columbia River fisheries development program. Report to the National Marine Fisheries Service. Contract No. 85-ABH-00019. Idaho Department of Fish and Game, Boise, Id., 57 p. 
Northwest Power Planning Council. 1986. Columbia River basin fishery planning model-technical discussion paper. NWPPC.

Northwest Power Planning Council. 1987. Columbia River Basin Fish and Wildlife Program. Portland, Oregon. $246 \mathrm{p}$.

OEA (OEA research). 1987a. Upper Salmon River aquatic and riparian area inventories. Final Report. Department of Energy, Bonneville Power Administration, Division of Fish and Wildlife.

OEA (OEA research). 1987b. Middle Fork of the Salmon River, aquatic and riparian area inventories. Final Report. Department of Energy, Bonneville Power Administration, Division of Fish and Wildlife.

Petrosky, C.E. and T.B. Holubetz. 1985. Idaho habitat evaluation for off-site mitigation record. Annual report, fiscal year 1984. Department of Energy, Bonneville Power Administration, Division of Fish and Wildlife.

Petrosky, C.E. and T.B. Holubetz. 1986. Idaho habitat evaluation for off-site mitigation record. Annual report, fiscal year 1985. Department of Energy, Bonneville Power Administration, Division of Fish and Wildlife.

Petrosky, C.E. and T.B. Holubetz. 1987. Idaho habitat evaluation for off-site mitigation record. Annual report, fiscal year 1986. Department of Energy, Bonneville Power Administration, Division of Fish and Wildlife.

Petrosky, C.E. and T.B. Holubetz. 1988. Idaho habitat evaluation for off-site mitigation record. Annual report, fiscal year 1987. Department of Energy, Bonneville Power Administration, Division of Fish and Wildlife.

Ricker, W.E. 1975. Computation and interpretation of biological statistics of fish populations. Fisheries Research Board of Canada. Bulletin 119. Ottawa.

Rosgen, D.L. 1985. A stream classification system. North America Riparian Conference. Tucson, Arizona. April 16-18, 1985.

SYSTAT. 1988. SYSTAT: The system for statistics. Evanston, IL. SYSTAT, Inc.

Technical Advisory Committee (TAC). 1989. Columbia River Fish and Wildlife Authority, Portland, OR.

Thurow, R.T. 1987. Evaluation of the South Fork Salmon River steelhead trout fishery restoration program. Report to the U.S. Department of the Interior, Fish and Wildlife Service, Lower Snake River Fish and Wildlife Compensation Plan. Contract No. 14-16-0001-86505. Idaho Department of Fish and Game, Boise, ID. 154 p. 
Torquemada, R.J. and W.S. Platts. 1988. A Comparison of sediment monitoring techniques of potential use in sediment/fish population relationships. Part III in Idaho Department of Fish and Game, 1988. Idaho habitat evaluation for off-site mitigation record. Annual report, fiscal year 1987. Department of Energy, Bonneville Power Administration, Division of Fish and Wildlife.

White, L.E. 1980. Evaluation of a new planting device for salmon eggs. Progressive Fish Culturist 42(3):177-180. 
Appendix A-1 Monitoring section names and EPA stream reach locations, channel types ( $\mathbf{B}$ or $\mathbf{C}$ ), steelhead classification (wild or natural, A-run or B-run), chinook classification (wild or natural, springs or summers) and if chinook are monitored there.

St ream

Name

\begin{tabular}{|c|c|c|c|}
\hline ALTURAS LK CF & $C R$ & DS. DVRSN & 1A \\
\hline ALTURAS LK CP & $C R$ & DS. DVRSN & $1 \mathrm{~B}$ \\
\hline ALTURAS LK CR & $C R$ & DS. DVRSN & $1 \mathrm{C}$ \\
\hline ALTURAS LK CR & $C R$ & US. DVRSN & $2 \mathrm{~A}$ \\
\hline ALTURAS LK CA & $C R$ & US- DVRSN & 28 \\
\hline ALTURAS LK CR & $C R$ & US- LAKE & $3 \mathrm{~A}$ \\
\hline ALTURAS LK CP & $C R$ & US· LAKE & $3 B$ \\
\hline AMERI CAN R & & & 1 \\
\hline AMERI CAN R & & & 2 \\
\hline BARGAMIN CR & & & 19 \\
\hline BARGAMIN CR & & & L2 \\
\hline BEAR CR & & & 1 \\
\hline BEAR CR & & & 2 \\
\hline BEAR VALLEY & $C R$ & 1 & A \\
\hline BEAR VALLEY & $C R$ & 2 & $A$ \\
\hline BEAR VALLEY & $C R$ & 2 & B \\
\hline BEAR VALLEY & $C R$ & 3 & $A$ \\
\hline BEAR VALLEY & $C R$ & 5 & A \\
\hline BEAR VALLEY & $C R$ & 7 & $B I G-M O W-L$ \\
\hline BEAR VALLEY & $C R$ & 9 & B \\
\hline BEAR VALLEY & $C R$ & $\mathrm{HCl}$ & B \\
\hline BEARSKIN CR & & 1 & B \\
\hline BEAVER CR & & 1 & $A$ \\
\hline BEAVER CR & & 1 & 8 \\
\hline BEAVER CR & & 2 & $A$ \\
\hline BEAVER CR & & 2 & B \\
\hline BEAVER CR & & 3 & B \\
\hline BIG CANYON CR & $C R$ & & 1 \\
\hline$B \mid G \quad C R$ & & LOWE R & LI \\
\hline BIG CR & & MI DDLE & TAYLORI \\
\hline$B I G C R$ & & UPPER & $B \mid G 1$ \\
\hline BIG SPRINGS & $C R$ & LEM1 & A \\
\hline BOULDER CR & & ABOVE & 1 \\
\hline BOULDER CR & & ABOVE & 2 \\
\hline BOULDER CR & & BELOW & 3 \\
\hline BOULDER CR & & BELOW & 5 \\
\hline BRUSHY FK CR & & & 1 \\
\hline BRUSHY FK CR & & & 2 \\
\hline CAMAS CR & & & 1 \\
\hline CAMAS CR & & & 2 \\
\hline CAMAS CR & & & CAM1 \\
\hline CAMAS CR & & & LI \\
\hline CAPE HORN CR & & 1 & $A$ \\
\hline CAPE HORN CR & & 2 & B \\
\hline
\end{tabular}

EPA

$\begin{array}{lll} & \text { Stream } \\ \text { Stratum } & \text { Section } & \text { Reach }\end{array}$

1706020107700 1706020108100 1706020107700 1706020107700 1706020107700 1706020108100 1706020108100 1706030504100 1706030504100 1706020708000 1706020708000 1706030102400 1706030102400 1706020502300 1706020502500 1706020502500 1706020502700 1706020502800 1706020502800 1706020502800 1706020402600 1706020508400 1706020114700 1706020114700 1706020114700 1706020114700 1706020503600 1706030602200 1706020600700 1706020601100 1706020603200 1706020408300 1706021000900 1706021000900 1706021000900 1706021000900 1706030304300 1706030304300 1706020605200 1706020605200 1706020605200 1706020605100 1706020503400 1706020503400

$\begin{array}{llll} & \text { Steelhead } & \text { Chinook } & \text { Program } \\ & \text { Class: } & \text { Class: } & \text { Sampling } \\ \text { Channel } & \text { W vs N } & \text { W vs N } & \text { the } \\ \text { Type } & \text { A vs B } & \text { Spr vs Sum } & \text { Section }\end{array}$

NSPR

NSPR

NSPR

NSPR

NSPR

NSPR

NSPR

NSPR

NSPR

WSPR

WSPR

NSPR

NSPR

WSPR

WSPR

WS PR

WS PR

WSPR

WSPR

WSPR

NSPR

WS PR

NSPR

NSPR

NSPR

NSPR

WS PR

NSPR

WS PR

W S P R

WSPR

NSPR

NSPR

NSPR

NSPR

NSPR

NSPR

NSPR

WS PR

WSPR

WSPR

WSPR

WSPR

WSPR
I F M0 368713

I FM0 368713

I F M0 368713

IFM0368713

I F M0 368713

I FM0 368713

I F M0 368713

I FM0 368712

I F M0 368712

I R6

I R6

IR2

I R2

I F M0 368712

I F M0 368712

I F M0 368712

I F M0 368712

I F M0 368712

I FM0 368712

IFM0 368712

I F M0 368712

I FM0 368712

I F M0 368713

I FM0 368713

I F M0 368711

I F M0 36871:

IFMO36871ć

I R2

I R 6

IFM036871:

I $R 3$

IFMO36871:

IFM036871:

IFM036871:

IFM036871:

IFM036871:

IFR

IFR

If M036871;

I FM0 36871:

IFMO36871:

I R6

I F M0 36871:

I FM0 36871 


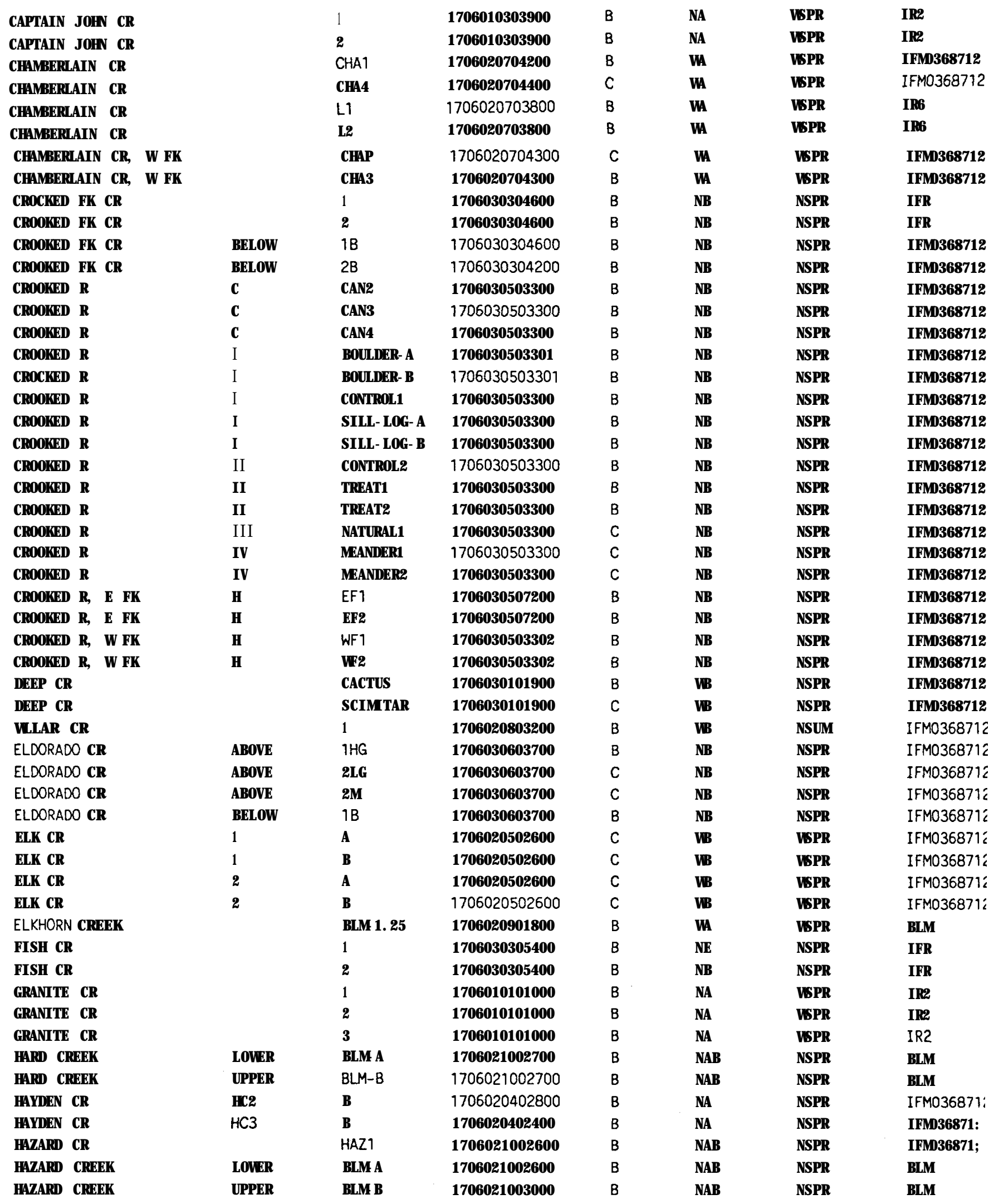


Appendix A-1 (Cont..)

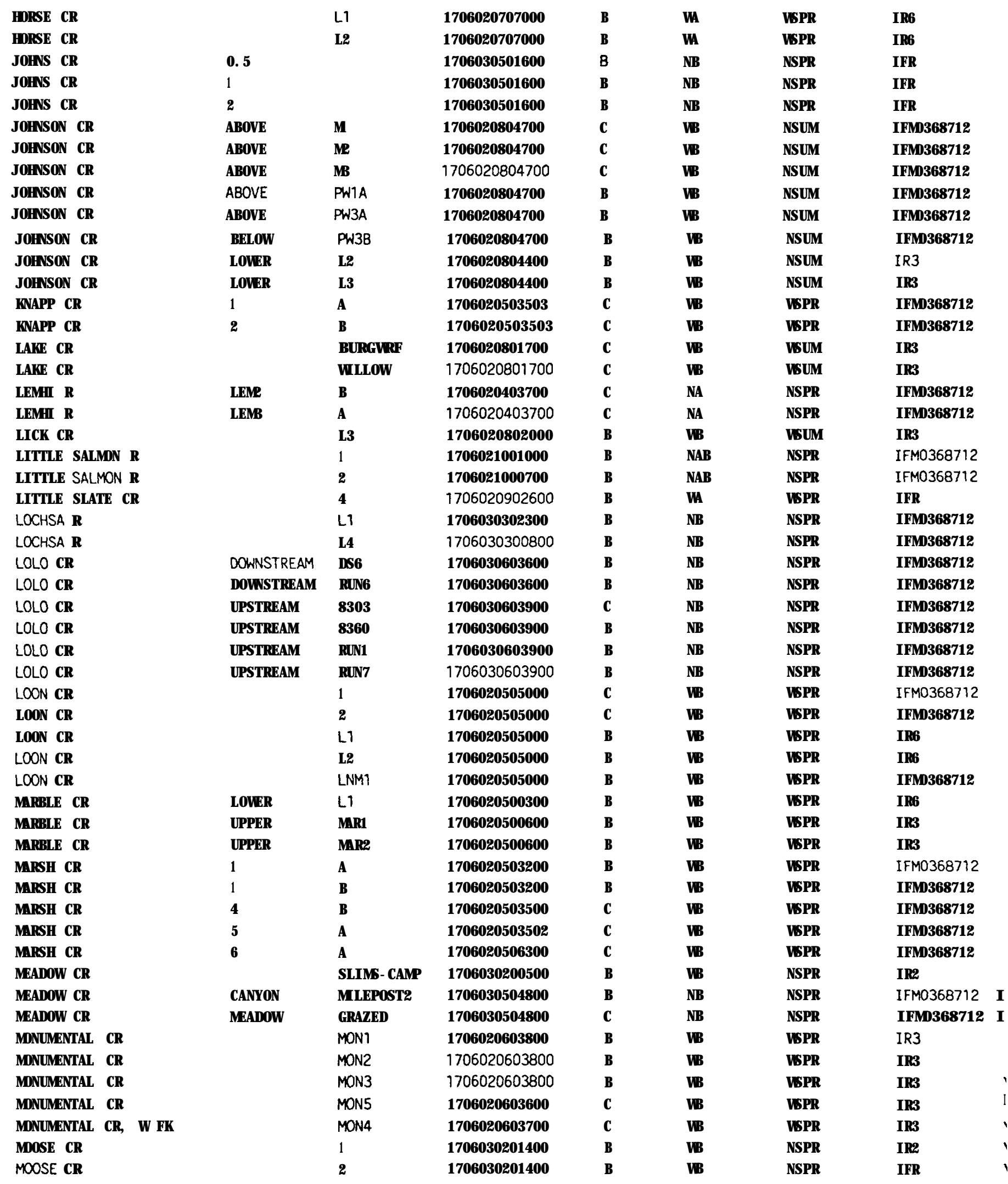


MOOSE CR

MOOSE CR, N FK

MORGAN CR

MOYER CR

NEWSOME CR

NEWSOME CR

NEWSOME CR

OLD MAN CR

OTTER CR

PAHSI MEROI R

PAHSI MEROI R

PANTHER CR

PANTHER CR

PANTHER CR

PANTHER CR

PANTHER CR

PISTOL CR

PISTOL CR

POLE CR

POLE CR

POLE CR

POLE CR

POLE CR

POLE CR

POLE CR

POLE CR

POLE CR

POLE CR

POST OFFICE CR

POST OFFICE CR

RAPID R

RAPID $R$, W FK

RED R

RED R

RED R

RED $R$

RED R

RED R

RED R

RED R

REDFISH LK CR

REDFISH LK CR

RELIEF CR

RELIEF CR

ROCK CR

RUNNING CR

RUNNING CR

SALMONR

SALMON R

SALMONR

SALMON $R$

SALMON R

SALMON R

\begin{tabular}{|c|c|c|}
\hline & 3 & 1706030201500 \\
\hline & 2 & 1706030203000 \\
\hline UPPER & BLL· CAMP & 1706020100200 \\
\hline \multirow[t]{3}{*}{ ABOVE } & MO1 & 1706020302300 \\
\hline & 1 & 1706030504300 \\
\hline & MOUTH & 1706030504300 \\
\hline \multirow[t]{5}{*}{ MAI N } & $4 \mathrm{MI}$ & 1706030504300 \\
\hline & & 1706030300600 \\
\hline & & 1706030201000 \\
\hline & DWTINLANE & 1706020200100 \\
\hline & LOWER & 1706020200100 \\
\hline ABOVE & $P C 10$ & 1706020302200 \\
\hline ABOVE & PC9 & 1706020302000 \\
\hline$D S \cdot B I G D$ & $\mathrm{PC} 4$ & 1706020301000 \\
\hline$D S \cdot B L A C K B$ & PC6 & 1706020301400 \\
\hline \multirow[t]{4}{*}{ DS. CLEAR } & $\mathrm{PCl}$ & 1706020300600 \\
\hline & 11 & 1706020501100 \\
\hline & $\mathrm{L} 2$ & 1706020501100 \\
\hline & $A$ & 1706020114900 \\
\hline I & $B$ & 1706020114900 \\
\hline II & $A$ & 1706020114900 \\
\hline II & B & 1706020114900 \\
\hline III & A & 1706020114900 \\
\hline III & 8 & 1706020114900 \\
\hline IV & $A$ & 1706020114900 \\
\hline IV & B & 1706020114900 \\
\hline V & A & 1706020114900 \\
\hline \multirow[t]{5}{*}{ V } & B & 1706020114900 \\
\hline & 1 & 1706030301800 \\
\hline & 2 & 1706030301800 \\
\hline & RAP2 & 1706021000200 \\
\hline & RAP1 & 1706021000300 \\
\hline I & CONTROL 1 & 1706030503600 \\
\hline I & CONTROL 2 & 1706030503800 \\
\hline II & CONTROL 2 & 1706030503800 \\
\hline II & TREAT 2 & 1706030503800 \\
\hline IV & CONTROL 2 & 1706030503600 \\
\hline IV & TREAT 2 & 1706030503600 \\
\hline V & CONTROL 2 & 1706030503600 \\
\hline \multirow[t]{3}{*}{$\mathrm{V}$} & TREAT 2 & 1706030503600 \\
\hline & LOWER & 1706020106100 \\
\hline & WE I R · DS & 1706020106100 \\
\hline RC & RELI EF-CRI & 1706030507100 \\
\hline$R C$ & RELI EF - CR2 & 1706030507100 \\
\hline \multirow[t]{4}{*}{ ABOVE } & $\mathrm{Ml}$ & 1706020809800 \\
\hline & 1 & 1706030100800 \\
\hline & 2 & 1706030100800 \\
\hline & RBNSN- BAR & 1706020103900 \\
\hline 10 & A & 1706020108400 \\
\hline 10 & $B$ & 1706020108400 \\
\hline 2 & $B$ & 1706020106000 \\
\hline 3 & $A$ & 1706020106900 \\
\hline 3 & $B$ & 1706020106900 \\
\hline
\end{tabular}

$\begin{array}{ll}\text { WB } & \text { NSP } \\ \text { WB } & \text { NSP } \\ \text { NA } & \text { NSP } \\ \text { NA } & \text { NSP } \\ \text { NB } & \text { NSP } \\ \text { NB } & \text { NSP } \\ \text { NB } & \text { NSP } \\ \text { NB } & \text { NSP } \\ \text { WB } & \text { NSP } \\ \text { NA } & \text { NSU } \\ \text { NA } & \text { NSU } \\ \text { NA } & \text { NSP } \\ \text { NA } & \text { NSP } \\ \text { NA } & \text { NSP }\end{array}$

NSPR
NSPR
NSPR
NSPR
NSPR
NSPR
NSPR
NSPR
NSPR
NSUM
NSUM
NSPR
NSPR
NSPR
NSP

NSPR

WSPR

WS PR

NSPR

NSPR

NSPR

NSPR

NSPR

NSPR

NSPR

NSPR

NSPR

NSPR

NSPR

NSPR

NSUM

NSUM

NSPR

NSPR

NSPR

NSPR

NSPR

NSPR

NSPR

NSPR

NSPR

NSPR

NSPR

NSPR

NSUM

NSPR

NSPR

WS UM

NSPR

NSPR

NSPR

NSPR

NSPR
IFR

I R2

I F M0 368712

I F M0 368712

I R2

FAO

FAO

IFR

IFR

IR6

I R6

I F M0 368712

I FM0 368712

I F M0 368712

I F MD3 68712

I F M0 368712

I $R 6$

IR6

I F M0 368713

I F M0 368713

I F M0 368713

I F M0 368713

I F M0 368713

I F M0 368713

I F M0 368713

IFM0368713

I F M0 368713

IF M0 368713

IFR

IFR

IFM0368712 IFM0368712 I F M0 368712

I F M0 368712

I F M0 368712

IFM0368712

I F M0 368712

IFM0368712

I F M0 368712

IFM0368712

I F M0 368712

IFM0368712

IFM0368712

IFM0368712

I F M0 368712

IR2

IR2

I F M0 368712

I FM0 368713

I F M0 368713

I F MD368713

IFM0368713

IFM0368713 
Appendix A-1. (Cont.)

\begin{tabular}{|c|c|c|c|c|c|c|c|c|}
\hline SALMON & $R$ & 3 & BRA & 1706020106900 & C & NA & NSPR & I F M0 368713 \\
\hline SALMON & $R$ & 3 & BRB & 1706020106900 & c & NA & NSPR & I FM0 368713 \\
\hline SALMON & $R$ & 3 & $B R B \cdot R C H$ & 1706020106900 & c & NA & NSPR & I FM0368713 \\
\hline SALMON & R & 4 & A & 1706020107001 & c & NA & NSPR & I F M0 368713 \\
\hline SALMON & R & 4 & B & 1706020107100 & c & NA & NSPR & I F M0 368713 \\
\hline SALMONF & & 4 & BRA & 1706020107000.5 & c & NA & NSPR & I FM0368713 \\
\hline SALMON & $R$ & 4 & BRB & 1706020107000 & C & NA & NSPR & I FM0 368713 \\
\hline SALMON & $R$ & 5 & $A$ & 1706020107100 & B & NA & NSPR & I FM0 368713 \\
\hline SALMON & R & 5 & B & 1706020107500 & B & NA & NSPR & I FM0 368713 \\
\hline SALMON & $R$ & 6 & $A$ & 1706020107501 & c & NA & NSPR & I FM0 368713 \\
\hline SALMON & R & 6 & B & 1706020107501 & B & NA & NSPR & I F M0 368713 \\
\hline SALMON & $R$ & 7 & $A$ & 1706020108200 & C & NA & NSPR & I FM0 368713 \\
\hline SALMON & $R$ & 1 & B & 1706020108200 & c & NA & NSPR & I F M0 368713 \\
\hline SALMON & R & 8 & $A$ & 1706020108200 & c & NA & NSPR & I F M0 368713 \\
\hline SALMON & $R$ & 8 & B & 1706020108200 & c & NA & NSPR & I FM0 368713 \\
\hline SALMON & $R$ & 9 & A & 1706020108400 & c & NA & NSPR & I FM0 368713 \\
\hline SALMON & R & 9 & 8 & 1706020108400 & B & NA & NSPR & I FM0 368713 \\
\hline SALMON & $R$, E FK & ABOVE - WEI R & 2 & 1706020110700 & c & NAB & NSPR & I FM0 368712 \\
\hline SALMON & $R$, E FK & ABOVE - WEI R & 3 & 1706020110700 & c & NAB & NSPR & I FM0 368712 \\
\hline SALMON & $R$, E FK & BEL OW. WEI R & 5 & 1706020110300 & c & NAB & NSPR & IFM0368712 \\
\hline SALMON & $R$, E F K & BEL OW. WE I R & 8 & 1706020109800 & C & NAB & NSPR & I F M0 368712 \\
\hline SALMON & $R$, N F K & & DAHL ONEGA & 1706020307700 & B & NA & NSPR & I F M0 368712 \\
\hline SALMON & $R$, N F K & & HUGHES & 1706020307500 & C & NA & NSPR & I F M0 368712 \\
\hline SALMON & $R$, S FK & & 11 & 1706020802900 & B & WB & NSUM & I R3 \\
\hline SALMON & $R$, S FK & & 14 & 1706020802400 & B & WB & NSUM & I R3 \\
\hline SALMON & $R$, S FK & & 16 & 1706020802200 & B & WB & NSUM & I R3 \\
\hline SALMON & $R$ ， S F K & & 5 & 1706020803400 & c & WB & NSUM & I R3 \\
\hline SALMON & $R$, S FK & & & 1706020803300 & B & WB & NSUM & I R3 \\
\hline SALMON & $R$, S FK & & POVERTY & 1706020802900 & c & WB & NSUM & I FM0 368712 \\
\hline SALMON & $R$, S F K & STOLLE & & 1706020803600 & c & WB & NSUM & IFM0368712 \\
\hline SALMON & $R$ ， S F K & STOLLE & 2 & 1706020803600 & c & WB & NSUM & IFM0368712 \\
\hline SALMON & $R$, S FK E FK & & 3 & 1706020805100 & B & WB & NSUM & I R3 \\
\hline SALMON & $R$, S FK E FK & & 6 & 1706020804300 & B & WB & NSUM & I R3 \\
\hline SALMON & $R$ ， S FK E FK & & & 1706020804200 & B & WB & NSUM & I R3 \\
\hline SAND CR & & ABOVE & M2 & 1706020807400 & C & WB & NSUM & I F M0 368712 \\
\hline SECESH & R & & GROUSE & 1706020801601 & B & WB & WS UM & I R3 \\
\hline SECESH & R & & LONG. GULCH & 1706020801601 & C & WB & WS UM & I R3 \\
\hline SECESH & R & & U-SCSH-MDW & 1706020801601 & c & WB & WS UM & I R3 \\
\hline SELWAY & R & & HELLSHALF & 1706030101400 & B & WB & NSPR & I F M0 368712 \\
\hline SELWAY & R & & LITTLE-CW & 1706030101300 & $\mathrm{~B}$ & WB & NSPR & I FM0 368712 \\
\hline SELWAY & R & & MAG $=X I N G$ & 1706030101300 & c & WB & NSPR & I F M0 368712 \\
\hline SHEEP C & $C R$ & & & 1706010101300 & 8 & WA & WS PR & IR2 \\
\hline SHEEP C C & $C R$ & & 2 & 1706010101300 & B & WA & WS PR & IR2 \\
\hline SHEEP C & $C R$ & & L1 & 1706020709300 & B & WA & WS PR & I R6 \\
\hline SHEEP C C & $C R$ & & $\mathrm{~L} 2$ & 1706020709300 & B & WA & WS PR & I R6 \\
\hline SLATE C & $C R$ & & & 1706020902500 & B & WA & WS PR & IFR \\
\hline SLATE C & $C R$ & & 2 & 1706020902500 & B & WA & WS PR & IFR \\
\hline STATE C & $C R$ & & 3 & 1706020902500 & B & WA & WS PR & IFR \\
\hline SLATE C & $C R$ & 12.1 & & 1706020902500 & B & WA & WS PR & IFR \\
\hline SLATE C & $C R$ & 4.3 & & 1706020902500 & B & WA & WS PR & IFR \\
\hline SLATE C & $C R$ & 6.7 & & 1706020902500 & B & WA & WSPR & IFR \\
\hline
\end{tabular}


Appendix A-1. (Cont.)

\begin{tabular}{|c|c|c|c|c|c|c|c|}
\hline SLATE CR & 8.1 & & 1706020902500 & B & WA & WSPR & IFR \\
\hline SMILEY CR & & A & 1706020108300 & B & NA & NSPR & I FM0 368713 \\
\hline SMILEY CR & . & B & 1706020108300 & c & NA & NSPR & I F M0 368713 \\
\hline SMILEY CR & 2 & A & 1706020108300 & c & NA & NSPR & I FM0368713 \\
\hline SMILEY CR & 2 & B & 1706020108300 & c & NA & NSPR & I F M0 368713 \\
\hline SULPHUR CR & 3 & A & 1706020502100 & B & WB & WSPR & I F M0 368712 \\
\hline SULPHUR CR & 4 & $A$ & 1706020502100 & c & WB & WSPR & I F M0 368712 \\
\hline SULPHUR CR & 4 & B & 1706020502100 & c & WB & WSPR & IFM0368712 \\
\hline THREE LINKS CR & & & 1706030203900 & B & WB & NSPR & IFR \\
\hline VALLEY CR & & B & 1706020105200 & c & NA & NSPR & I F M0 368712 \\
\hline VALLEY CR & 3 & A & 1706020105300 & c & NA & NSPR & IFM0368712 \\
\hline VALLEY CR & 3 & B & 1706020105400 & c & NA & NSPR & I F M0 368712 \\
\hline VALLEY CR & 6 & 8 & 1706020105500 & 8 & NA & NSPR & IFM0368712 \\
\hline WARM SPRINGS CR & & & 1706030301900 & B & NB & NSPR & IFR \\
\hline WHITE CAP CR & & BRI DGE & 1706030102100 & B & WB & NSPR & I F M0368712 \\
\hline WHITE CAP CR & & UPPER & 1706030102100 & B & WB & NSPR & I F MD368712 \\
\hline WHI TE CAP CR & & WI LDERNESS & 1706030102100 & B & WB & NSPR & I F M0 368712 \\
\hline WHI TE SAND CR & LOWER & WS1 & 1706030302700 & B & NB & NSPR & I F M0368712 \\
\hline WHI TEBI RD CR & & & 1706020902900 & B & WA & WSPR & IFR \\
\hline WHI TEBI RD CR & & 2 & 1706020903000 & B & WA & WSPR & IFR \\
\hline WHI TEBIRD CR & & 3 & 1706020903000 & B & WA & WSPR & IFR \\
\hline WHI TEBIRD CR, N FK & & 2 & 1706020903100 & B & WA & WSPR & IFR \\
\hline WHITEBIRD CR，S FK & & 3 & 1706020903000 & B & WA & WS PR & IFR \\
\hline WHI TEBIRD CR, S FK & & 4 & 1706020903000 & B & WA & WS PR & IFR \\
\hline WOLF CR & & & 1706010101400 & B & WA & WS PR & I R2 \\
\hline
\end{tabular}


Appendix A-2. Main stem rivers and sections where corridor snorkeling is done. EPA reach and steelhead and chinook classifications are listed.

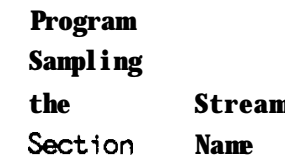

$\begin{array}{ll}\text { ** Program If R } \\ \text { IF R } & \text { LOCHSA R } \\ \text { IF R } & \text { LOCHSA R } \\ \text { IFR } & \text { LOCHSA R } \\ \text { IFR } & \text { LOCHSA R }\end{array}$

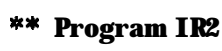

\begin{tabular}{|c|c|}
\hline IR2 & SELWAY \\
\hline IR2 & SELWAY \\
\hline I R2 & SELWAY \\
\hline I R2 & SELWAY \\
\hline IR2 & SELWAY \\
\hline I R2 & SEL WAY \\
\hline I R2 & SELWAY \\
\hline
\end{tabular}

\begin{tabular}{lll} 
& & \multicolumn{2}{l}{ Steelhead Chinook } \\
& EPA & Class: Class: \\
& Stream & W vs N W Ws N \\
Stratum Section & Reach & A vs B Spr vs Sum
\end{tabular}

$\begin{array}{lccc}\text { DI VIDE } & 1706030100700 & \text { WB } & \text { NSPR } \\ \text { HALFWAY } & 1706030100700 & \text { WB } & \text { NSPR } \\ \text { LADLE } & 1706030100700 & \text { WB } & \text { NSPR } \\ \text { MAI DEN } & 1706030100700 & \text { WB } & \text { NSPR } \\ \text { RENSHAW } & 1706030100700 & \text { WB } & \text { NSPR } \\ \text { RUN. BRI DGE } & 1706030100900 & \text { WB } & \text { NSPR } \\ \text { RUN-CR.PL } & 1706030100700 & \text { WB } & \text { NSPR }\end{array}$

$\begin{array}{llll}18 & 1706020801000 & \text { WB } & \text { NSUM } \\ 19 & 1706020801000 & \text { WB } & \text { NSUM } \\ 20 & 1706020800800 & \text { WB } & \text { NSUM } \\ 21 & 1706020800600 & \text { WB } & \text { NSUM } \\ 22 & 1706020800300 & \text { WB } & \text { NSUM } \\ 24 & 1706020800200 & \text { WB } & \text { NSUM } \\ 25 & 1706020800100 & \text { WB } & \text { NSUM } \\ 26 & 1706020800100 & \text { WB } & \text { NSUM } \\ 28 & 1706020800100 & \text { WB } & \text { NSUM }\end{array}$

$\begin{array}{llll}\text { BOUNDARY } & 1706020502200 & \text { WB } & \text { WSPR } \\ \text { ELKHORN } & 1706020501800 & \text { WB } & \text { WSPR } \\ \text { GRDLHOLE } & 1706020502000 & \text { WB } & \text { WSPR } \\ \text { GREYHOUND } & 1706020501700 & \text { WB } & \text { WSPR } \\ \text { I NDI AN } & 1706020501000 & \text { WB } & \text { WSPR } \\ \text { RAPI D.R } & 1706020501600 & \text { WB } & \text { WSPR } \\ \text { SHEEPEATER } & 1706020501800 & \text { WB } & \text { WSPR } \\ \text { VELVET } & 1706020502000 & \text { WB } & \text { WSPR } \\ \text { COUGAR } & 1706020500100 & \text { WB } & \text { WSPR } \\ \text { HOSPPL } & 1706020605000 & \text { WB } & \text { WSPR } \\ \text { HOSPRUN } & 1706020605000 & \text { WB } & \text { WSPR } \\ \text { LJACKASS } & 1706020500200 & \text { WB } & \text { WSPR } \\ \text { MARBLPL } & 1706020500800 & \text { WB } & \text { WSPR } \\ \text { PUNGO } & 1706020500800 & \text { WB } & \text { WSPR }\end{array}$


Appendix A-2. (Cont.)

\begin{tabular}{|c|c|c|c|c|c|c|}
\hline I R6 & SALMON R， M FK & II & ROCKIS & 1706020500100 & WB & WSPR \\
\hline I R6 & SALMON $R, M F K$ & II & SKIJUMP & 1706020500200 & WB & WSPR \\
\hline I R6 & SALMON R, M FK & II & TAPPANPOOL & 1706020605000 & WB & WSPR \\
\hline I R6 & SALMON $R, M F K$ & II & TAPPANRUN & 1706020605000 & WB & WSPR \\
\hline IR6 & SALMON R, M FK & II & WHI TEYCX & 1706020500100 & WB & WS PR \\
\hline IR6 & SALMON R, M FK & III & AI RSTRI P & 1706020604700 & WB & WS PR \\
\hline IR6 & SALMON R, M FK & III & F L YI NG. B & 1706020604700 & WB & WSPR \\
\hline I R6 & SALMON R, M FK & III & SURVEY & 1706020604500 & WB & WS PR \\
\hline IR6 & SALMON R, M FK & IV & $B \mid G \cdot C R \cdot B R$ & 1706020604400 & WB & WSPR \\
\hline I R6 & SALMON $R, M F K$ & IV & GOATPOOL & 1706020600200 & WB & WSPR \\
\hline I R6 & SALMON $R, M F K$ & IV & GOATRUN & 1706020600200 & WB & WS PR \\
\hline | R6 & SALMON R, M FK & IV & LITOUZEL & 1706020600300 & WB & WS PR \\
\hline | R6 & SALMON R, M FK & IV & LOVEBAR & 1706020600600 & WB & WSPR \\
\hline I R6 & SALMON R, M FK & IV & OTTERBAR & 1706020600300 & WB & WSPR \\
\hline IR6 & SALMON R, M FK & IV & SHIPISLAND & 1706020600300 & WB & WSPR \\
\hline
\end{tabular}


Appendix A-3. Summary of hatchery chinook releases (in thousands) into natural production areas for BPA habitat project and monitoring streams, 1984.1988.

\begin{tabular}{|c|c|c|c|c|c|c|c|}
\hline Stream & Race $^{a}$ & Size & 1984 & 1985 & 1986 & 1987 & 1988 \\
\hline \multirow[t]{4}{*}{ Lo10 Creek } & $\mathrm{SP}$ & egg & 0 & 0 & 0 & 0 & 0 \\
\hline & & fry & 0 & 0 & 0 & 133 & 148 \\
\hline & & s molt & 0 & 0 & 0 & 0 & 0 \\
\hline & & $a d u l t$ & 0 & 0 & 0 & 0 & 0 \\
\hline \multirow[t]{4}{*}{ Eldorado Creek } & SP & egg & 0 & 0 & 0 & 0 & 0 \\
\hline & & fry & 0 & 0 & 270 & 119 & 53 \\
\hline & & smolt & 0 & 0 & 0 & 0 & 0 \\
\hline & & adult & 0 & 0 & 0 & 0 & 0 \\
\hline \multirow[t]{4}{*}{ Crooked Fork $\mathrm{Cr}$. } & $S P$ & egg & 0 & 0 & 0 & 0 & 0 \\
\hline & & fry & 0 & 0 & 200 & 349 & 138 \\
\hline & & s mol t & 0 & 0 & 0 & 0 & 0 \\
\hline & & adult & 0 & 0 & 0 & 0 & 0 \\
\hline \multirow{4}{*}{ Crooked River } & $S P$ & egg & 0 & 0 & 0 & 50 & 0 \\
\hline & & fry & 0 & 0 & 350 & 0 & 200 \\
\hline & & s molt & 0 & 0 & 0 & 479 & 0 \\
\hline & & adult & 0 & 0 & 0 & 0 & 0 \\
\hline \multirow[t]{4}{*}{ Red River } & SP & egg & 0 & 0 & 0 & 331 & 0 \\
\hline & & fry & 0 & 0 & 0 & 0 & 50 \\
\hline & & s molt & 0 & 80 & 137 & 195 & 0 \\
\hline & & adult & 0 & 0 & 0 & 0 & 0 \\
\hline \multirow[t]{4}{*}{ Meadow Creek } & $S P$ & egg & 0 & 0 & 0 & 0 & 0 \\
\hline & & fry & 0 & 0 & 0 & 0 & 100 \\
\hline & & smolt & 0 & 0 & 0 & 0 & 0 \\
\hline & & adul t & 0 & 0 & 0 & 0 & 0 \\
\hline \multirow[t]{4}{*}{ Panther Creek } & $S P$ & egg & 0 & 0 & 0 & 137 & 0 \\
\hline & & fry & 0 & 0 & 0 & 0 & 0 \\
\hline & & $\mathrm{smol} \mathrm{t}$ & 0 & 0 & 0 & 0 & 0 \\
\hline & & $a d u l t$ & 0 & 0 & 3.38 & 0 & 0 \\
\hline \multirow[t]{4}{*}{ Lemhi River } & $S P$ & egg & 0 & 0 & 0 & 0 & 0 \\
\hline & & fry & 0 & 0 & 1 & 0 & 0 \\
\hline & & $s \mathrm{molt}$ & 0 & 0 & 0 & 0 & 0 \\
\hline & & adult & 0 & 0 & 0.02 & 0 & 0 \\
\hline \multirow[t]{4}{*}{ E, Fk, Salmon R, } & SP & egg & 0 & 0 & 0 & 0 & 0 \\
\hline & & fry & 0 & 0 & 1 & 0 & 0 \\
\hline & & s molt & 0 & 0 & 109 & 195 & 249 \\
\hline & & adult & 0 & 0 & 0 & 0 & 0 \\
\hline \multirow[t]{4}{*}{ Upper Sal mon $R$. } & $S P$ & egg & 0 & 0 & 0 & 0 & 0 \\
\hline & & fry & 0 & 0 & 0 & 0 & 0 \\
\hline & & smolt & 231 & 420 & 348 & 1,185 & 1,605 \\
\hline & & $a d u l t$ & 0 & 0 & 0 & 0.01 & 0 \\
\hline \multirow[t]{4}{*}{ Alturas Lake $\mathrm{Cr}$. } & $S P$ & egg & 0 & 0 & 0 & 0 & 0 \\
\hline & & fry & 0 & 0 & 0 & 0 & 0 \\
\hline & & s molt & 0 & 0 & 0 & 0 & 0 \\
\hline & & $a d u l t$ & 0 & 0 & 0 & 0 & 0 \\
\hline
\end{tabular}


Appendix A-3. Continued.

\begin{tabular}{|c|c|c|c|c|c|c|c|}
\hline Stream & Race $^{\mathrm{a}}$ & $\mathrm{Size}$ & 1984 & 1985 & 1986 & 1987 & 1988 \\
\hline \multirow[t]{4}{*}{ Pole Creek } & SP & egg & 0 & 0 & 0 & 0 & 0 \\
\hline & & fry & 0 & 0 & 0 & 0 & 24 \\
\hline & & s molt & 0 & 0 & 0 & 0 & 0 \\
\hline & & adult & 0 & 0 & 0 & 0 & 0 \\
\hline \multirow[t]{4}{*}{ Valley Creek } & SP & egg & 0 & 0 & 0 & 0 & 0.0 \\
\hline & & fry & 0 & 0 & 0 & 0 & 0 \\
\hline & & $\mathrm{s} \mathrm{molt}$ & 0 & 0 & 0 & 0 & 0 \\
\hline & & adul t & 0 & 0 & 0 & 0 & 0 \\
\hline \multirow[t]{4}{*}{ S. Fk, Salmon R, } & su & egg & 0 & 0 & 3 & 0 & 0 \\
\hline & & fry & 0 & 0 & 0 & 0 & 0 \\
\hline & & smolt & 270 & 564 & 970 & 958 & 1,060 \\
\hline & & adult & 0 & 0 & 0 & 0 & 0 \\
\hline \multirow[t]{4}{*}{ Dollar Creek } & su & egg & 0 & 0 & 0 & 0 & 0 \\
\hline & & fry & 0 & 0 & 0 & 0 & 0 \\
\hline & & $\mathrm{s} \mathrm{molt}$ & 0 & 0 & 0 & 0 & 0 \\
\hline & & adult & 0 & 0 & 0 & 0 & 0 \\
\hline \multirow[t]{4}{*}{ Johnson Creek } & su & egg & 0 & 0 & 0 & 0 & 0 \\
\hline & & fry & 0 & 51 & 178 & 118 & 367 \\
\hline & & $\mathrm{s} \mathrm{mol} \mathrm{t}$ & 0 & 0 & 0 & 0 & 0 \\
\hline & & adult & 0 & 0 & 0 & 0 & 0 \\
\hline \multirow[t]{4}{*}{ Boulder Creek } & SP & egg & 0 & 0 & 0 & 140 & 141 \\
\hline & & fry & 0 & 0 & 101 & 0 & 0 \\
\hline & & $\mathrm{s} \mathrm{mol} \mathrm{t}$ & 0 & 0 & 0 & 0 & 0 \\
\hline & & adult & 0 & 0 & 0 & 0 & 0 \\
\hline \multirow[t]{4}{*}{ Little Salmon R. } & $S P$ & egg & 0 & 0 & 0 & 0 & 0 \\
\hline & & fry & 0 & 0 & 0 & 0 & 30 \\
\hline & & s mol t & 0 & 0 & 0 & 0 & 0 \\
\hline & & adult & 0 & 0 & 0 & 0 & 0 \\
\hline
\end{tabular}

asP=spring chinook; SUl=summer chinook. 
Appendix A.4. Summary of hatchery steel head releases (in thousands) into natural production areas for BPA habitat project and monitoring streams, $1984-1988$.

\begin{tabular}{|c|c|c|c|c|c|c|c|}
\hline$\underline{\text { Stream }}$ & Race $^{a}$ & $\mathrm{Size}$ & 1984 & 1985 & 1986 & 1987 & 1988 \\
\hline \multirow[t]{4}{*}{ Lo10 Creek } & SB & egg & 0 & 0 & 0 & 0 & 0 \\
\hline & & fry & 0 & 0 & 0 & 0 & 0 \\
\hline & & $\mathrm{smolt}$ & 0 & 0 & 0 & 0 & 200 \\
\hline & & $a d u ! t$ & 0 & 0 & 0 & 0 & 0 \\
\hline \multirow[t]{4}{*}{ Eldorado Creek } & SB & egg & 0 & 0 & 0 & 0 & 0 \\
\hline & & fry & 0 & 0 & 0 & 0 & 0 \\
\hline & & smo!t & 0 & 121 & 197 & 0 & 201 \\
\hline & & adu $7 t$ & 0 & 1.15 & 0.15 & 0 & 0 \\
\hline \multirow[t]{4}{*}{ Crooked Fork $\mathrm{Cr}$. } & SB & egg & 0 & 0 & 0 & 0 & 0 \\
\hline & & fry & 0 & 0 & 0 & 0 & 0 \\
\hline & & s mo $7 t$ & 0 & 0 & 0 & 0 & 0 \\
\hline & & adu $1 t$ & 0 & 0 & 0 & 0 & 0 \\
\hline \multirow[t]{4}{*}{ Colt Creek } & SB & egg & 0 & 0 & 0 & 0 & 0 \\
\hline & & fry & 0 & 0 & 0 & 0 & 0 \\
\hline & & $s \mathrm{mo} ! t$ & 0 & 0 & 0 & 0 & 0 \\
\hline & & adult t & 0 & 0 & 0 & 0 & 0 \\
\hline \multirow[t]{4}{*}{ Crooked River } & SB & egg & 0 & 0 & 0 & 0 & 0 \\
\hline & & fry & 0 & 0 & 88 & 0 & 0 \\
\hline & & s molt & 34 & 42 & 141 & 159 & 201 \\
\hline & & $a d u l t$ & 0 & 1.73 & 0 & 5.2 & 0 \\
\hline \multirow[t]{4}{*}{ Red River } & SB & egg & 0 & 731 & 0 & 0 & 182 \\
\hline & & fry & 0 & 0 & 0 & 0 & 0 \\
\hline & & $s \mathrm{molt}$ & 74 & 80 & 0 & 0 & 0 \\
\hline & & adult & 0 & 0 & 0 & 0 & 0 \\
\hline \multirow[t]{4}{*}{ Meadow Creek } & SB & egg & 0 & 0 & 0 & 770 & 1,022 \\
\hline & & fry & 0 & 0 & 0 & 0 & 0 \\
\hline & & smolt & 0 & 0 & 0 & 0 & 0 \\
\hline & & adult & 0 & 0 & 0 & 0 & 0 \\
\hline \multirow[t]{4}{*}{ Panther Creek } & SA & egg & 0 & 0 & 0 & 0 & 0 \\
\hline & & fry & 305 & 485 & 625 & 378 & 0 \\
\hline & & $\mathrm{s} \mathrm{mol} \mathrm{t}$ & 0 & 208 & 246 & 300 & 237 \\
\hline & & $a d u l t$ & 0.68 & 0.15 & 0.12 & 0 & 0 \\
\hline \multirow[t]{4}{*}{ Pine Creek } & SA & egg & 0 & 0 & 0 & 0 & 0 \\
\hline & & fry & 25 & 0 & 0 & 0 & 0 \\
\hline & & $\mathrm{s} \mathrm{mol} \mathrm{t}$ & 0 & 0 & 0 & 0 & 0 \\
\hline & & adult & 0 & 0 & 0 & 0 & 0 \\
\hline \multirow[t]{4}{*}{ Lemhi River } & $S A$ & egg & 0 & 0 & 0 & 0 & 0 \\
\hline & & fry & 270 & 923 & 718 & 185 & 175 \\
\hline & & $\mathrm{s} \mathrm{mol} \mathrm{t}$ & 0 & 0 & 0 & 0 & 0 \\
\hline & & $a d u l t$ & 4.28 & 0.87 & 0.68 & 1.01 & 0 \\
\hline \multirow[t]{4}{*}{ E, Fk, Sal mon R, } & $S B$ & egg & 0 & 0 & 0 & 0 & 0 \\
\hline & & fry & 0 & 19 & 789 & 0 & 0 \\
\hline & & smolt & 426 & 270 & 495 & 485 & 304 \\
\hline & & adult & 0 & 0 & 0.42 & 0.05 & 0 \\
\hline
\end{tabular}


Appendix A. 4, Continued.

\begin{tabular}{|c|c|c|c|c|c|c|c|}
\hline Stream & Race $^{\mathrm{a}}$ & Size & 1984 & 1985 & 1986 & 1987 & 1988 \\
\hline \multirow[t]{4}{*}{ Upper Sal mon $R$. } & SA & egg & 0 & 0 & 0 & 0 & 0 \\
\hline & & fry & 0 & 503 & 533 & 0 & 327 \\
\hline & & smolt & 724 & 786 & 637 & 688 & 1,253 \\
\hline & & adul t & 2.66 & 0 & 0 & 0 & $0.0 \xi$ \\
\hline \multirow[t]{4}{*}{ Alturas Lake $\mathrm{Cr}$. } & SA & egg & 0 & 0 & 0 & 0 & 0 \\
\hline & & fry & 0 & 32 & 300 & 175 & 105 \\
\hline & & $\mathrm{smolt}$ & 0 & 0 & 0 & 0 & 0 \\
\hline & & adult & 0 & 0 & 0 & 0 & 0 \\
\hline \multirow[t]{4}{*}{ Pole Creek } & SA & egg & 0 & 0 & 0 & 0 & 0 \\
\hline & & fry & 318 & 488 & 349 & 189 & 106 \\
\hline & & s mol t & 0 & 0 & 0 & 0 & 0 \\
\hline & & $a d u l t$ & 0 & 0 & 0 & 0 & 0 \\
\hline \multirow[t]{4}{*}{ Valley Creek } & SA & egg & 0 & 0 & 0 & 0 & 0 \\
\hline & & fry & 215 & 173 & 0 & 142 & 201 \\
\hline & & $s \mathrm{~mol} t$ & 0 & 0 & 0 & 0 & 0 \\
\hline & & adult & 1.55 & 0.10 & 0.52 & 0 & 0 \\
\hline \multirow[t]{4}{*}{ Boulder Creek } & SA & egg & 0 & 0 & 0 & 0 & 0 \\
\hline & & fry & 149 & 0 & 27 & 0 & 0 \\
\hline & & $\mathrm{s} \mathrm{mol} \mathrm{t}$ & 0 & 0 & 0 & 0 & 0 \\
\hline & & adult & 0 & 0 & 0 & 0 & 0 \\
\hline \multirow[t]{4}{*}{ Little Salmon R. } & SA & egg & 0 & 0 & 0 & 0 & 0 \\
\hline & & fry & 0 & 82 & 126 & 0 & 0 \\
\hline & & $s \mathrm{~mol} t$ & 0 & 0 & 0 & 0 & 0 \\
\hline & & $\mathrm{adult}$ & 0 & 0 & 0 & 0 & 0 \\
\hline
\end{tabular}

$a_{S A}=A-$ run steel head; $S B=B \cdot r$ un steel head. 
Appendix B. Mitigation benefits from habitat enhancement project.

The following (16) sections describe habitat enhancement projects, surface areas affected, and parr production from each project. Int the 1989 annual report, project benefits will be described in terms of smolt production, based on parr-to-smolt survival rates determined by the Intensive Evaluation and Monitoring section of project 83-7.

Appendix B-1. Proposed definition of mitigation benefits for implemented projects on Lo10 Creek.

\section{Project Type: Instream Structures}

Year Implemented: $1983-1984$

Sponsor: Clearwater National Forest

\begin{tabular}{|c|c|c|}
\hline \multirow[b]{2}{*}{ Enhancement } & \multicolumn{2}{|c|}{ Species Benefited } \\
\hline & B-Run Steelhead & Spring Chinook \\
\hline $\begin{array}{l}\text { Production Type: } \\
\text { Hectares Enhanced: }\end{array}$ & natural & natural \\
\hline & $\angle Z .3$ & \\
\hline
\end{tabular}

Production Constraints: High sediment levels

Definition of Benefits: Statistical comparison of steelhead and chinook parr densities in treated and untreated sections will be done at 3-to S-year intervals to determine the difference in densities. Parr density benefits are determined by subtracting control density from treatment density.

Evaluations were conducted in 1984 and 1985 at relatively low parr abundance. The 1985 evaluation determined that sections with structures supported higher rainbow-steelhead parr density $\left(1.8 / 100 \mathrm{~m}^{2}\right.$ or $\left.66 \%\right)$ than untreated sections. No difference was noted for chinook.

A randomized block analysis of variance was done for the present report using one treatment and control section in one stratum and two treatment and control sections from a second stratum, repeated annually from 1985 through 1988. Average densities of chinook and steelhead parr were 19\% and 46\% higher in treatment than control sections, respectively. Statistically, treatment densities were significantly higher $(p=0.03)$ for chinook but the steelhead densities did not differ $(p=0.42)$. 
Appendix table $B I \cdot c h$

LOCATION OF AFFECTED REACH:From Yoosa Cr, to Brown's Cr, in 1984 and from Yoosa Cr. to the Forest Boundary from 1985 onward.

DRAI NAGE: Cl earwater R.

SPECIES: Spring Chinook, Natural PROJECT TYPE: Instream Structures

YEAR I NITIATED: 1983.84 EXPECTED PROJECT LIFE (YRS):

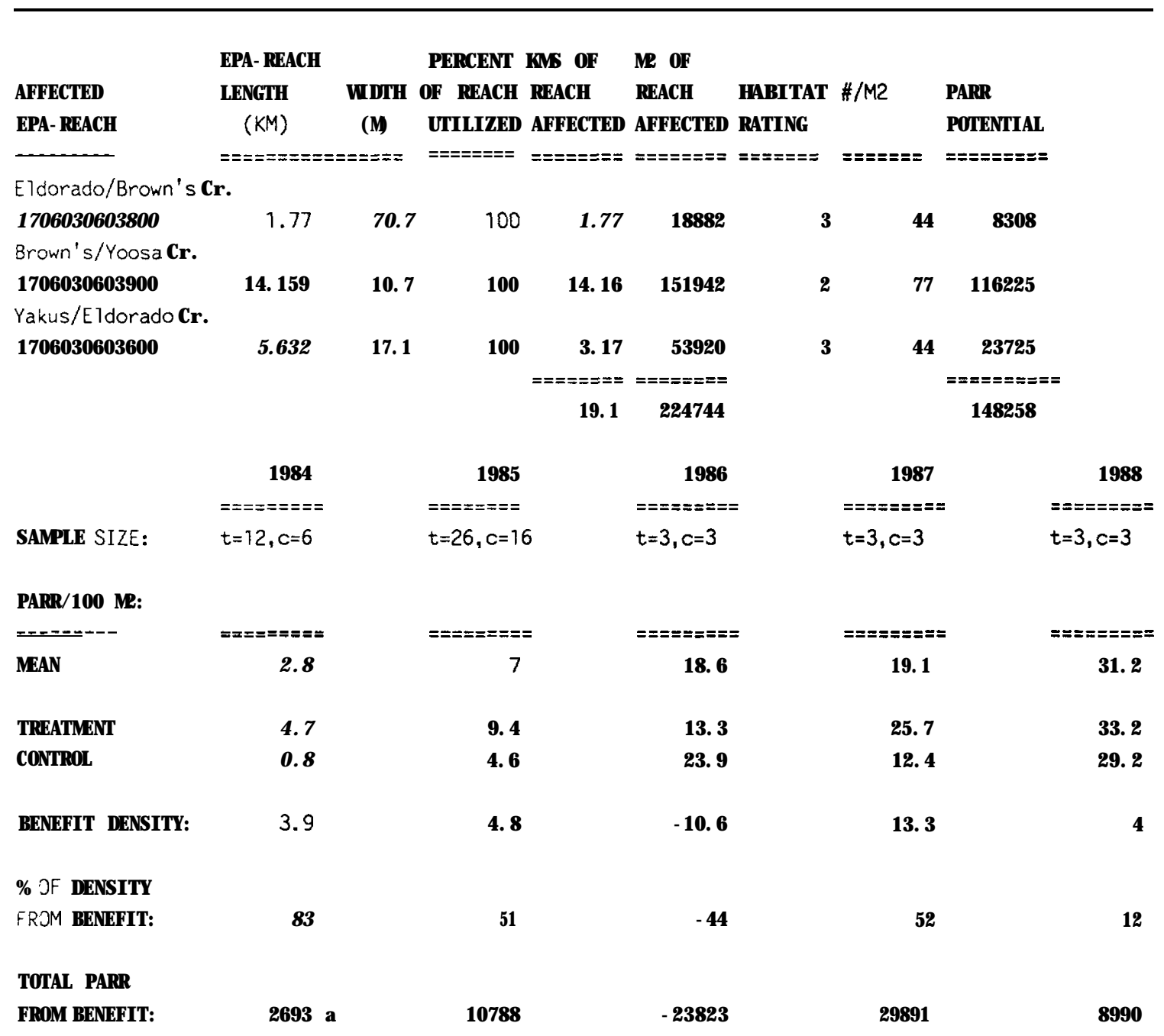

a. In 1984 only $12.87 / 14.16 \mathrm{~km}$ of the Yoosa $\mathrm{Cr}$ to Brown's $\mathrm{Cr}$ reach was treated, and an estimated $50 \%$ of this reach contained instream structures. Thus, benefits

in 1984 were applied to $151,942 \mathrm{~m} 2 \times(12.87 / 14.16) \times 0.5=69,050 \mathrm{~m} 2$ 
Appendix table $B \mid \cdot s h$

LOCATION OF AFFECTED REACH:From Yoosa Cr, to Brown's Cr. in 1984 and from Yoosa Cr. to the Forest Boundary from 1985 onward.

DRAI NAGE: Cl earwater R.

SPECIES: Sum. Steelhead, Nat, B's PROJECT TYPE: Instream Structures

YEAR INITIATED: 1983.84 EXPECTED PROJECT LIFE (YRS):

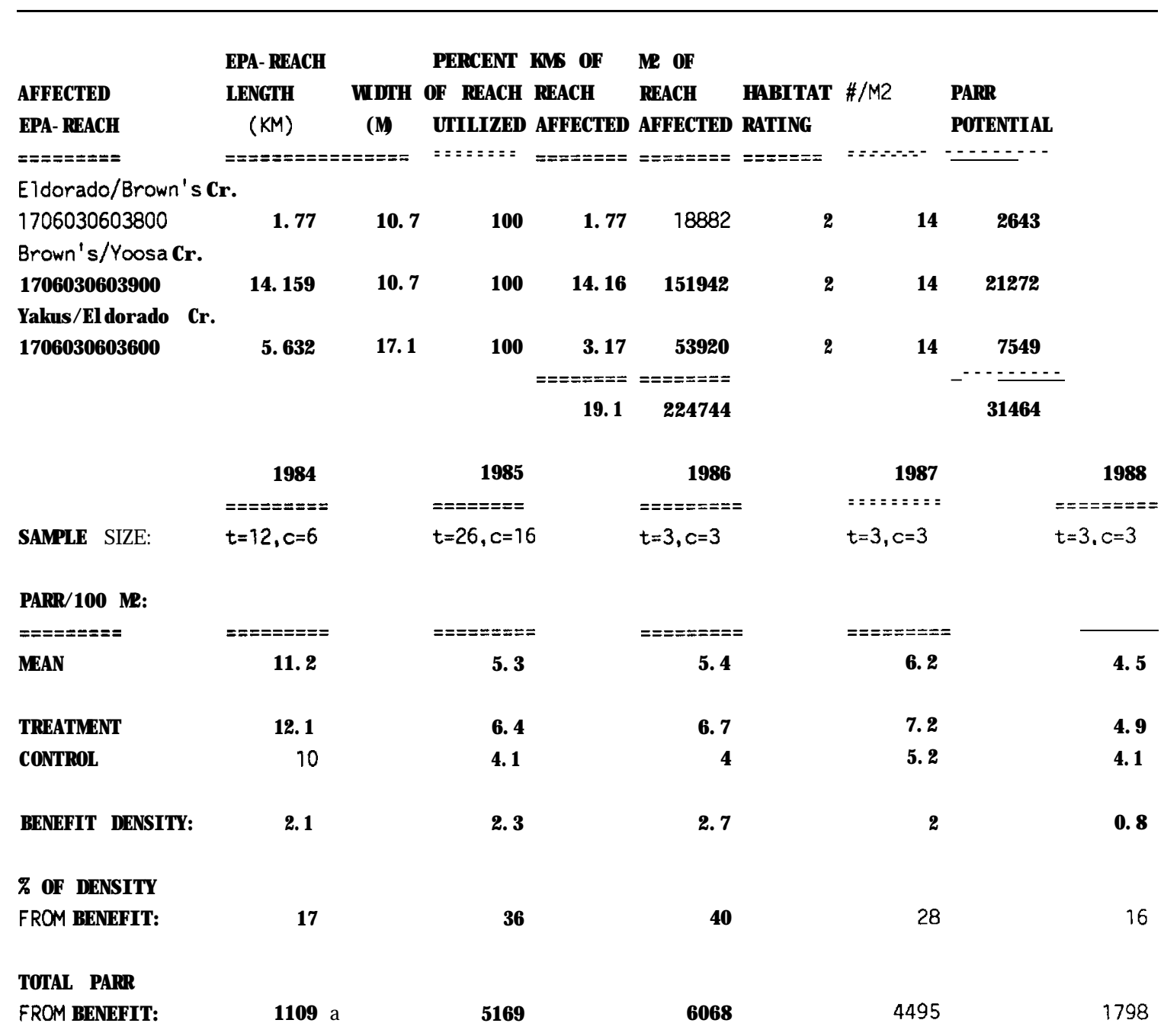

a. In 1984 only $12.87 / 14.16 \mathrm{~km}$ of the Yoosa Cr to Brown's Cr reach was treated, and

an estimated $50 \%$ of this reach contained instream structures. Thus, benefits

in 1984 were applied to $116,225 \mathrm{~m} 2 \times(12.87 / 14.16) \times 0.5=52,818 \mathrm{~m} 2$ 
Appendix B-2. Proposed definition of mitigation benefits for implemented project in Eldorado Creek.

Project Type: Passage barriers

Year Implemented: 1984-1985

Sponsor: Clearwater National Forest

\begin{tabular}{|c|c|c|}
\hline \multirow[b]{2}{*}{ Enhancement } & \multicolumn{2}{|c|}{ Species Benefited } \\
\hline & B-Run Steelhead & Spring Chinook \\
\hline Production Type: & natural & natural \\
\hline Hectares Added: & 14.3 & 14.3 \\
\hline
\end{tabular}

\section{Production Constraints: High sediment levels}

Definition of Benefits: Complete passage barriers to adults of both species were removed. Benefits will be determined from estimated numbers of parr reared above the project at 3- to S-year intervals.

Total abundance of steelhead parr above the project was estimated in August 1986 following an outplant of 1,150 Dworshak National Fish Hatchery adult steelhead in 1985. An estimated 7,310 yearling steelhead were present above the project in 1986, and additional parr were produced downstream of the project.

Total abundance of chinook parr above the project was estimated in August 1986 following an outplant of 270,000 Rapid River Hatchery chinook fry in AprilMay. August 1986 abundance totaled 30,203 (11.2\% survival). Most of the area was underseeded as evidenced by decreases in abundance away from stocking sites.

Total abundance of chinook and steelhead was estimated in 1986 using stratified sampling. Steelhead population abundance estimate for other years are the product of mean density in monitoring sites and total production area added. Chinook population abundance for 1987 and 1988 were based on 1986 estimates of fry-to-parr survival (11.2\%) multiplied by the number of fry introduced. 
Appendix table $B 2-c h$

LOCATION OF AFFECTED REACH: The entire upper Eldorado Cr, beginning at barrier removal site, one mile up from the mouth.

DRAI NAGE: Clearwater $\mathrm{R}$, Lolo $\mathrm{Cr}$ STREAM: EIdorado $\mathrm{Cr}$

SPECIES: Spring Chinook, Natural PROJECT TYPE: Barrier Removal

YEAR INITIATED: 1984.85 EXPECTED PROJECT LIFE (YRS): $50 t$

\begin{tabular}{|c|c|c|c|c|c|c|c|}
\hline & EPA. REACH & & PERCENT KMS OF & M2 OF & & & \\
\hline AFFECTED & LENGTH & WI DTH OF & DF REACH REACH & REACH & HABI TAT & $\# / M 2$ & PARR \\
\hline EPA. REACH & $(K M)$ & (M) UT & UTILIZED AFFECTED & AFFECTED & RATING & & POTENTI AL \\
\hline 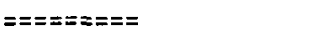 & $=====ニ==$ & Еニ=ニ=ニ = & 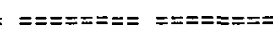 & $==ニ=\approx=ニ==$ & $==ニ=ニ===$ & $===== \pm=$ & =ニニニニニニニニ \\
\hline Entire stream length & & & & & & & \\
\hline 1706030603700 & 28.96 & 6.1 & 27.35 & 143478 & 2 & 77 & 110478 \\
\hline
\end{tabular}

\begin{tabular}{|c|c|c|c|c|c|}
\hline & 1984 & 1985 & 1986 & 1987 & 1988 \\
\hline SAMPLE SIZE: & $\begin{array}{l}=======2= \\
c=4\end{array}$ & $\begin{array}{l}======-2 \\
c=6\end{array}$ & $\begin{array}{l}====== \pm== \\
t=17\end{array}$ & $\begin{array}{l}==\approx====== \\
t=3\end{array}$ & $\begin{array}{l}======== \\
t=3\end{array}$ \\
\hline PARR/ 100 M2: & & & & & \\
\hline $\begin{array}{l}========= \\
\text { MEAN }\end{array}$ & $=\approx z====\Xi=$ & 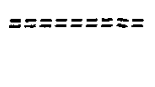 & $========0$ & $==ニ==ニ=ニ=$ & $== \pm===ニ=ニ$ \\
\hline TREAT ME NT & & & 29.9 & 58.1 & 26.9 \\
\hline CONTROL & 0 & 0 & & & \\
\hline BENEF I T DENSI TY: & & & 29.9 & 58.1 & 26.9 \\
\hline \% OF DENSI TY & & & & & \\
\hline FROM BENEFI T: & & & 100 & 100 & 700 \\
\hline TOTAL PARR & & & & & \\
\hline FROM BENEFI T: & & & 30206 a & $13328 \mathrm{~b}$ & 5936 \\
\hline
\end{tabular}

a. Population estimate derived from stratified sampling in August 1986. Sumner parr were survivors from 270,000 fry stocked in April and May 1986. Fry to parr survival was $11,2 \%$.

b. Based on numbers of fry stocked multiplied by the fry to parr survival rate estimated in 1986. 
Appendix table $82 \cdot s h$

LOCATION OF AFFECTED REACH: The entire upper Eldorado Cr, beginning at barrier removal site, one mile up from the mouth.

DRAI NAGE: $\mathrm{Cl}$ earwater $\mathrm{R}$, Lolo $\mathrm{Cr}$ STREAM: EIdorado $\mathrm{Cr}$

SPECIES: Sum. Steelhead, Nat, B's PROJECT TYPE: Barrier Removal

YEAR INITIATED: 1984.85 EXPECTED PROJECT LIFE (YRS): $50 t$

\begin{tabular}{|c|c|c|c|c|c|c|c|c|}
\hline & EPA. REACH & & PERCENT & KMS OF & M2 OF & & & \\
\hline AFFECTED & LENGTH & WI DTH & OF REACH & REACH & REACH & HABI TAT & \multirow[t]{2}{*}{$\# / M 2$} & PARR \\
\hline EPA- REACH & $(K M)$ & ( M) & UTI LI ZED & AFFECTED & AFFECTED & RATING & & POTENTI AL \\
\hline$==ニ=ニ=ニ=ニ$ & 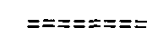 & \multirow{2}{*}{\multicolumn{5}{|c|}{ 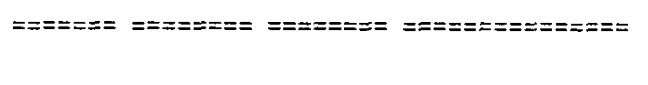 }} & \multirow[t]{2}{*}{$======\approx$} & \multirow[t]{2}{*}{ 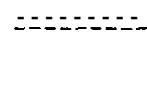 } \\
\hline Entire stream length & & & & & & & & \\
\hline 1706030603700 & 28.96 & 6.1 & 86 & 27.35 & 143478 & 3 & 10 & 14348 \\
\hline
\end{tabular}

\begin{tabular}{|c|c|c|c|c|c|}
\hline & 1984 & 1985 & 1986 & 1987 & 1988 \\
\hline & 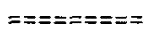 & 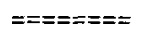 & 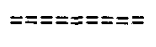 & 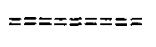 & $==ニ=ニ=ニ=ニ$ \\
\hline SAMPLE SIZE: & $c=4$ & $c=6$ & $t=17$ & $t=3$ & $t=3$ \\
\hline
\end{tabular}

PARR/IOO M2:

$===x===x$

ME AN

$===\mathbf{=}=\mathbf{=}=$

$====$ = $=$ =

$==$ = $=$ = $=$

$== \pm=== \pm==$

TREATME NT

CONTROL

0

3.9

3.7

0.91

BENEFI T DENSI TY:
3,9

100

7310

5309 b

3,7
0,91

\% OF DENSITY

FROM BENEFI T:

TOTAL PARR

FROM BENEFI T :

$100 \quad 100$ a. Population estimate derived from stratified sampling in August 1986.

b. Based on parr density x surface area/100. 
Appendix B-3. Proposed definition of mitigation benefits for implemented projects on the upper Lochsa River.

Project Type: Instream structures (lower White Sand and Crooked Fork Creeks) year Implemented: 1983-1984

Sponsor: Clearwater National Forest

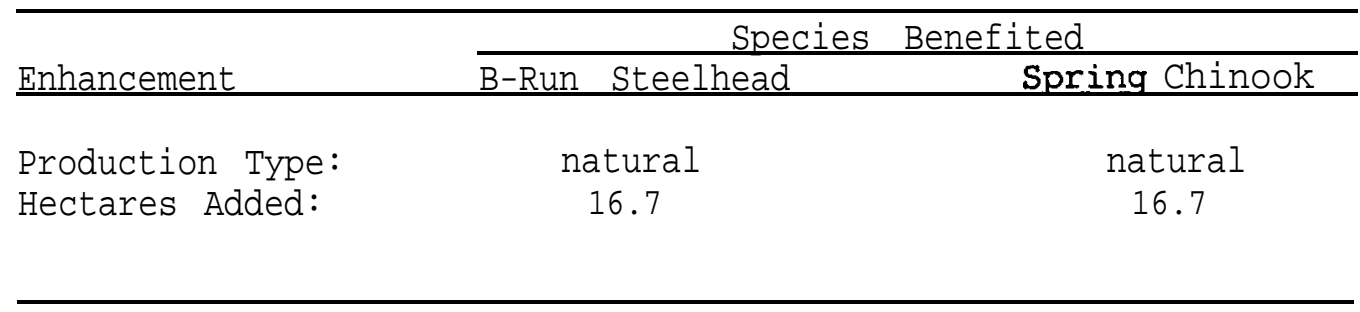

\section{Production Constraints:}

Definition of Benefits: An evaluation was conducted in 1984 at low parr abundance for both species. Little habitat change was observed, and no difference in densities for either species was detected between treated and untreated sections. A high rate of structure failure occurred the first year after implementation. No definable benefits are anticipated from this project.

The deflector logs, which angle downstream from their attachment points on shore, modify but a small portion of the stream width. After the first two to three years, some were destroyed by ice and high water, others were stranded mostly above water and all had lost their needles and most branches.

Based on Kramer and Espinosa (1985), the 198 live trees and 63 "existing debris" which were established by this project would create $1,415 \mathrm{~m}^{2}$ of pool habitat. If all this habitat became excellent for parr rearing, then 108/100 $\mathrm{m}^{2} \star 1415 / 100$ or 1528 chinook parr and $20 / 100 \mathrm{~m}^{2} \star 1415 / 100$ or 283 steelhead parr could be reared annually in the enhanced area. 
Appendix table B3-ch

LOCATION OF AFFECTED REACH: Upper Lochsa River forks: 15.6 miles of Crooked Fork Creek and 3.4 miles of lower White Sand Creek.

DRAI NAGE: Clearwater R, Lochsa R STREAM: Crooked Fk and White Sand creeks

SPECIES: Spring Chinook. Natural PROJECT TYPE: Instream Structures

YEAR I NITIATED: 1983 EXPECTED PROJECT LIFE (YRS):

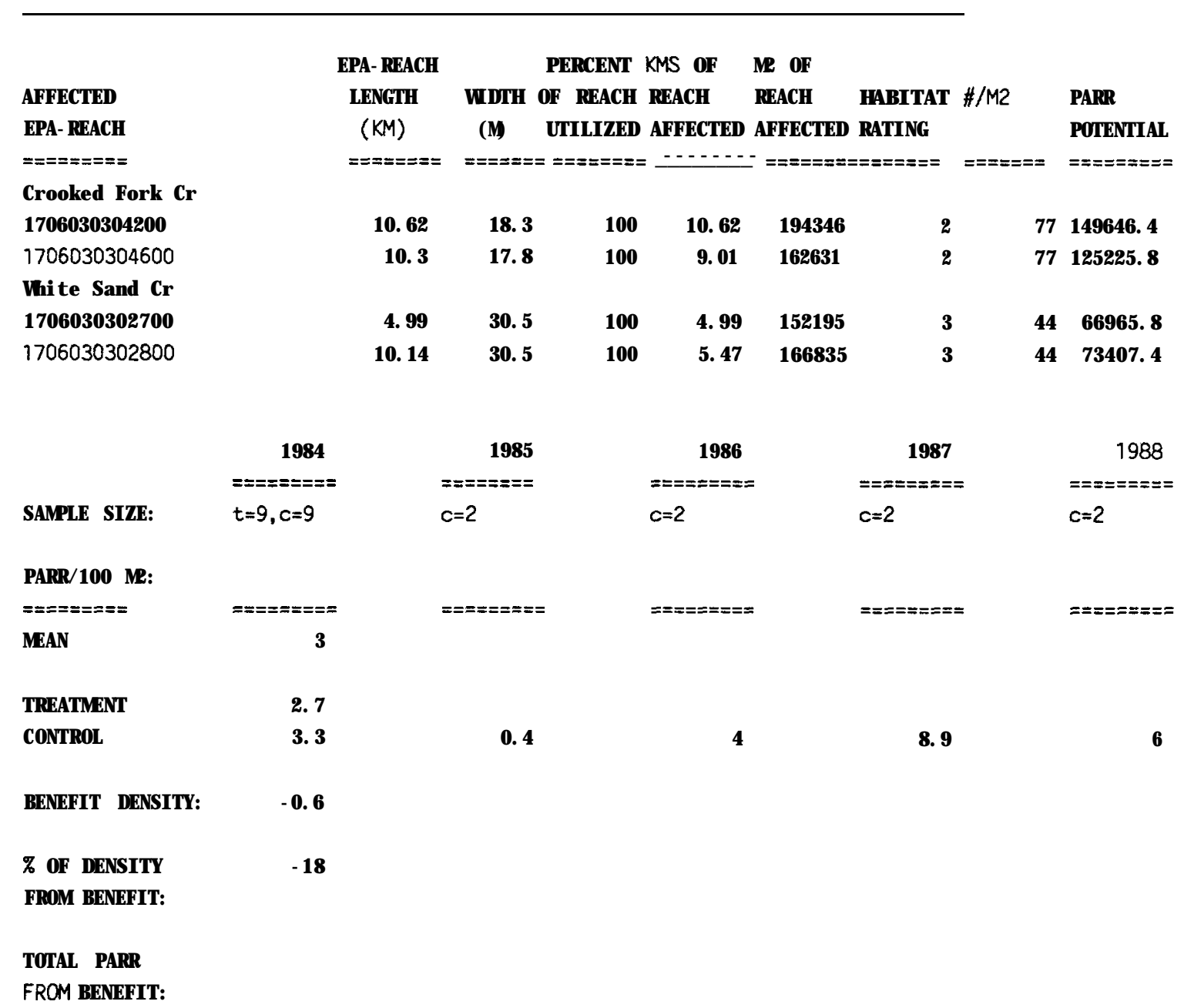


Appendix table B3-sh

LOCATION OF AFFECTED REACH : Upper Lochsa River forks: 15.6 miles of Crooked Fork Creek and 3.4 miles of lower White sand creek.

DRAI NAGE: Clearwater $R$, Lochsa $R$ STREAM: Crooked Fk and White Sand creeks

SPECIES: Sum. Steelhead, Nat B's PROJECT TYPE: Instream Structures

YEAR INITIATED: 1983 EXPECTED PROJECT LIFE (YRS):

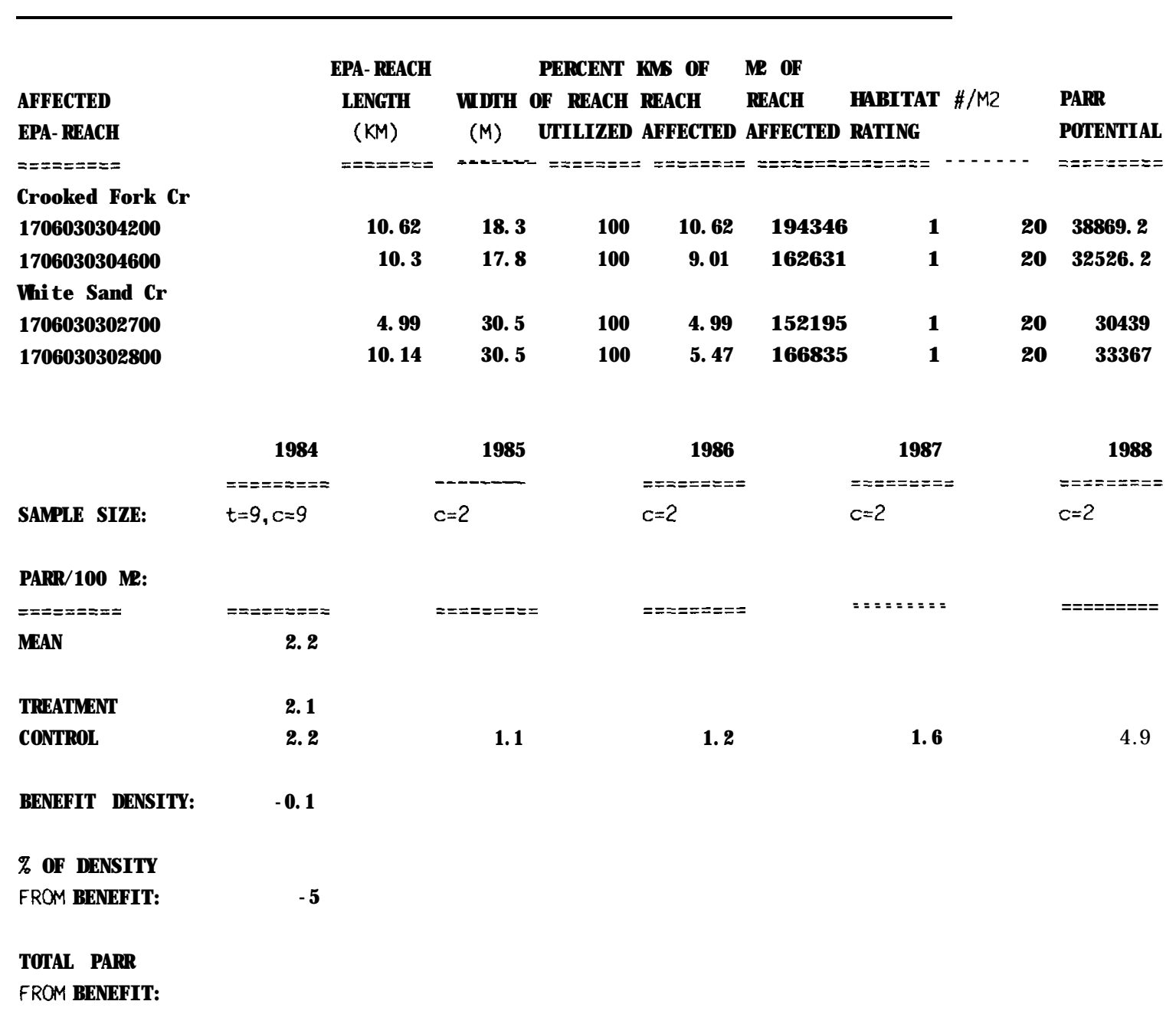


Appendix B-4. Proposed definition of mitigation benefits for implemented projects on Crooked Fork Creek.

Project Type: Passage barriers

Year Implemented: $1984-1985$

Sponsor: Clearwater National Forest

\begin{tabular}{|c|c|c|}
\hline \multirow[b]{2}{*}{ Enhancement } & \multicolumn{2}{|c|}{ Species Benefited } \\
\hline & B-Run Steelhead & Spring Chinook \\
\hline $\begin{array}{l}\text { Production Type: } \\
\text { Hectares Added: }\end{array}$ & $\begin{array}{c}\text { natural } \\
10.7\end{array}$ & $\begin{array}{c}\text { natural } \\
10.5\end{array}$ \\
\hline
\end{tabular}

\section{Production Constraints:}

Definition of Benefits: Passage barriers to adults of both species were removed. Benefits will be determined from estimated numbers of parr reared above the project at 3-to 5-year intervals.

As of 1988, steelhead fry had not been allocated for introductions into upper Crooked Fork Creek. An estimated 500 rainbow-steelhead parr reared above the project in 1986.

Total abundance of chinook parr above the project was estimated in August of 1986, 1987, and 1988 following May fry plants of 156,200, 164,400, and 102,800, respectively. Estimated parr abundance was 17,600, 32,600, and 17,700, respectively. Average survival rate for the three years was $16.1 \%$, and ranged from 11.3 to $19.8 \%$. Most of the area was underseeded in both years as evidenced by decreases in abundance away from stocking sites.

The barrier had been a complete block to adult chinook passage and a partial block to steelhead. We assumed 90\% of adult steelhead were blocked based on occasional observations of steelhead parr above and prior to the project (Al Espinosa, personal communication). Hence, steelhead parr abundance was multiplied by 0.90 to estimate project benefits.

No steelhead supplementation has occurred above the project. Pioneering by wild/natural adults will be the source of population rebuilding. 
Appendix table B4-ch

LOCATION OF AFFECTED REACH: From Barrier removal project, $1.21 \mathrm{~km}$ above mouth of Boulder $\mathrm{Cr}$ up to headwaters of crooked $F$ k and Hopeful creeks.

DRAI NAGE: Cl earwater $R$, Lochsa $R$ STREAM: Crooked $\mathrm{Fk} \mathrm{Cr}$

SPECIES: Spring Chinook, Natural PROJECT TYPE: Barrier Removal

YEAR INITIATED: 1984.85 EXPECTED PROJECT LIFE (YRS):

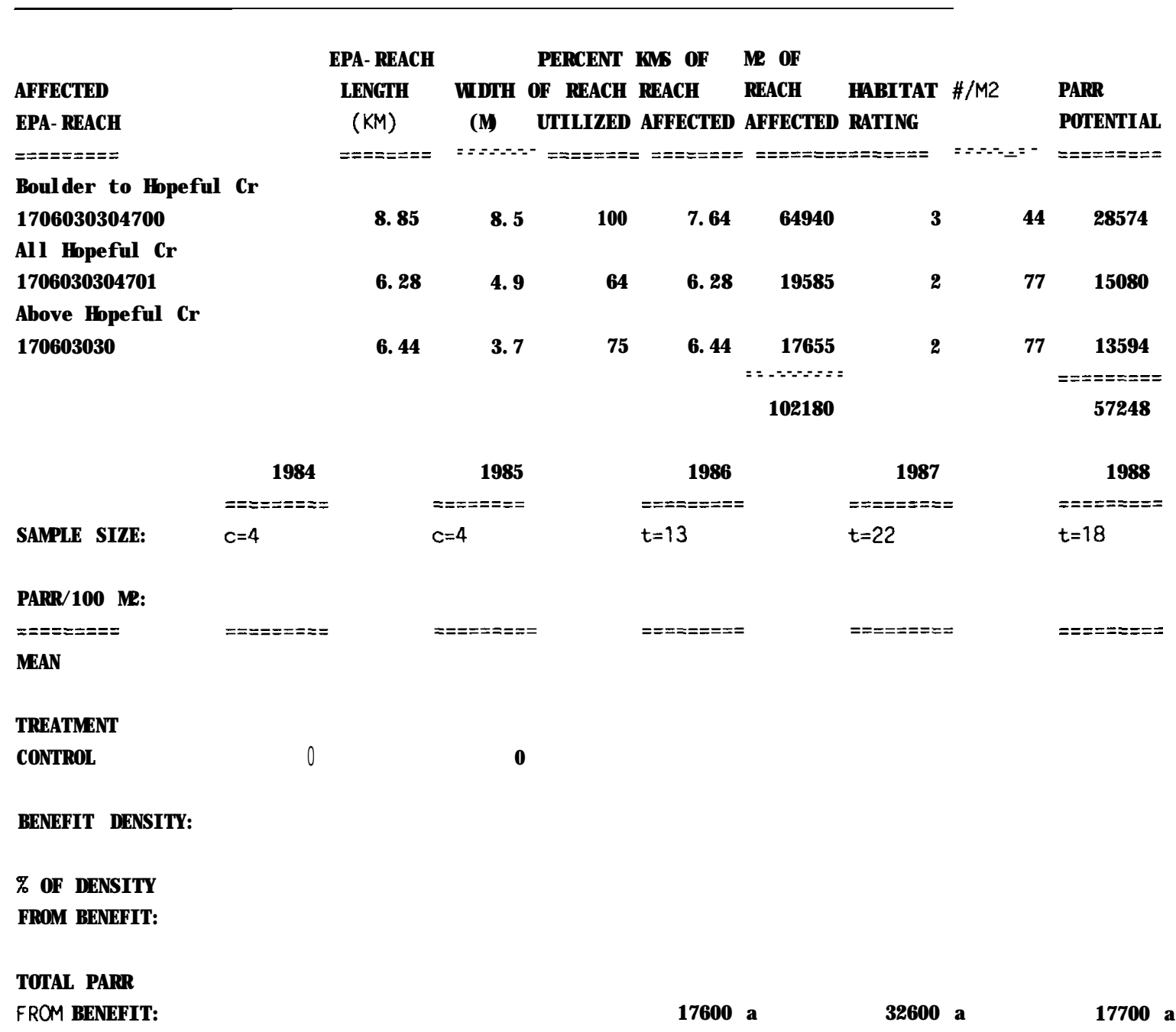

a. Parr numbers estimated by stratified sampling in 1986, 1987 and 1988 
Appendix table B4-sh

LOCATION OF AFFECTED REACH: From Barrier removal project, $1.21 \mathrm{~km}$ above mouth of Boulder $\mathrm{Cr}$ up to headwaters of crooked $F k$ and Hopeful creeks.

DRAI NAGE: Clearwater $R$, Lochsa $R$ STREAM: Crooked $\mathrm{Fk} \mathrm{Cr}$

SPECIES: Sum. Steelhead. Nat, B's PROJECT TYPE: Barrier Removal

YEAR INITIATED: 1984.85 EXPECTED PROJECT LIFE (YRS):

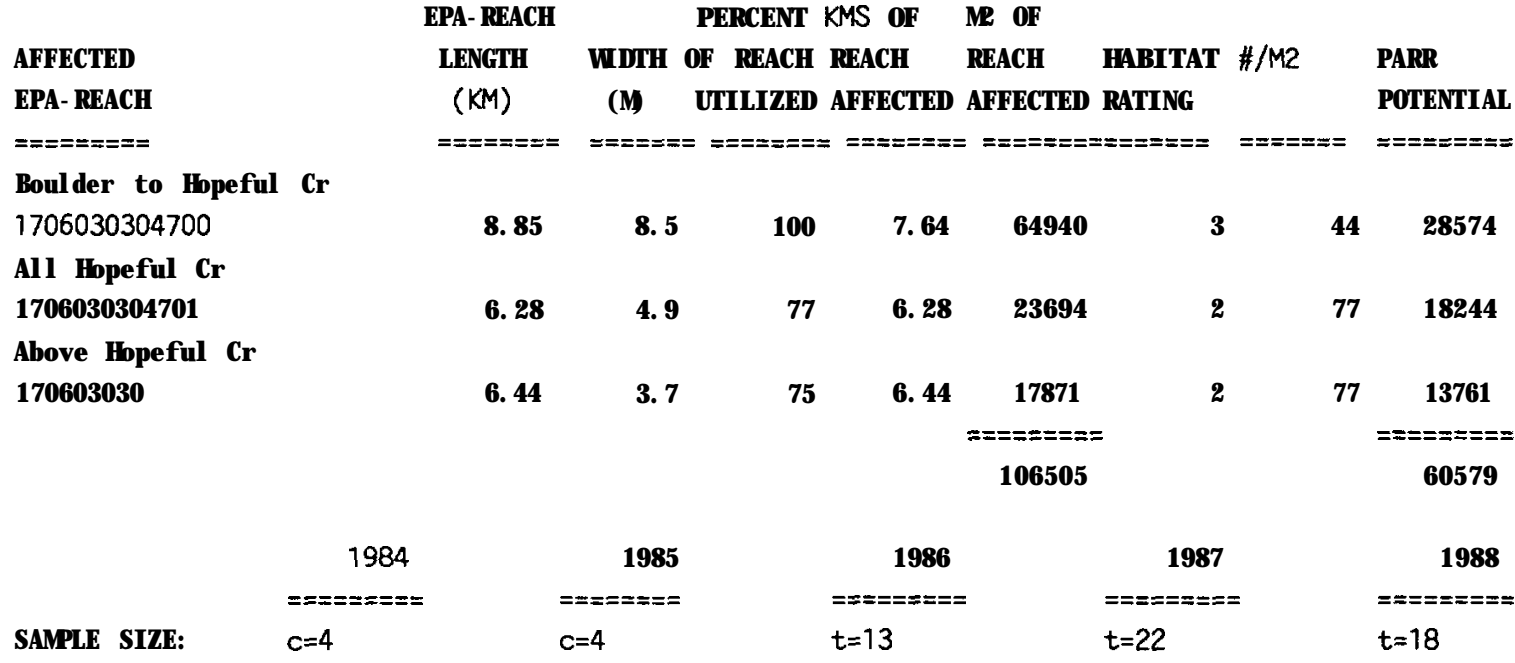

PARR/ 100 M2:

$== \pm== \pm===$

$==:==x= \pm=$

$=========$

$==\because=====8$

$== \pm=x= \pm=x$

$==\geq== \pm= \pm=$

ME AN

TREATMENT

CONTROL

0.03

0.29

0.09

0

BENEFI T DENSI TY:

$0.26 a$

0.08 a

\% OF DENSI TY

FROM BENEFI T:

TOTAL PARR

FROM BENEF I T:

a. Assumes $90 \%$ of steel head were blocked prior to barrier removal, thus only $90 \%$ of parr density is a benefit. 
Appendix B-5. Proposed definition of mitigation benefits for implemented project on colt Creek.

Project Type: Passage barriers

Year Implemented: $\quad 1986$

Sponsor: Clearwater National Forest

\begin{tabular}{lcc}
\hline & \multicolumn{2}{c}{ Species } \\
\cline { 2 - 3 } Enhancement & B-Run Steelhead & Spring Chinook \\
\hline Production Type: & natural & natural \\
Hectares Added: & 6.1 & 0 \\
\hline
\end{tabular}

Production Constraints: Gradient judged too steep to achieve chinook passage.

Definition of Benefits: Passage barriers to adult steelhead were removed. Benefits will be determined from estimated numbers of steelhead parr reared above the barriers at 3- to 5-year intervals (after introductions begin). Parr abundance will be factored by parr-to-smolt survival rates.

As of 1988, steelhead fry have not been allocated for introductions into colt Creek. No rainbow-steelhead parr were observed in the monitoring section in 1987 or 1988 . 
Appendix table B5-sh

LOCATION OF AFFECTED REACH: Upper Colt Creek, beginning at the barrier removal project, $1 / 2$ mile bove mouth.

DRAINAGE: Clearwater $R$, Lochsa $R$, STREAM: Colt $\mathrm{Cr}$

White $\mathrm{Sand} \mathrm{Cr}$

SPECIES: Sum. Steelhead, Nat. B's PROJECT TYPE: Barrier Removal

$\begin{array}{llll}\text { YEAR INITIATED: } & 1986 & \text { EXPECTED PROJECT LIFE (YRS): }\end{array}$

\begin{tabular}{|c|c|c|c|c|c|c|c|c|}
\hline & EPA. REACH & & PERCENT & KMS OF & M2 OF & & & \\
\hline AFFECTED & LENGTH & WI DTH & OF REACH & REACH & REACH & HABI TAT & $\# / M 2$ & PARR \\
\hline EPA-REACH & $(X M)$ & ( M) & UTI LI ZED & AFFECTED & AFFECTED & RATI NG & & POTENTI AL \\
\hline$==== \pm== \pm= \pm$ & ייניינייניוי & יינייני & 1 $=======$ & $z== \pm==x=$ & $==$ ======= & $==s=== \pm=$ & : : : : : : : & : : : : : : : : \\
\hline 1706030303800 & 20.92 & & 100 & 20,11 & 61303 & 2 & 14 & 8582 \\
\hline
\end{tabular}

1984

$:::::::::$

SAMPLE SIZE:

PARR/ 100 M2:

$==== \pm== \pm=$

MEAN

TREATMENT

CONTROL

1985

$\therefore:::::$

1986

: : : : : : : : :

1987

$==x= \pm=x=$

$c=1$

: : : : : : :

$t=1$

$===== \pm==0$

$=========$

===е==е=="

$==x= \pm==+=$
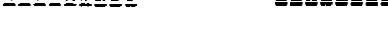

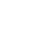


Appendix B.6a. Proposed definition of mitigation benefits for implemented projects on Crooked River.

Project Type: Passage barrier (culvert)

Year Implemented: $\quad 1984$

Sponsor: Nez Perce National Forest

\begin{tabular}{|c|c|c|}
\hline \multirow[b]{2}{*}{ Enhancement } & \multicolumn{2}{|c|}{ Species Benefited } \\
\hline & B-Run Steelhead & Spring Chinook \\
\hline Production Type: & natural & natural \\
\hline Hectares Added: & 12.7 & 8.4 \\
\hline
\end{tabular}

Production Constraints: Channelized (treated with structures in 1985), lack of riparian vegetation for $6.1 \mathrm{~km}$ upstream of barrier culvert.

Definition of Benefits: A partial barrier to adult steelhead and chinook was removed by replacement of a culvert with a bridge. Benefits will be determined annually from estimated numbers of parr reared above the project. Fifty percent of this production is assumed to be the mitigation benefit.

Total abundance of steelhead parr between the project and the confluence of the East Fork and West Fork was 2,750 in 1986 and 2,347 in 1987. Total abundance of chinook parr for these two years were 7,413 and 1,438 , respectively. Total abundance estimates in 1988 (3,915 steelhead and 14,122 chinook) additionally included the two forks. 
Appendix table $B 6 a-c h$

LOCATION OF AFFECTED REACH: Beginning $13.0 \mathrm{~km}$ above the mouth $(1.0 \mathrm{~km}$ above the mouth of Relief Cr. and continued to the confluence of the east and west forks in 1986 and 1987 and included these two forks in 1988.

DRAI NAGE: Cl earwater R STREAM: Crooked R

SPECIES: Spring Chinook, Natural PROJECT TYPE: Barrier (partial) Removal

YEAR INITIATED: 1984 EXPECTED PROJECT LIFE (YRS):

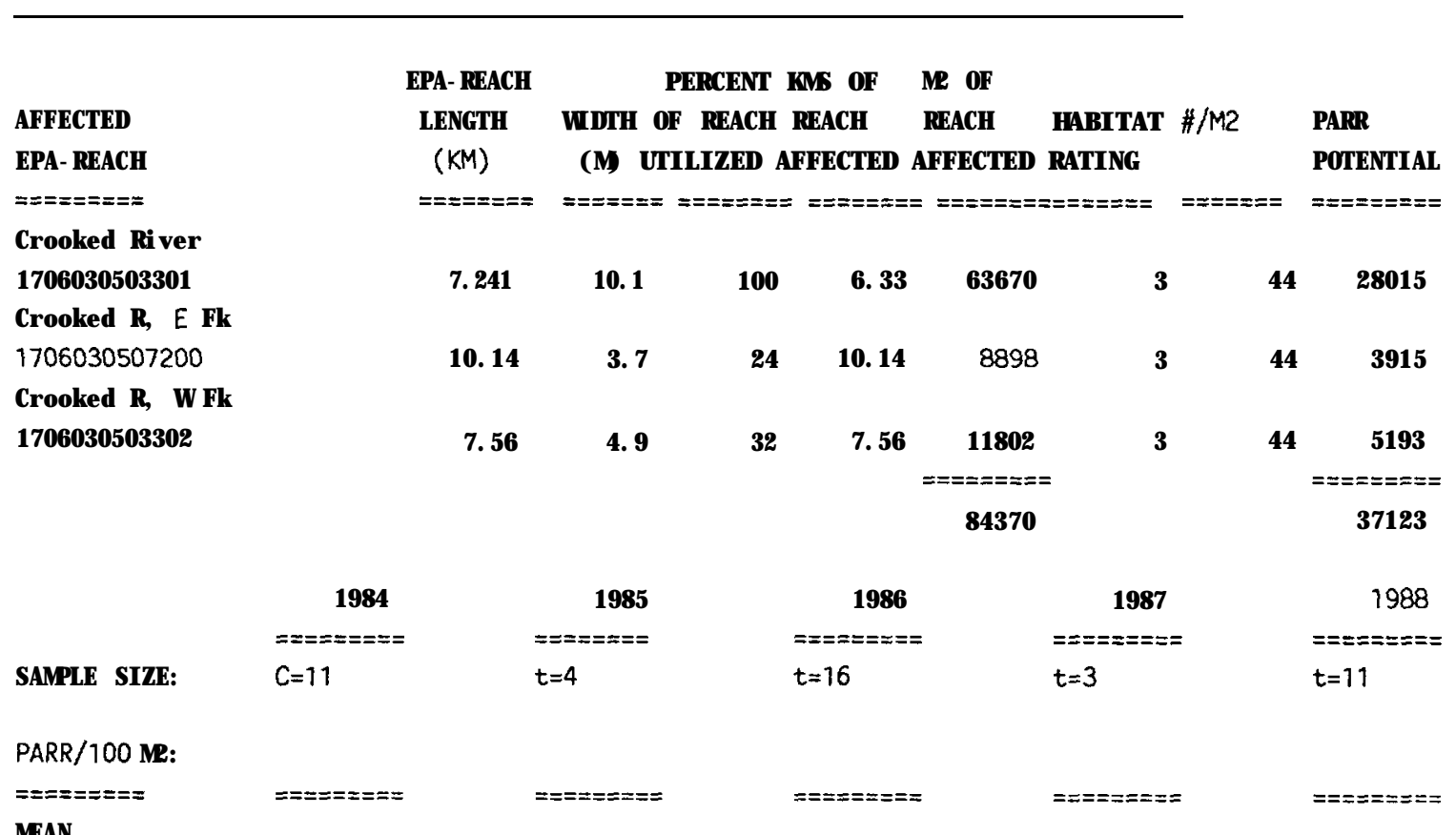

ME AN

TRE AT ME NT

16.82

CONTROL

0.23

BENEFI T DENSI TY:

\% OF DENSI TY

FROM BENEFIT:

TOTAL PARR

FROM BENEFIT:

PRE-TREAT, No's:

146

a. Estimate is (surface area/100*average density) times $50 \%$ as the barrier benefit.

b. Estimates are $50 \%$ of that obtained from stratified sampling, assuming barrier removal benifit from barrier removal is $50 \%$ of adult passage. 
Appendix table B6a-sh

LOCATION OF AFFECTED REACH: Beginning $13.0 \mathrm{~km}$ above the mouth $(1.0 \mathrm{~km}$ above the mouth of Relief Cr.) and continued to the confluence of the east and west forks in 1986 and 1987 and included these two forks in 1988.

DRAI NAGE: Cl ear water R STREAM: Crooked R

SPECIES: Sum. Steelhead, Nat, B's PROJECT TYPE: Barrier (partial) Removal

YEAR INITIATED: 1984 EXPECTED PROJECT LIFE (YRS):

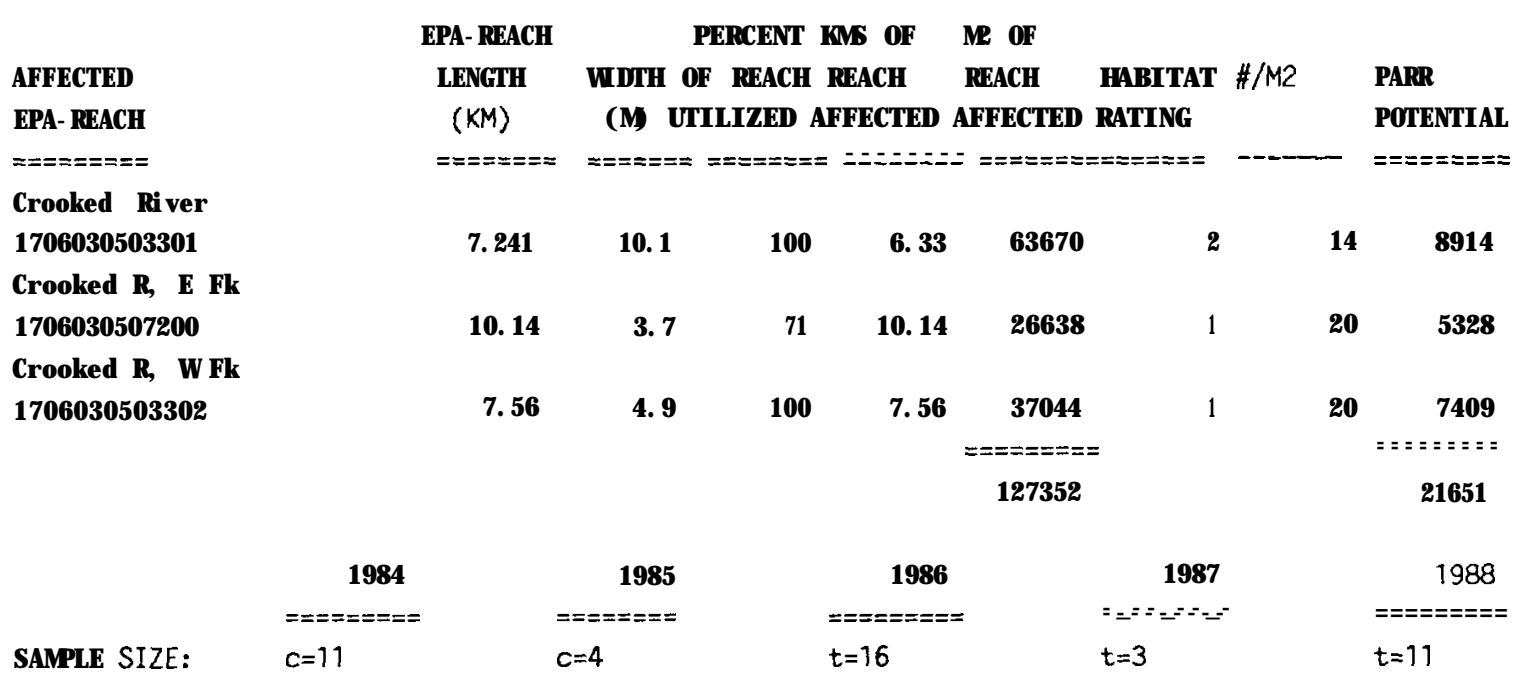

PARR/100 M2:

$==$ =ニะ= =

=ニニニニニ=ニ=

Iニニニニニニ=ニ

=ニニニニニ = =

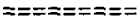

$=z==:===x=$

ME AN

TRE AT ME NT

CONTROL

0.28

0.97

BENEFI T DENSI TY:

\% OF DENSITY

FROM BENEFI T :

TOTAL PARR

FROM BENEFI T:

1375 b

1174 b

1958 b

PRE-TREAT, NO'S:

178

618

b. Estimates are $50 \%$ of that obtained from stratified sampling, assuming barrier removal benifit

from barrier removal is $50 \%$ of adult passage. 
Appendix B-6b. (Crooked R., continued).

Project Type: Instream structures, riparian revegetation

Year Implemented: $\quad 1984 \cdot 1985$

Sponsor: Nez Perce National Forest

\begin{tabular}{|c|c|c|}
\hline \multirow[b]{2}{*}{ Enhancement } & \multicolumn{2}{|c|}{ Species Benefited } \\
\hline & B-Run Steelhead & Spring Chinook \\
\hline $\begin{array}{l}\text { Production Type: } \\
\text { Hectares Enhanced: }\end{array}$ & natural & natural \\
\hline & & \\
\hline
\end{tabular}

Production Constraints: Channelized, lack of riparian vegetation.

Definition of Benefits: Statistical comparisons of steelhead and chinook parr densities in treated and untreated sections will be done at 3- to S-year intervals to determine the differences in densities.

An evaluation was conducted in July and August 1986 at a fully seeded condition for yearling steelhead, and moderate seeding levels for chinook. Alteration of habitat by the structures had occurred; riparian conditions had not yet improved. No difference in densities could be attributed to the instream structure project.

A randomized block analysis of variance was done for the present report using one treatment and one control section in each of two strata, repeated annually from 1985 through 1988 to compare parr densities for both chinook and steelhead. Average densities of chinook and steelhead parr were 3.8\% and 42.1\% higher, respectively, in treatment than control sections. Statistically, the comparisons of treatment and control densities were not significant for either species $(p=0.97$ and $p=0.44$, respectively). 
Appendix table $86 b-c h$

LOCATI ON OF AFFECTED REACH: Beginning 14.1 km upstream from the mouth, at the culvert removal site and continuing upstream $7.24 \mathrm{kms}$.

DRAINAGE: Clearwater $R$

STREAM: crooked R

SPECIES: Spring Chinook, Natural PROJECT TYPE: Instream Structures

YEAR INITIATED: 1984.85 EXPECTED PROJECT LIFE (YRS):

AFFECTED

EPA. REACH

$==== \pm===$

1706030503301

1706030503300
EPA- REACH PERCENT KMS OF M2 OF

LENGTH WI DTH OF REACH REACH REACH

(KM) (M) UTILIZED AFFECTED AFFECTED RATING POTENTIAL

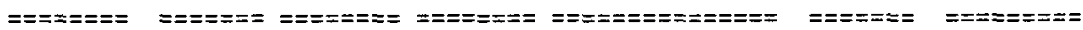

$\begin{array}{llllllll}7.241 & 10.1 & 100 & 2.735 & 26627 & 3 & 44 & 11715.88\end{array}$

12.55

$10.1 \quad 100$

4.505

45501

2

$77 \quad 35035.77$

=ニニニ=ニ=ニ

46751,65
1986

$==ニ=ニ==$

$t=2, c=2$

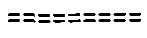

46

42,1

49.9

$\cdot 7,1$

$\cdot 17$

.5121

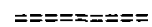

$t=2, c=2$

ニニニニニニーニニ

20.4

19.8

21

$\cdot 1,2$

.6
1987

83

3,5

0.6

2.9

9,5

\% OF DENSITY

TOTAL PARR

FROM BENEFI T:
.886

2092

6852 
Appendix table B6b-sh

LOCATI ON OF AFFECTED REACH: Beginning $14.1 \mathrm{~km}$ upstream from the mouth, at the culvert removal site and continuing upstream $7,24 \mathrm{kms}$.

DRAINAGE: Clearwater $R$

STREAM: Crooked R

SPECIES: Sum. Steelhead, Nat, B's PROJECT TYPE: Instream Structures

YEAR INITIATED: 1984435 EXPECTED PROJECT LIFE (YRS):

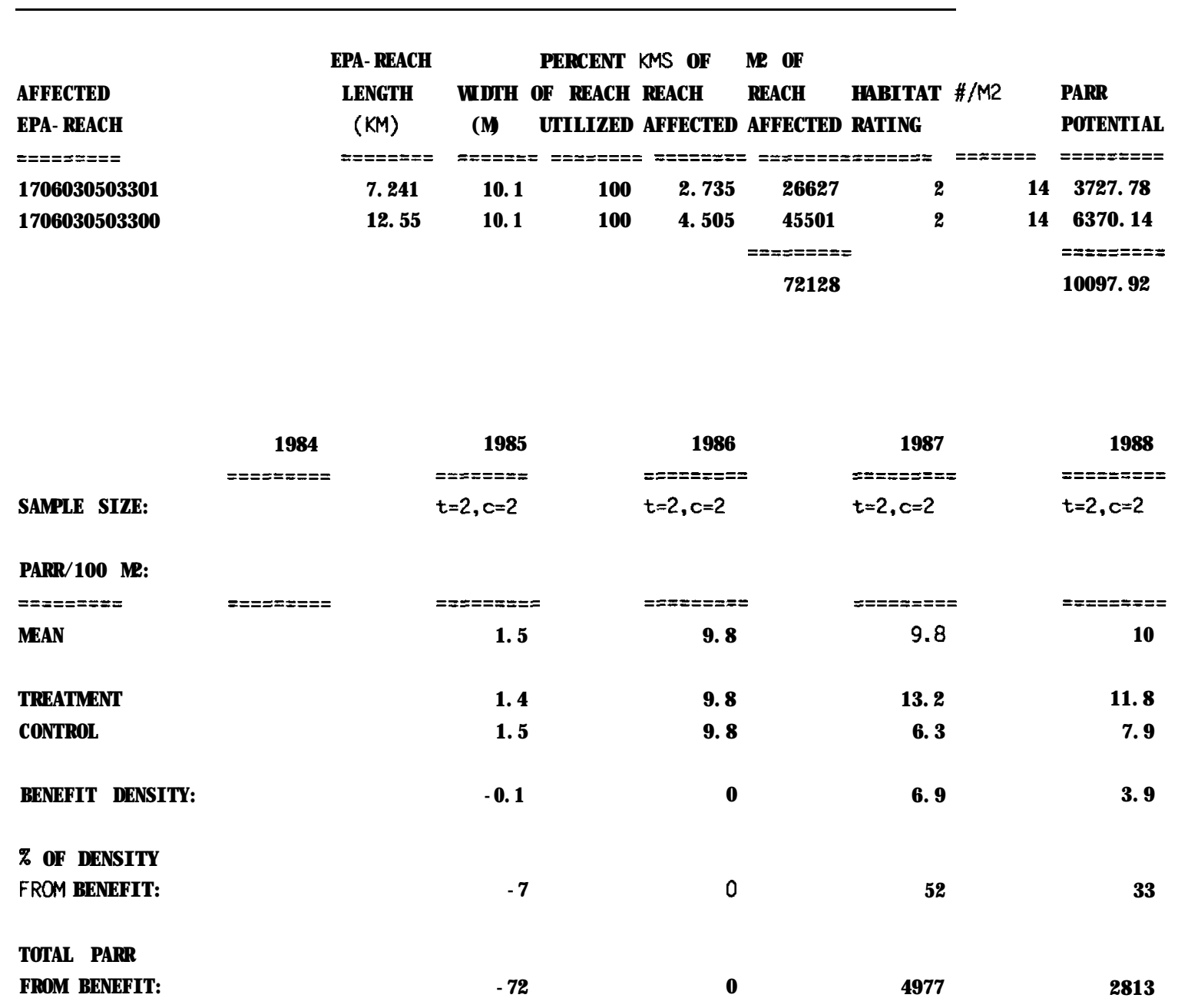


Appendix B-6c. (Crooked R., Continued).

Project Type: Off-channel developments

Year Implemented: 1984.1987

Sponsor: Nez Perce National Forest

\begin{tabular}{|c|c|c|}
\hline \multirow[b]{2}{*}{ Enhancement } & \multicolumn{2}{|c|}{ Species Benefited } \\
\hline & B-Run Steelhead & Spring Chinook \\
\hline $\begin{array}{l}\text { Production Type: } \\
\text { Hectares Added: }\end{array}$ & $\begin{array}{c}\text { natural } \\
0.65\end{array}$ & $\begin{array}{c}\text { natural } \\
0.65\end{array}$ \\
\hline
\end{tabular}

benefit chinook.

Definition of Benefits: The total abundance of steelhead and chinook parr in connected ponds and side channels will be considered mitigation benefits.

An evaluation of off-channel rearing densities was conducted in 1986. The 0.8 hectares added to Crooked River through 1985 reared an estimated 69 rainbowsteelhead parr $\left(8 / 100 \mathrm{~m}^{2}\right)$ and 739 chinook parr $\left(88 / 100 \mathrm{~m}^{2}\right)$. 
Appendix table $B 6 c-c h$

LOCATI ON OF AFFECTED REACH: Ponds connnected to Crooked River in study Strata I and II.

DRAINAGE: Clearwater $R$

STREAM: Crooked R

SPECIES: Spring Chinook, Natural PROJECT TYPE: Off-Channel Developments (Connected Ponds)

YEAR INITIATED: 1984.85 EXPECTED PROJECT LIFE (YRS):

\begin{tabular}{|c|c|c|c|c|c|c|c|c|c|}
\hline & EPA- REACH & & & RCE NT & KMS OF & M2 OF & & & \\
\hline AFFECTED & LENGTH & WI DTH & $O F$ & REACH & REACH & REACH & HABI TAT & $\# / M 2$ & PARR \\
\hline EPA. REACH & $(K M)$ & $(M)$ & & II LI ZED & AFFECTED & AFFECTED & RATI NG & & POTENTI AL \\
\hline$== \pm=== \pm==$ & $=====\Xi= \pm$ & $\Rightarrow====$ & $==:$ & $\because \cdots=$ & $\therefore===5==m$ & $========$ & $==ニ=== \pm=$ & 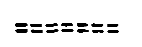 & $==ニ=ニ=ニ==$ \\
\hline 1706030503301 & & & & & & 6517 & 1 & 108 & 7038.36 \\
\hline
\end{tabular}

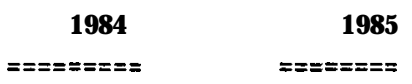

SAMPLE SIZE:

PARR/100 M2:

$== \pm==ニ==$

MEAN

TREATMENT

CONTROL

BENEFI T DENSI TY:

\% OF DENSITY

FROM BENEFI T:

TOTAL PARR

FROM BE NEFI T:

$\begin{aligned} & 1986 \\ &=\approx======= \\ & t=5\end{aligned}$

$=$ =ニニニニュニ

63.2

63.2

100

4119
1987

=ニニ=ニン = $=$

$t=1$

z=ニニ= = $=$ =

3.2

3.2

90

100

209

1988

=ニニニニニニニ

$t=2$

90.9

100

5865 
Appendix table $86 c-s h$

LOCATION OF AFFECTED REACH: Ponds connnacted to Crooked River in study Strata I and II.

DRAINAGE:Clearwater $R$

SPECIES: Sum. Steel head, Nat B's
STREAM: Crooked R

PROJECT TYPE: Off-Channel Developments (Connected Ponds)

YEAR I NI TI ATED: 1984-85

EXPECTED PROJECT LIFE (YRS):

$50+$

\section{AFFECTED}

EPA. REACH

$===\mathbf{=}==\mathbf{=}$

1706030503301

\begin{tabular}{|c|c|c|c|c|c|c|c|}
\hline EPA- REACH & & PERCENT & MMS OF & M2 OF & & & \\
\hline LENGTH & WI DTH & REACH & REACH & REACH & HABI TAT & $\# / M 2$ & PARR \\
\hline$(\mathrm{KM})$ & ( M) & UTI L I ZED & AFFECTED & AFFECTED & RATING & & POTENTI AL \\
\hline \multirow[t]{2}{*}{$====ニ==ニ$} & $=====$ & $==\quad=== \pm== \pm=$ & $:======z=$ & $===z== \pm=$ & $== \pm===\approx$ & $==ニ====$ & : : : : : : : : : \\
\hline & & & & 6517 & 2 & 14 & 912.38 \\
\hline
\end{tabular}

1984

$== \pm=ニ=ニ=$

SAMPLE SIZE:

PARR/100 M2:

$=$ =ニニニニ=ニ

ME AN

TRE AT ME NT

CONTROL

BENEFI T DENSI TY:

Z OF DENSITY

FROM BENEFI T:

TOTAL PARR

FROM BENEFI T:

1985
$====$

$==$ =ニ=ー $=$ =

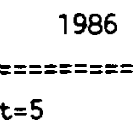

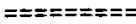

5

5

100

326
$====$

$t=1$

=ニニニニニニニニ

47,2

47.2

17

100

100

3076

1108 
Appendix B-7a. Proposed definition of mitigation benefits for implemented projects in Red River.

\section{Project Type: Instream structures}

Year Implemented: $\quad 1984 \cdot 1985$

Sponsor: Nez Perce National Forest

\begin{tabular}{|c|c|c|}
\hline \multirow[b]{2}{*}{ Enhancement } & \multicolumn{2}{|c|}{ Species Benefited } \\
\hline & B-Run Steelhead & Spring Chinook \\
\hline Production Type: & natural & natural \\
\hline Hectares Enhanced: & 11.8 & 11.8 \\
\hline
\end{tabular}

Definition of Benefits: Statistical comparisons of steelhead and chinook parr densities in treated and untreated sections will be done at 3-to 5-year intervals to determine the difference in densities.

An evaluation was conducted in July and August 1986 at moderately low steelhead and chinook parr abundance. No difference in densities could be attributed to the instream structure project.

A randomized block analysis of variance was done for the present report using one treatment and one control section in each of two strata, repeated annually from 1985 through 1988 to compare parr densities for both chinook and steelhead in treatment and control sections. Average densities of chinook parr were 34.7\% higher in treatment than control sections, while densities of steelhead parr were $9.2 \%$ lower in treatment than control sections. Statistically, there were no differences in mean densities for either species, in control and treatment sections. 


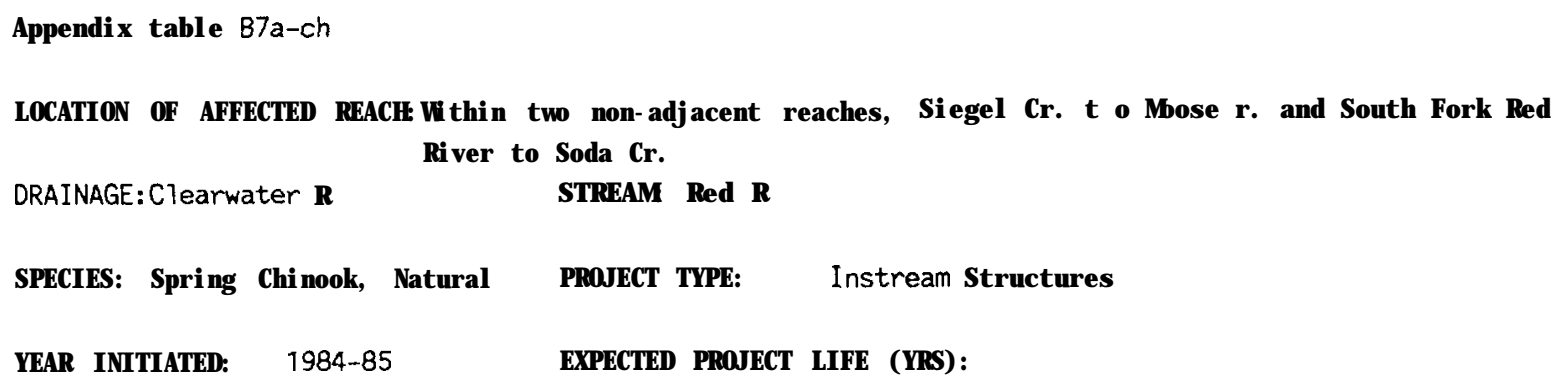

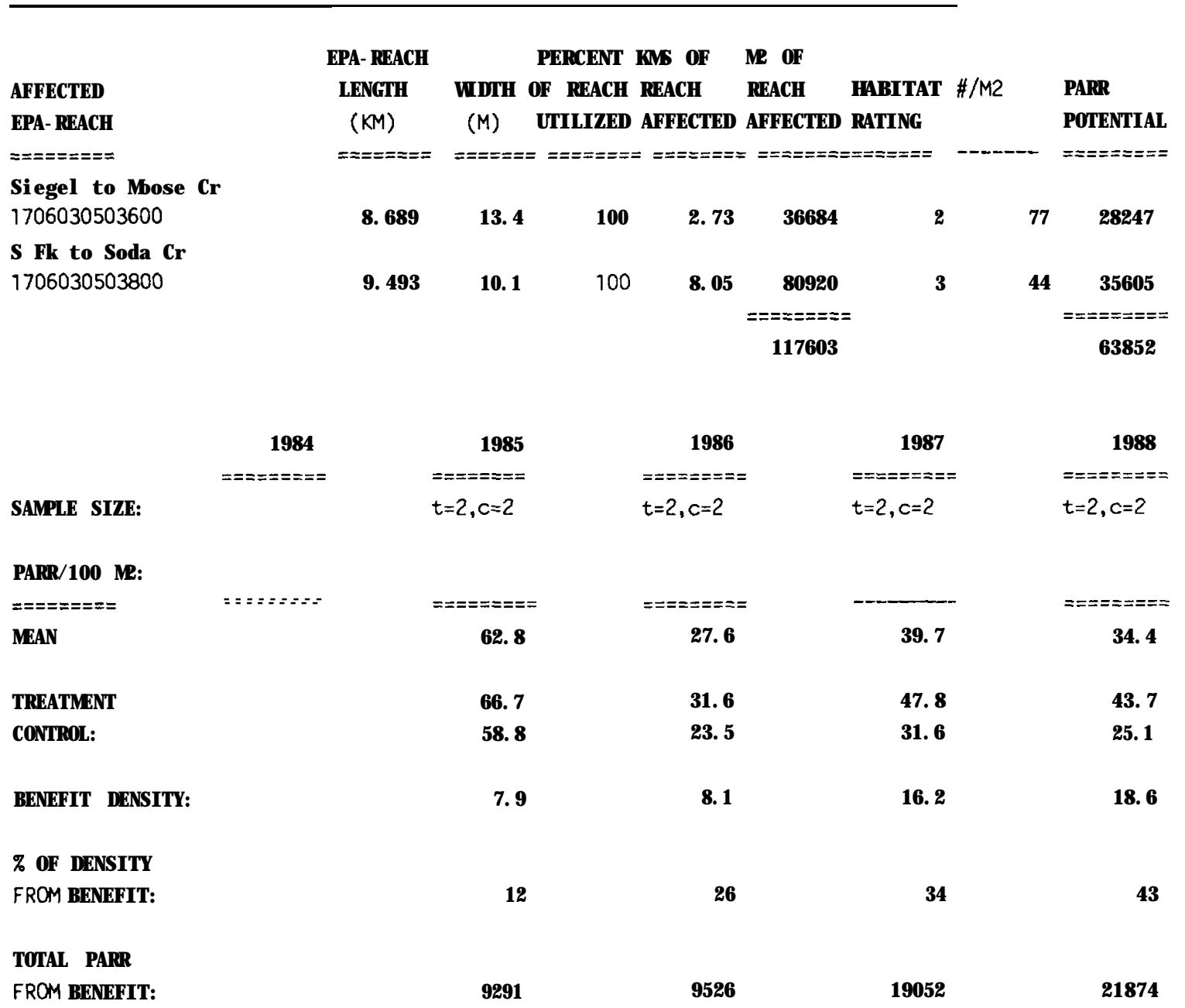




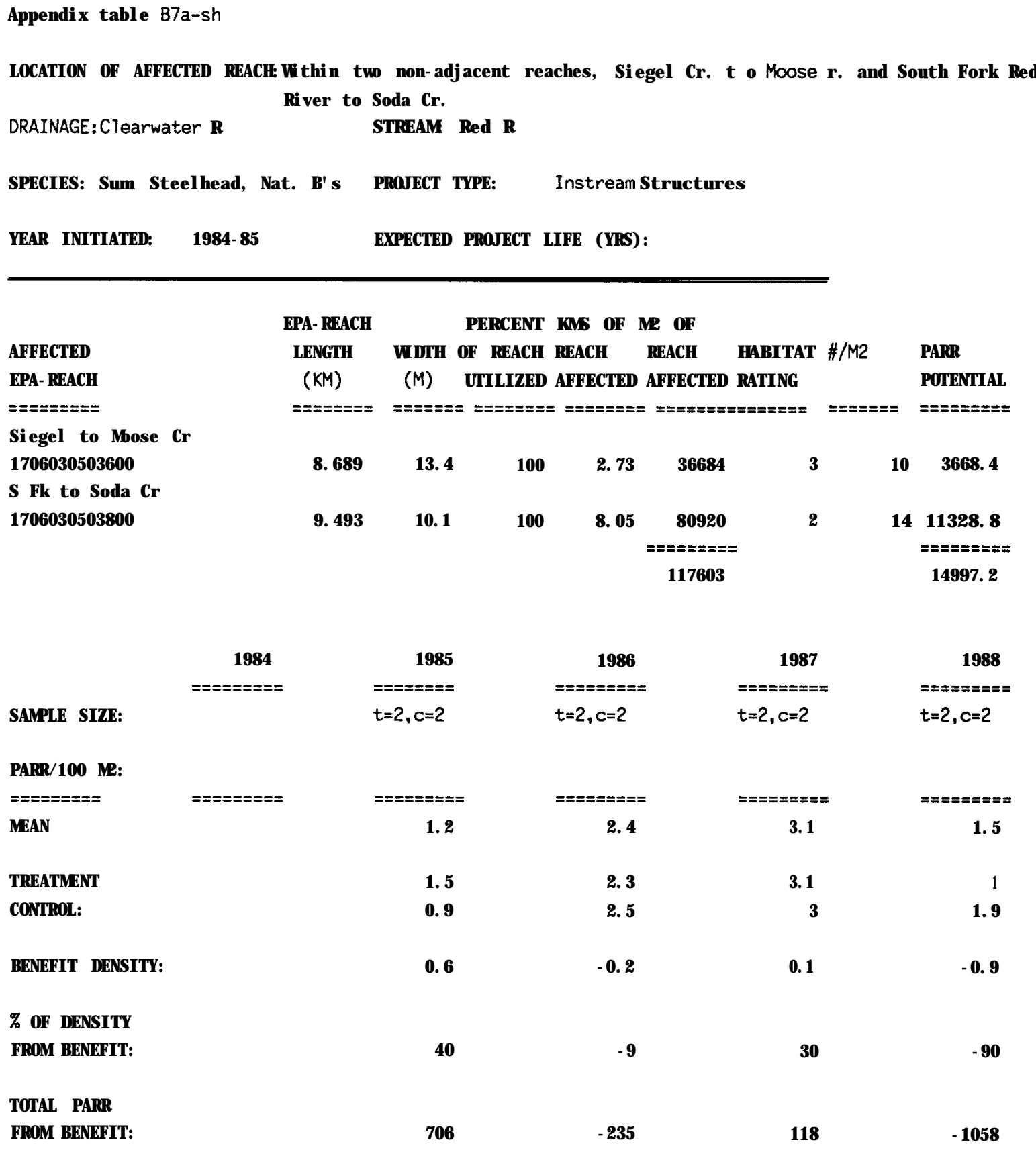


Appendix B-7b. (Red R., Continued).

Project Type: Off-channel developments

Year Implemented: 1985

Sponsor: Nez Perce National Forest

\begin{tabular}{|c|c|c|}
\hline \multirow[b]{2}{*}{ Enhancement } & \multicolumn{2}{|c|}{ Species Benefited } \\
\hline & B-Run Steelhead & Spring Chinook \\
\hline $\begin{array}{l}\text { Production Type: } \\
\text { Hectares Added: }\end{array}$ & $\begin{array}{c}\text { natural } \\
0.02\end{array}$ & $\begin{array}{c}\text { natural } \\
0.02\end{array}$ \\
\hline
\end{tabular}

Production Constraints: Limited opportunity for side-channel/pond development.

Definition of Benefits: The total abundance of steelhead and chinook parr in off-channel production areas are considered mitigation benefits.

In 1986, the numbers of steelhead and chinook parr estimated in the 0.02 hectares added totaled 1 and 215, respectively. No sampling has been done in the ponds in 1987 or 1988, but an analysis is planned for 1990. 
Appendix B-8. Proposed definition of mitigation benefits for implemented project in Pine Creek.

Project Type: Passage barrier

Year Implemented: 1987

Sponsor: Nez Perce National Forest

\begin{tabular}{lc}
\hline & Species Benefited \\
\cline { 2 - 2 } Enhancement & A-Run Steelhead \\
\hline Production Type: & natural \\
Hectares Added: & 6.9 \\
\hline
\end{tabular}

\section{Production Constraints:}

Definition of Benefits: A barrier to adult steelhead was removed by this project. However, we believe the barriers removed were not sufficient to allow adult steelhead to ascend Pine Creek, and that even with additional barrier removals, the gradient will be too steep to ensure passage. We recommend that parr density monitoring be terminated in Pine Creek.

Pine Creek was sampled in 1987 and 1988, but future sampling will be discontinued until complete barrier removal, if possible, occurs. 
Appendix B-9. Proposed definition of mitigation benefits for implemented project in Pole Creek.

Project Type: Diversion screen

year Implemented: 1983.1984

Sponsor: Sawtooth National Forest

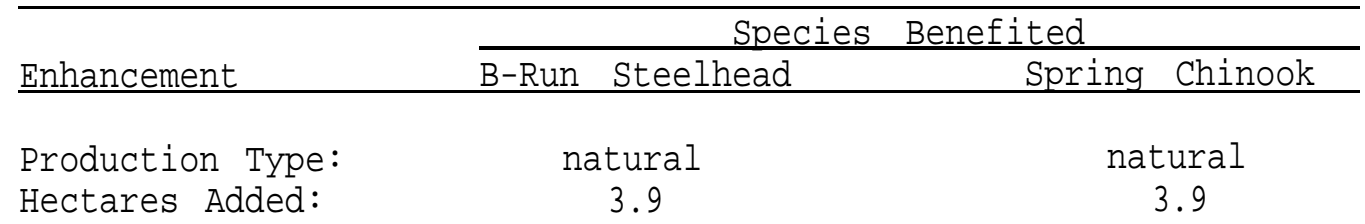

Production Constraints: Juvenile steelhead upstream passage is impeded.

Definition of Benefits: An unscreened irrigation diversion was screened. The proportion of steelhead and chinook parr reared upstream of the diversion that are screened from the ditch and returned to Pole Creek will be considered as mitigation benefits. The proportion was assumed to be $50 \%$ for these estimates. The upper Salmon River intensive study will determine this proportion during PIT tag operations and will directly estimate parr-to-smolt survival.

Estimated total abundance of steelhead parr upstream of the diversion was 420 in 1985 and 63 in 1987. Chinook have not been available for introduction upstream of the diversion. 
Appendix table B9-ch

LOCATION OF AFFECTED REACH: From the irrigation diversion upstream $7.94 \mathrm{~km}$.

DRAINAGE: Saimon $R$

SPECIES: Spring Chinook, Natural
STREAM: Pol e $\mathrm{Cr}$

PROJECT TYPE: Barrier (partial) Removal

EXPECTED PROJECT LIFE (YRS):

\begin{tabular}{|c|c|c|c|c|c|c|c|c|}
\hline & EPA-REACH & & PERCENT & KMS OF & M2 OF & & & \\
\hline AFFECTED & LENGTH & WI DTH & OF REACH & REACH & REACH & HABI TAT & $\# / M 2$ & PARR \\
\hline EPA. REACH & $(\mathrm{KM})$ & (M) & UTI LI ZED & AFFECTED & AFFECTED & RATI NG & & POTENTI AL \\
\hline$=====z===$ & $=======\mathbf{x}$ & $======$ & $=========$ & $=========$ & $========0$ & $========$ & $==ニ====$ & $==\pi== \pm==0$ \\
\hline 1706020114900 & 14.48 & 4.9 & 100 & 7.94 & 38862 & 2 & 71 & 29924 \\
\hline
\end{tabular}

\begin{tabular}{|c|c|c|c|c|c|}
\hline & 1984 & 1985 & 1986 & 1987 & 1988 \\
\hline & $========$ & $========$ & $== \pm== \pm= \pm=$ & 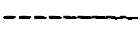 & $==:=\Xi=z=0$ \\
\hline SAMPLE SIZE: & $c=6$ & $t=6$ & $t=2$ & $t=6$ & $t=6$ \\
\hline
\end{tabular}

PARR/I 00 M2:

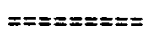

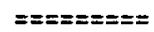

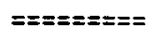

$==$ = $=$ = $=$

=ニ==ニ=ロ=+

=ニーニニニニー

MEAN

TRE AT ME NT

0

0

0.04

CONTROL

BENEFI T DENSI TY:

Z OF DENSITY

FROM BENEFI T:

TOTAL PARR

FROM BENEFI T: 
Appendix table B9-sh

LOCATION OF AFFECTED REACH:From the irrigation diversion upstream $7.94 \mathrm{~km}$.

DRAINAGE: Sa Imon $\mathrm{R} \quad$ STREAM: Pol e $\mathrm{Cr}$

SPECIES: Sum. Steelhead, Nat. B's PROJECT TYPE: Barrier (partial) Removal

YEAR INITIATED: 1984 EXPECTED PROJECT LIFE (YRS):

\begin{tabular}{|c|c|c|c|c|c|c|c|c|}
\hline & EPA. REACH & & PERCENT & KMS OF & M2 OF & & & \\
\hline AFFECTED & LENGTH & WI DTH & OF REACH & REACH & REACH & HABI TAT & $\# / M 2$ & PARR \\
\hline EPA- REACH & $(\mathrm{KM})$ & (M) & UTI LI ZED & AFFECTED & AFFECTED & RATI NG & & POTENTI AL \\
\hline$=========$ & trebrencere & $::::::$ & : $\quad======5$ & $=$ & $-\quad \cdots \ldots$ & $\ldots \ldots$ & $\underline{\ldots \ldots}$ & $\ldots \ldots \ldots$ \\
\hline 1706020114900 & 14.48 & 4.9 & 100 & 7,94 & 38862 & 3 & 10 & 3886.2 \\
\hline
\end{tabular}

\begin{tabular}{|c|c|c|c|c|c|}
\hline & 1984 & 1985 & 1986 & 1987 & 1988 \\
\hline & $==== \pm====$ & : : : : : : : : & : : : : : : : : & : : : : : : : : : & : : : : : : : : : \\
\hline SAMPLE SIZE: & $C=6$ & $t=6$ & $t=2$ & $t=6$ & $t=6$ \\
\hline
\end{tabular}

PARR/ 100 M2:

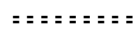

ME AN

TREATMENT

CONTROL

0

BENEFI T DENSI TY:

0.5

0.06

0.98

\% OF DENSI TY

FROM BENEFIT:

50

50

50

TOTAL PARR

FROM BENEFI T:

210 a

23

32 a

381

a. Total parr frombenefits is calculated from stratified sampling and multiplying the estimate by 0,5 to account for an assumed $50 \%$ benefit from the diversion screen. 
Appendix B-10. Proposed definition of mitigation benefits for implemented project, Bear Valley and Elk Creeks.

Project Type: Sediment reduction, riparian revegetation

Year Implemented: 1987 - ongoing

Sponsor: Boise National Forest

\begin{tabular}{lccc}
\hline & \multicolumn{3}{c}{ Species } \\
\cline { 2 - 4 } & & Middle Fonefited \\
Enhancement & B-Run & Steelhead & Sprinq Chinook \\
\hline & & Wild & Wild \\
Production Type: & 77 & 76 \\
Hectares to be Improved: & & \\
\hline
\end{tabular}

Production Constraints: High sediment levels, streambank degradation.

Definition of Benefits: The Bear Valley and Elk Creek project will attempt to significantly reduce sediment from point and nonpoint sources in the drainage and complement anticipated grazing management improvements. Benefits will be estimated based on: a) measured changes in sediment and fish-sediment relationships, b) improvements in egg deposition to parr survival, and c) an increase in the ratio of parr density in the Bear Valley/Elk Creek drainage to parr density in control streams throughout the upper Middle Fork drainage.

The ratio of parr $/ 100 \mathrm{~m}^{2}$ to redds/ha in the Bear Valley - Elk Creek spawning areas has shown no indication of increased parr survival from brood year 1983 to 1987 . The ratios were $5.5,2.5,1.8,0.8$, and 1.3 respectively (mean $=2.5$ ). The average value for this ratio among other Middle Fork and upper Salmon River sections was 18.7. Data used for these ratios were those used for the Middle Fork and upper Salmon River redd to parr analysis with additional observations removed when redd/ha $=0.0$. The average treatment/control density ratio for chinook averaged 0.05 in the pretreatment years of 1985 through 1987 . The ratio in 1988 after some sediment work, which began in 1987, was 0.12 . This small difference may not be a result of the project, but it demonstrates how the ratio will be used to determine benefits (Appendix Figure 1)

Evaluation of this sediment reduction project will be carried out when the project is complete (1991) and sufficient time has passed to allow bank stabilization and flushing of the accumulated sediment in the spawning areas of Bear Valley and Elk Creeks (approximately five years). Recovery of the aquatic habitat is expected to be a slow process and hinges on improved grazing management by the USFS (Appendix $\mathbf{C}$ ). 


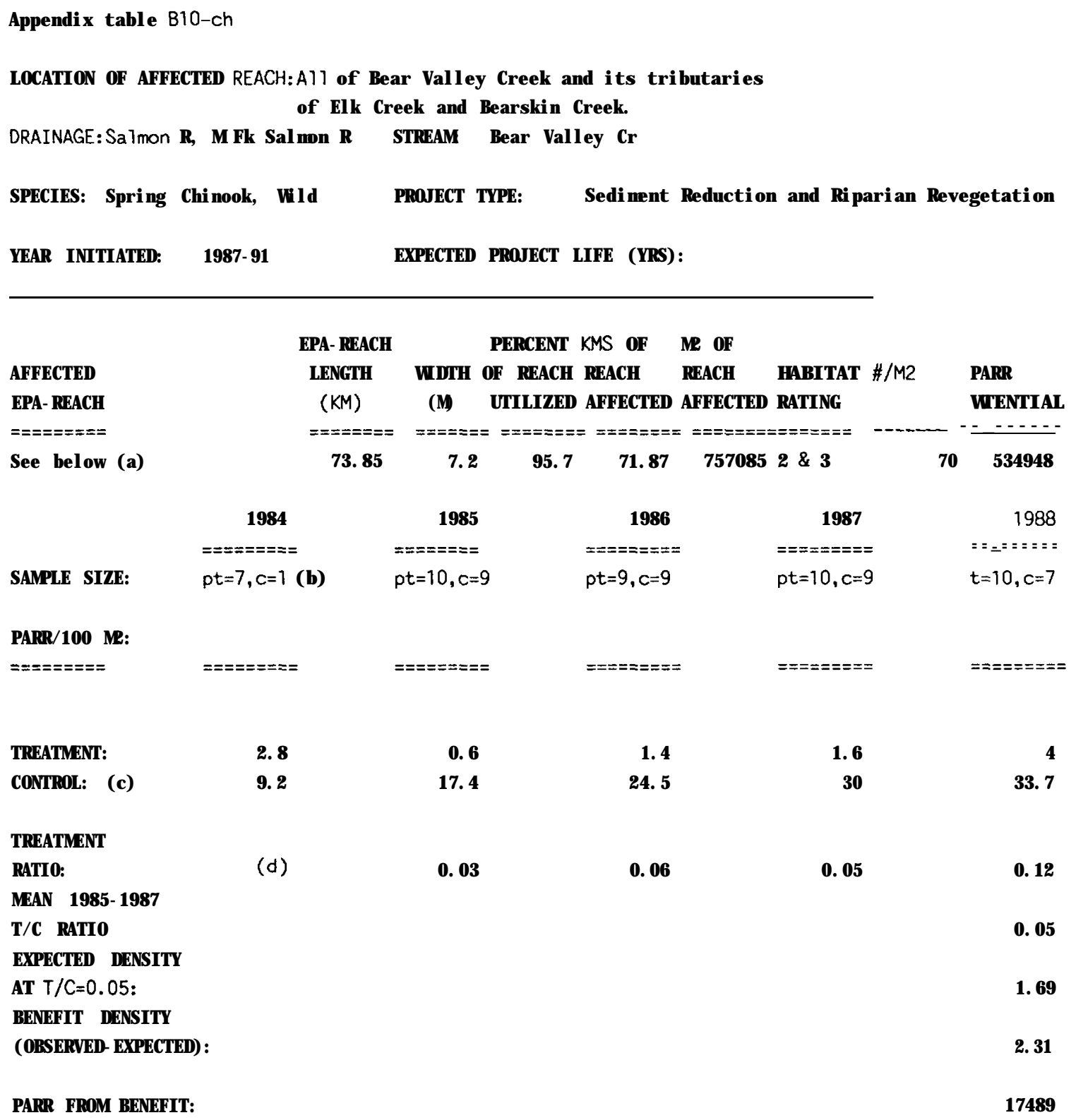

a. EPA reaches, al I beginning wi th 170602050 are: $2300,2400,2401,2402,2500,2501,2700,2701,2702$ $2800,2801,2802,2803,2600,2601,2602,2603,2604,2605,8400$ and 8401 .

b. $p t=p r e t r e a t m e n t$. Al thouth some improvements began in 1987, no significant reduction

in sediment and fish density response is expected until approximately 1991.

c. Control sections are in the Middle Fork Salmon River tributaries of knapp. Beaver, Cape Horn, Sulphur and Loon creeks.

d. Insufficient control sections with which to make a treatment/control ratio in 1984. 


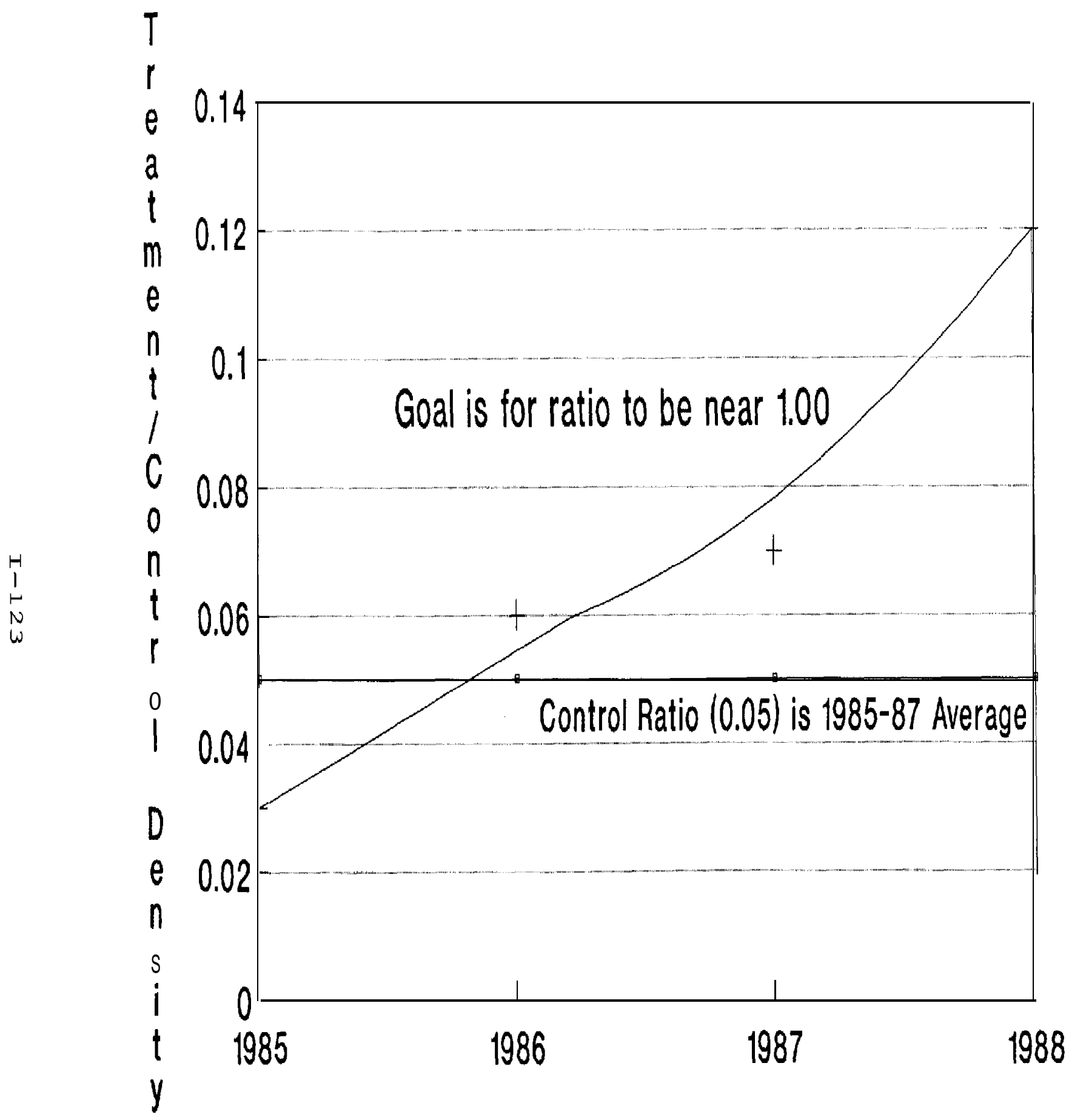

$\rightarrow$ Pre-Treat Ratio + Ratio Trend

Appendix Figure 1. Ratio of mean annual chinook parr density in Bear Valley/Elk Creek drainage relative to chinook parr densities in Middle Fork Salmon River control streams. 
Appendix table B10-sh

LOCATION OF AFFECTED REACH:AlT of Bear Valley Creek and its tributaries

of Elk Creek and Bearskin Creek.

DRAINAGE:Salmon R, M Fk Salmon R STREAM: Bear Valley $\mathrm{Cr}$

SPECIES: Sum. Steelhead, Wild B's PROJECT TYPE: Sedimentation Reduction and

Riparian Re-vegetation

YEAR I NITIATED: 1987.91 EXPECTED PROJECT LIFE (YRS):

\begin{tabular}{|c|c|c|c|c|c|c|c|c|}
\hline & EPA. REACH & & PERCENT & KMS OF & M2 OF & & & \\
\hline AFFECTED & LENGTH & WI DTH OF & OF REACH & REACH & REACH & HABITAT & $\# / M 2$ & PARR \\
\hline EPA-REACH & $(K M)$ & (M) U & UTI LI ZED & AFFECTED & AFFECTED & RATING & & POTENTI AL \\
\hline$==ニ==ニ=ニ=$ & 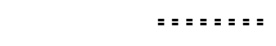 & ::::::: & $\ldots \ldots$ & $-\overline{=}$ & - & $=\quad-$. & $======-$ & 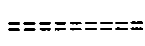 \\
\hline \multirow[t]{2}{*}{ See below (a) } & 73.85 & 7.2 & 100 & 73.85 & 768737 & $\cdot 3$ & 13.7 & 105333 \\
\hline & $\begin{array}{c}1984 \\
========\end{array}$ & 1985 & & 1986 & & $\begin{array}{r}1987 \\
\ldots \ldots \ldots \\
\end{array}$ & & $\begin{array}{r}1988 \\
\text { = = ニ ニ ニ }\end{array}$ \\
\hline SAMPLE SIZE: & $p t=?, c=1(b)$ & $p t=10, c=9$ & & $p t=9, c=9$ & & $p t=10, c=9$ & & $t=10, c=7$ \\
\hline \multicolumn{9}{|l|}{ PARR/ 100 M2: } \\
\hline 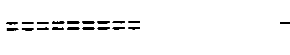 & $\overline{\overline{ }}$ & 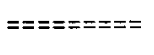 & & 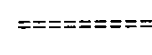 & & : : : : : : : : : & & 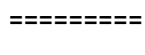 \\
\hline TRE AT ME NT: & 0.06 & 0.3 & & 0.2 & & 0.01 & & 0.12 \\
\hline CONTROL: $\quad(C)$ & 0 & 0.9 & & 1.4 & & 1,5 & & 2.7 \\
\hline \multicolumn{9}{|l|}{ T RE AT ME NT } \\
\hline RATI O: & (d) & 0.33 & & 0.14 & & 0.007 & & 0.04 \\
\hline \multicolumn{9}{|l|}{ MEAN $1985-1987$} \\
\hline $\begin{array}{l}\text { EXPECTED DENSITY } \\
\text { AT } T / C=0.05:\end{array}$ & & & & & & & & 0.43 \\
\hline $\begin{array}{l}\text { BENEFI T DENSI TY } \\
\text { ( OBSERVED. EXPECTED): }\end{array}$ & & & & & & & & $\cdot 0.31$ \\
\hline PARR FROM BENEFI T: & & & & & & & & .2383 \\
\hline
\end{tabular}

a. EPA reaches, all beginning with 170602050 are: $2300,2400,2401,2402,2500,2501,2700,2701,2702$ $2800,2801,2802,2803,2600,2601,2602,2603,2604,2605,8400$ and 8401 .

b. pt=pretreatment. Al thouth some improvements began in 1987, no significant reduction

in sediment and fish density response is expected until approximately 1991.

c. Control sections are in the Middle Fork Sal mon River tributaries of knapp, Beaver, Cape Horn, Sulphur and Loon creeks.

d. Insufficient control sections with which to make a treatment/control ratio in 1984. 
Appendix B-11. Proposed definition of mitigation benefits for implemented project, Knapp Creek.

Project type: Passage barrier (diversion structure bypassed)

Year implemented: $\quad 1987$

Sponsor: Challis National Forest

\begin{tabular}{lc}
\hline & Species benefited \\
\cline { 2 - 2 } Enhancement & Spring Chinook \\
\hline Production type & wild \\
Hectares added & 7.8 \\
\hline
\end{tabular}

\section{Production constraints:}

Definition of benefits: An irrigation diversion that partially blocked adult chinook passage was modified. Benefits will be estimated as $50 \%$ of total abundance of chinook parr reared above the barrier. Parr density estimates in 1987 and 1988 were based on one sample each year. Once obvious density increases appear, we will evaluate benefits based on multiple samples and stratified sampling.

The barrier was removed during the summer of 1987 and could have provided adult chinook passage that year and parr density benefits in 1988. Although the percent of parr carrying capacity above the barrier has remained below $1 \%$, percent chinook carrying capacity below the barrier has ranged from $7-21 \%$ and pioneering above the barrier is likely. 
Appendix table Bllech

LOCATION OF AFFECTED REACH:All of of Upper Knapp Creek, beginning $3.5 \mathrm{~km}$ above the mouth.

DRAINAGE: Saimon R, MFk SaImon R, STREAM: Knapp Cr Marsh $\mathrm{Cr}$

SPECIES: Spring Chinook, Wild PROJECT TYPE: Barrier (partial) removal

YEAR INITIATED: 1987 EXPECTED PROJECT LIFE (YRS): 50t

\begin{tabular}{|c|c|c|c|c|c|c|c|c|}
\hline & EPA. REACH & & PERCENT & MMS OF & M2 OF & & & \\
\hline AFFECTED & LENGTH & WI DTH & OF REACH & REACH & REACH & HABI TAT & $\# / M 2$ & PARR \\
\hline EPA. REACH & $(K M)$ & ( M) & UTI LI ZED & AFFECTED & AFFECTED & RATING & & POTE NTI AL \\
\hline$======\pi=\mathbf{z}$ & $===\pi=\pi=$ & $=====$ & $==\quad======$ & $==\quad== \pm===$ & $:=== \pm= \pm=0$ & $===== \pm==$ & 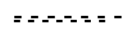 & $=$ =ニニニニ=ニ= \\
\hline 1706020503503 & 23.33 & 4,57 & 786 & 12.3 & 77815 & 1 & 108 & 84040 \\
\hline
\end{tabular}

\begin{tabular}{|c|c|c|c|c|c|}
\hline & 1984 & 1985 & 1986 & 1987 & 1988 \\
\hline & I=ニ=ニニ=ニ= & =ニニニニニニニ & $== \pm==ニ=ニ=$ & ニニニニニニニニニ & $z==ニ=ニ=ニ=$ \\
\hline SAMPLE SIZE: & & $c=2$ & $c=1$ & $c=1$ & $t=1$ \\
\hline
\end{tabular}

PARR/ 100 M2:

=ニ=ニ=ニニニ

=ニニニニニニニニ

エニッニニニニニ

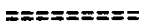

=ニニニニニニニニ

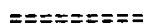

ME A N

TREATME NT

CONTROL

0.29

0

0.15

0.16

0.08

BENEF I T DENSI TY:

\% OF DENSITY

FROM BENEFIT:

50

TOTAL PARR

FROM BENEFI T:

$226 a$

117 a

63

a. Barrier removal during the summer of 1987 could have provided for upstream passage for adults that year. Chinook parr from the 1987 brood year would be monitored in 1988. 
Appendix B-12. Proposed definition of mitigation benefits for implemented project, Johnson Creek.

Project Type: Passage barrier

Year Implemented: $\quad 1984-1986$

Sponsor: Idaho Department of fish and Game

\begin{tabular}{lc}
\hline & Species Benefited \\
\cline { 2 - 2 } Enhancement & Summer Chinook \\
Production Type: & natural \\
Hectares Added: & 39.5 \\
\hline
\end{tabular}

Production Constraints: High sediment levels in portions of the drainage.

Definition of Benefits: Natural rock barriers that completely blocked adult chinook passage were modified. Benefits are estimated from total abundance of chinook parr reared above barriers.

A total of $50,744,177,606,118,424$, and 366,800 summer chinook fry were stocked into the upper Johnson Creek drainage in 1985, 1986, 1987, and 1988. Total abundance of parr from the 1986 and 1987 plants were estimated at 23,700 and 17,700, respectively. Average fry-to-parr survival was 14.2\%. Fry stocking did not fully seed the drainage either year. For the monitoring years of 1985 and 1988, 14.2\% fry-to-parr survival was used. 
Appendix table B12-ch

LOCATION OF AFFECTED REACH: Upstream from the I ower barrier removal site $24.6 \mathrm{~km}$ upstream to

headwaters including tributaries of Rock, Sand, Whisky and Boulder creeks.

DRAI NAGE:SaImon R, S Fk SaImon R, STREAM: Johnson Cr

E Fk S Fk Salmon R

SPECIES: Surmer Chinook, Natural PROJECT tYPE: Barrier Removal

year INItIAted: $1984 \quad$ eXPeCted Project life (YRS): $50+$

\begin{tabular}{|c|c|c|c|c|c|c|c|}
\hline & EPA. REACH & & PERCENT KMS OF & M2 OF & & & \\
\hline AFFECTED & LENGTH & WI DTH & OF REACH REACH & REACH & HABI TAT & \#/M2 & PARR \\
\hline EPA-REACH & $(K M)$ & $(M)$ & UTILIZED AFFECTED & AFFECTED & RATI NG & & POTENTI AL \\
\hline See below (a) & 64.68 & 8.04 & 85.9 & 395119 & $1 \cdot 3$ & 74.6 & 294750 \\
\hline
\end{tabular}

\begin{tabular}{|c|c|c|c|c|c|}
\hline & 1984 & 1985 & 1986 & 1987 & 1988 \\
\hline & …....... & =: =: =: =: & : : : : : : & ::::::: & : ::: : : \\
\hline SAMPLE SIZE: & $c=23$ & $t=10$ & $t=10$ & $t=11$ & $t=7$ \\
\hline
\end{tabular}

PARR/I 00 M2:

$=====+=$

MEAN

TREATMENT

CONTROL

0

BENEFI T DENSITY:

\% OF DENSITY

FROM BENEFI T:

TOTAL PARR

FROM BENEFIT:

7206 b

$23711 b$

$17700 \quad b$

$52086 \quad b$

a. EPA reaches affected all begin with 170602080 and end with: 4700, 4701, 4701.13, 4701.24, 4702, 4703. $4704,9800,7400,9600,9700$.

b. Populations above the barrier were estimated in 1986 and 1987 with stratified sampling. Average fry to parr survival was $14.2 \%$. Population estimates in 1985 and 1988 are the product of number of fry planted and 0.142. Maxi mum summer parr population achieved (in 1988) equated to $18 \%$ of carrying capacity. 
Appendix B-13. Proposed definition of mitigation benefits for implemented project in Dollar Creek.

Project Type: Passage barrier (partial)

Year Implemented: 1986

Sponsor: Boise National Forest

\begin{tabular}{|c|c|c|}
\hline & $\begin{array}{r}\text { Species Ben } \\
\end{array}$ & ited \\
\hline Enhancement & $\begin{array}{c}\text { South Fork Salmon River } \\
(B-\text { Run }) \\
\text { Steelhead }\end{array}$ & Spring Chinook \\
\hline $\begin{array}{l}\text { Production Type: } \\
\text { Hectares Added: }\end{array}$ & $\begin{array}{r}\text { wild } \\
6.8\end{array}$ & $\begin{array}{c}\text { natural } \\
3.3\end{array}$ \\
\hline
\end{tabular}

Production Constraints: High sediment levels

Definition of Benefits: Debris jam barriers that partially blocked passage were selectively removed. Parr benefits for 1986-1988 were based on densities in a single monitoring section. The barriers were assumed to block $50 \%$ of adult chinook and steelhead passage, and this percent of the parr density is attributed to the project. 
Appendix table B13-ch

LOCATION OF AFFECTED REACH:A11 of DOIlar Creek.

DRAINAGE:SaImon R. S Fk Salmon R STREAMi Dollar $\mathrm{Cr}$

SPECIES: Summer Chinook, Natural PROJECT TYPE: Barrier (partial) removal

YEAR INITIATED: 1986 EXPECTED PROJECT LIFE (YRS):

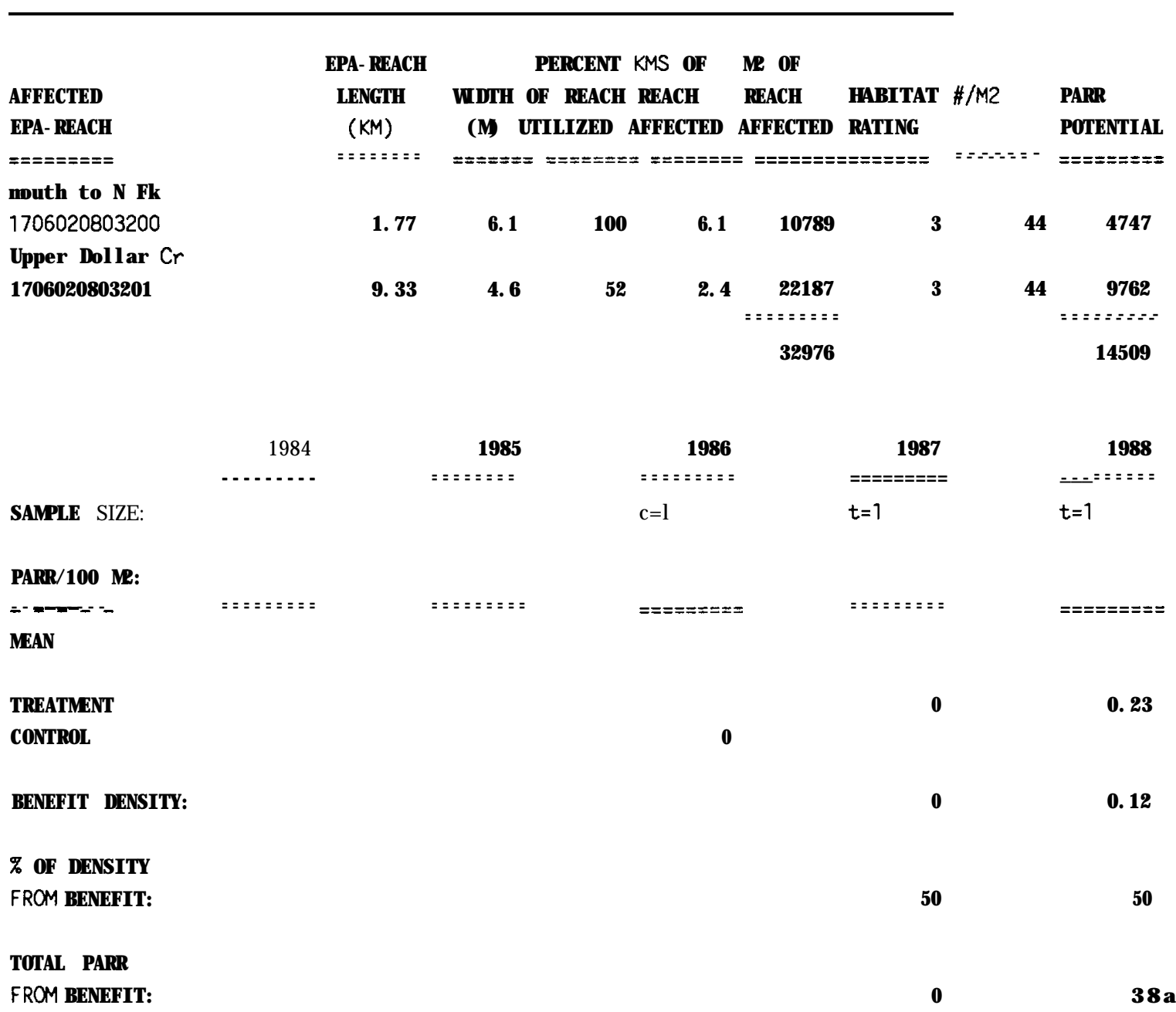

a. Equates to $50 \%$ of parr estimated above barriers since barriers were assumed to block $50 \%$ of adult chinook spawners. 
Appendix table B13-sh

LOCATION OF AFFECTED REACH:A11 of DOII ar Creek.

DRAI NAGE: Sal mon $R$, S Fk Salmon $R$ STREAM: Dollar $\mathrm{Cr}$

SPECIES: Sum. Steelhead, Wi Id B's PROJECT TYPE: Barrier (partial) removal

YEAR INITIATED: 1986 EXPECTED PROJECT LIFE (YRS):

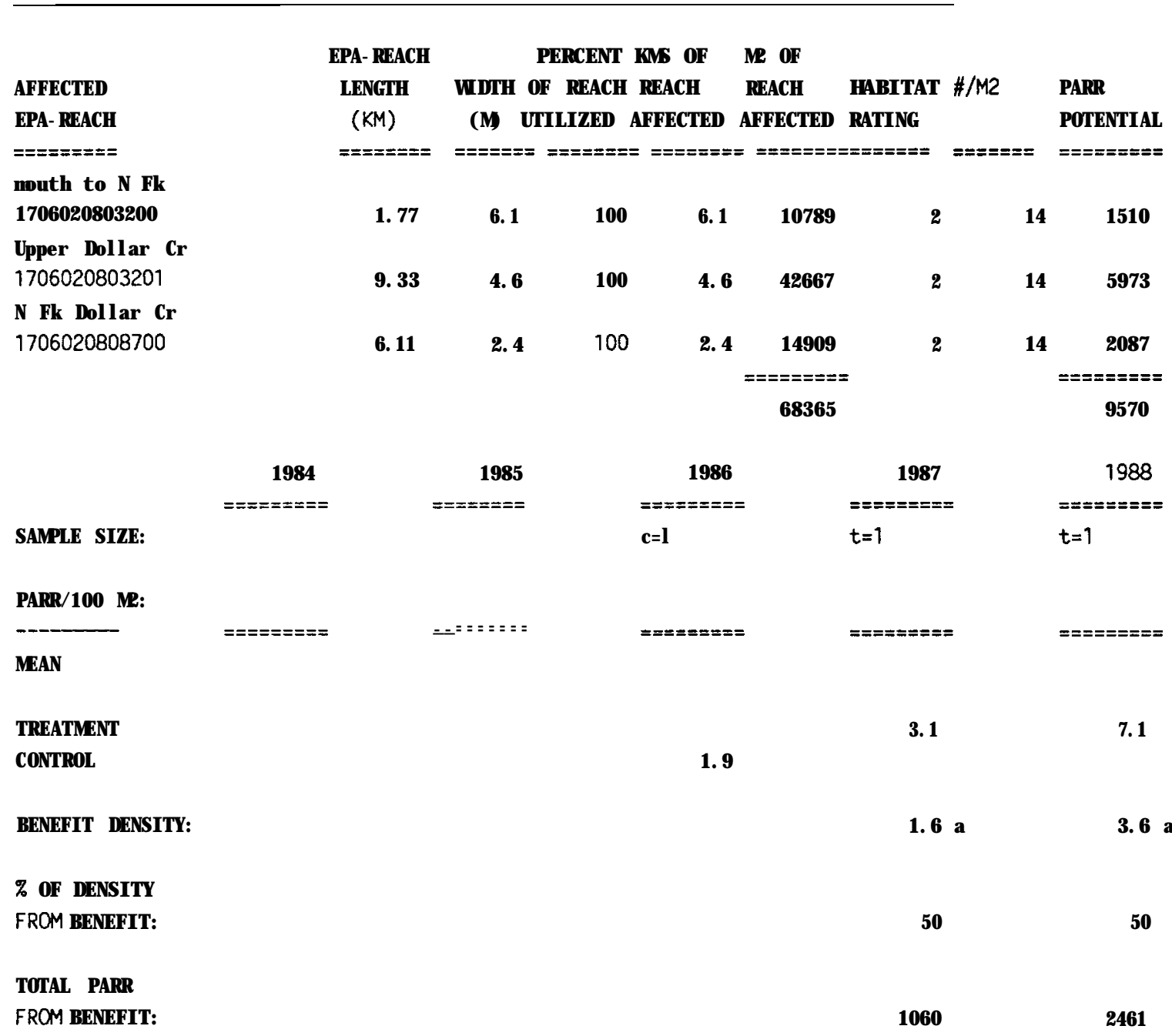

a. Equates to $50 \%$ of parr estimated above barriers since barriers were assumed to block $50 \%$ of adult steelhead spawners. 
Appendix B-14. Proposed definition of mitigation benefits for implemented project in Boulder Creek.

Project Type: Passage barrier

Year Implemented: 1985

Sponsor: Idaho Department of Fish and Game

Enhancement

Species Benefited

Spring Chinook

Production Type:

natural

Hectares Added:

11.2

\section{Production Constraints:}

Definition of Benefits: A barrier falls that was a nearly complete block to adult chinook was modified. Benefits will be based on total chinook parr abundance.

Stratified sampling was used to estimate fry-to-parr survival in 1986 and eyed egg-to-parr survival in 1988. An estimated total of 28,100 chinook parr were reared in 1986 from a May release of 99,000 fry. In 1988, 1,560 chinook parr were estimated to have survived from a plant of 140,000 eyed-eggs in october, 1987. Survival rates to the summer parr life stage were $28.1 \%$ for planted fry and $1.1 \%$ for planted eggs. 
Appendix table $14 \cdot c h$

LOCATI ON OF AFFECTED REACH:Upper Boulder Creek, beginning at the barrier removal site, approximately $6.4 \mathrm{~km}$ above the mouth.

DRAINAGE: Salmon R, I ittle Salmon R STREAM: Boulder Cr

SPECIES: Spring Chinook, Natural PROJECT TYPE: Barrier removal

YEAR INITIATED: 1985 EXPECTED PROJECT LIFE (YRS):

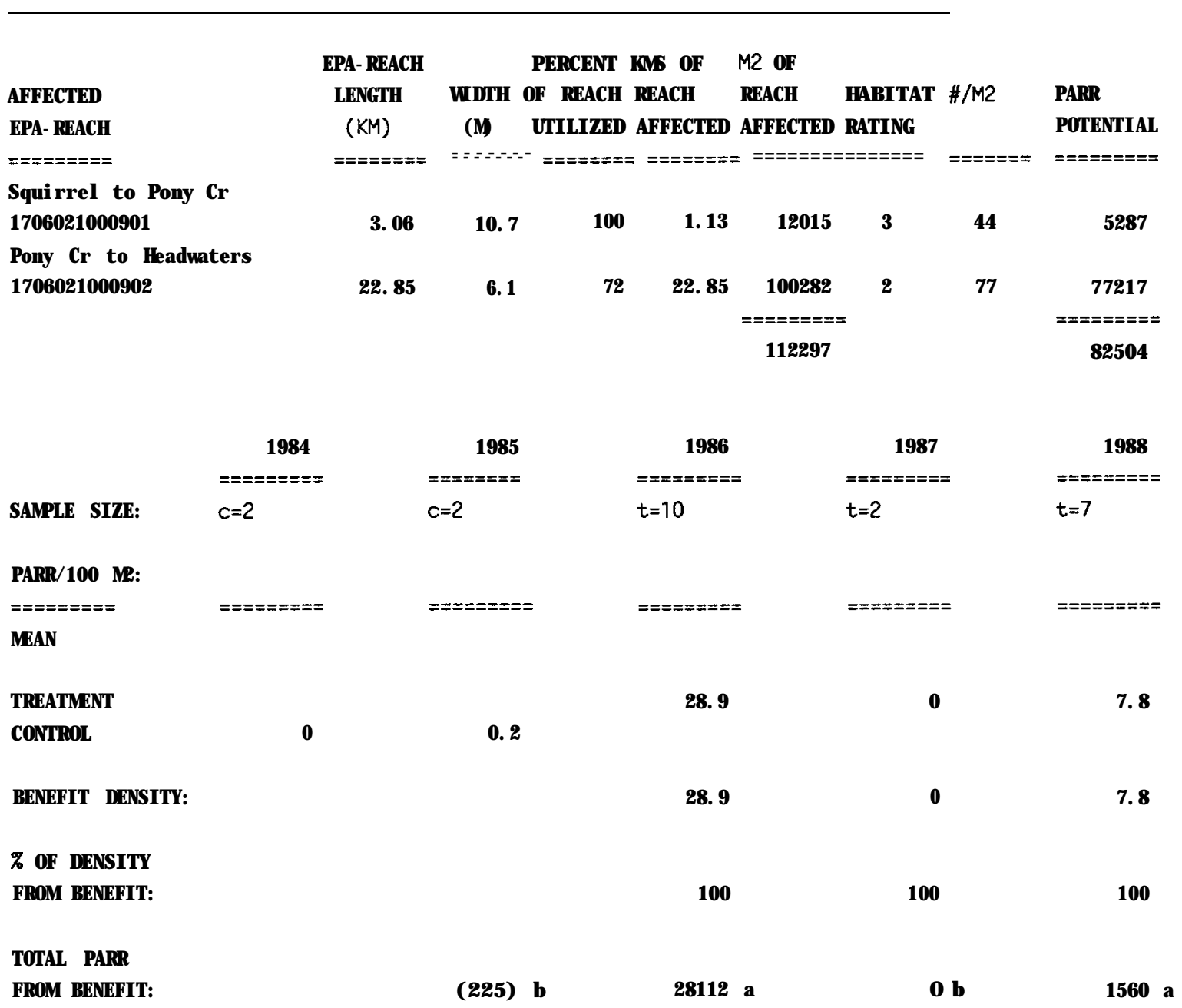

a. Estimates from stratified sampling.

b. Estimates from average parr density*surface area/100. Par observed in 1985 demonstrates that some chinook wereable to pass the barriers at least in high water years such as 1984. 
Appendix B-15. Proposed definition of mitigation benefits for implemented project in Meadow Creek.

Project Type: Passage barrier

Year Implemented: 1987

Sponsor: Nez Perce National Forest

Enhancement

Species Benefited

Spring Chinook

Production Type:

Hectares Added:

natural

8.9

Production Constraints: Grazing impacts: sediment production and riparian degradation.

Definition of Benefits: A barrier to adult chinook passage was removed in 1987, and 100,000 chinook fry were planted above the barrier in the spring of 1988. Parr density was monitored at two sections in 1988, but estimated summer parr population from the fry stocking was based on the project-wide fry-to-parr survival rate of $15 \%$. 
Appendix table B15-ch

LOCATION OF AFFECTED REACH: From mouth to headwaters of Meadow Creek.

DRAI NAGE: Cl ear water R,

$S \mathrm{Fk} \mathrm{Clearwater} \mathrm{R}$

SPECIES: Spring Chinook, Natural

YEAR I NI TIATED:

1987
STREAM: Meadow $\mathrm{Cr}$

PROJECT TYPE: Barrier Removal

EXPECTED PROJECT LIFE (YRS):
$50+$

\begin{tabular}{|c|c|c|c|c|c|c|c|}
\hline$E P A \cdot R E A C H$ & & PERCENT & KMS OF & M2 OF & & & \\
\hline LENGTH & WI DTH & OF REACH & REACH & REACH & HABI TAT & $\# / M 2$ & PARR \\
\hline (KM) & ( M) & UTI LI ZED & AFFECTED & AFFECTED & RATING & & POTENTI AL \\
\hline$========$ & $======$ & $=======$ & $======\pi=$ & $===== \pm==$ & $====== \pm=$ & $=======$ & $====$ = = = = \\
\hline 21.72 & 6.1 & 67 & 21,72 & 88710 & 3 & 44 & 39036 \\
\hline
\end{tabular}

AFFECTED

EPA. REACH

$====== \pm==$

1706030504800

\author{
$======= \pm$
}

SAMPLE SIZE:

PARR/ 100 M2:

$==== \pm====$

MEAN

TREATMENT

CONTROL

BENEFI T DENSI TY:

\% OF DENSITY

FROM BENEFI T:

TOTAL PARR

FROM BENEFI T:

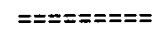

==ニニ=ニニ=ニ

$\mathrm{c}=2$

$t=2$

31.27

31.27

100

15000 a

a. This equals $15 \%$ of the 100,000 fry planted that spring. This $(15 X)$ is the average

fry to parr survival observed from stratified sampling in the project, state wide. 
Appendix B-16. Proposed definition of mitigation benefits for implemented project on Valley Creek.

Project Type: Passage Barrier (irrigation diversion)

Year implemented: 1988

Sponsor: Boise National Forest

\begin{tabular}{lc}
\hline \multirow{2}{*}{ Enhancement } & Species Benefited \\
\cline { 2 - 2 }
\end{tabular}

Production Type Wild

Hectares Enhanced 20.0

\section{Production Constraints:}

Definition of Benefits: A partial barrier to adult chinook, in the form of an irrigation diversion, was removed. Benefits will be determined as a fraction of chinook parr rearing above the barrier. Tentatively, an annual average benefit will be $70 \%$ of the parr density. 
Appendix table B16-ch

LOCATI ON OF AFFECTED REACH: Beginning at irrigation diversion near mouth of Trap Creek and continuing from there to headwaters.

DRAINAGE: Sa Tmon R

STREAM: Valley $\mathrm{Cr}$

SPECIES: Spring Chinook, Wild

PROJECT TYPE: Barrier (partial) removal

YEAR I NI TI ATED: 1988

EXPECTED PROJECT LIFE (YRS):

$50+$

\begin{tabular}{|c|c|c|c|c|c|c|c|c|}
\hline & EPA. REACH & & PERCENT & KMS OF & M2 OF & & & \\
\hline AFFECTED & LENGTH & WI DTH & OF REACH & REACH & REACH & HABI TAT & $\# / M 2$ & PARR \\
\hline EPA. REACH & (KM) & ( M) & UTI LI ZED & AFFECTED & AFFECTED & RATING & & PDTENTI AL \\
\hline$= \pm===== \pm=$ & $========$ & $===== \pm=$ & $===:====0$ & 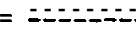 & - =:===== & $=====\because==$ & $======$ & $== \pm======$ \\
\hline Trap $\mathrm{Cr}$ to headwaters & & & & & & & & \\
\hline 1706020105500 & 19.63 & 6.1 & 100 & 19.63 & 199663 & 2 & 77 & 92141 \\
\hline
\end{tabular}

SAMPLE SIZE:

$c=8$

$c=1$

$c=1$

$c=1$

PARR/ 100 M2:

$========$

$==ニ==ニ=ニ=$

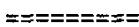

$==== \pm===0$

$==ニ==ニ+==$

$===ニ=ニ==$

MEAN

TREATMENT

CONTROL

12.4

0

BENEFI T DENSI TY:

\% OF DENSITY

FROM BENEFI T:

TOTAL PARR

FROM BENEFI T: 
Appendix C. Percent surface sand and density of wild chinook and steelhead parr in established monitoring sections in the heavily sedimented Bear Valley/Elk Creek drainage and control streams in the Middle Fork Salmon River drainage, 1985.1988.

\begin{tabular}{|c|c|c|c|c|c|c|c|c|c|c|c|}
\hline \multicolumn{3}{|l|}{ Stream } & \multirow{2}{*}{$\begin{array}{l}\text { Percent } \\
\text { Sand }\end{array}$} & \multicolumn{2}{|c|}{ Chinook P } & Parr/ 100 & \multirow{2}{*}{$\begin{array}{l}\mathrm{m} 2 \\
1988\end{array}$} & \multicolumn{3}{|c|}{ Steel head Parr/100 } & \multirow{2}{*}{$\begin{array}{l}\mathrm{m} 2 \\
1988\end{array}$} \\
\hline Condition & Stream & Section & & 1985 & 1986 & 1987 & & 1985 & 1986 & 1987 & \\
\hline \multicolumn{2}{|c|}{ 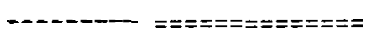 } & $==\approx==$ & $=== \pm=$ & \multicolumn{4}{|c|}{ 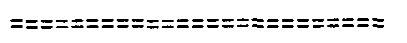 } & \multicolumn{4}{|c|}{ 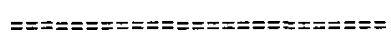 } \\
\hline Sedi ment & Bear Valley & $2 \mathrm{~A}$ & 43 & 1.9 & 3.0 & 0.9 & 4.2 & 0.1 & 0.1 & 0.0 & 0.0 \\
\hline Reduction & Creek & $2 \mathrm{~B}$ & 71 & 0.0 & 0.3 & 0.0 & 0.0 & 0.0 & 0.0 & 0.0 & 0.0 \\
\hline \multirow[t]{9}{*}{ Required } & $"$ & $3 \mathrm{~A}$ & 25 & 1.0 & 4.7 & 7.7 & 5.6 & 0.0 & 0.8 & 0.1 & 0.3 \\
\hline & $"$ & $5 \mathrm{~A}$ & 28 & 0.2 & 4.1 & 1.3 & 2.9 & 0.0 & 0.0 & 0.0 & 0.2 \\
\hline & $"$ & $9 B$ & 55 & 0.0 & 0.0 & 2.2 & 2.6 & 0.0 & 0.0 & 0.0 & 0.0 \\
\hline & Elk Creek & $1 \mathrm{~A}$ & 44 & 0.4 & 0.0 & 0.1 & 0.1 & 0.4 & 0.0 & 0.0 & 0.1 \\
\hline & $"$ & $1 \mathrm{~B}$ & 54 & 1.4 & 0.6 & 0.1 & 11.9 & 7.4 & 0.6 & 0.0 & 0.3 \\
\hline & 11 & $2 \mathrm{~A}$ & 53 & 0.0 & 0.0 & 0.0 & 0.2 & 0.0 & 0.1 & 0.0 & 0.0 \\
\hline & $"$ & 28 & 37 & 1.1 & 0.2 & 3.8 & 11.6 & 1.1 & 0.2 & 0.0 & 0.3 \\
\hline & & & \multicolumn{5}{|c|}{ 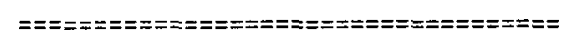 } & \multicolumn{4}{|c|}{ 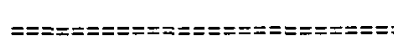 } \\
\hline & Treatment Means: & & 45.6 & 0.7 & 1.4 & 1.8 & 4.3 & 0.3 & 0.2 & 0.0 & 0.1 \\
\hline Control & Knapp $\mathrm{Cr}$. & $1 \mathrm{~A}$ & 26 & 23.6 & 7.2 & 10.4 & 11.1 & 1.1 & 0.7 & 3,5 & 3,4 \\
\hline \multirow[t]{8}{*}{ Streams } & Beaver $\mathrm{Cr}$. & $1 \mathrm{~A}$ & 4 & 12.9 & 7.2 & 0.5 & 9.8 & 1.4 & 0.0 & 0.1 & 1.2 \\
\hline & $"$ & $3 B$ & 11 & 10.8 & 28.6 & 5.9 & 26.8 & 7.2 & 2.1 & 0.7 & 2.4 \\
\hline & Cape Horn $\mathrm{Cr}$. & $2 B$ & 20 & 49.0 & 10.7 & 96.8 & 55.7 & 0.2 & 0.0 & 0.0 & 0.0 \\
\hline & $"$ & $1 \mathrm{~A}$ & 8 & 34.7 & 14,5 & 39.4 & 40.7 & 0.1 & 0.6 & 0.9 & 4.2 \\
\hline & Sulphur $\mathrm{Cr}$. & $4 \mathrm{~A}$ & 36 & 0.1 & 25.8 & 39.9 & 24.1 & 0.0 & 0.3 & 3.2 & 3.4 \\
\hline & 11 & $4 B$ & 30 & 18.1 & 62.6 & 18.8 & 67.9 & 1.0 & 1.0 & 0.2 & 4.4 \\
\hline & & & \multicolumn{5}{|c|}{ 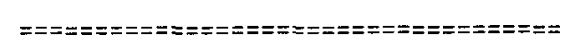 } & \multicolumn{4}{|c|}{$=\geq$ } \\
\hline & Control Means: & & 19.6 & 21.3 & 22.4 & 30.2 & 33.7 & 0.7 & 0.7 & 1.2 & 2.7 \\
\hline
\end{tabular}


Appendix C. Percent surface sand and density of wild chinook and steel head parr in established monitoring sections in the heavily sedimented Bear Valley/Elk Creek drainage and control streams in the Middle Fork Salmon River drainage, 1985.1988.

\begin{tabular}{|c|c|c|c|c|c|c|c|c|c|c|c|}
\hline \multirow{2}{*}{$\begin{array}{l}\text { Stream } \\
\text { Condition }\end{array}$} & \multirow[b]{2}{*}{ Stream } & \multirow{3}{*}{ Section } & \multirow{2}{*}{$\begin{array}{l}\text { Percent } \\
\text { Sand }\end{array}$} & \multicolumn{2}{|c|}{ Chinook } & Parr/100 & \multirow{2}{*}{$\begin{array}{l}\mathrm{m} 2 \\
1988\end{array}$} & \multicolumn{2}{|c|}{ Steel head } & Parr/ 100 & \multirow{2}{*}{$\begin{array}{l}\mathrm{m} 2 \\
1988\end{array}$} \\
\hline & & & & 1985 & 1986 & 1987 & & 1985 & 1986 & 1987 & \\
\hline & & & $=====$ & $=====$ & $z==-==$ & $========$ & $======$ & $=====$ & $===-==$ & $===-===-$ & $=== \pm==$ \\
\hline Sedi ment & Bear Valley & $2 A$ & 43 & 1.9 & 3.0 & 0.9 & 4.2 & 0.1 & 0.1 & 0.0 & 0.0 \\
\hline Reduction & Creek & $2 B$ & 11 & 0.0 & 0.3 & 0.0 & 0.0 & 0.0 & 0.0 & 0.0 & 0.0 \\
\hline \multirow[t]{9}{*}{ Required } & $"$ & $3 \mathrm{~A}$ & 25 & 1.0 & 4.7 & 7.7 & 5.6 & 0.0 & 0.8 & 0.1 & 0.3 \\
\hline & $"$ & $5 \mathrm{~A}$ & 28 & 0.2 & 4.1 & 1.3 & 2.9 & 0.0 & 0.0 & 0.0 & 0.2 \\
\hline & $"$ & $9 \mathrm{~B}$ & 55 & 0.0 & 0.0 & 2.2 & 2.6 & 0.0 & 0.0 & 0.0 & 0.0 \\
\hline & Elk Creek & $1 \mathrm{~A}$ & 44 & 0.4 & 0.0 & 0.1 & 0.1 & 0.4 & 0.0 & 0.0 & 0.1 \\
\hline & $"$ & $1 \mathrm{~B}$ & 54 & 1.4 & 0.6 & 0.1 & 11.9 & 1.4 & 0.6 & 0.0 & 0.3 \\
\hline & $"$ & $2 \mathrm{~A}$ & 53 & 0.0 & 0.0 & 0.0 & 0.2 & 0.0 & 0.1 & 0.0 & 0.0 \\
\hline & $"$ & 28 & 37 & 1.1 & 0.2 & 3.8 & 11.6 & 1.1 & 0.2 & 0.0 & 0.3 \\
\hline & & & \multicolumn{5}{|c|}{ 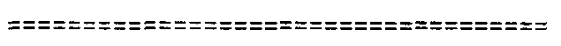 } & \multicolumn{4}{|c|}{ 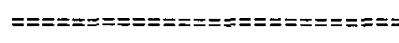 } \\
\hline & Treatment Means: & & 45.6 & 0.7 & 1.4 & 1.8 & 4.3 & 0.3 & 0.2 & 0.0 & 0.1 \\
\hline Control & Knapp $C_{r}$. & $1 A$ & 26 & 23.6 & 7.2 & 10.4 & 11.1 & 1.1 & 0.7 & 3.5 & 3,4 \\
\hline \multirow[t]{8}{*}{ Streams } & Beaver $\mathrm{Cr}$. & $1 \mathrm{~A}$ & 4 & 12.9 & 7.2 & 0.5 & 9.8 & 1.4 & 0.0 & 0.1 & 1.2 \\
\hline & $"$ & $3 B$ & 11 & 10.8 & 28.6 & 5.9 & 26.8 & 1.2 & 2.1 & 0.7 & 2.4 \\
\hline & Cape Horn Cr. & $2 B$ & 20 & 49.0 & 10.7 & 96.8 & 55.1 & 0.2 & 0.0 & 0.0 & 0.0 \\
\hline & $" 1$ & $1 \mathrm{~A}$ & 8 & 34.7 & 14,5 & 39.4 & 40.7 & 0.1 & 0.6 & 0.9 & 4.2 \\
\hline & Sulphur $\mathrm{Cr}$. & $4 \mathrm{~A}$ & 36 & 0.1 & 25.8 & 39.9 & 24.1 & 0.0 & 0.3 & 3.2 & 3.4 \\
\hline & 11 & $4 B$ & 30 & 18.1 & 62.6 & 18.8 & 67.9 & 1.0 & 1.0 & 0.2 & 4.4 \\
\hline & & & \multicolumn{5}{|c|}{ 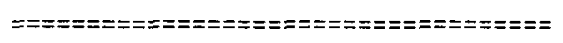 } & \multicolumn{4}{|c|}{ 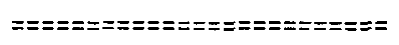 } \\
\hline & Control Means: & & 19.6 & 21.3 & 22.4 & 30.2 & 33.7 & 0.7 & 0.7 & 1.2 & 2.7 \\
\hline
\end{tabular}


PART II

SUBPROJECT II

INTENSIVE EVALUATION AND MONITORING OF CHINOOK SALMON AND STEELHEAD TROUT PRODUCTION, CROOKED RIVER AND UPPER SALMON RIVER SITES

Annual Report 1988

Prepared by

Russell B. Kiefer, Sr. Fishery Research Biologist

And

Katharine A. Forster, Fishery Technician

IDAHO DEPARTMFNT OF FISH AND GANE

Prepared for

U.S. Department of Energy

Bonneville Power Administration

Division of Fish and Wildlife

P.O. Box 3621

Portland, OR 97208

Contract No. DE-AI79-84BP13381

Project 83-7

May 1990 


\section{TABLE OF CONTENTS}

\section{Page}

INTRODUCTION

STUDY SITE DESCRIPTIONS • • • • • • • • • • • • • • • • • • • •

upper Salmon River • • • • • • • • • • • • • • • •

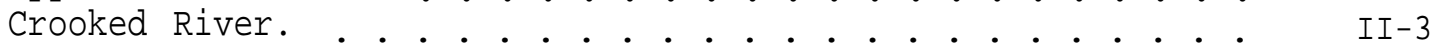

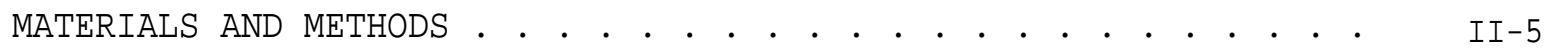

Habitat Evaluation . . . . . . . . . . . . . . . . . II-5

Adult Escapement and Redd Counts . . . • . . . . . . . • II-6

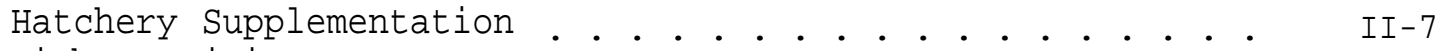

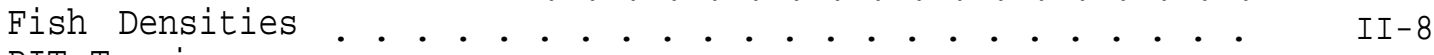

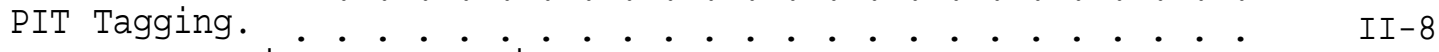

Downstream Migrant Trapping.

UPPER SALMON RIVER RESULTS AND DISCUSSION • • • • • • • • • • • , IIIO

Adult Escapement and Redd Counts . . . . . . . . . . . II-IO

Hatchery Supplementation . . . . . . . . . . . . . . . 10

Fish Density and Physical Habitat Analysis . • . . . . . II-14

PIT Tagging. . . . . . . . . . . . . . . . . . . . . • II-17

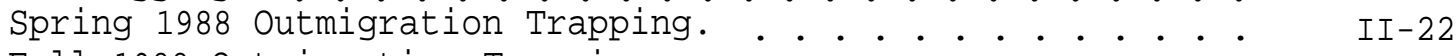

Fall 1988 Outmigration Trapping.

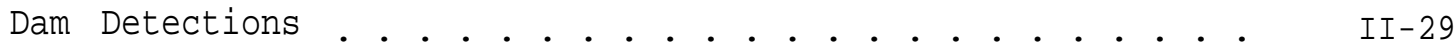

CROOKED RIVER RESULTS AND DISCUSSION •

Adult Escapement and Redd Counts . • . . . . . . . . . . II-35

Hatchery Supplementation . • . . . . • • . . . . • • II-37

Parr Density . • . . . . . • . . . . . • . . . • II-37

PIT Tagging. . • . . . . . . . . . . . . . . . . . . $\quad I I-41$

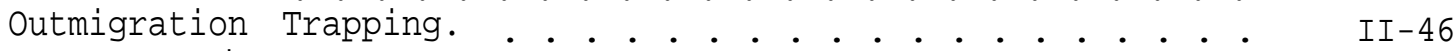

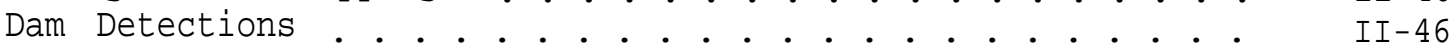

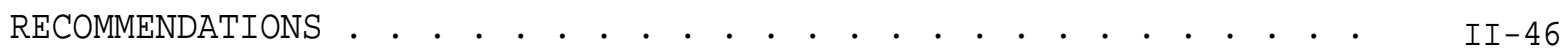

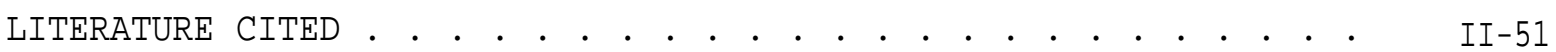




\section{$\underline{\text { Paqe }}$}

Table 1. Adult escapement, redd counts, and estimate of eggs deposited for USR . . . . . . . . . . . . . . II-11

Table 2. USR chinook supplementation, summary by brood year 1984-88. . . . . . . . . . . . . II-12

Table 3. USR steelhead supplementation, summary by brood year 1984-88................. II-12

Table 4. Estimated parr production and survival by outplant method from chinook supplementation evaluation in USR, brood year 1987-88 . . . . . . . .

Table 5. Density (number/100 $\mathrm{m}^{2}$ ) of age-0 chinook in the USR, 1984-1988... . . . . . . . . . . . II-15

Table 6 . Density (number/100 $\mathrm{m}^{2}$ ) of age-1/age-2+ steelhead parr in the USR, 1984-1988 . . . . . . . II-16

Table 7. Egg-to-Parr survival rates for natural chinook in USR.................. . . II-18

Table 8. Collection and PIT tagging mortalities for USR, August 1988 . . . . . . . . . . . . .

Table 9. Twenty-four hour delayed mortality test results for USR.................. II-20

Table 10. Average lengths of PIT-tagged parr from USR . . . . . II-21

Table 11. Fish length and smolt success for USR 1988 . . . . . II-36

Table 12. Percent detection of 1987 PIT-tagged parr by smolt collecting dams, 1988 . . . . . . . . . . II-36

Table 13. Estimated chinook salmon adult escapement, redd counts, and number of eggs deposited for $\mathrm{CR}$. . . . . . . . . . . . . . . .

Table 14. CR chinook supplementation, summary by brood year 1984-88.... . , . . . . . . . II-39

Table 15. CR steelhead supplementation, summary by brood year 1984-88............... . 
Table 16. Density (number/100 $\mathrm{m}^{2}$ ) of age-0 chinook in $\mathrm{CR}$, August 1984-88. . . . . . . . . . . . II-40

Table 17. Density (number/100 $\mathrm{m}^{2}$ ) of age-1/age-2+ steelhead parr for $\mathrm{CR}, 1984-88$. . . . . . . . . . II-42

Table 18. Collection and PIT tagging mortalities for CR, August 1988... . . . . . . . . . . . II-43

Table 19. 1988 twenty-four hour delayed mortality test

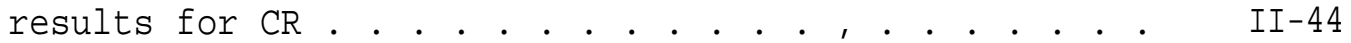

Table 20. 1988 average lengths of PIT-tagged parr from $\mathrm{CR} \cdot 0^{\circ} \cdot{ }^{\circ} \cdot{ }^{\circ} \cdot{ }^{\circ} \cdot 45$

\section{LIST OF FIGURES}

Figure 1. Location of the USR study sections $(\cdot)$. Solid arrows indicate major diversions . . . . . . II-2

Figure 2. Location of the CR study area, pond (o) and river study sections $(\cdot)$, and meadows degraded by dredging (shaded). Arrow indicates trapping facility............... . II-4

Figure 3. Spring 1988 USR run estimates . . . . . . . . . . II-23

Figure 4. Spring 1988 USR chinook run estimate and silldepth . . . . . . . . . . . . . . . . . II-24

Figure 5. Fall 1988 USR run estimates . . . . . . . . . . . . . II-26

Figure 6. Fall 1988 USR chinook run estimate and daily $(10: 00 \mathrm{am})$ stream temperature . . . . . . . II-27

Figure 7. Fall 1988 chinook run estimate and silldepth. . . . . . . . . . . . . . II-28

Figure 8. Spring 1988 travel time for smolts tagged at SWT and detected at LGR dam . . . . . . . . . II-30

Figure 9. Spring 1988 daily number of USR chinook detections at LGR dam and daily chinook run estimates at LGR dam . . . . . . . . . . . II-31 


\section{LIST OF FIGURES (Cont.)}

Page

Figure 10. Spring 1988 daily number of USR steelhead detections at LGR dam and daily total wild/natural steelhead run estimates at $\mathrm{L}$ G R d a m ................

Figure 11. 1988 USR chinook and steelhead detections at LGR dam . . . . . . . . . . . . . . . . II-33

Figure 12. Spring 1988 daily number of USR chinook detections at LGR dam and flows (kcfs) at LGR dam . . . . . . . . . . . . . . . . . II-34

Figure 13. Fall 1988 CR outmigration run estimates . . . . . . II-47

Figure 14. Fall $1988 \mathrm{CR}$ chinook run estimates and daily $(10: 00 \mathrm{am})$ water temperature... . . . . II-48

Figure 15. Fall $1988 \mathrm{CR}$ chinook run estimate and pool depth reading. . . . . . . . . . . . II-49 


\section{INTRODUCTION}

The overall objective of Project $83-7$ is to quantify changes in physical habitat and in chinook salmon oncorhvnchus tshawvtscha and steelhead trout $\underline{0}$. mykiss smolt production relating to Bonneville Power Administration (BPA) funded habitat improvement projects. It has been generally accepted that habitat improvement projects can lead to increased fish production, and in anadromous populations the change in smolt production would be the best measure of a project's effectiveness. The actual increase in smolt production, however, has never been statistically quantified in the field (Buell 1986). A realistic quantitative approach for Idaho is: 1) to estimate parr production attributable to habitat projects through general monitoring; 2) to quantify relationships between spawning escapement, parr production, and smolt production through intensive monitoring in two typical anadromous stream reaches; and 3) to use the determined parr-to-smolt survival rates as a basis for BPA mitigation accounting.

Work began on the intensive monitoring subproject in september 1986. The primary objectives of the intensive monitoring subproject are to determine: 1) smolt production from two typical anadromous stream reaches; 2) parr-to-smolt survival rates for wild and natural chinook and steelhead for BPA habitat project mitigation; 3) the mathematical relationship between spawning escapement, parr production, and smolt production; 4) migration characteristics; 5) the most effective methods of supplementing natural anadromous fish production with hatchery production; 6) habitat rearing potential, potential smolt production, and reproductive potential for the two study streams; and 7) which factors limit wild and natural smolt production.

\section{STUDY SITES}

\section{Upper Salmon River}

The Salmon River originates in the Sawtooth, Smokey, and White Cloud mountains in south central Idaho (Figure 1). The upper Salmon River (USR) study site is located upstream from the Sawtooth Hatchery, at elevations above 1,980 $\mathrm{m}$. Study sections are located throughout the upper basin. The river above Sawtooth Fish Hatchery is a major production area for spring chinook salmon and A-run summer steelhead trout. Resident salmonids in the USR drainage are native rainbow trout, cutthroat trout, bull trout, mountain whitefish, and non-native brook trout (Mallet 1974).

Historically, sockeye salmon existed in all moraine lakes in the Stanley Basin (Everman 1895). An extremely depressed, remnant run of sockeye returns to Redfish Lake, whose outlet enters the Salmon River approximately $2.7 \mathrm{~km}$ downstream from Sawtooth Hatchery. Adult sockeye occasionally have been seen in Alturas Lake Creek (ALC) (K. Ball, Idaho Department of Fish and Game (IDFG),

personal communication), but an irrigation diversion that completely dewaters 


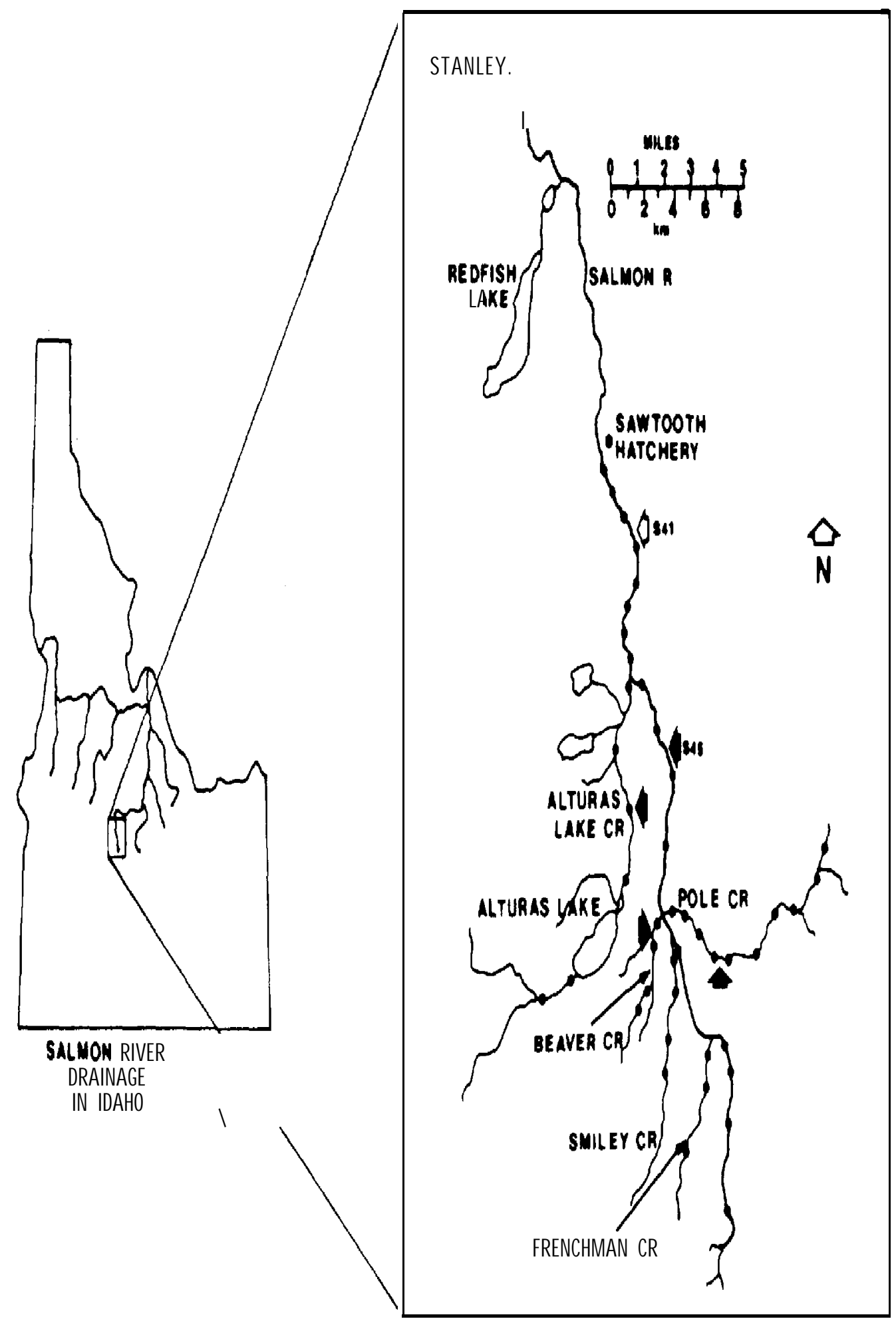

Figure 1. Location of the USR study area and study sections $(\cdot)$. Solid arrow indicates major irrigation diversions, 
the creek every summer makes adult passage to the lake unlikely (Bowles and Cochnauer 1984). No other sockeye runs are known to exist in the Salmon River drainage.

Nearly pristine water quality and an abundance of high quality spawning gravel and rearing habitat is present throughout much of the upper basin. Water flows at the Sawtooth Hatchery range from lows of 1.73-3.46 cms from July through April, to highs of 11.21-23.31 cms during May and June.

Livestock grazing and hay production are predominant uses of private land throughout the USR basin. Grazing in riparian zones has degraded aquatic habitat in localized areas. Water diversions from the river and tributaries have impaired the potential for production of chinook and steelhead in some of the USR drainage.

The Busterback (S45) diversion between ALC and Pole Creek completely dewaters the river for approximately $3 \mathrm{~km}$ from July through september in an average flow year. Flow diversions from tributary streams vary from partial to complete dewatering. Conversion from flood to overhead sprinkler irrigation has decreased the withdrawal of water from Pole Creek since 1982. BPA funded the construction of a fish screen for the irrigation diversion on Pole Creek in 19831984. Steelhead fry have been outplanted into upper Pole Creek every year since 1985 (IDFG, unpublished data). This project's outplant of 34 chinook adults in 1988 was the first time chinook have been available for reintroduction into Pole Creek.

The Sawtooth Fish Hatchery was constructed in cooperation with the U.S. Fish and Wildlife Service and the U.S. Army Corps of Engineers through the Lower Snake River Compensation Plan. The hatchery program involves trapping adult chinook and steelhead and releasing smolts and other life stages. The hatchery is designed to produce 2.4 million chinook smolts per year. Steelhead eyed eggs are sent to other facilities for rearing, and the smolts are transported back to Sawtooth Hatchery for release. Approximately 700,000 steelhead smolts were released from the hatchery in 1986 ( $T$. Rogers, IDFG, personal communication). At least 33\% of the adult chinook and steelhead entering the trap are released upstream of the hatchery to spawn naturally.

\section{Crooked River}

Crooked River originates at an elevation of $2,070 \mathrm{~m}$ in the Clearwater Mountains within the Nez Perce National Forest and enters the South Fork Clearwater River at river kilometer 94 at an elevation of 1,140 m (Figure 2). The study site includes the entire Crooked River (CR) drainage. Chinook and steelhead runs were eliminated historically by the construction of Harpster Dam on the South Fork Clearwater River in 1927. Spring chinook and B-run summer steelhead were reestablished in CR following removal of the dam in 1962. Resident salmonids in the CR drainage are mountain whitefish, rainbow trout, bull trout, and cutthroat trout (Petrosky and Holubetz 1986). 


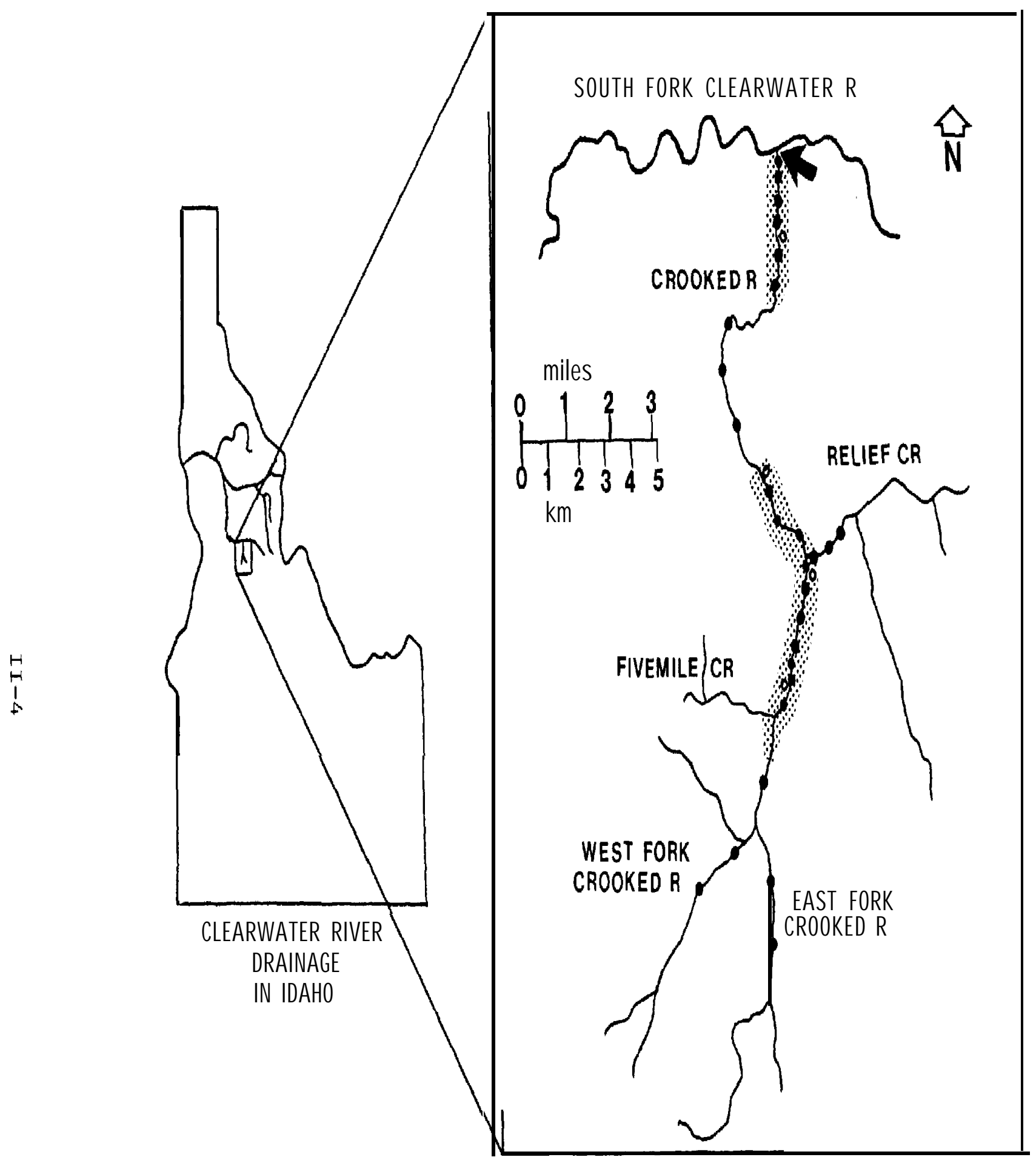

Figure 2. Location of the CR study area, pond $(0)$ and river $(*)$ study sections, and meadows degraded by dredging (shaded), Arrow indicates location of trapping facility. 
Dredge mining activities during the 1950 s severely degraded habitat within the two meadow reaches of the stream. In the upstream meadow the stream was forced to the outside of the floodplain, resulting in a straight, high gradient channel. In the lower meadow dredge, tailings have forced the stream into long meanders with many ponds and sloughs. During runoff, juvenile trout and salmon use some of these ponds, but are trapped as flow recedes. Water flows on CR were measured from May to September and ranged from 152-7 cms (Mann and Von Linder 1986).

Fish density and habitat surveys were initiated in 1984 by IDFG and the Intermountain Forest and Range Experiment Station, U.S. Forest Service (USFS), Boise, Idaho. Petrosky and Holubetz (1985) found that densities of juvenile chinook and steelhead in the two meadow reaches were relatively lower than those in other Idaho streams. Densities of fish in the few pools and high velocity sections were similar, indicating the lack of a relationship between juvenile density and habitat type. Since chinook parr generally prefer pool habitat over high velocity sections, this lack of a relationship between juvenile density and habitat type indicates that the upper meadow reach was underseeded in 1984.

In 1984, the USFS, with BPA funds, placed a series of log structures, rock and boulder deflectors, organic debris structures, and loose rock weirs in the upper meadow in an effort to compensate for stream gradient and increase the pool-to-riffle ratio. In addition, banks were stabilized and revegetated, an off-channel pond was connected with a side channel, and a culvert blocking adult passage was removed (Hair and Stowell 1986). Recent efforts have concentrated on connecting additional ponds in the dredge tailings to the main channel and developing side channels to provide continuous water supply during low flow periods.

\section{MATERIALS AND METHODS}

\section{Habitat Evaluation}

Project personnel conducted physical habitat surveys on 22 sections on $\mathrm{CR}$, and two sections on the USR using the Idaho ocular method (Petrosky and Holubetz 1987). USFS personnel (BPA project 84-24) also used this method for 26 study sites in the USR in 1988.

The Idaho ocular method was derived from Platts et al. (1983). In this method, transects were established at $10 \mathrm{~m}$ intervals within each study section, and stream width was measured at each transect. Depth, velocity, substrate composition, embeddedness, and habitat type (ie. pool, run, riffle, pocketwater, or backwater) as described by Shepard (1983) were measured or determined at the one-quarter, one-half, and three-quarter points of each stream transect. Proportions of sand (0-0.5 cm diameter), gravel $(>0.5-7.4 \mathrm{~cm})$, rubble $(>7.5-30.4$ $\mathrm{cm})$, boulder $(>\mathbf{3 0 . 4} \mathrm{cm})$, and bedrock that comprise the substrate were estimated visually. Embeddedness (the proportion of surface area of gravel, rubble, and boulder surrounded by sand) was classified as 0\%, 0-5\%, 5-25\%, 25-50\%, 50-75\%, 75-100\%, and 100\%. Stream gradient was measured with a surveyor's transit and stadia rod as the elevation difference between the upper and lower section 
boundaries divided by the section length. Stream channel type was classified according to Rosgen (1985). All sections were flagged and photographed for future repeated measurements.

Project data for 1987-88 have been entered into the IDFG physical habitat database for future analysis. The management of this database is handled by Subproject I personnel.

\section{Adult Escapement and Redd Counts}

Actual escapements for chinook and steelhead in the USR were obtained from Sawtooth Hatchery records. Except for the possibility of a small percentage of early and late fish in each of the runs, the entire escapement above the hatchery weir consisted of fish that were collected in the hatchery trap and then released upstream to spawn naturally. No actual escapements will be available for CR until the trapping facility is completed there in the summer of 1990.

Chinook trend redd counts were conducted by the respective regional fisheries personnel (Hall-Griswold 1988). The trend count for the USR was a oneday peak count by helicopter during the first week of September that covered the entire current spawning area. The trend count for $\mathrm{CR}$ is a one-day peak count by helicopter between Relief Creek and Five Mile Creek during the first week in september.

Total chinook ground counts were conducted in both the USR and CR study areas to determine natural spawning. Counts were done using guidelines identified by IDFG personnel (Redd Count Manual 1987). The entire probable spawning area was walked to count redds and actively spawning fish. All encountered carcasses were measured (fork length) and cut open to confirm sex and completeness of spawning. The USR ground count was conducted from Sawtooth Hatchery to the headwaters on August 31 and September 1, 1988. On CR, the ground count was conducted from the mouth to the forks on September 8, 1988.

Ground redd counts were attempted in both study areas to evaluate the natural spawning of steelhead trout. However, high turbid water prevented us from obtaining useful counts in either area.

The number of female chinook and steelhead spawning in the USR was estimated as the number of females released above the weir multiplied by the percent of pre-spawning survival observed at the Sawtooth Hatchery 10.95 for chinook; 0.98 for steelhead). Egg deposition was estimated as the number of female spawners multiplied by the average fecundity $(5,600$ for chinook; 5,000 for steelhead). In $\mathrm{CR}$ the number of female chinook spawners was estimated assuming approximately one redd per female as observed in the USR. Chinook fecundity for CR $(4,200)$ was based on estimates from the nearby Red River trapping facility. 


\section{Hatchery Sumlementation}

The experimental design for chinook supplementation evaluation for the USR identified eight separate strata so that two replicates of four supplementation methods could be evaluated. Supplementation evaluation efforts in the USR currently concentrate on chinook for brood year 1987 because of their critical status relative to A-run natural steelhead. The life stages outplanted and their respective strata were: adults into Frenchman Creek and upper Pole Creek; eyed eggs into Beaver Creek and upper Alturas Lake Creek; fry into lower Pole Creek and Smiley Creek; and parr into the Salmon River headwaters and lower Alturas Lake Creek.

Annual seeding levels for supplementation were selected based upon the availability of chinook adults and the levels needed for evaluation. Numbers of eyed eggs, fry and fall released parr were equivalent to the estimated egg deposition of the outplanted adults times the estimated survival in the hatchery to each respective life stage. We evaluated outplant success as survival from green egg to parr and smolt stages. We estimated total parr abundance in July by stratified sampling (three strata, six sections) ranging from $1 \mathrm{~km}$ above to $2 \mathrm{~km}$ below the outplant site.

Fifteen pair of adult chinook were released into Frenchman Creek at study section 2-A during August 28-September 6, 1988. The release site was located within a grazing enclosure that also was sampled for sediment monitoring (Torquemada and Platts 1988). No cattle were in the enclosure while the chinook were spawning. A total of 19 male and 15 female adult chinook were released into Pole Creek at study section 3-B during August 28-September 6, 1988. The Pole Creek release site was located within a meadow subjected to heavy sheep grazing. No sheep were in the meadow while the adults were spawning. Picket weirs prevented the fish from moving above or below the release sites. We monitored spawning activity on alternate days. Water temperatures were measured to predict emergence dates. Carcasses were cut open to confirm sex and determine completeness of spawning, and fork length was measured.

A total of 28,000 chinook eyed eggs were buried in artificial redds into both Beaver Creek and ALC during October 3-4, 1988. Redd design was based on findings by Chapman (1988). The site selected for outplant on Beaver Creek was in stratum 2, $4.5 \mathrm{~km}$ above the mouth. The outplant site for ALC was above Alturas Lake at study site 3-B. In both study sites, the eggs were buried in 14 artificial redds (2,000 eggs/redd) according to the directions of white (1980). Due to poor success with eyed egg outplants in 1987, we only outplanted the number of eggs that five females would have produced ( 5 females X 5,600 eggs/female $=28,000$ eggs). Fecundity was based on the 1981-84 average at Sawtooth Hatchery.

On May 25, 1988, chinook fry were outplanted in Smiley Creek at study site 2-A and in Pole Creek at study site 2-B. A total of 24,000 fry were released into each site.

On October 12, 1988, a group of 21,500 chinook parr were released into the Salmon River at study site 10-A and on October 11, 1988 into lower ALC at the 
second bridge, $5 \mathrm{~km}$ above the mouth. Before the release, we PIT-tagged a representative sample of 300 parr from each of these groups to estimate survival. The parr were held in hatchery raceways for two weeks after tagging to determine delayed mortality and check for lost tags.

\section{Fish Densities}

Fish abundance by species and age-class was estimated by snorkeling through established sections (Petrosky and Holubetz 1989). Surveys were conducted in 26 sections on CR during July 7-10, 1988, and in 72 sections on the USR during July 18-24, 1988. Total abundance of steelhead and chinook parr were estimated by stratified sampling (Schaeffer et al. 1979). Bounds on the error of estimation were expressed as $\pm 2 \mathrm{SE}$.

\section{PIT Tagging}

Chinook and steelhead parr were PIT-tagged in their summer rearing areas during August 15-24, 1988 for the USR and August 2-9, 1988 on CR. National Marine Fisheries Service (NMFS) personnel cooperated in chinook tagging in both study areas.

We collected fish for PIT tagging with a Smith-Root model 12 electrofisher or seine, depending on which method was most suitable for each particular site and species. Seines were primarily used to sample pools, and the electrofisher was used to sample riffles.

The electrofisher was operated with the following configuration and settings: $\quad 30.5 \mathrm{~cm}$ diameter anode ring on a $2 \mathrm{~m}$ pole, $2.4 \mathrm{~m}$ rattail cathode, voltage setting between 200 and $400 \mathrm{~V}$, and pulse rates of $90 / \mathrm{sec}$ when fishing primarily for chinook and $30 / \mathbf{s e c}$ for steelhead. Conductivity in the USR drainage ranges from 37-218 $\mu$ mhos/cm (Emmett 1975). The conductivity on CR ranges from 35-50 $\mu$ mhos/cm (Mann and Von Lindern 1987). We observed that nylon netting tied completely around the anode ring reduced the incidence of electrical burn marks and fish mortality without a reduction of capture effectiveness.

Additional parr were PIT-tagged during the outmigration trapping operations. We anesthetized fish with MS-222 and injected PIT tags into the body cavity using a 12-gauge hypodermic needle and modified syringe. The needle was oriented anteriorly to posteriorly and inserted just off the mid-ventral line, about $1 / 4$ of the distance between the tip of the pectoral fin and the pelvic girdle. Immediately after the needle entered the body cavity it was rotated so the bevel of the needle made contact with the inner surface of the body wall. The tag was then inserted. After tagging, tag presence was confirmed using a hand-held detection/decoding device (Prentice et al. 1986). NMFS has found that once a functional tag has been successfully implanted in a fish, the tag failure rate has been less than 1\%. Fork length was measured to the nearest millimeter on all parr that were PIT-tagged. Fish weight was measured to the nearest tenth of a gram on most of the fish tagged using a Port-0-Gram balance. Perforated 
$5 \times 4 \mathrm{~m}$ plastic tote boxes were used to hold fish before being tagged, during recovery, and for $24-\mathrm{h}$ delayed-mortality tests.

The hand-held PIT tag detector was used to detect and send the tag codes to a Tandy 102 portable micro-computer. The micro-computer used a BASIC program supplied by NMFS to organize the tag codes and associated data into tag files. These PIT tag data files were downloaded daily to a COMPAQ personal computer for storage and printing.

We conducted tests on chinook and steelhead in both study areas to determine delayed mortality or tag loss. Fish were held 24 hours in the perforated plastic tote boxes in the stream sections they were tagged in. After the 24-hour holding period, all fish were scanned to confirm tag presence. Tags were retrieved from all tagging mortalities.

In the USR, five delayed mortality tests were conducted on chinook and steelhead that we collected by either electrofishing or seining. Electrofishing samples were from Pole Creek at study section I-B, Alturas Lake Creek at study section I-C, and on the main stem of the Salmon River in stratum 9. Seining samples were from Frenchman Creek in stratum 2, and in the Salmon River at study section $7-\mathrm{A}$.

In $\mathrm{CR}$, four delayed mortality tests were conducted on chinook and steelhead with the same methods used in the USR. Delayed mortality tests were done on chinook and steelhead collected by electrofishing in stratum 1 at study site sill

Log B, and on Relief Creek at study site 1. Delayed mortality tests for seined chinook and steelhead were conducted in stratum 2 at pond $U$, and in stratum 3 at the Natural 3 study section.

\section{Downstream Miqrant Trapping}

We monitored the outmigration of juvenile anadromous fish in the USR with a floating scoop trap equipped with a $1.0 \mathrm{~m}$ wide inclined traveling screen (Midwest Fabrications Inc., Corvallis, Oregon). The trap was attached below the weir at the Sawtooth Hatchery weir. Water was funneled to the trap from a 3.1 $\mathrm{m}$ wide bay of the weir and a picket weir covered with $6 \mathrm{~mm}$ hardware cloth. To evaluate the spring 1988 outmigration, the trap was operated from March 18-June 16. The trap was operated from August 16-October 31 to evaluate fall outmigration. A modified Krey-Meekin trap was operated at the Sawtooth Hatchery intake structure from March 19-April 7 to collect additional smolts for tagging. This trap was taken out of operation early (April 7) due to high water.

To evaluate the 1988 fall outmigration on $\mathrm{CR}$, the modified Krey-Meekin trap was used due to a construction delay of two scoop traps. It operated from August 16-November 2. A rock weir was installed by the USFS to funnel fish to the trap. Trap efficiency was estimated by mark and recapture of PIT-tagged fish released upstream. 


\section{UPPER SAIMON RIVER \\ RESULTS AND DISCUSSION}

Adult Escapement and Redd Counts

Accurate female and total escapement numbers have been available since 1985 for the USR with the operation of the Sawtooth Fish Hatchery weir and adult trap. Total egg deposition for both chinook and steelhead were calculated in 1984-88 using known female escapement and fecundity estimates from Sawtooth Hatchery. Known escapements will be correlated with redd counts for chinook and attempted for steelhead.

Chinook redd counts were conducted in 1988 on the ground and by helicopter over the entire probable spawning area of the USR. A one-pass ground count was conducted during August 30-September 1. When chinook redds were discovered by helicopter above the ALC diversion, outside the "probable spawning area," we conducted a ground count in this stratum on september 13. The helicopter count of the USR was conducted by the IDFG Region 6 Fishery Manager on september 7. A total of 261 chinook redds were observed during ground counts, compared to the helicopter count of 76 (Table l). The ground and helicopter counts represented 95\% and 28\% of the known female escapement, respectively. Several (approximately 15) redds were observed from the ground that would not be etectable from a helicopter because of recent sedimentation of the redds caused by late summer sheep grazing. Other reasons for the discrepancy between ground and helicopter counts might be that from the air multiple redds were counted as singles, and overhanging vegetation hid some of the redds. Ground and helicopter redd counts will be conducted for two more years in the USR to develop a correction factor for helicopter counts.

Steelhead redd counts were not conducted on the USR in 1988 because of difficulties in conducting redd counts during spring run-off and because accurate escapement numbers were available from Sawtooth Fish Hatchery. In 1989 a helicopter count will be conducted to determine the usefulness of aerial steelhead redd counts.

\section{Hatchery Supplementation}

Hatchery supplementation data in the USR for brood years 1984-88 ar summarized in Tables 2 and 3. Egg-to-Parr survival rates by outplant methr' brood year 1987 were estimated to be: adults $32 \%$; eyed eggs $0.4 \%$; and fiy $16 \%$ (Table 4). Parr-to-smolt survival rates from these outplants will be calculated during winter 1990. Egg-to-Parr survival rate estimates were based on single samples in an atypical, low flow year. However, survival from the fry and adult outplants were similar to those estimated by scully et al. (1990). We believe that the poor survival from the eyed-egg outplant was primarily a result of the artificial redd design. The artificial redds were constructed level with the 
Table 1. Adult escapement, redd counts, and estimate of eggs deposited for USR.

\begin{tabular}{|c|c|c|c|c|c|}
\hline & & & Chinook & lmon & \\
\hline & 1984 & 1985 & Brood & 1987 & 1988 \\
\hline Total escapement & 205 & 625 & 876 & 506 & 552 \\
\hline Female escapement & $65^{a}$ & 180 & 248 & 252 & 275 \\
\hline Helicopter count & 74 & 83 & 105 & 124 & 76 \\
\hline Ground count & & & & & 261 \\
\hline Eggs/female $e^{b}$ & 6,017 & 4,530 & 5,156 & 5,399 & 5,653 \\
\hline $\begin{array}{l}\text { Estimated number } \\
\text { eggs deposited }\end{array}$ & 391,105 & 815,400 & $1,278,688$ & $1,360,548$ & $1,554,575$ \\
\hline & & & Steelhead & rout & \\
\hline & 1984 & 1985 & 1986 & 1987 & 1988 \\
\hline Total escapement & & 206 & 1,056 & 979 & 365 \\
\hline Female escapement & $22^{a}$ & 92 & 322 & 383 & 136 \\
\hline Eggs/female $e^{b}$ & 3,969 & 5,640 & 4,468 & 4,854 & 5,069 \\
\hline $\begin{array}{l}\text { Estimated number } \\
\text { eggs deposited }\end{array}$ & 87,318 & 518,880 & $1,438,696$ & $1,859,082$ & 689,384 \\
\hline
\end{tabular}

${ }^{a}$ In 1984, a temporary weir was used and escapement was probably greater.

Dumber is average eggs/female observed at Sawtooth Fish Hatchery. 
Table 2. Upper Salmon River chinook supplementation, summary by brood year 1984-88.

\begin{tabular}{|c|c|c|c|c|c|}
\hline & 700 & & rood & 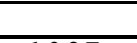 & 70 \\
\hline & & & & & \\
\hline Adult females & 0 & 19 & 0 & 6 & 30 \\
\hline Eyed eggs & 0 & 0 & 0 & 28,000 & 56,530 \\
\hline Fry & 0 & 0 & 0 & 48,000 & 275,000 \\
\hline Fall parr & 0 & 0 & 0 & 43,000 & 0 \\
\hline Smolts & 0 & 0 & 0 & 0 & 0 \\
\hline
\end{tabular}

Table 3. Upper Salmon River steelhead supplementation, summary by brood year 1984-88.

\begin{tabular}{lrrrrr}
\hline & \multicolumn{5}{c}{ Brood year } \\
\cline { 2 - 6 } Adult females & 1984 & 1985 & 1986 & 1987 & 1988 \\
Fry & 1,271 & 0 & 1,056 & 0 & 83 \\
Fall parr & 317,500 & $\mathbf{1 , 2 7 6 , 5 0 1}$ & 832,414 & 678,680 & 537,700 \\
Smolts & 0 & 0 & 0 & 0 & 0 \\
& 0 & 0 & 0 & 0 & 0 \\
\hline
\end{tabular}


Table 4. Estimated parr production and survival by outplant method from chinook supplementation evaluation in USR, brood year 1987-88.

\begin{tabular}{|c|c|c|c|}
\hline \multirow{2}{*}{$\begin{array}{l}\text { Outplant } \\
\text { method }\end{array}$} & \multirow[b]{2}{*}{ Population parameter } & \multicolumn{2}{|c|}{ Brood year } \\
\hline & & 1987 & 1988 \\
\hline Adult & $\begin{array}{l}\text { Females outplanted } \\
\text { Egg deposition } \\
\text { Parr production } \\
\text { Egg-to-Parr survival }\left(\frac{\mathbf{q}}{\mathbf{s}}\right)\end{array}$ & $\begin{array}{r}6^{\mathbf{a}} \\
26,995 \\
8,625 \\
32.0\end{array}$ & $\begin{array}{r}30 \\
169,590\end{array}$ \\
\hline Eyed-egg & $\begin{array}{l}\text { Egg deposition } \\
\text { Parr production } \\
\text { Egg-to-Parr survival (q) }\end{array}$ & $\begin{array}{r}28,000 \\
109 \\
0.4\end{array}$ & 56,530 \\
\hline Fry ${ }^{b}$ & $\begin{array}{l}\text { Hatchery egg requirement } \\
\text { Fry outplanted } \\
\text { Parr production } \\
\text { Egg-to-Parr survival ( }(\mathbf{6})\end{array}$ & $\begin{array}{r}28,000 \\
24,000 \\
4,525 \\
16.2\end{array}$ & 169,590 \\
\hline
\end{tabular}

One of the six females died before spawning and was not included in the calculations.

Most of the fry outplanted into lower Pole Creek outmigrated immediately after the outplant and are not included in the egg-to-parr survival estimates. 
surrounding substrate without an elevated tailspill. According to Chapman (1988), the tailspill helps to create a current flow down through the egg pocket to flush metabolic wastes and maintain high oxygen levels for optimum egg-tofry survival.

The fry outplant into lower Pole creek was excluded as atypical for the brood year 1987 calculations. Many of these fish outmigrated from Pole Creek immediately after the outplant (Gary Gadwa, IDFG personal communication). This apparently was in response to extremely low flows below the Pole Creek diversion. Since most of these fish did not stay in the outplant area, we could not estimate the parr population and egg-to-parr survival.

\section{Fish Density and Physical Habitat Analysis}

Project data for 1985 through 1988 have been entered into the IDFG fish density and physical habitat data bases. The management of these databases is being handled by Subproject I personnel. During winter 1990, we will begin to correlate fish density and physical habitat data for the USR.

The densities of age-0 chinook changed during 1984-88 (Table 5). Most significant was a general reduction of chinook parr densities above the 545 diversion during the low flow years 1987-88. Natural populations were reduced beginning with brood year 1984 (1985 density) by trapping adults at Sawtooth Hatchery. Aerial redd counts declined from 161 in 1983 to 71 in 1984. During low flow years, the 545 diversion completely dewatered the Salmon River for approximately $3 \mathrm{~km}$ from mid-July through September, and only early returning adult chinook could spawn above the diversion. The higher chinook parr densities observed in stratum 7 of the Salmon River and stratum 1 of ALC indicate that adult chinook stacked up and spawned below these major diversions.

A reduction in steelhead parr densities occurred in 1984-88, primarily in the areas above the 545 diversion (Table 6). The diversion may be the major cause in the reduction of the steelhead parr population observed during the period.

Estimates for total parr abundance in the USR during summer 1988 were: age-0 chinook $=88,103 \pm 43,772 ;$ age-1 steelhead $=5,325 \pm 2,006$; and age-2+ steelhead $=2,090 \pm 1,531$.

The 1988 chinook age-0 population estimate was slightly higher than in two recent years in which estimates were made: $1985(73,548)$ and $1987(65,739)$ (Kiefer and Apperson 1988). Populations all three years were reduced by trapping adults for Sawtooth Hatchery brood stock. The first year that Sawtooth Hatchery supplemented chinook back into the USR was 1988. An estimated total of 17,784 chinook parr were the result of supplementation in 1988 (Table 4). This estimate assumes that the fry that outmigrated from Pole Creek survived at the same rate as those outplanted into Smiley Creek. 
Table 5. Density (number/100 $\mathrm{m}^{2}$ ) of age-0 chinook in the USR, 1984-1988.

\begin{tabular}{|c|c|c|c|c|c|}
\hline Stratum & 1984 & 1985 & 1986 & 1987 & 1988 \\
\hline $\begin{array}{c}\text { Salmon River } \\
3,4 \\
5,6 \\
7 \\
8 \\
9 \\
10\end{array}$ & $\begin{array}{c}- \\
- \\
67.95 \\
55.15 \\
- \\
-\end{array}$ & $\begin{array}{r}15.97 \\
2.27 \\
14.00 \\
1.30 \\
8.40 \\
3.55\end{array}$ & $\begin{array}{l}10.95 \\
12.25\end{array}$ & $\begin{array}{r}7.00 \\
0.28 \\
20.25 \\
10.33 \\
7.42 \\
0.11\end{array}$ & $\begin{array}{r}13.80 \\
4.10 \\
13.26 \\
3.86 \\
1.44 \\
0\end{array}$ \\
\hline $\begin{array}{l}\text { Salmon River } \\
\text { side channels } \\
3,4 \\
5,6 \\
7,9,10\end{array}$ & $\begin{array}{l}- \\
\overline{-} \\
-\end{array}$ & $\begin{array}{r}14.20 \\
0.35 \\
0.50 \\
0.25\end{array}$ & & & $\begin{array}{r}16.00 \\
17.93 \\
16.12 \\
6.75\end{array}$ \\
\hline $\begin{array}{c}\text { Pole Creek } \\
1 \\
2 \\
3 \\
\mathbf{4} \\
5\end{array}$ & $\begin{array}{c}30 . \\
0.20 \\
- \\
-\end{array}$ & $\begin{array}{l}0 \\
0 \\
0 \\
0 \\
0\end{array}$ & 0.15 & $\begin{array}{c}25.73 \\
2.89 \\
0 \\
0 \\
0\end{array}$ & $\begin{array}{l}1.95 \\
4.25 \\
0.12 \\
0 \\
0\end{array}$ \\
\hline $\begin{array}{l}\text { Alturas Lake Creek } \\
\quad 1 \\
\quad 2 \\
3\end{array}$ & $\begin{array}{r}47.23 \\
3.46 \\
0.65\end{array}$ & $\begin{array}{c}12.50 \\
0\end{array}$ & 0.05 & $\begin{array}{r}18.34 \\
0.60 \\
0.06\end{array}$ & $\begin{array}{l}8.64 \\
0.91 \\
0\end{array}$ \\
\hline $\begin{array}{c}\text { Smiley Creek } \\
\frac{1}{2}\end{array}$ & - & $\begin{array}{l}0.10 \\
1.65\end{array}$ & & $\begin{array}{r}35.17 \\
1.10\end{array}$ & $\begin{array}{r}6.94 \\
13.50\end{array}$ \\
\hline $\begin{array}{c}\text { Beaver Creek } \\
1 \\
2\end{array}$ & - & $\begin{array}{l}0.15 \\
0\end{array}$ & & & $\begin{array}{l}2.12 \\
0.39\end{array}$ \\
\hline $\begin{array}{l}\text { Frenchman Creek } \\
\quad 1 \\
2\end{array}$ & - & & & $\begin{array}{l}0 \\
0\end{array}$ & $\begin{array}{r}0.61 \\
41.39\end{array}$ \\
\hline
\end{tabular}



Table 6. Density (number/100 $\mathrm{m}^{2}$ ) of age-1/age-2+ steelhead parr in the
USR, 1984-1988.

\begin{tabular}{|c|c|c|c|c|c|}
\hline $\begin{array}{l}\text { Stream, } \\
\text { Stratum }\end{array}$ & 1984 & 1985 & 1986 & 1987 & 1988 \\
\hline 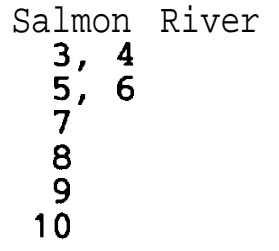 & $\begin{array}{l}\overline{0} \\
0.35 / 0.47 \\
0.17 / 0.77 \\
-\end{array}$ & $\begin{array}{l}0.62 / 0.33 \\
0.20 / 0.17 \\
0.20 / 0.80 \\
0.45 / 0.05 \\
4.20 / 0.20 \\
2.15 / 3.30\end{array}$ & $\begin{array}{l}\overline{-} \\
\overline{0} .35^{\mathrm{a}} \\
0.90^{\mathrm{a}} \\
\overline{-}\end{array}$ & $\begin{array}{l}0.05 / 0.02 \\
0.01 / 0.02 \\
0.72 / 0.00 \\
0.39 / 0.22 \\
8.51 / 2.09 \\
7.27 / 2.37\end{array}$ & $\begin{array}{l}0.20 / 0.08 \\
0.07 / 0.05 \\
0.37 / 0.12 \\
0.38 / 0.11 \\
2.75 / 0.80 \\
3.51 / 2.98\end{array}$ \\
\hline $\begin{array}{l}\text { Salmon River } \\
\text { side channel } \\
3,4 \\
5,6 \\
\mathbf{7}, \\
\mathbf{8}, 9,10\end{array}$ & $\begin{array}{l}- \\
- \\
-\end{array}$ & $\begin{array}{l}2.62 / 0.72 \\
0 / 0 \\
0.60 / 0.10 \\
0 / 0\end{array}$ & - & & $\begin{array}{l}0.56 / 0 \\
0 / 0 \\
0 / 0 \\
0.25 / 0\end{array}$ \\
\hline $\begin{array}{c}\text { Pole } \\
1 \\
2 \\
3 \\
4 \\
4 \\
5\end{array}$ & $\begin{array}{l}\overline{0} / 0.41 \\
0 / 0 \\
- \\
-\end{array}$ & $\begin{array}{l}0.10 / 0.15 \\
1.25 / 0.35 \\
0 / 0 \\
2.90 / 0.10 \\
0 / 0\end{array}$ & $\begin{array}{l}\overline{1} .95^{\mathrm{a}} \\
0.10^{\mathrm{a}} \\
\overline{-} \\
-\end{array}$ & $\begin{array}{l}2.98 / 1.16 \\
5.11 / 1.60 \\
0 / 0.13 \\
1.33 / 1.33 \\
0 / 0.13\end{array}$ & $\begin{array}{l}2.05 / 0.59 \\
0 / 0 \\
0 / 0 \\
4.75 / 0.50 \\
0 / 0.73\end{array}$ \\
\hline $\begin{array}{l}\text { Alturas Lake } \\
\text { Creek } \\
\quad 1 \\
2 \\
3\end{array}$ & $\begin{array}{l}0 / 0.54 \\
0 / 0.11 \\
0 / 0\end{array}$ & $\begin{array}{l}0.70 / 0.10 \\
0.05 / 0\end{array}$ & $\begin{array}{l}\overline{-} \\
\overline{0}^{a}\end{array}$ & $\begin{array}{l}0.83 / 0.03 \\
0.90 / 0.47 \\
0 / 0\end{array}$ & $\begin{array}{l}0.58 / 0.05 \\
0.38 / 0.31 \\
0.12 / 0.12\end{array}$ \\
\hline $\begin{array}{cc}\text { Smiley } & \text { Creek } \\
\mathbf{1} & \\
\mathbf{2} & \end{array}$ & - & $\begin{array}{l}0 / 0 \\
0.15 / 0.10\end{array}$ & - & $\begin{array}{l}0.18 / 0.56 \\
0 / 0.05\end{array}$ & $\begin{array}{l}\circ / \circ \\
0.16 / 0.05\end{array}$ \\
\hline $\begin{array}{l}\text { Beaver Creek } \\
1 \\
2\end{array}$ & - & $\begin{array}{l}0.30 / 0.15 \\
0 / 0\end{array}$ & - & & $\begin{array}{l}0.48 / 0 \\
0.20 / 0.02\end{array}$ \\
\hline \multicolumn{6}{|l|}{$\begin{array}{l}\text { Frenchman } \\
\text { Creek }\end{array}$} \\
\hline $\begin{array}{l}1 \\
2\end{array}$ & - & - & $\overline{-}$ & $\begin{array}{l}1.79 / 2.23 \\
0.00 / 0.00\end{array}$ & $\begin{array}{l}0 / 0.61 \\
0.11 / 0.11\end{array}$ \\
\hline
\end{tabular}

asteelhead age-2+ and age-1 data were combined in 1986. 
Egg-to-Parr survival rates were estimated for naturally produced chinook in three of the past four years in the USR (Table 7). Estimated egg-to-parr survival rate for brood year 1984 (18.8\%) was significantly higher than for brood year 1986 (5.1\%) and brood year 1987 (5.2\%). The brood year 1984 results were probably inflated by uncounted adults getting through the temporary weir used that year. The survival rates for brood years 1986 and 1987 were similar and significantly lower than those calculated for the 1987 Frenchman Creek adult outplant (Table 4) and for similar Idaho streams (Scully et al. 1990). Possible explanations for the low survival include unusually low flows (winter and summer) for brood years 1986-87, habitat quality problems below the S45 diversion and ALC diversion, and spring outmigration of fry. We have observed large numbers of chinook fry outmigrating from the USR during trapping operations from March to May, 1987-88. The magnitude of this outmigration and contributions of this segment of the population will be investigated by the University of Idaho through subcontract beginning spring 1990.

The steelhead parr population estimate in 1988 (7,325 age-1 + and -2+ combined) showed a drastic reductioncomparedto $1985(12,579)$ and $1987(20,132)$. Reasons for this drop are not apparent from either the steelhead escapement or supplementation numbers (Table 1,3$)$. These data indicate that the decrease occurred in the egg-to-parr survival rate, and/or fry outmigration increased without a subsequent return of parr to the study area. There are indications that the Sawtooth Hatchery weir is a barrier to upstream migrating parr that outmigrated in the fall to overwinter downstream. In addition, the estimated survival rate based on parr population estimates for brood year 1986 steelhead age-1 to age-2+ was unexpectedly low (14.6\%). This low survival rate probably resulted from one or a combination of the following factors: high angling mortality, high mortality caused by the $S 45$ diversion $167 \%$ of steelhead parr were found above the diversion), poor genetic match of Snake River A-run fish to high elevation streams, and an upstream migration barrier at the Sawtooth Hatchery Weir that potentially restricted the return of steelhead parr that had overwintered below the weir.

\section{PIT Taqqing}

During summer 1988, chinook and steelhead parr were tagged with an overall acute mortality of $0.4 \%$ (Table 8 ). Adjustments made in tagging procedures helped reduce the tagging mortality experienced in 1987 (3.1\%). High mortalities were encountered only on one occasion in 1988 when steelhead were anesthetized and tagged immediately after carrying them in buckets about $400 \mathrm{~m}$ from the collection site in hot weather. Seven out of 84 steelhead died. We believe that had we allowed the fish to acclimate in a live box before tagging, these mortalities could have been avoided.

We PIT-tagged parr in the USR during August 15-24. During the first four days, we tagged cooperatively with a NMFS tagging crew supervised by Steve Achord, targeting on chinook parr. For the last five days the IDFG crew targeted on steelhead parr. 
Table 7. Egg-to-Parr survival rates for natural chinook in USR.

\begin{tabular}{lccccc}
\hline & \multicolumn{5}{c}{ Brood rear } \\
\cline { 2 - 6 } & 1984 & 1985 & 1986 & 1987 & 1988 \\
\hline $\begin{array}{l}\text { Estimated number } \\
\text { of egg } \\
\text { deposition }\end{array}$ & $\mathbf{3 9 1 , 1 0 5 ^ { \mathrm { b } }}$ & 815,400 & $\mathbf{1 , 2 7 8 , 6 8 8}$ & $\mathbf{1 , 3 6 0 , 5 4 8}$ & $\mathbf{1 , 7 2 4 , 1 6 5}$ \\
$\begin{array}{l}\text { Parr } \\
\text { production }\end{array}$ & 73,548 & - & 65,739 & 70,319 & - \\
$\begin{array}{l}\text { Egg-to-Parr } \\
\text { survival }\end{array}$ & $18.8 \%$ & & $5.1 \%$ & $5.2 \%$ & \\
\hline
\end{tabular}

Table 2 .

b1984 escapement was probably underestimated by use of temporary weir.

Table 8. Collection and PIT tagging mortalities for USR, August 1988.

\begin{tabular}{lccc}
\hline & Chinook & Steelhead & Total \\
\hline Number tagged & 3,872 & 597 & 4,468 \\
$\begin{array}{l}\text { Collecting mortality } \\
\text { Number } \\
\text { Percent }\end{array}$ & 3 & 0 & 3 \\
$\begin{array}{l}\text { Tagging mortality } \\
\text { Number }\end{array}$ & $\mathbf{0 . 1 \%}$ & $0 \%$ & $0.1 \%$ \\
$\begin{array}{l}\text { Percent } \\
\text { Total mortality } \\
\text { Number } \\
\text { Percent }\end{array}$ & $\mathbf{7}$ & $7 \%$ & $\mathbf{1 4}$ \\
& $\mathbf{0 . 2 \%}$ & $1.2 \%$ & $\mathbf{0} \%$ \\
\end{tabular}


Five different 24-h delayed-mortality tests were conducted during the USR field tagging and resulted in a delayed mortality of $0.9 \%$ for chinook and $2.6 \%$ for steelhead (Table 9). A delayed-mortality test on Frenchman Creek chinook was conducted because the fish were extremely small (mean length $59 \mathrm{~mm}$ ). In addition to the two chinook that died in the Frenchman Creek test, one chinook (0.3\%) lost its tag. This was the only incidence of tag loss in any of the 198788 tests and probably resulted from small fish size.

Tests by NMFS (Prentice et al. 1986) and IDFG at Sawtooth Hatchery (unpublished data) showed that mortalities beyond 24 hours are negligible.

Length and weight data were collected on chinook and steelhead parr PITtagged during August 1987 and 1988. We summarized length data by location and by production type for chinook: natural spawning, adult outplants, and fry outplants (Table 10). The average length of naturally produced chinook parr in the USR were not significantly different between August 1987 (74 mm) (Kiefer and Apperson 1988) and August 1988 (76 mm). For naturally produced chinook parr length was similar in most locations in 1987 and 1988. However, chinook parr from ALC were the smallest naturally produced parr in 1987 (72 mm) and the largest in $1988(83 \mathrm{~mm})$. The density of chinook in the ALC study section ALC-

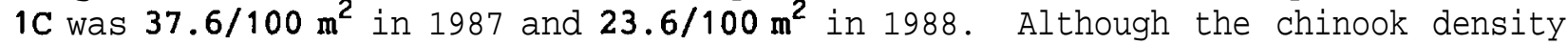
was greater in 1987, it was well below the estimated carrying capacity of 108/100 $\mathrm{m}^{2}$ (Petrosky and Holubetz 19881, and we do not believe that it was high enough to suppress the growth of chinook parr to the extent indicated by the length data. Since 1987 and 1988 were similar low water years, flow did not seem to be the factor controlling growth. Stream temperature, which may have controlled growth rates, was not monitored.

The small size of the chinook parr from the adult outplant in Frenchman Creek was probably a result of a combination of several factors. First, the adults outplanted were from the last of the run (September 1-4) so the eggs were deposited later than most naturally produced fish. Second, the temperature measurements we made during July-August indicate that Frenchman Creek is usually colder than the Salmon River (unpublished data), so the parr would have had fewer thermal units for growth. Third, the adults outplanted were confined and spawned in an area with high percent fines. Chapman (1988) reported that as the percent fines in a redd increase, the dissolved oxygen in the egg pocket decreases and the emerging fry are smaller.

We assumed that chinook parr tagged in Pole Creek and Smiley Creek were from the fry outplants since no chinook redds were observed in these areas in 1987. The outplanted chinook parr were longer (91 mm) than any other group because of the advanced growth they received in Sawtooth Hatchery. Of the three sites where outplanted chinook parr were tagged, those from PC-2B had a smaller mean size $(85 \mathrm{~mm})$ than those from PC-IB $(99 \mathrm{~mm})$ or $\mathrm{SC}-1$ (98 $\mathrm{mm})$. This slower chinook fry-to-parr growth at $\mathrm{PC}-2 \mathrm{~B}$ was probably caused by thermal stress resulting from elevated water temperature due to irrigation withdrawal. In low 
Table 9. Twenty-four hour delayed mortality test results for USR.

\begin{tabular}{|c|c|c|c|c|}
\hline Taq site & $\begin{array}{l}\text { Collection } \\
\text { method }\end{array}$ & \# held & $\#$ morts. & $\frac{0}{0}$ morts. \\
\hline \multicolumn{5}{|c|}{$\underline{\text { Chinook }}$} \\
\hline $\begin{array}{l}\mathrm{FC}-2 \mathrm{~A} \\
\mathrm{PC}-1 \mathrm{~B} \\
\mathrm{SR}-7 \mathrm{~A}\end{array}$ & $\begin{array}{l}\text { Seine } \\
\text { Shock } \\
\text { Seine }\end{array}$ & $\begin{array}{r}305 \\
34 \\
125\end{array}$ & $\begin{array}{l}2 \\
0 \\
? \\
1\end{array}$ & $\begin{array}{l}0.7 \% \\
0.0 \% \\
1.6 \%\end{array}$ \\
\hline${ }_{S R} E_{g}{ }^{1 C}$ & shock & 78 & 0 & $\begin{array}{l}1.3 \% \\
0.0 \%\end{array}$ \\
\hline Total & Seine & 430 & 4 & $0.9 \%$ \\
\hline Total & Shock & 126 & 1 & $0.8 \%$ \\
\hline $\begin{array}{l}\text { Overall } \\
\text { totals }\end{array}$ & & 556 & 5 & $0.9 \%$ \\
\hline \multicolumn{5}{|c|}{$\underline{\text { Steelhead }}$} \\
\hline $\begin{array}{l}\text { PC-1B } \\
\text { SR-7A } \\
\text { ALC-1C } \\
\text { SR-9 }\end{array}$ & $\begin{array}{l}\text { Shock } \\
\text { Seine } \\
\text { Shock } \\
\text { Shock }\end{array}$ & $\begin{array}{l}56 \\
21 \\
17 \\
62\end{array}$ & $\begin{array}{l}1 \\
0 \\
1 \\
2\end{array}$ & $\begin{array}{l}1.8 \% \\
0.0 \% \\
5.9 \% \\
3.2 \%\end{array}$ \\
\hline Total & Shock & 135 & 4 & $3.0 \%$ \\
\hline Total & Seine & 21 & 0 & $0.0 \%$ \\
\hline $\begin{array}{r}\text { Overall } \\
\text { totals }\end{array}$ & & 156 & 4 & $2.6 \%$ \\
\hline
\end{tabular}


Table 10. Average lenghts of PIT-tagged parr from USR.

\begin{tabular}{|c|c|c|c|c|c|}
\hline Taq Site & $\begin{array}{c}\text { Chinook } \\
\text { rearing type }\end{array}$ & $\begin{array}{c}\text { \# chinook } \\
\text { taqqged }\end{array}$ & $\begin{array}{l}\text { Chinook-avg. } \\
\text { length (mm) }\end{array}$ & $\begin{array}{c}\text { \# } \begin{array}{c}\text { Steelhead } \\
\text { tiqqred }\end{array} \\
\text { tise }\end{array}$ & $\begin{array}{l}\text { Steelhead-avg. } \\
\text { length (mm) }\end{array}$ \\
\hline $\begin{array}{l}F C-2 A \\
F C-1 \\
A L C-1 C \\
\text { SR-3A } \\
\text { SR-3B } \\
\text { SR-35A } \\
\text { SR-4BRB } \\
\text { SR-7A } \\
\text { SR-10A } \\
\text { PC-1B } \\
\text { PC-2B } \\
\text { SC-1 } \\
\text { SR-8A } \\
\text { SR-9 }\end{array}$ & $\begin{array}{l}\text { Adult outplant } \\
\text { Natural } \\
\text { Natural } \\
\text { Natural } \\
\text { Natural } \\
\text { Natural } \\
\text { Natural } \\
\text { Natural } \\
\text { Natural } \\
\text { Fry outplant } \\
\text { Fry outplant } \\
\text { Fry outplant } \\
\text { Mixed } \\
\text { Mixed }\end{array}$ & $\begin{array}{r}302 \\
8 \\
414 \\
\mathbf{4 5} \\
\mathbf{9 9 2} \\
610 \\
761 \\
309 \\
0 \\
46 \\
215 \\
107 \\
\mathbf{2 2} \\
\mathbf{3 3}\end{array}$ & $\begin{array}{l}59 \\
79 \\
83 \\
72 \\
76 \\
71 \\
76 \\
80 \\
-99 \\
99 \\
85 \\
98 \\
80 \\
88\end{array}$ & $\begin{array}{r}0 \\
45 \\
32 \\
0 \\
23 \\
5 \\
4 \\
3 \\
78 \\
62 \\
24 \\
45 \\
163 \\
112\end{array}$ & $\begin{array}{c}143 \\
135 \\
- \\
\mathbf{8 0} \\
94 \\
117 \\
143 \\
147 \\
146 \\
122 \\
140 \\
140 \\
142\end{array}$ \\
\hline Total & Adult outplant & 302 & 59 & - & - \\
\hline Total & Natural & 3,139 & 76 & - & - \\
\hline Total & Fry outplant & 368 & 91 & - & - \\
\hline Total & Mixed & 55 & 85 & - & - \\
\hline $\begin{array}{c}\text { Overall } \\
\text { total }\end{array}$ & & 3,872 & 76 & 597 & 138 \\
\hline
\end{tabular}


water years, such as 1988, most of Pole Creek is diverted for hay field irrigation. Much of the water powers a sprinkler system and then returns to the creek $4.4 \mathrm{~km}$ below the diversion. On August 22, 1988, water temperature immediately above and below the return point was $25.5^{\circ} \mathrm{C}$ and $12.0^{\circ} \mathrm{C}$, respectively.

The mean length of the steelhead parr tagged in August 1988 was $138 \mathrm{~mm}$, somewhat larger than parr tagged in August 1987 (130 mm). This difference in length was surprising, since in 1987 we primarily tagged only age-1 + and -2+ steelhead parr, whereas in 1988 we tagged any steelhead parr larger than $60 \mathrm{~mm}$. We believe this is a result of the low population of age-l steelhead as observed during our snorkel counts.

\section{Spring 1988 Outmiqration Trapping}

In spring 1988, the Sawtooth Weir trap (SWT) operating alone had a trapping efficiency of $6.7 \%$ for chinook and $2.9 \%$ for age-1+ and $\mathbf{- 2 +}$ steelhead. When both SWT and the Sawtooth intake trap (SIT) were operated, the combined trapping efficiency was 8.2\% for chinook and 3.3\% for age-1+ and -2+ steelhead. Overall, during spring 1988 we captured 1,679 chinook smolts, with a trapping efficiency of $\mathbf{7 . 4 \%}$, and a total estimated run of 22,643. For steelhead age-1+ and $\mathbf{- 2 +}$ the overall numbers were 275 captured, trapping efficiency of $\mathbf{3 . 0 \%}$, and a run estimate of 9,200. Based on the summer 1987 parr population estimates (Table 7), we estimate that $34.4 \%$ of chinook parr and $45.7 \%$ of the age-1 + and $\mathbf{- 2 +}$ steelhead parr outmigrated in spring 1988.

We used the combined SWT and SIT trap efficiency and daily catch data to determine the timing of the spring 1988 outmigration from USR (Figure 3). Peak spring outmigration for both species occurred between April 4 and April 16, when $46 \%$ of the chinook and $54 \%$ of the steelhead outmigrated. Although both species had the same period of maximum migration and a moderate peak in the graph between May 7 and May 15, chinook had a relatively higher percent of outmigrants before April 4, and in general left slightly before the steelhead.

The spring 1988 outmigration timing was compared to water depth at the sill at Sawtooth Hatchery weir as a preliminary attempt to determine stimuli that initiates migration (Figure 4). In spring 1988, migration of steelhead and chinook appeared to be initiated by the approach of storms. Factors that stimulate outmigration (photoperiod, barometric pressure, temperature, and flows) will be investigated in future analyses to improve predictions of arrival of wild/natural smolts to Lower Granite (LGR) Pool.

\section{Fall 1988 Outmisration Trapping}

In fall 1988, the SWT was operated from August 16-october 31. The SWT had an overall trapping efficiency of $8.4 \%$ for chinook and $9.7 \%$ for steelhead. The SWT captured a total of 4,732 chinook for a run estimate of 56,134, and 347 


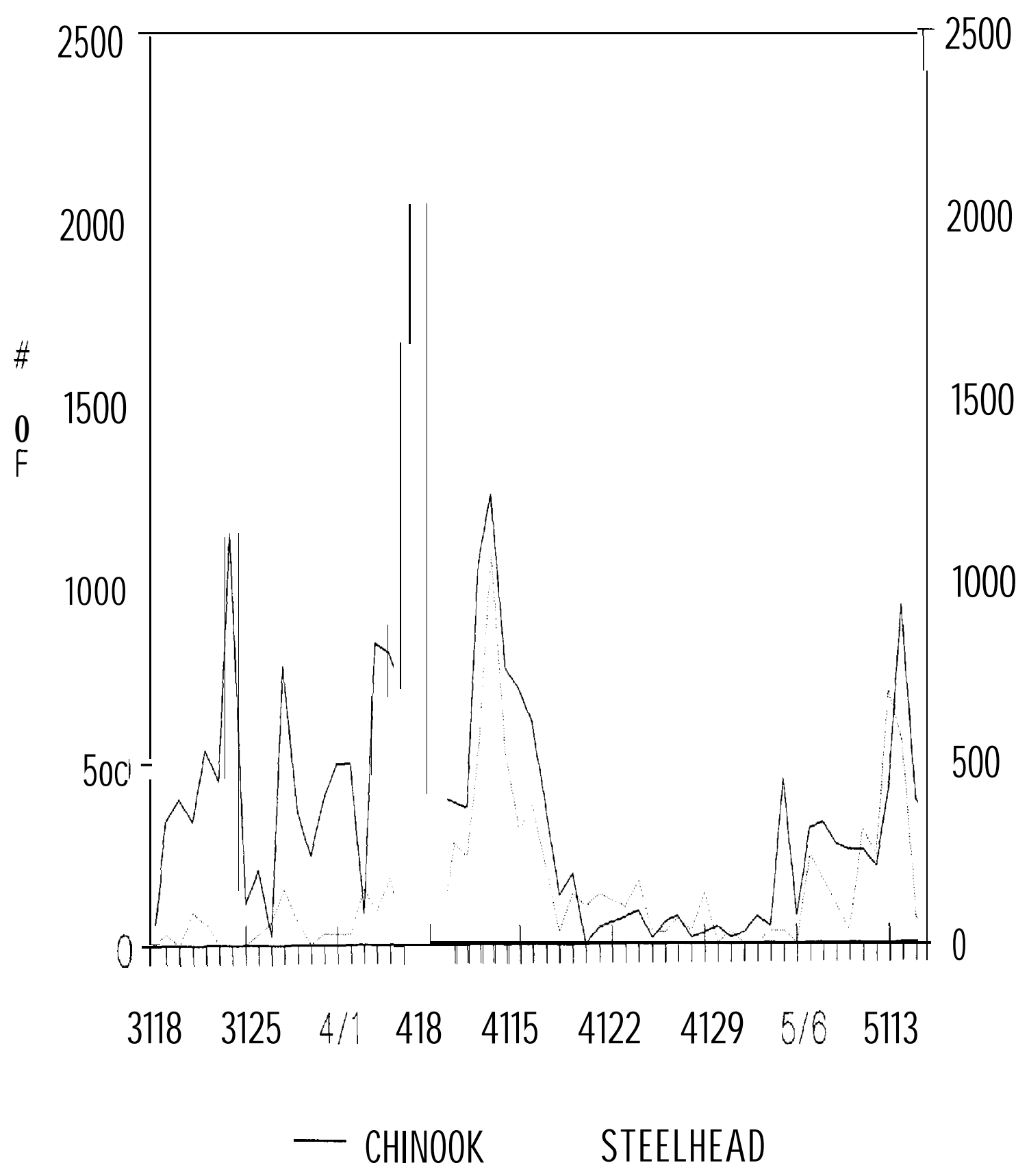

Figure 3. Spring 1988 USR run estimates. 


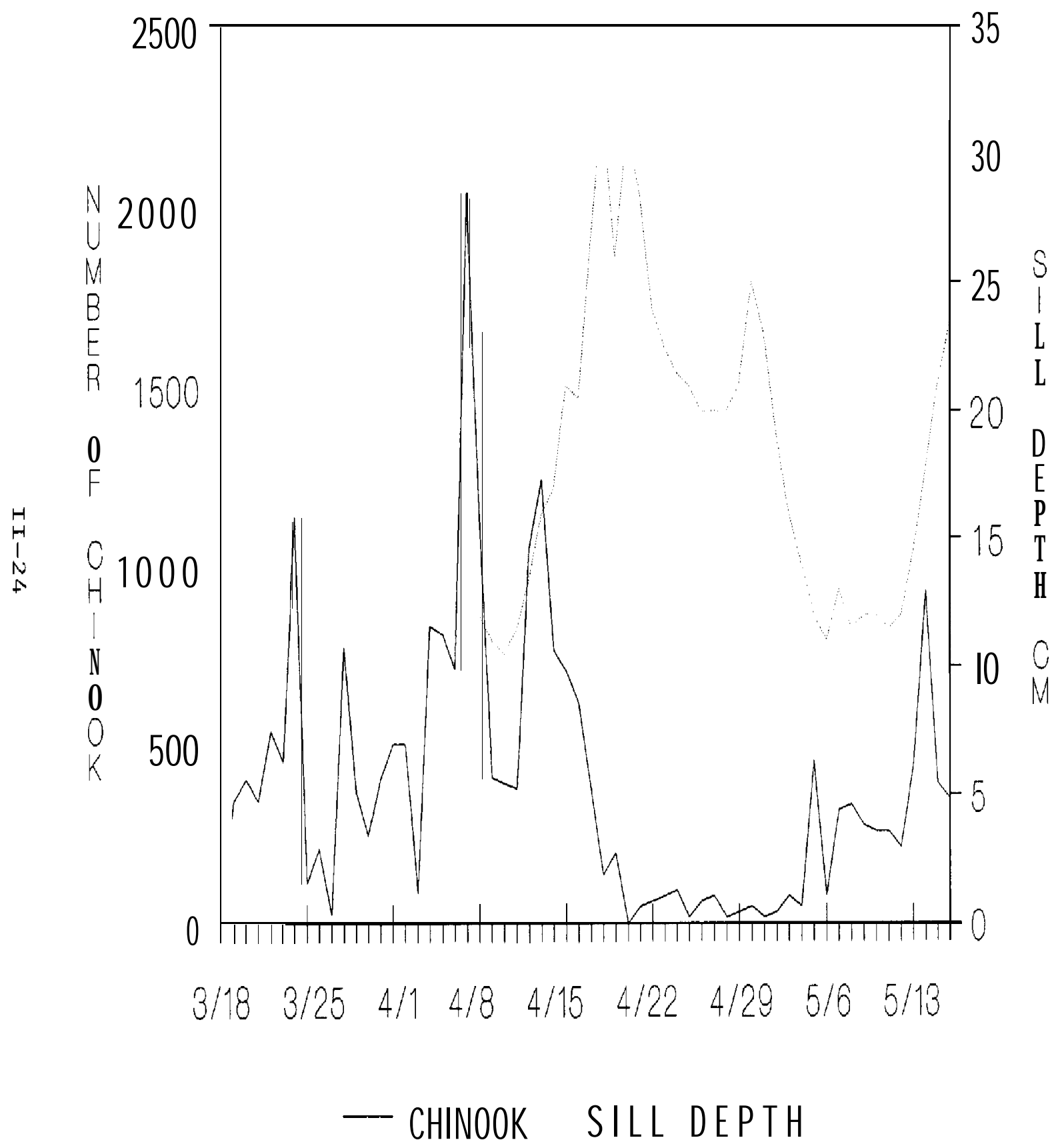

Figure 4. Spring 1988 USR chinook run estimate and sill depth. 
steelhead for a run estimate of 3,570. Based on the summer 1988 parr population estimates, $64 \%$ of the chinook and 48\% of the steelhead outmigrated in fall 1988.

During the fall 1988 trapping season, we conducted tests to determine if there was a difference in the recapture efficiency of fish released immediately after tagging (day release) or those held until dusk in perforated live boxes (night release). The night released parr of both species were recaptured at a higher rate; chinook day release $7.2 \%$ and night release 12.4\%, and steelhead day release $9.6 \%$ and night release $12.2 \%$. The reason behind this difference in trap efficiency depending on time of release is not known. The combined trap efficiency estimates will be used in the calculations until we are able to determine which is the better estimator.

As in spring 1988, the fall 1988 SWT data show that both chinook and steelhead had migration peaks on the same days (Figure 5), indicating that both species keyed to the same stimuli. Whereas the spring 1988 data suggest that the fish moved just before storm events, the fall 1988 data suggest that they moved during storm events (Figures 6 and 7). Storm events show up as sharp drops in temperature and rises in sill depth on the same days. During fall 1988, both species migrated at similar times, with most of the migration occurring between mid-August and mid-October.

In addition to sampling fish reared in natural habitat, we outplanted two groups of 21,000 chinook parr, of which 300 from each group were PIT-tagged. One group was released on october 11 into lower ALC, and the other group was released on October 12 into the headwaters of the Salmon River. We recaptured a total of 26 PIT-tagged parr from these release groups, with the SWT during fall 1988. All PIT tag recaptures were from the ALC release. The 26 recaptures at SWT represent $8.7 \%$ of the total tagged for that group. Since the recapture rate for the release group into ALC and the overall SWT recapture rate for chinook ( $8.4 \%)$ were not significantly different, we believe that virtually all the release group into ALC outmigrated during the fall. Untagged parr from these releases could be visually differentiated from natural parr by size and body color. SWT captured a total of 1,537 parr from these outplants, for a run estimate of 18,298 or $87 \%$ of the ALC outplant. These hatchery parr were not included in the natural run estimates for USR. Apparently the chinook parr released into the Salmon River headwaters were unable to migrate past the dewatered section below S45 diversion. When the 1989 dam detections are analyzed, we will investigate the impact of the dewatering on the survival of the USR release group. 


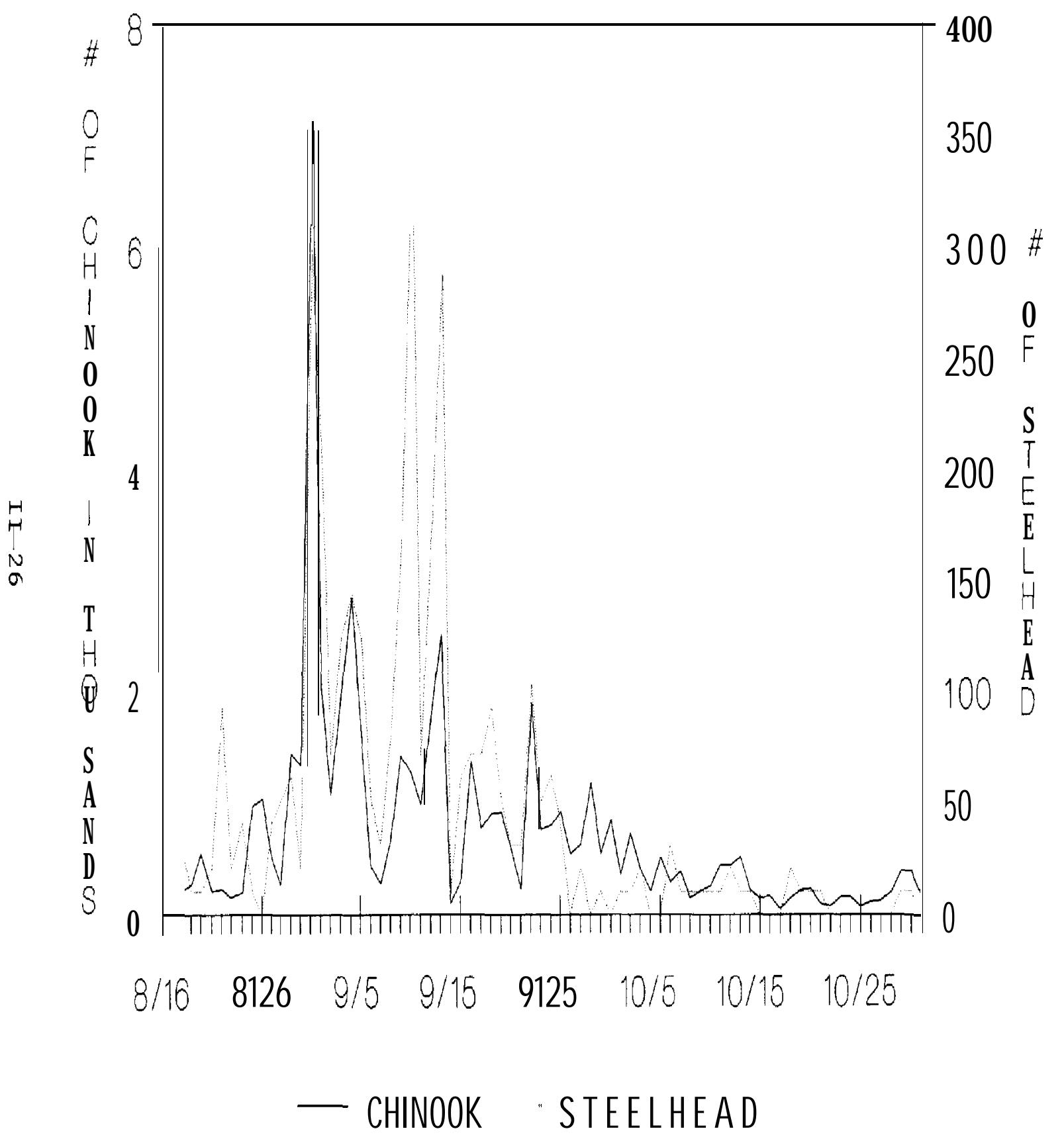

Figure . Fa 1988 USR run estimates. 


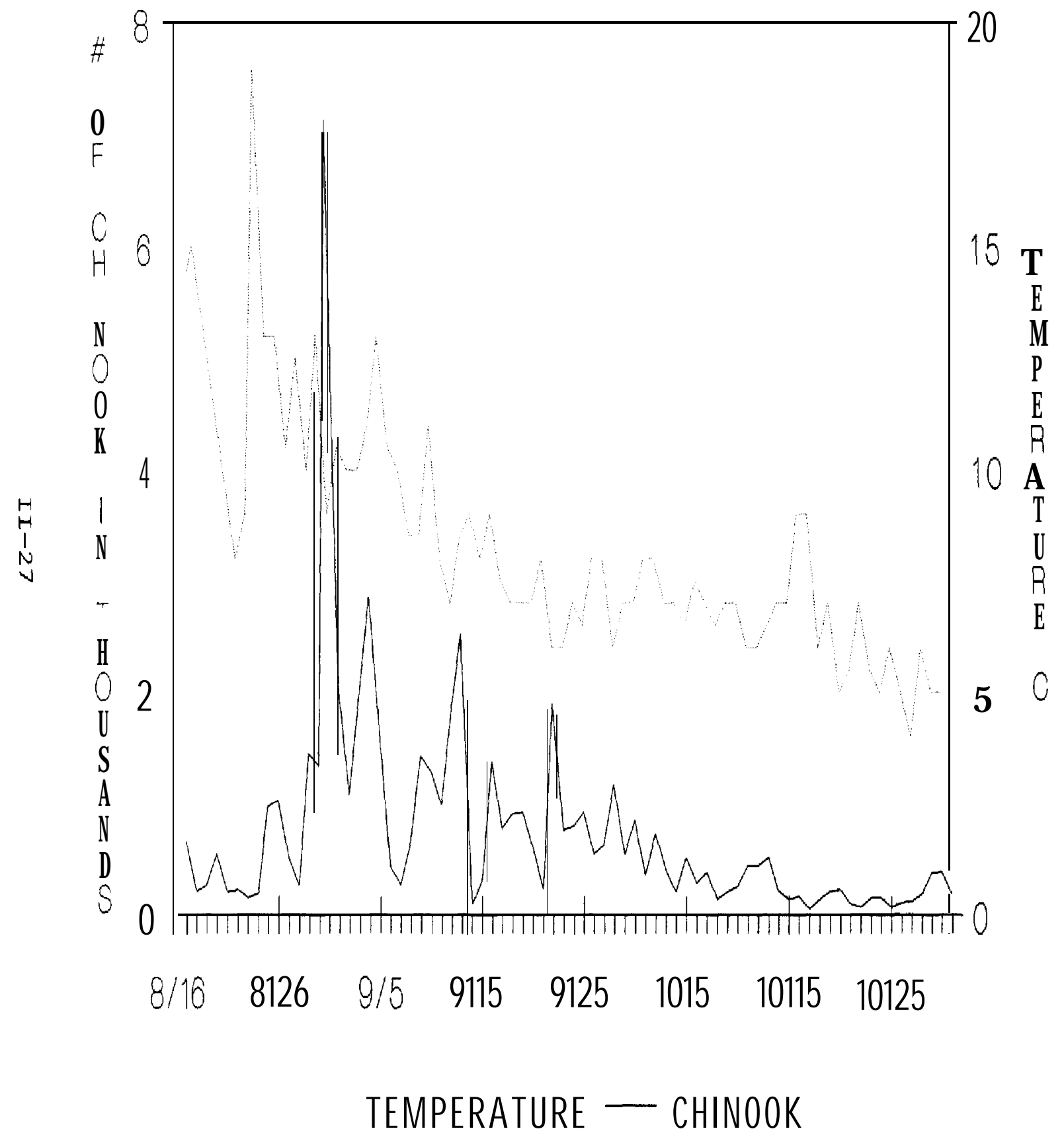

Figure 6. Fall 1988 USR chinook run estimate and daily (10:00 am) stream temperature. 


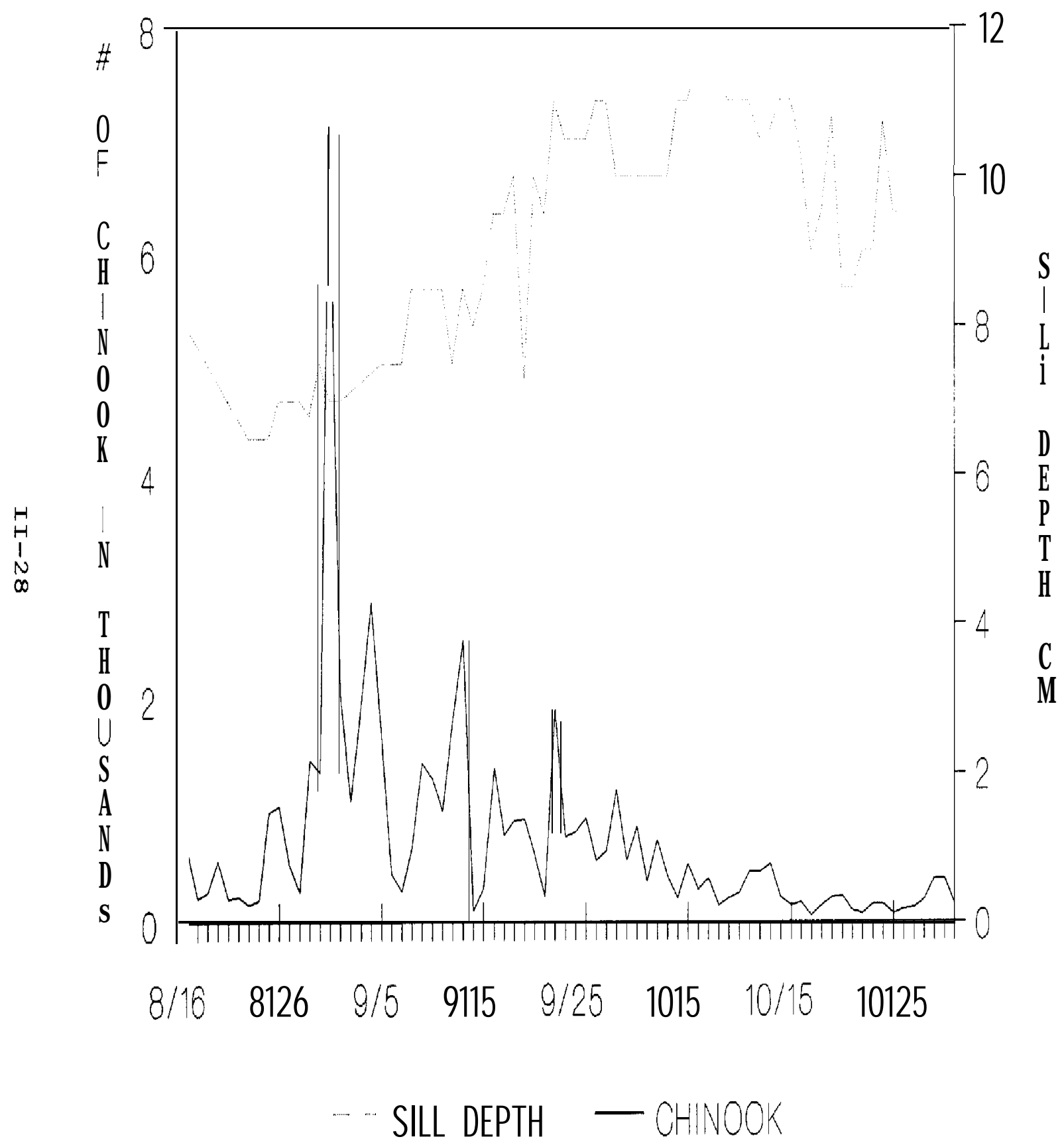

Figure 7. Fall 1988 chinook run estimate and sill depth. 
During the spring 1988 outmigration we captured and PIT-tagged chinook and steelhead smolts at SWT that were later detected at Lower Granite (LGR) Dam. We then calculated mean travel time. We observed three different patterns for chinook travel time (Figure 8). First, from the first date of trapping, March 18, until the beginning of peak migration, April 4, the travel time decreased progressively from about 65 days to 45 days. Second, during the period of peak migration, April 5-19, the travel time averaged 43 days. Third, after the peak migration, April 20-May 16, the travel time decreased to about 25 days. With fewer data points for steelhead we could only determine that the pattern was similar to that for chinook, and on almost all release dates steelhead traveled faster to LGR dam.

PIT-tagged chinook from the USR arrived later than the peak of the total chinook run at LGR Dam (Figure 9). There are two possible reasons for the later arrival for USR chinook. First, it takes the USR smolts longer to get to LGR Dam because they have farther to migrate than any other smolts passing the dam. Second, natural/wild chinook smolts may have a later migration timing than hatchery smolts, and the larger number of hatchery smolts moves up the peak of the total migration.

Because all hatchery steelhead smolts had adipose fin clips, the arrival of USR natural steelhead can be compared with total wild/natural steelhead at LGR Dam. The USR natural steelhead arrived during the same time as the total wild/natural smolt run and with basically the same peaks (Figure 10). The natural chinook from USR also arrive at LGR Dam during this same period (Figure 11). Water Budget decisions based solely on peaks of the run could therefore affect specific populations in different ways.

Nelson and Buettner (1989) observed average travel times through LGR Reservoir of 15 days for chinook and 4 days for steelhead in 1988. We used these travel times to estimate that the peak of the USR smolt runs in 1988 arrived at LGR Pool between April 27 and May 20 for chinook and between May 12 and June 4 for steelhead. The peaks of arrival at LGR Dam of USR PIT-tagged chinook and steelhead smolts corresponded with periods of increased flows at LGR dam (Figure 12). Thus, it is possible that the USR smolts reached the head of LGR Pool before the estimated dates and were delayed until flows increased.

We estimated survival of USR chinook from the parr stage to smolt stage at the head of LGR Pool. In spring 1988, 4.1\% of all USR chinook parr PIT-tagged in 1987 were detected at LGR Dam. Nelson and Buettner (1989) found that the mean detection at LGR Dam was 33.4\% for chinook smolts that they PIT-tagged at the Snake River trap at the head of LGR Pool in 1988. These data imply that $12.3 \%$ of the chinook parr from USR in summer 1987 survived to smolts at the head of LGR Pool. Thus, the estimated 65,739 chinook parr in USR during summer 1987 produced an estimated 8,070 chinook smolts to the head of LGR Pool.

For steelhead, LGR Dam facilities detected $4.0 \%$ of the age-1+ and $-2+$ parr tagged in the USR in summer 1987. Nelson and Buettner (1989) found a mean 


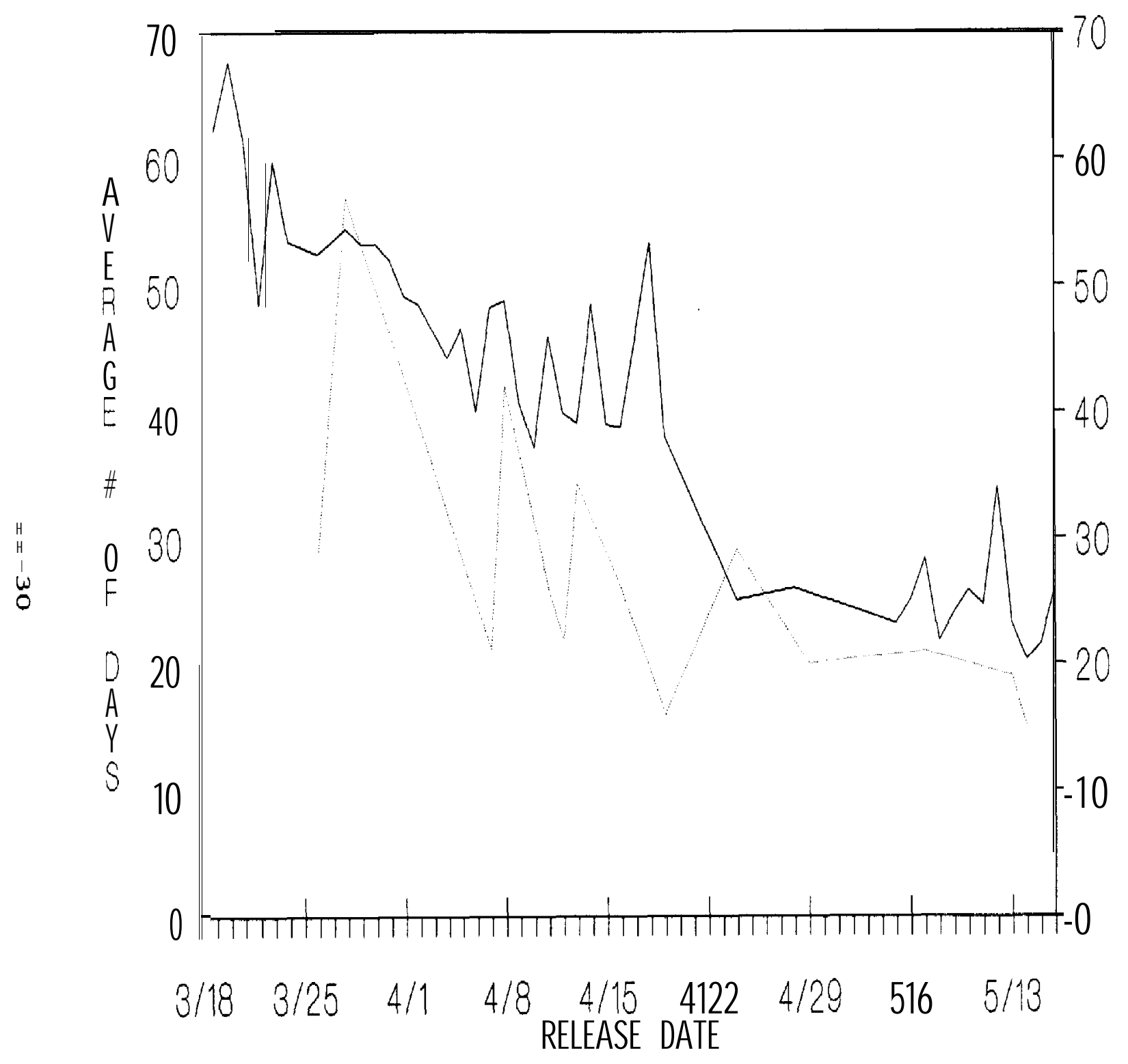

- STEALH EAD - CHINOOK

Figure 8. Spring 1988 travel time for smolts tagged at SWT and detected at LGR dam. 


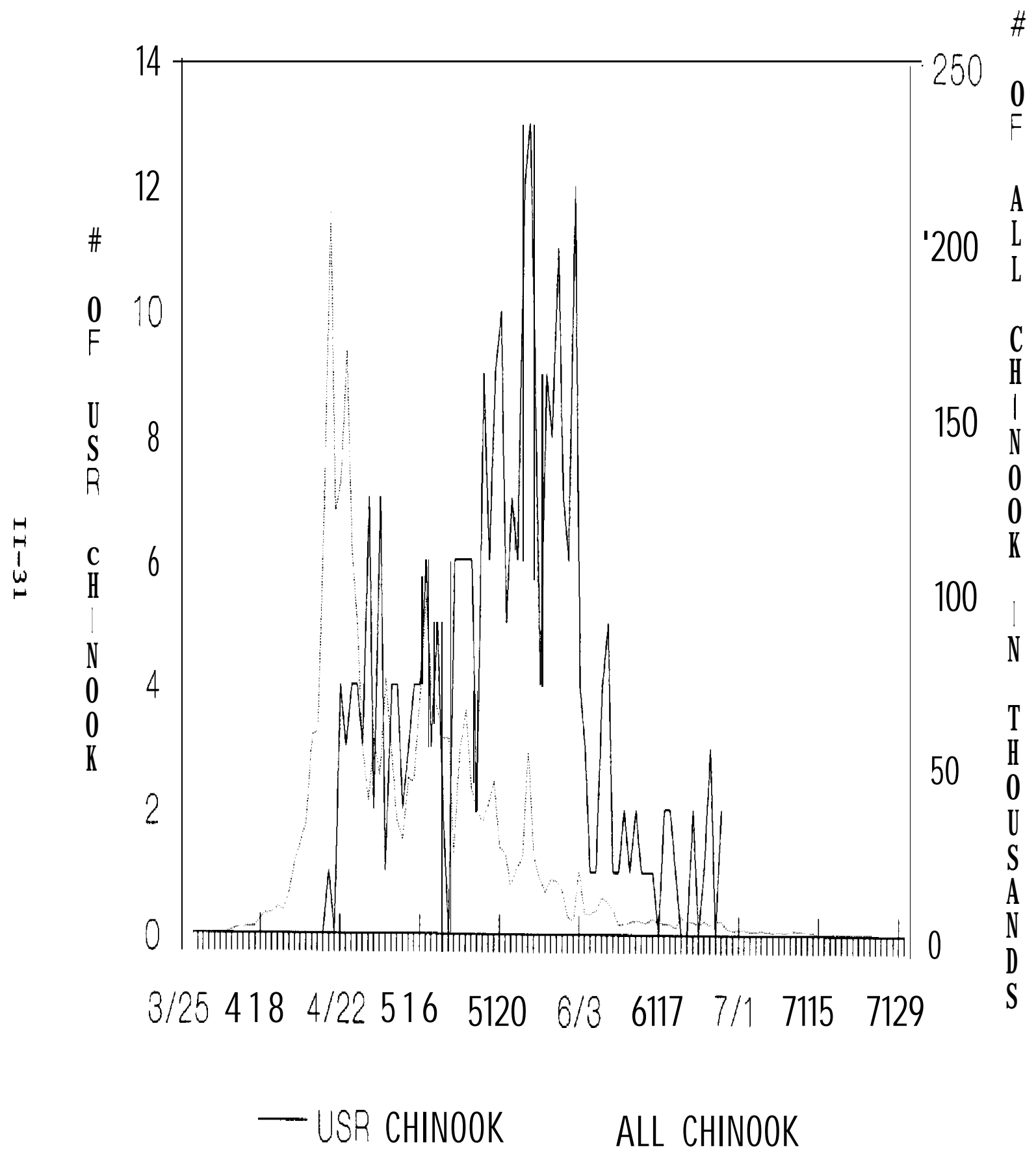

Figure 9. Spring 1988 daily number of USR chinook detections at LGR dam and daily chinook run estimates at LGR dam. 


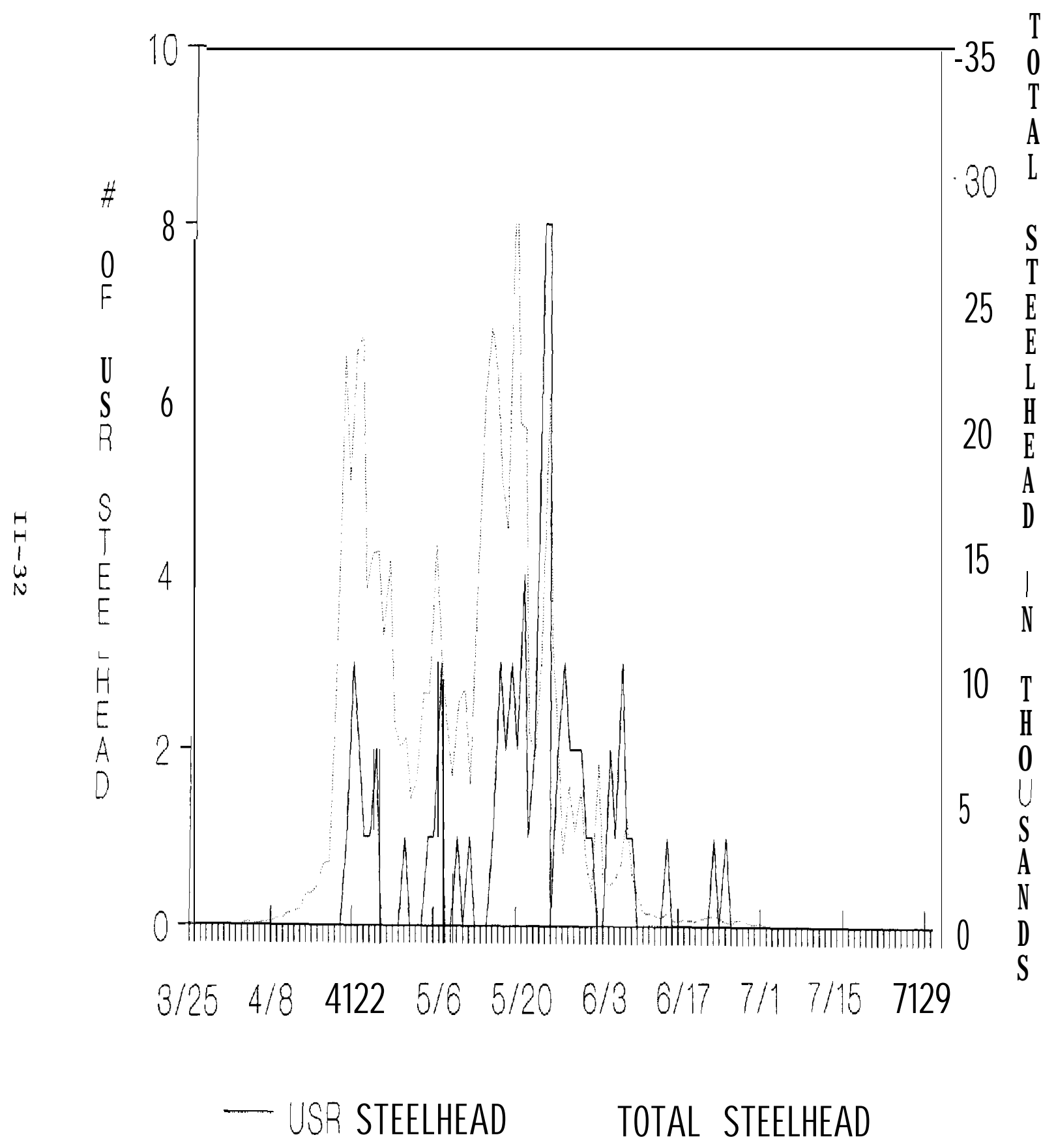

Figure 10. Spring 1988 daily number of USR steelhead detections at LGR dam and daily total ild/natural steelhead run estimates at LGR dam. 


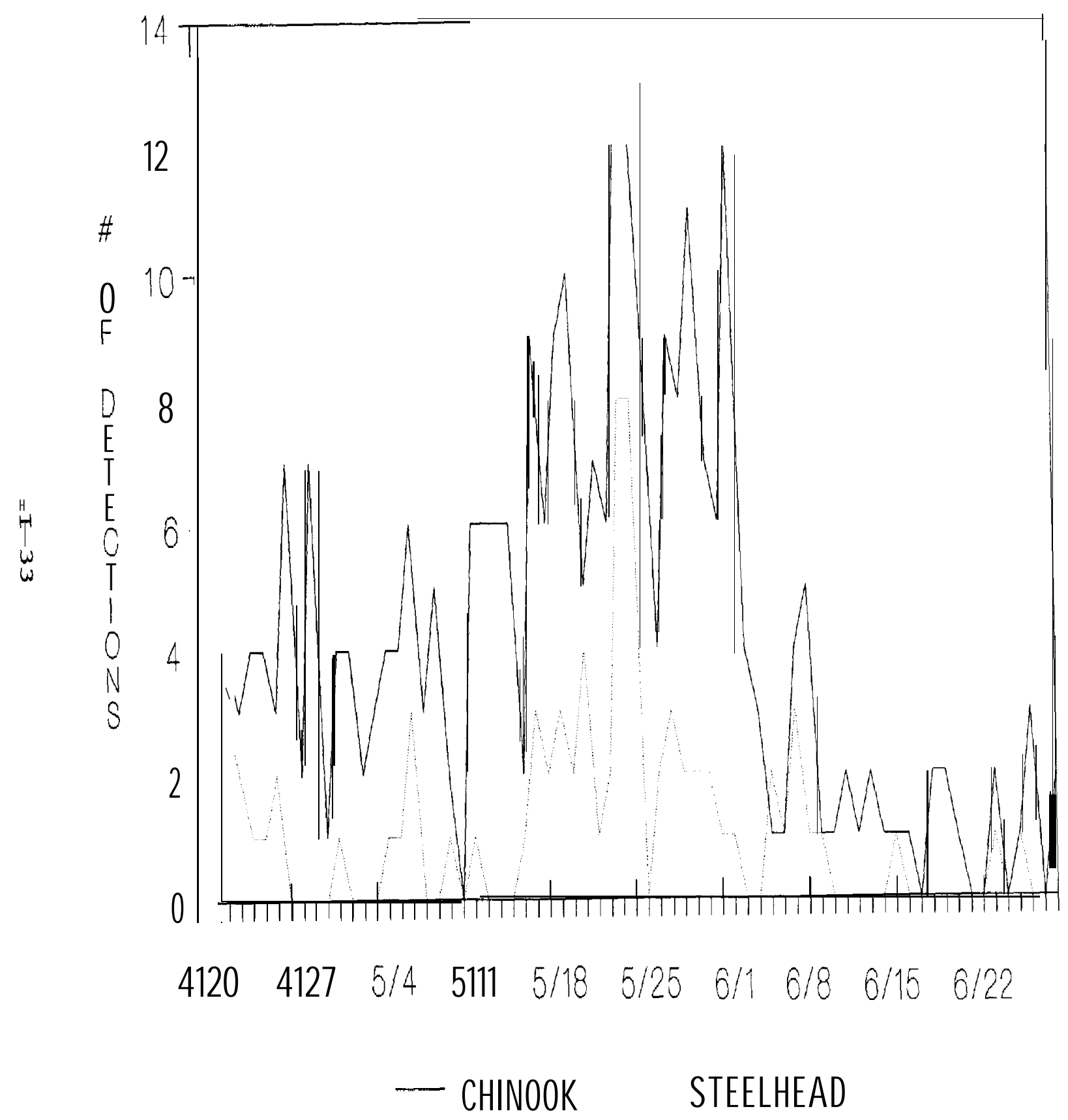

Figure 1. 1988 uSR chinook and steelhead detections at LGR dam. 


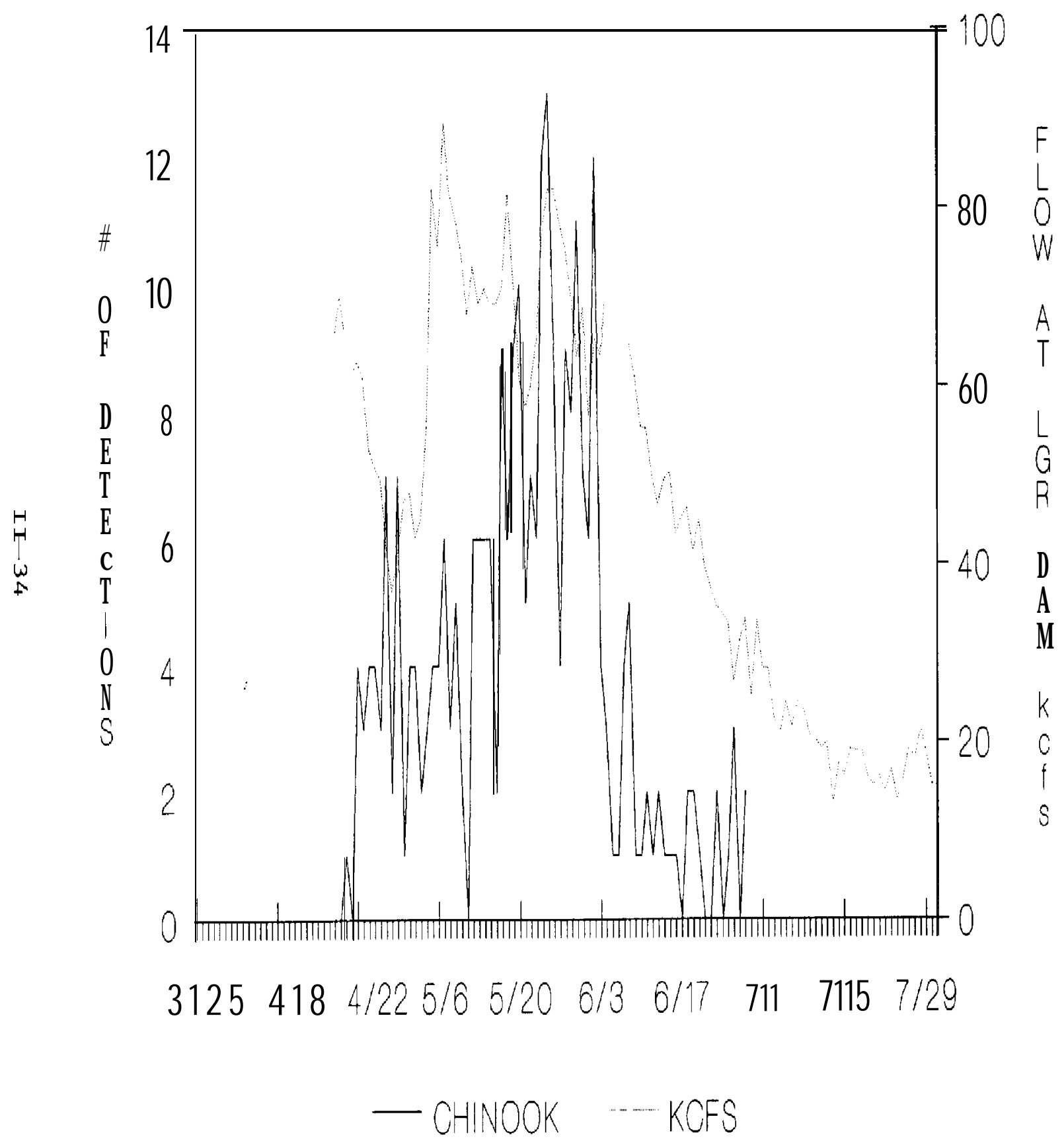

Figure 12. Spring 1988 daily number of USR chinook detections at LGR dam and flows (kcfs) at LGR dam. 
detection rate of $59.9 \%$ at LGR Dam for the steelhead smolts that were PIT-tagged at the Snake River trap in 1988. These data imply that out of the 20,132 age$1+$ and $-2+$ steelhead in the USR during summer 1987, 6.8\% (1,361) smolted and survived the head of LGR Pool. The estimated steelhead parr-to-smolt survival rate was low because many of the steelhead that we PIT-tagged in summer 1987 were below smolting size. The estimate of the number of steelhead smolts produced should be fairly accurate because the percent survival and the summer 1987 parr population used in the calculations are both from age-1+ and $\mathbf{- 2 +}$ steelhead. The dam detections show that very few age-l steelhead ( $130 \mathrm{~mm}$ ) from USR successfully smolted in 1988 (Table 11). If we assume that the estimated 1,361 steelhead smolts were only from the 5,852 age-2+ steelhead parr, then we can calculate a USR age-2+ steelhead parr to LGR Pool smolt survival rate of 23.3\%. Better definition of age and size at smolting will be necessary for steelhead in future studies.

Size of fish influenced survival to LGR Dam. Smaller chinook smolts $(<70$ $\mathrm{mm}$ ) that were PIT-tagged in spring 1988 survived at nearly two-thirds the rate of large smolts $(>90 \mathrm{~mm})$, better than we had anticipated. Steelhead smaller than $130 \mathrm{~mm}$ were not detected in any significant numbers at LGR Dam. Thurow (1985) found $130 \mathrm{~mm}$ to be the separation point between age-l and age-2+ steelhead for similar Idaho streams. This suggests that only age-2+ steelhead from USR smolt. The smaller steelhead probably rear another year before smolting.

The PIT tag detections at LGR Dam indicate that the S45 diversion was a major source of mortality for both chinook and steelhead parr rearing above it (Table 12). The impact of the 545 diversion was probably greater on steelhead because approximately $2 / 3$ of the total steelhead population occurred above the diversion.

The method used to capture chinook parr for PIT tagging appeared to affect their survival. Chinook collected below the 545 diversion by electrofisher were detected at a rate of $4.7 \%$ at LGR Dam, while chinook collected with a seine from the same area were detected at a rate of $7.5 \%$. Chinook collected by electrofisher may have experienced a delayed mortality beyond the 24-h tests. We did not collect enough steelhead by seine in any area to compare the method of collection with survival rate.

\section{CROOKED RIVER}

\section{RESULTS AND DISCUSSION}

\section{Adult Escapement and Redd Counts}

Total and female escapement numbers will not be available for CR until the weir and trap are completed in 1990. Known escapements will be correlated with redd counts for chinook and possibly steelhead. Total egg deposition will be estimated using known female escapement and fecundity from CR when available. 
Table 11. Fish length and smolt success for USR, 1988.

\begin{tabular}{lc}
\hline Length $(\mathrm{mm})$ & $\frac{0}{0}$ \\
\hline Chinook $<70$ & 18.8 \\
Chinook $70-79$ & 22.6 \\
Chinook $80-89$ & 25.3 \\
Chinook > 89 & 29.5 \\
Steelhead <130 & 0.6 \\
Steelhead $130-139$ & 10.0 \\
Steelhead $140-149$ & 12.5 \\
Steelhead $150-159$ & 25.0 \\
Steelhead $>159$ & 37.0 \\
\hline
\end{tabular}

Table 12. Percent detection of 1987 PIT tagged USR parr by smolt collecting dams, 1988.

\begin{tabular}{llccc}
\hline Species & Location & $\begin{array}{c}\text { Number } \\
\text { tagged }\end{array}$ & \% detection \\
\hline \multirow{2}{*}{ Chinook } & Above S45 Diversion & 832 & 1.3 \\
& Below S45 Diversion & 1,929 & 5.3 \\
\multirow{5}{*}{ Steelhead } & Above S45 diversion & 985 & 2.8 \\
& Below S45 diversion & 432 & 6.9 \\
& & & & \\
\hline
\end{tabular}


In 1988, a one-pass ground count of chinook redds over the total probable spawning area of CR was conducted on September 3 and September 8 . We counted 43 redds for the total probable spawning area and 29 redds for the traditional trend count reach (narrows to the forks). The helicopter redd count for the traditional trend count reach was 27 redds.

Preliminary estimates of female escapement and total egg deposition for 1984-88 (Table 13) were made based on the ratio of the 1988 total redd count to trend count (43 total; 27 trend) and past trend counts. In 1988, several chinook redds were observed in the gravel cleaned by heavy machinery crossing the stream during the construction of flow control structures by the USFS in stratum 4. Since these chinook apparently spawned in the machinery-cleaned gravel, a higher percentage of the total redds may have been built in the lower meadow reach of CR. If the distribution pattern of chinook redds was altered in 1988 by attraction to the artificially cleaned gravel, then total escapement and egg deposition would be over-estimated in 1984-88.

A one-pass ground count for steelhead redds was attempted for $\mathrm{CR}$ on May 23, 1988. However, because of the moderately turbid water, only three redds were observed between the narrows and the forks, and the count was not considered usable. In 1989, a helicopter steelhead redd count will be attempted on CR in early May to determine the usefulness of aerial steelhead redd counts. Steelhead escapement and egg deposition cannot be estimated for CR from existing data.

\section{Hatchery Sumlementation}

Hatchery supplementation data for brood years 1984-88 are summarized in Tables 14 and 15. Supplementation research by this subproject is scheduled to begin in 1990 .

\section{Parr Density}

Intensive monitoring of CR parr populations began in 1988. The general monitoring subproject has collected parr density data since 1984, with evaluations of the barrier removal, in-stream structures, and off-channel ponds in 1985 and 1986. Chinook densities for 1984-88 are summarized in Table 16. Chinook parr densities were lower in 1988 than in either 1985 or 1986 and higher than in 1987.

Chinook redd counts and hatchery supplementation partially explain parr densities observed in 1985-88. The two higher redd counts (22 in 1984 and 17 in 1987; Table 13) resulted in the relatively higher parr densities in 1985 and 1988 (Table 16). The low redd count (10) in 1985 combined with a large fry outplant resulted in relatively high parr densities in 1986. The low redd count in 1986 (9) with no fry supplementation resulted in the low parr density in 1987.

The connected ponds had the highest chinook parr densities in 1988, and one of the highest in 1986 (Table 16). We anticipate that the mitigation 
Table 13. Estimated chinook salmon adult escapement, redd counts, and number of eggs deposited for $\mathrm{CR}$.

\begin{tabular}{|c|c|c|c|c|c|}
\hline & \multicolumn{5}{|c|}{ Chinook Salmon } \\
\hline & \multicolumn{5}{|c|}{ Brood year } \\
\hline & 1984 & 1985 & 1986 & 1987 & 1988 \\
\hline Trend redd count & 22 & 10 & 9 & 17 & 27 \\
\hline Ground redd count & -- & -- & -- & -- & 43 \\
\hline $\begin{array}{l}\text { Estimated female } \\
\text { escapement }=\end{array}$ & 35 & 16 & 14 & 27 & 43 \\
\hline Eggs/female $e^{b}$ & 4,432 & -- & -- & 4,010 & -- \\
\hline $\begin{array}{l}\text { Estimated number } \\
\text { eggs deposited }\end{array}$ & 155,120 & 67,536 & 59,094 & 108,270 & 181,503 \\
\hline
\end{tabular}

${ }^{\text {a Female escapement estimate based on 1:1 ratio of female escapement }}$ to ground redd counts observed in USR, and 43:27 ratio of ground to trend redd counts observed in 1988.

'Average \# of eggs/female obtained from nearby Red River trapping facility in 1984 and 1987. We used 1984 and 1987 average from brood years for which data were not available. 
Table 14. CR chinook supplementation, summary by brood year 1984-88.

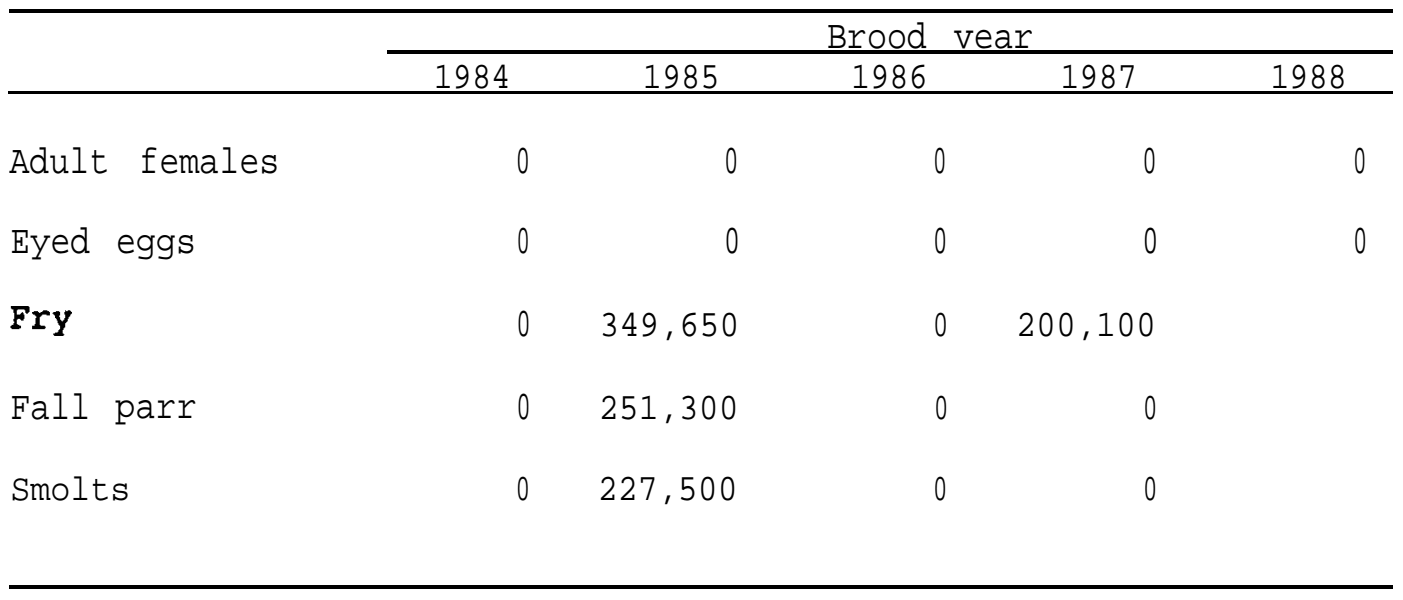

Table 15. CR steelhead supplementation, summary by brood year 1984-88.

\begin{tabular}{|c|c|c|c|c|c|}
\hline & & & Brood & & \\
\hline & 1984 & 1985 & 1986 & 1987 & 1988 \\
\hline Adult females & 0 & 1,522 & 0 & 468 & 0 \\
\hline Fry & 0 & 0 & 87,750 & 0 & \\
\hline Fall parr & 0 & 0 & 0 & 0 & \\
\hline Smolts & 42,235 & 140,825 & 158,538 & 201,325 & \\
\hline
\end{tabular}


Table 16. Density (number $/ 100 \mathrm{~m}^{2}$ ) of age-0 chinook in $\mathrm{CR}$, August 1984-1988.

\begin{tabular}{|c|c|c|c|c|c|}
\hline Stratum & 1984 & 1985 & 1986 & 1987 & 1988 \\
\hline Headwaters & & & & & 0.03 \\
\hline I & 0 & 20.80 & 13.97 & 3.01 & 23.77 \\
\hline II & & 71.30 & 21.67 & 1.08 & 16.47 \\
\hline Canyon & & & & & 8.05 \\
\hline III & 32.20 & & 57.80 & 22.33 & 36.64 \\
\hline IV & 3.80 & 66.30 & 71.75 & 15.37 & 42.21 \\
\hline Relief Creek & & & & & 0.82 \\
\hline $\begin{array}{c}\text { Connected } \\
\text { Ponds }\end{array}$ & & & 62.86 & 3.20 & 65.39 \\
\hline
\end{tabular}


activities to connect additional off-channel ponds will result in significant increases in the rearing potential for chinook in $\mathrm{CR}$.

We estimated the $C R$ chinook parr abundance in 1988 to be $60,509 \pm 19,831$. If the 200,100 fry stocked in 1988 survived to the parr stage at a rate of 20\% (Scully et al. 1990), approximately 40,000 of this total would have resulted directly from supplementation and approximately 20,500 from natural spawning. Based on the natural egg deposition of 108,000 (Table 13), these estimates and assumptions imply an egg-to-parr survival rate of $19 \%$ for brood year 1987 . If the outplanted fry survived at a rate of 15\%, natural egg-to-parr survival would be $28 \%$.

Steelhead parr densities were similar in 1986, 1987, and 1988 and lower in 1984 and 1985 (Table 17). In 1985, approximately three times as many adult females (1,522) were outplanted into CR than in 1987 (468) (Table 15), yet they did not produce higher parr densities in CR. If we assume that natural escapement was low during this period, then it appears that 500 or fewer adult female hatchery steelhead could fully seed CR. The lower steelhead parr density in 1984 and 1985 were probably a result of low natural escapement and the lack of supplementation for brood years 1983 and 1984.

We estimated the $\mathrm{CR}$ steelhead parr abundance in 1988 to be $22,522 \pm 4,046$ age-1+ and 1,798 \pm 958 age-2+. Pending the completion of the CR trap and weir in 1990, no estimates can be made for natural steelhead escapement, egg deposition, or egg-to-parr survival rate.

\section{PIT Taqqing}

We PIT-tagged chinook and steelhead parr in CR from August 2-9, 1988. During the first four days, we tagged cooperatively with a NMFS crew headed by Steve Achord and targeted on chinook. For the last four days, the IDFG crew targeted on steelhead. We tagged a total of 3,717 chinook and steelhead parr, with an overall mortality of $0.8 \%$ (Table 18). This overall mortality was higher than observed in USR $(0.4 \%)$ but still below our defined acceptable level of $5 \%$

We conducted six 24-h delayed-mortality tests of PIT-tagged parr from CR in 1988. We observed delayed mortalities of $1.2 \%$ for chinook and $6.5 \%$ for steelhead (Table 19). Although the number of steelhead that died was small (5), the relatively high delayed mortality indicated that there may be a problem and will be investigated further.

Length and weight were measured on PIT-tagged parr. The average length of chinook parr was similar among strata (Table 20). The average length of chinook parr from CR $(69 \mathrm{~mm})$ was smaller than those from USR $(76 \mathrm{~mm})$. The average length of steelhead ranged from $95 \mathrm{~mm}$ in lower CR (stratum 5) to $123 \mathrm{~mm}$ in the canyon. The overall average length of $\mathrm{CR}$ steelhead parr (111 mm) was smaller than those from USR (138 mm). 

Table 17. Density (number/100 $\mathrm{m}^{2}$ ) of age-l/age-2+ steelhead parr
for CR, 1984-1988.

\begin{tabular}{|c|c|c|c|c|c|}
\hline $\begin{array}{l}\text { Stream, } \\
\text { Stratum }\end{array}$ & 1984 & 1985 & 1986 & 1987 & 1988 \\
\hline Headwaters & & & & & \\
\hline I & $0.45^{\mathrm{a}}$ & $1.00^{\mathrm{a}}$ & $6.80 / 0.17$ & $4.27 / 0.70$ & $5.21 / 0.15$ \\
\hline II & & $2.05^{\mathrm{a}}$ & $11.67 / 1.07$ & $10.82 / 3.74$ & $8.82 / 0.38$ \\
\hline Canyon & & & & & $11.44 / 1.16$ \\
\hline III & $3.10^{a}$ & & $6.20 / 0.20$ & $6.09 / 2.82$ & $10.32 / 0.50$ \\
\hline IV & $0.70^{\mathrm{a}}$ & $0.25^{\mathrm{a}}$ & $7.15 / 0.30$ & $7.24 / 1.49$ & $7.15 / 1.12$ \\
\hline Relief Creek & & & & & $19.01 / 0.55$ \\
\hline $\begin{array}{l}\text { Connected } \\
\text { Ponds }\end{array}$ & & & $4.73 / 0.33$ & $42.40 / 4.80$ & $17.84 / 1.66$ \\
\hline
\end{tabular}

${ }^{\mathrm{a}}$ Steelhead age-1 and $\mathbf{- 2 +}$ are combined. 
Table 18. PIT tagging mortalities for CR, summer 1988.

\begin{tabular}{lrrr}
\hline & Chinook & Steelhead & Total \\
\hline Number tagged & 2,481 & 1,236 & 3,717 \\
Collecting mortality & & & \\
Number & 7 & 3 & 10 \\
Percent & $0.3 \%$ & $0.2 \%$ & $0.3 \%$ \\
Tagging mortality & & & \\
Number & 11 & 10 & 21 \\
Percent & $0.4 \%$ & $0.8 \%$ & 31 \\
Total mortality & 18 & 13 & $0.8 \%$ \\
Number & $0.7 \%$ & $1.1 \%$ & \\
Percent & & & \\
& & & \\
\hline
\end{tabular}


Table 19. 1988 twenty-four hour delayed mortality test results for $C R$.

\begin{tabular}{|c|c|c|c|c|}
\hline Tag site & $\begin{array}{c}\text { Collection } \\
\text { method }\end{array}$ & $\begin{array}{c}\text { Number } \\
\text { held }\end{array}$ & $\begin{array}{c}\text { Number } \\
\text { mortalities }\end{array}$ & $\begin{array}{c}\frac{\circ}{0} \\
\text { mortality }\end{array}$ \\
\hline & \multicolumn{4}{|c|}{$\underline{\text { Chinook }}$} \\
\hline Pond U (II) & Seine & 128 & 2 & $1.5 \%$ \\
\hline Sill Log B (I) & Shock & 92 & 1 & $1.0 \%$ \\
\hline Natural 1 (I) & Seine & 75 & 1 & $1.3 \%$ \\
\hline Relief CR 1 & Shock & 17 & 0 & $0 \%$ \\
\hline Total & Seine & 203 & 3 & $1.4 \%$ \\
\hline Total & Shock & 109 & 1 & $1.0 \%$ \\
\hline $\begin{array}{l}\text { Overall } \\
\text { totals }\end{array}$ & & 312 & 4 & $1.2 \%$ \\
\hline & & Stee & & \\
\hline Pond U (II) & Seine & 28 & 3 & $10.7 \%$ \\
\hline Sill Log B (I) & Shock & 28 & 1 & $3.6 \%$ \\
\hline Natural 1 (I) & Seine & 5 & 0 & $0 \%$ \\
\hline Relief CR 1 & Shock & 116 & 1 & $0.8 \%$ \\
\hline Total & Seine & 33 & 3 & $9.1 \%$ \\
\hline Total & Shock & 144 & 2 & $2.2 \%$ \\
\hline $\begin{array}{l}\text { Overall } \\
\text { totals }\end{array}$ & & 177 & 5 & $6.5 \%$ \\
\hline
\end{tabular}


Table 20. 1988 average lengths of PIT-tagged parr from CR.

\begin{tabular}{cccccc}
\hline & \multicolumn{2}{c}{ Chinook } & & \multicolumn{2}{c}{ Steelhead } \\
\cline { 2 - 3 } \cline { 5 - 5 } Stratum & $\begin{array}{c}\text { Number } \\
\text { tassed }\end{array}$ & $\begin{array}{c}\text { Mean } \\
\text { FL }\end{array}$ & & $\begin{array}{c}\text { Number } \\
\text { tassed }\end{array}$ & $\begin{array}{c}\text { Mean } \\
\text { FL }\end{array}$ \\
\hline I & 1,007 & 69 & & 299 \\
II & 431 & 67 & 532 & 115 \\
CAN & 2 & 95 & 146 & 107 \\
RC & 0 & & 157 & 123 \\
III & 696 & 68 & 76 & 113 \\
IV & 342 & 70 & 26 & 95 \\
\end{tabular}




\section{Outmiqration Trapping}

Outmigration trapping at CR began in fall 1988. A modified Krey-Meekin trap was operated continuously from September S-October 30, except for September 12 when a mechanical failure took the trap out of operation. We trapped a total of 6,778 chinook parr, had a chinook trapping efficiency of $53.7 \%$, and a total chinook run estimate of 12,620. For steelhead age.1+ and $\mathbf{- 2 +}$ the numbers were, 187 trapped, a trapping efficiency of 27.5\%, and a total run estimate of 690 . The proportions of summer parr populations that outmigrated in the fall were $20.9 \%$ for chinook and $2.8 \%$ for age.l+ steelhead. The magnitudes of the fall outmigrations in 1988 for both species from CR were smaller than those from USR (63.7\% chinook and 48.1\% age.1+ steelhead). These data support the hypothesis that higher elevation and harsher climate streams will have a higher percentage of the parr outmigrating in the fall to overwinter in downstream areas. Results to date also suggest that a higher percentage of chinook parr outmigrate in the fall than steelhead parr.

Unlike the daily run estimates for USR, there were several days for CR in 1988 that peaks in the steelhead outmigration did not coincide with peaks in the chinook outmigration (Figure 13). Approximately one-third of the entire chinook fall outmigration occurred on one day (October 9). The major peak in the chinook outmigration occurred on a day with a moderate drop in temperature (Figure 14) and four days before a major storm event (Figure 15).

\section{Dam Detections}

The first dam detections from CR PIT-tagged parr occurred in spring 1989, and will be summarized in the FY 1989 report.

\section{RECOMMENDATIONS}

We recommend a prompt resolution to the USR dewatering problem at the S45 and ALC diversions. Resolution of the dewatering problem would result in a significant increase in the smolt production potential of the USR. Adult chinook passage into headwater areas would be assured in all years. Egg-to-Parr survival upstream of the diversion in low gradient headwater streams appears to be much greater than below the diversion. PIT tag data showed that the parr-to-smolt mortality was three to four times greater for chinook and steelhead parr rearing above the diversion. We believe this additional parr mortality occurred in the fall when approximately 65\% of the chinook parr and $50 \%$ of the steelhead parr attempted migration and encountered the dewatered conditions below these diversions. Resolution of the dewatering would improve adult chinook passage into the USR headwaters where higher egg-to-parr survival occurs, and improve the parr-to-smolt survival for both chinook and steelhead. 


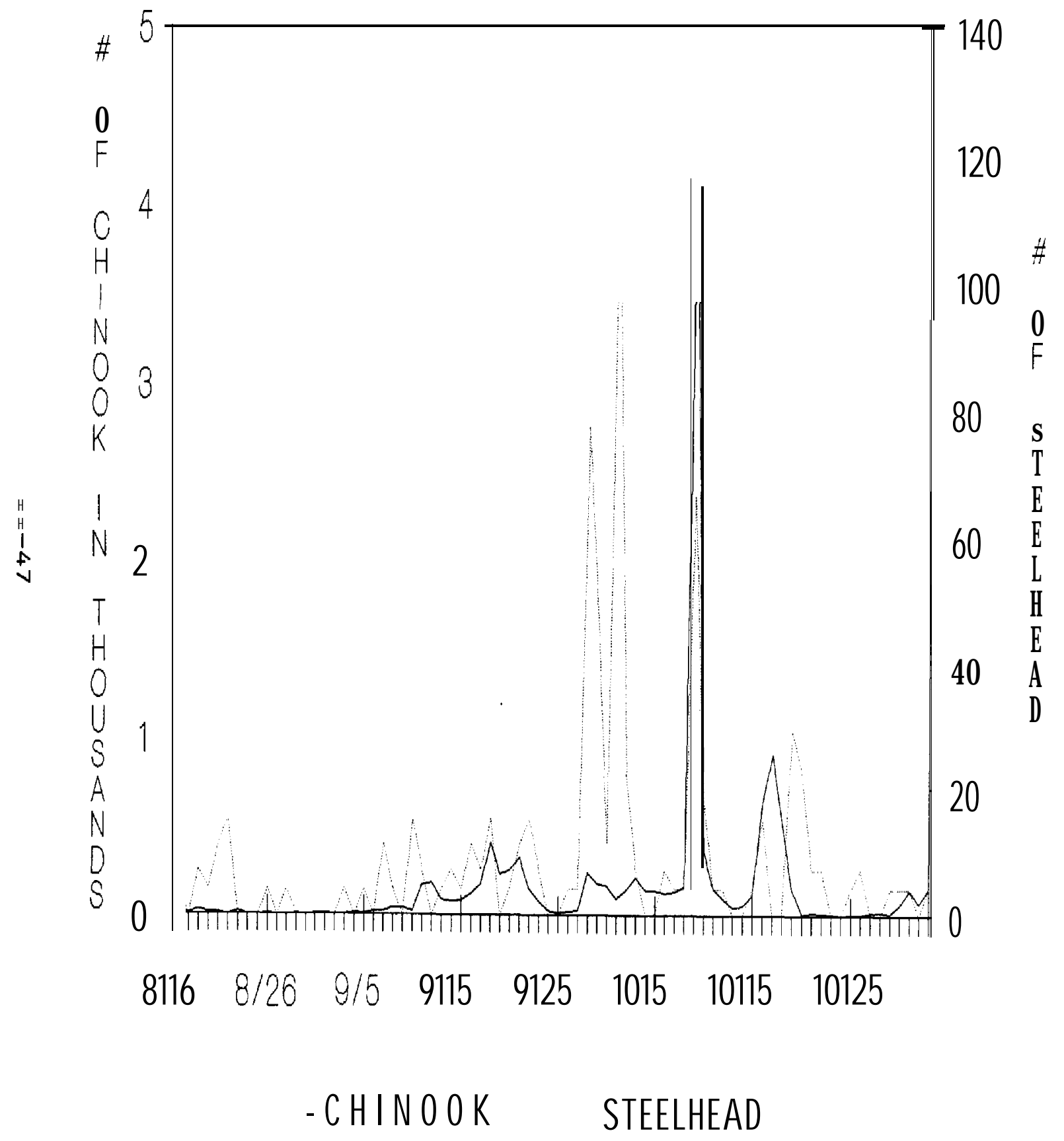

Figure 13. Fal1 1988 CR outmigration run estimates. 


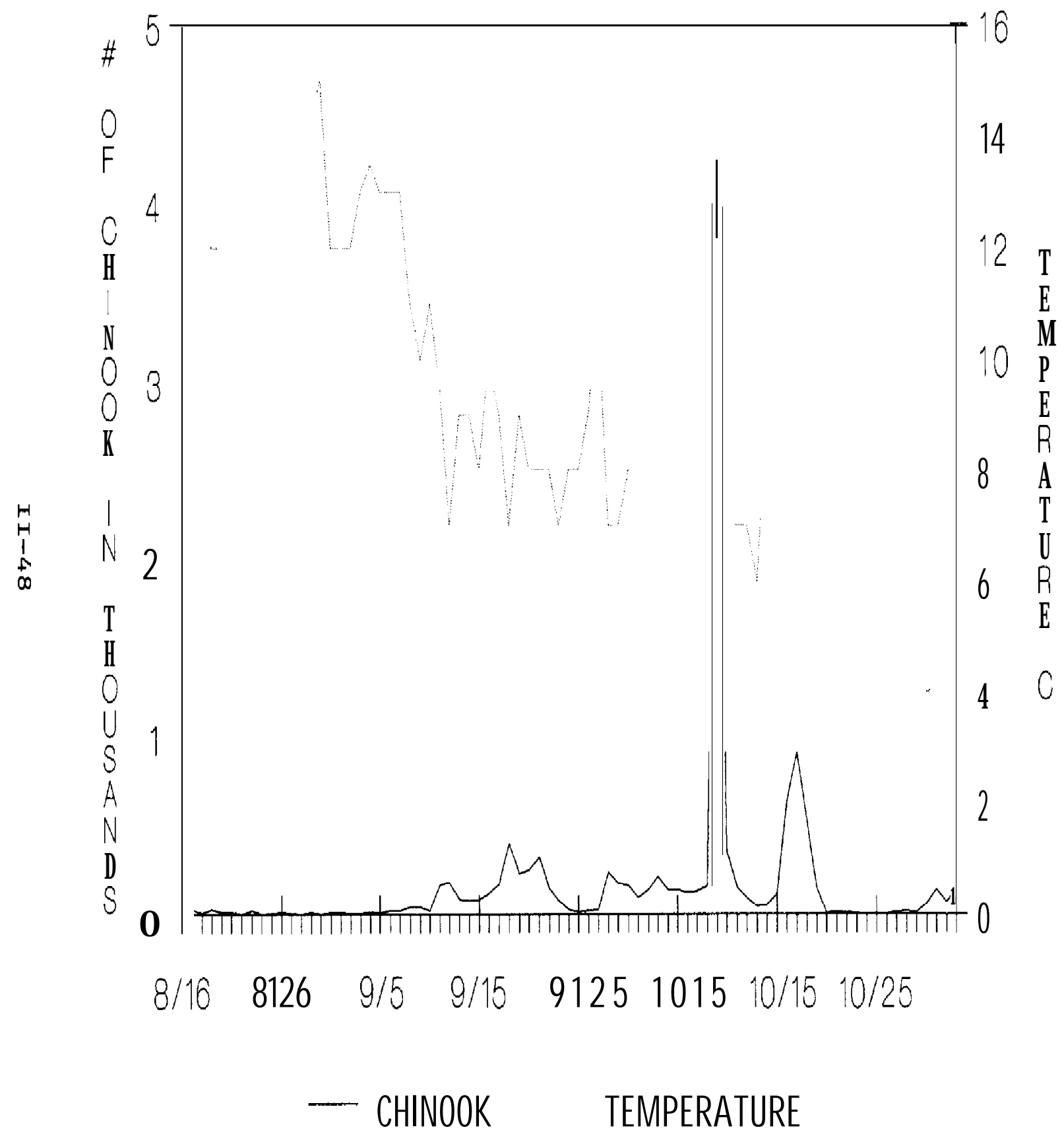

Figure 4. Fall 1988 CR chinook run estimates and daily (10:00 am) water temperature. 


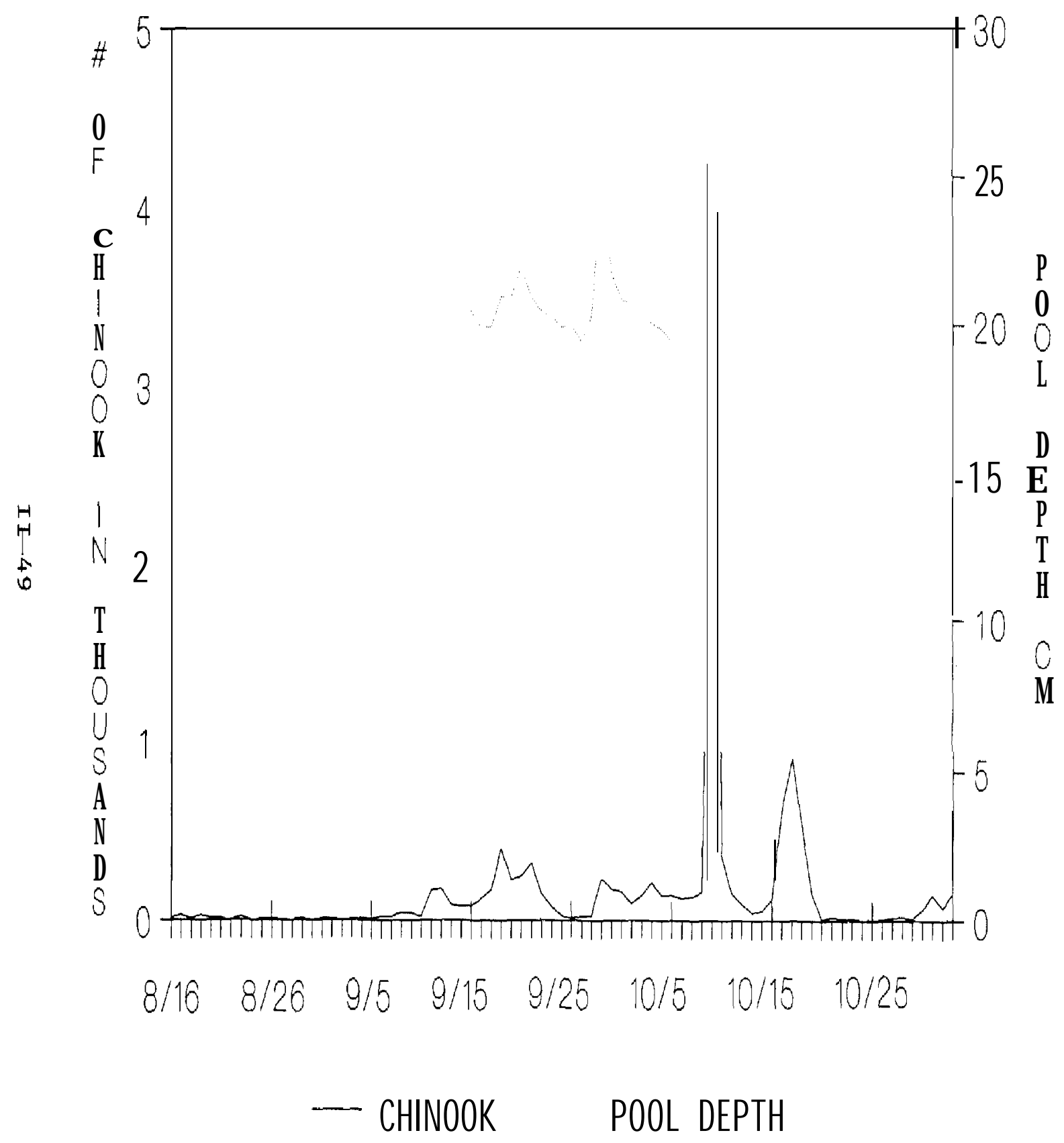

Figure 15. Fa11 $1988 \mathrm{CR}$ chinook run estimate and pool depth reading, 
We also recommend further instream flow improvement in Pole Creek. One possible solution would be to find an alternative power source for the sprinkler system and return to the stream water that is now used to power the system. During low water years, the water temperature in Pole Creek rises above levels optimal for salmonids in the reach from the diversion to the discharge point for the water used to power the sprinkler system. Most salmonids moved out of this area in 1988 to avoid the high temperatures, and those that stayed suffered from reduced growth rates.

We recommend for streams severely degraded by dredge mining, such as $\mathrm{CR}$, that development of off-channel ponds be prioritized in rehabilitation projects. Parr density data from $\mathrm{CR}$ indicate that the chinook rearing potential can be increased significantly through connection of off-channel ponds.

Better definition of steelhead age and size at smolting is necessary to interpret PIT tag dam detections and to estimate parr-to-smolt survival in Idaho streams. The dam PIT tag detection data indicate that only steelhead larger than $130 \mathrm{~mm}$ (presumably age-2+) successfully smolt. 


\section{LITERATURE CITED}

Bjornn, T.C. 1978. Survival, production, and yield of trout and chinook salmon in the Lemhi River, Idaho. University of Idaho, Forest, Wildlife, and Range Experiment Station, Completion Report, Project B-036-IDA, Moscow, Idaho.

Bowles, E.C. and T. Cochnauer. 1984. Potential sockeye salmon production in Alturas Lake Creek drainage, Idaho. Idaho Department of Fish and Game, prepared for U.S. Department of Agriculture, Forest Service, Sawtooth National Forest.

Buell, J.W. 1986. Stream habitat enhancement evaluation workshop: a synthesis of views. U.S. Department of Energy, Bonneville Power Administration, Division of Fish and Wildlife, Portland, Oregon.

Chapman, D.W. 1988. Critical review of variables used to define effects of fines in redds of large salmonids. Transactions of the American Fisheries Society. 117:1-21, 1988 .

Emmett, W.W. 1975. The channels and waters of the upper Salmon River area, Idaho. U.S. Geological Survey Professional Paper 870 - A.

Everman, B.W. 1895. A preliminary report upon salmon investigations in Idaho in 1894. Bulletin U.S. Fish Commission 15:253-28

Goldstein, R.M. 1978. Quantitative comparison of seining and underwater observation for stream fishery surveys. Progressive Fish-Culturist $40(3): 108-111$.

Hair, D. and R. Stowell. 1986. South Fork Clearwater River habitat enhancement. Annual Report. Department of Energy, Bonneville Power Administration, Division of Fish and Wildlife, Portland, Oregon.

Hall-Griswold, J. and T. Cochnauer. 1988. Salmon and steelhead investigations, Study 1, Salmon spawning ground survey. Federal Aid in Fish Restoration, Job Performance Report, Project F-73-R-10. Idaho Department of Fish and Game.

Idaho Department of Fish and Game. 1987. Redd Count Manual. Idaho Department of Fish and Game.

Idaho Department of Fish and Game. 1985. Idaho anadromous fish management plan, 1985-1990. Idaho Department of Fish and Game.

Kiefer. R, and K. Apperson. 1987. Intensive Evaluation Monitoring of Chinook Salmon and Steelhead Trout Production, Crooked River and upper Salmon River sites. Annual Report. Department of Energy, Bonneville Power Administration, Division of Fish and Wildlife, Portland, Oregon. 
Mallet, J. 1974. Long range planning for salmon and steelhead in Idaho. Job 2: Inventory of salmon and steelhead resources, habitat, use, and demand. Job Performance Report, Project F-58-R-1, Idaho Department of Fish and Game.

Mann, H., and M. Von Lindern. 1987. Water Quality Status Report No. 80. Crooked River, Idaho County, Idaho. Idaho department of Health and Welfare. Water Quality Bureau.

Nelson, L. and E. Buettner. 1989. Smolt Condition and Timing of arrival at Lower Granite Reservoir. Annual Report on Operations. Idaho Department of Fish and Game.

Buettner, E.W. and L. Nelson. 1988. Smolt condition and timing of arrival at Lower Granite Reservoir. Annual report on operations. Idaho Department of Fish and Game.

Ortman, D.W. 1968. Salmon and steelhead investigations, Job 1, Southfork of the Salmon River, salmon and steelhead harvest and escapement studies. Federal Aid in Fish Restoration, Job Completion Report, Project F-49-4-6. Idaho Department of Fish and Game.

Petrosky, C.E., and T.B. Holubetz. 1985. Idaho habitat evaluation for off-site mitigation record, Annual report, 1984. Idaho Department of Fish and Game for U.S. Department of Energy, Bonneville Power Administration, Division of Fish and Wildlife, Portland, Oregon.

Petrosky, C.E. and T.B. Holubetz. 1986. Idaho habitat evaluation for off-site mitigation record, Annual report, 1985. Idaho Department of Fish and Game for U.S. Department of Energy, Bonneville Power Administration, Division of Fish and Wildlife, Portland, Oregon.

Petrosky, C.E. and T.B. Holubetz. 1987. Idaho habitat evaluation for off-site mitigation record, Annual report, 1986. Idaho Department of Fish and Game for U.S. Department of Energy, Bonneville Power Administration, Division of Fish and Wildlife, Portland, Oregon.

Petrosky, C.E. and T.B. Holubetz. 1988. Idaho habitat evaluation for off-site mitigation record, Annual report, 1987. Idaho Department of Fish and Game for U.S. Department of Energy, Bonneville Power Administration, Division of Fish and Wildlife, Portland, Oregon.

Platts, W.S., W.F. Megahan, and G.W. Minshall. 1983. Methods for evaluating stream, riparian, and biotic conditions. U.S. Department of Agriculture, GTR INT-138.

Prentice, E.F., D.L. Park, T.A. Flag, and C.S. McCutcheon. 1986. A study to determine the biological feasibility of a new tagging system: 1985-1986. National Marine Fisheries Service, Northwest and Alaska Fisheries Center, Seattle, Washington. Bonneville Power Administration Contract Number DEA179-84BP11982, Project Number 83-319. 
Rosgen, D.L. 1985. A stream classification system. North American Riparian Conference, Tuscon, Arizona, April 16-18, 1985.

Schaeffer, R.L.; Mendenhall, W.; Ott,L. 1979. Elementary survey sampling. 2d ed. Boston: Duxbury Press; 1979. 278p.

Scully, R.J., E.J. Leitzinger, and C.E. Petrosky. 1990. Idaho Habitat Evaluation for off-site mitigation record, Annual report, 1988. Idaho Department of Fish and Game for U.S. Department of Energy, Bonneville Power Administration, Division of Fish and Wildlife, Portland, Oregon.

Shepard, B.B. 1983. Evaluation of a combined Methodology for estimating fish abundance and lotic habitat in Mountain streams of Idaho. Masters Thesis, University of Idaho, Moscow, Idaho.

Thurow, R.F. 1985. Middle Fork Salmon River fisheries investigations. Idaho Department of Fish and Game, Project F-73-R-6. Idaho Department of Fish and Game.

Torquemada, R.J. and W.S. Platts. 1988. A comparison of sediment monitoring techniques of potential use in sediment/fish population relationships. Part III in Idaho Department of Fish and Game. 1988. Idaho habitat evaluation for offsite mitigation record, Annual Report, fiscal year 1987. Department of Energy, Bonneville Power Administration, Division of Fish and Wildlife.

White, L.E. 1980. Evaluation of a new planting device for salmon eggs. Progressive Fish-Culturist 42(3):177-180. 